\title{
The institutional politics of the European Union : an analysis of administrative governance and constitutional reform in the EU
}

Citation for published version (APA):

Christiansen, T. (2008). The institutional politics of the European Union : an analysis of administrative governance and constitutional reform in the EU. [Doctoral Thesis, Maastricht University]. Maastricht University. https://doi.org/10.26481/dis.20080215tc

Document status and date:

Published: 01/01/2008

DOI:

$10.26481 /$ dis.20080215tc

Document Version:

Publisher's PDF, also known as Version of record

Please check the document version of this publication:

- A submitted manuscript is the version of the article upon submission and before peer-review. There can be important differences between the submitted version and the official published version of record.

People interested in the research are advised to contact the author for the final version of the publication, or visit the DOI to the publisher's website.

- The final author version and the galley proof are versions of the publication after peer review.

- The final published version features the final layout of the paper including the volume, issue and page numbers.

Link to publication

\footnotetext{
General rights rights.

- You may freely distribute the URL identifying the publication in the public portal. please follow below link for the End User Agreement:

www.umlib.nl/taverne-license

Take down policy

If you believe that this document breaches copyright please contact us at:

repository@maastrichtuniversity.nl

providing details and we will investigate your claim.
}

Copyright and moral rights for the publications made accessible in the public portal are retained by the authors and/or other copyright owners and it is a condition of accessing publications that users recognise and abide by the legal requirements associated with these

- Users may download and print one copy of any publication from the public portal for the purpose of private study or research.

- You may not further distribute the material or use it for any profit-making activity or commercial gain

If the publication is distributed under the terms of Article $25 \mathrm{fa}$ of the Dutch Copyright Act, indicated by the "Taverne" license above, 


\title{
The Institutional Politics of THE EUROPEAN UNION
}

\author{
An Analysis of Administrative Governance \\ and Constitutional Reform in the EU
}

Thomas Christiansen 
Meinen Eltern 


\title{
The Institutional Politics of the EUROPEAN UNION
}

\author{
An Analysis of Administrative Governance \\ and Constitutional Reform in the EU
}

\author{
Proefschrift \\ ter verkrijging van de graad van doctor aan de \\ Universiteit Maastricht \\ op gezag van de Rector Magnificus \\ Prof. Mr. G.P.M.F. Mols \\ volgens het besluit van het College van Decanen \\ in het openbaar te verdedigen op \\ vrijdag 15 februari 2008 om 12.00 uur \\ door
}

Thomas Christiansen 


\section{PROMOTOR}

PROF.DR. T. BLOM

\section{BEOORDELINGSCOMMISSIE}

PROF.DR. H. SCHNEIDER, VOORZITTER

PROF.Dr. K-E. JøRGENSEN (UNIVERSITY OF AARHUS)

PROF.DR. J. RICHARDSON (UNIVERSITY OF OXFORD)

DR. S. VANHOONACKER

PROF.DR. R. DE WILDE 


\section{Acknowledgements}

This volume brings together articles and papers written over a period spanning some 10 years - a long time even by academic standards. My desire to study the institutional politics of the EU began when I joined a research project directed by Jeremy Richardson at the University of Essex in 1995. Thanks to Jeremy's professional guidance as much as his infectious dynamism, my time in Essex was not only productive, but above all instructive: it was an ideal opportunity for an apprenticeship in the processes of academic research and publishing.

If I am grateful for Jeremy to have launched my academic career, then I am also thankful to Tannelie Blom who, from the moment I arrived in Maastricht, supported the idea of submitting these 'collected works' as a $\mathrm{PhD}$ thesis. He kindly agreed, without hesitation, to become my 'promotor', and with gentle pressure and much helpful advice guided me towards the defence of this thesis. Christine Neuhold and Sophie Vanhoonacker have also been immensely supportive during this period, and it is largely because of them that I always felt at home in the Department of Political Science at Maastricht University.

It has been a long and winding road from Essex to Limburg, but fortunately not one that I had to travel alone. There have been a number of important influences that have shaped my thinking over time. I would like to mention, in particular, Knud Erik Jørgensen, who I first met at the European University Institute in Florence, and who has been a mentor, collaborator and friend whose intellect and professionalism I 
will always admire; Emil Kirchner, who trusted me from the start, and from whom I have learned enormously over the years; and Christine Reh, who has been an inspiration from the first moment we met in Bruges - it has been a privilege to be her co-author, and even more so to be friends.

While the chapters in this book are all single-authored, academic work is often teamwork, and beyond those already mentioned I have had the opportunity to work together with a large number of respected colleagues, all of which have contributed to my thinking and my understanding of the institutional politics of the European Union. Amy Verdun, Antje Wiener, Simona Piattoni, Torbjørn Larsson, Beatrice Vaccari, Sonia Piedrafita, Manuela Alfe, Simon Duke, Susana Borras, Ben Tonra, Gerda Falkner, Derek Beach, Mark Gray, Edward Best, Morten Egeberg, Ulf Sverdrup, Jarle Trondal, Mark Rhinard, Andy Smith, Renaud Dehousse, Michael Kaeding, and Pamela Lintner are the names of those that immediately spring to mind.

When putting together the final manuscript of this book in 2007, I spent a few months at the ARENA Centre for European Studies at the University of Oslo, and my thanks go to Morten Egeberg and his colleagues for the invitation, the hospitality and the inspiration which I received from them. Back at EIPA in Maastricht, Johanna Oettel, with her customary efficiency and professionalism, has been a great help in the final stages of editing the manuscript.

For me, the success of academic work depends on contentment at home, and it is therefore no coincidence that this long-lasting project has finally come to a conclusion as Young-ah has come into my life (and become my wife!). She has given me more happiness than I could ever have hoped for, and I am immensely grateful for her support in the final months of completing this thesis. 
Above all, this is a moment to acknowledge the tremendous debt that I owe to my parents - without their love, their support and their faith in my abilities I could never have succeeded in my studies or in my career. It is almost a year now that I lost, totally unexpected, my father, and my greatest regret when defending this thesis is that he, whom I owe so much, cannot be there. All the more I am grateful that my mother will join us on the day and can therefore receive the heartfelt thanks that are due to both of my parents. I dedicate this book to them.

Thomas Christiansen

Maastricht, January 2008 



\section{Table of Contents}

Introduction $\quad 15$

\section{Chapter 1}

The Evolution of Institutional Structures in the European

Union: The Longue Durée of European Integration

Chapter 2

The European Commission

\section{Chapter 3}

The Council of Ministers

\section{Chapter 4}

Analysing the institutional politics of the European

Union: politicised bureaucracy and multiple accountability

\section{Chapter 5}

The General Secretariat of the Council of Ministers

\section{Chapter 6}

Intra-institutional politics and inter-institutional relations in the EU

\section{Chapter 7}

The Role of Supranational Institutions in EU Treaty Reform

\section{Chapter 8}

The Process of EU Treaty Reform: Constitutionalising the European Union

Conclusion 


\section{Remarks}

This thesis is based on the following, previously published articles:

Chapter $\mathbf{1}$ is based on the previously published 'Bringing Process Back In: The Longue Durée of European Integration', Journal of European Integration, Vol.21, No.1 (1998), pp.99-121.

Chapter $\mathbf{2}$ is based on the previously published 'The European Commission: The European executive between continuity and change', in J.J.Richardson (ed.), The European Union: Power and Policy-making 3rd. ed. (London: Routledge, 2005).

Chapter $\mathbf{3}$ is based on the previously published 'The Council of Ministers: Facilitating interaction and developing actorness in the EU', in J.J.Richardson (ed.), The European Union: Power and Policy-making 3rd. ed. (London: Routledge, 2005).

Chapter $\mathbf{4}$ is based on the previously published 'Tensions of European governance: politicised bureaucracy and multiple accountability in the European Commission', Journal of European Public Policy, Vol.4, No.1 (1997), pp.73-90.

Chapter 5 is based on the previously published 'Out of the Shadows: The General Secretariat of the Council of Ministers', in M.P.van Schendelen and R.Scully (eds) Unelected Legislators in the European Union, Special Issue of the Journal of Legislative Studies Vol.8, No.4 (2002). 
Chapter 6 is based on the previously published 'Intrainstitutional politics and inter-institutional relations in the EU: Towards coherent governance?', Journal of European Public Policy, Vol.8, No.5 (2001).

Chapter 7 is based on the previously published 'The Role of Supranational Institutions in EU Treaty Reform', Journal of European Public Policy, Vol.9, No.1 (2002).

Chapter $\mathbf{8}$ is an original chapter, building on previous and ongoing research that will be published in a book, coauthored with C.Reh, Constitutionalising the European Union (London: Palgrave Macmillan, forthcoming in 2008). 



\section{Introduction}

\section{Understanding the Institutional Politics of the European Union}

The defining characteristic of the European Union, it can be argued, are its institutions. It has been through the creation, development and growth of a set of unique institutions that it has become possible to establish supranational governance at the European level. Everything else that matters in the European Union - the interaction of national and European actors, the design of policies, the creation of a system of laws, the preferences of member states - is not only related to, but largely also dependent on the way in which the EU institutions work. The study of European integration is therefore inevitably a study of institutionalisation, and of the peculiar institutional politics that this process has engendered. This collection of articles approaches the study of the European institutions and their politics from a particular perspective - a perspective that recognises that the institutional politics of the Union are closely tied to the process of integration. Institutional political in the European Union are therefore seen in the wider context of the integration process, and hence also in the context of the 
theoretical and meta-theoretical debates that have surrounded the study of European integration.

Starting from the recognition of a close linkage between the wider process of European integration and the institutional politics therefore requires an understanding of the nature of the integration process and the role that institutions play in this process. Such a contextual study of EU institutional politics seeks to bring together the generic insights from the study of institutions in such areas such as comparative politics, organisational theory, public administration and international relations with the particularities that supranational institutionalisation at the European level brings with it. This implies also that - rather than applying standard models of the study of institutions we need to examine the degree to which EU institutions require the development of new approaches in order to account for the specific and potentially unique environment in which they have been established and in which they now operate.

In the current volume, such an understanding for the particular environment of EU institutional politics is developed in chapter 1 . In line with the objective of understanding both integration and institutionalisation as process, the emphasis here is on studying the nature of change (and continuity) in the context of European integration. The approach developed here seeks to 'unpack' integration as a process by distinguishing between a number of different layers of change. Integration is conceptualised as a process that implies the potential of dynamic change at a number of different levels or layers: first, with respect to the making of policies and the effects that this has in terms of legislative and other output. If public action is about changing conditions 'on the ground', then the immediate objective of European integration has also been to achieve 
such results, be it the completion of a single market, or the creation of a single currency, or indeed the aspirations to making Europe a more competitive economy through instruments such as the Lisbon Strategy.

A second layer of change is identified in terms of the deeper institutional changes and adaptations that have occurred in Europe, both as a direct result of institutional choices and as a result of the indirect consequences of other processes, including the 'everyday' policy-process described above. This 'layer of change', termed here 'constitutional reform', occurs both at the European and at the national level (and indeed also at the subnational level) and involves the changes in the institutional structures through which policy- and legislative decisions are made. They are deemed to be 'constitutional' because such change is the result of extraordinary developments - constitutional change is relatively slow but, if and when it happens, results in a more fundamental overhaul of the institutional structure of the polity.

Finally, a third type of change is termed 'structural transformation' and identifies deep changes in the structure of society and politics in Europe. It is not really the outcome of any conscious or deliberate political act (even if such outcomes coincide with the visions of political thinkers or other actors) but rather results from the gradual and underlying changes to the nature of politics over time. It is therefore, by definition, a long-term process that can only be understood through the study of long period of time. Hence, in the context of European integration, this implies a focus at the 'longue duree' in a way that has been established by the Braudel school of historical analysis.

These three layers of change are seen to be parallel process, occurring at the same time and dynamically reinforcing one another. Policy-making impacts on 
institutional design, institutionalisation leads to deeper societal change over time, and the changing structural conditions in turn influence the way in which policies are made, and what impact these have. These are complex processes which need to be investigated in great depth, but the model is presented here mainly in order to provide the context for the study of the EU's institutional politics.

A number of observations are necessary here before taking this further. First, while the conceptualisation of separate layers of change provides for a clear distinction between different kinds of change, the identified layers are only ideal-typical and somewhat artificial. In practice, it will be more accurate to regard the depth of change along a continuum, starting from the very superficial and going to the deeply structural. Second, and following on from this, the movement along this continuum implies a need to shift one's attention from the study of political action to the study of political structure in order to explain change. This sensitivity to the varying degree of analytical relevance of actors and structures has, in turn, significant implications for the study of institutions. Institutional analysis of the kind envisaged here is located towards the centre of the continuum, or, in the context of the framework developed here, institutional reform in the EU occurs at the second layer of change identified above. This means that institutions matter as an object of study in their own right because it is by studying the role and functioning of institutions that we can understand both change and continuity in the process of integration.

Given the title of this study, it is important to define more clearly what is actually meant by 'institution' in this context. The concept of 'institution' is used in rather different ways in the study of the European Union, and indeed there are disciplinary differences between its usage in 
political science, sociology and economics. In particular, there are two different meanings of the concept in use: first, the understanding of 'institution' as a pattern of social norms that shape the behaviour of individuals, creating a sense of predictability of social action. This understanding could be regarded as the structural perspective on institutions: institutions structure the interaction of social actors. However, a second perspective is the view of institutions as organisational units. Such organisations are composed of a (possibly large) number of individuals but these interact under certain conditions - hierarchical relations, clear boundaries, internal cohesiveness - which mean that the organisation as a whole possesses a degree of actorness, indeed that it can be viewed as a (collective) actor.

Both these usages of 'institution', the structural and the organisational, have been in use in the study of the European Union. In the organisational sense, the "EU institutions" are seen as supranational actors and are important, if not crucial to the understanding of the shaping of policies and indeed the integration process as a whole. In the structural sense, institutions in the EU regulate the interaction of a large number of actors on various levels, create expectations about the nature and outcome of these interactions and thus contribute to the permanency of the European construction. In this study, 'institution' is used in both of these understandings, clarifying within the relevant context which meaning is being applied on which occasion.

Having thus located the institutions within a framework of the different layers of change that are encapsulated in the European integration process, one can then move closer to the study of individual institutions themselves. It follows on from the perspective developed here that the temporal dimension is crucial, both at the higher level of abstraction (the different layers of change) 
and from lower levels of abstraction (the study of individual institutions or the relations between them). With respect of the latter that implies the adoption of a historical perspective in the study of institutions. Such a historical perspective, provided by historical and sociological institutionalism, is crucial in order to capture the dual role that institutions play as both agents and structures.

In the study of individual institutions, the approach that is being developed here thus combines insights from both sociological and historical aspects of institutionalisation. It follows the emergence over time of patterns of social interaction among those individuals who are working with or within an institution, the development of rules and norms defining their interaction, and the evolution of an institutional structure based on these rules and norms. Historical institutionalism as an approach is well-equipped in order to confront the puzzle of institutional stability and change. It makes a number of assumptions, however, that have to be spelt out clearly in advance. The first set of assumptions concerns the interaction between structures and agency. Unlike other approaches that give priority, whether explicitly or implicitly, to one or the other ontology, a historical institutionalist approach recognises both structures and actors to be mutually constituted. Actors are to some extent defined by their role within the broader structures within which they work and act, and even though their behaviour is not determined by these structures, their interests and their identity is shaped by it. At the same time, structures, and this includes both legal-institutional and ideational structures, cannot be seen as determining actors behaviour, and even less so decisional outcomes, but instead are themselves subject to change under the behaviour of actors. Denying both actors and structures ontological priority but instead regarding both as mutually constitutive of one another, is what requires us to look at the process of 
interaction. Only over time can it be fully understood how the interaction between structures and agency, and between interests, ideas and identities, pans out. It is on the basis of such a procedural approach that we can then make statements that provide an explanation of institutional evolution.

Such an approach also includes an awareness of the ideas, values and norms that form part of the institutional culture and that contribute to the direction of the institutional environment. Recognition of the role of ideas and norms can also be regarded as being part of a historical institutionalist approach but can also be seen as constituting the core of a separate, sociological institutionalist approach. This sensitivity to (unwritten) cultural norms and values is a key part of the sociological dimension to institutional analysis. Ideas matter in this respect as part of a cognitive map that is being developed in an institution - a 'theory of the institution' about itself which then has consequences for the actions of individual actors.

The empirical challenge of studying institutional politics in the European Union from such a perspective then lies in applying these insights to specific institutions, their internal politics and their 'external' relations. 'EU institutions' clearly is a broad concept in itself, and there is therefore a need to define more clearly the object of study. In the first instance, this involves the main legislative institutions of Commission, Council of Ministers and European Parliament. This is the institutional triangle that is at the heart of EU's institutional dynamics and it consequently is this trio of institutions which has attracted the main part of both academic and political attention. There are, however, other institutions beyond these: the European Court of Justice (together with the Court of First Instance); the Court of Auditors; a number of consultative committees 
(Committee of the Regions, Economic and Social Committee); the European Central Bank in monetary policy; a range of agencies with information-sharing, advisory or regulatory functions in many other sectors. And beyond even this broader definition of European institutions are further institutional forms and mechanisms which also deserve attention. There is, for example, the feature of EU politics which has come to be called 'committee governance' involving committees working with the European Commission in various stages of the policy-making process: expert advisory groups during the initiation phase of $\mathrm{EU}$ policy-making, and so-called comitology committees during the implementation phase. Such committee governance, to which one might also add the committees associated with the Open Method of Coordination (Economic and Financial Committee, Social Protection Committee, Employment Committee), are instances of the institutionalised cooperation between national and European administration something that can be seen as an example of the "fusion" of administrations on different levels in the EU's system of multilevel governance.

As this (still incomplete) list indicates, the institutional politics of the European Union cover a broad ground, requiring a choice to be made in order to conduct more detailed empirical research into processes of institutionalisation. In this volume, a choice has been made to focus, in particular, on the executive branch of the Union's institutional structure. This involves primarily the study of the European Commission, which constitutes the Union's executive branch. But beyond the Commission, also the Council of Ministers and parts of its administration, the General Secretariat of the Council - hereafter called Council Secretariat - has executive responsibilities and will therefore also be examined in contributions to this volume. 
The internal dynamics of both the Commission and the Council are studied from the institutionalist perspective that has been developed above. Once chapter 2 and 3 have provided the background to each of these two institutions, subsequent provide a more detailed analysis of certain aspects of each institution. In Chapter 4 then conceptualises the Commission in a way that links the internal politics of this institution to the dynamics of the wider European Union. The internal politics of the Commission, often regarded as a single actor, are 'unpacked' along two dimensions: the degree of 'decisional rigidity', on the one hand, and the nature of institutional accountability, on the other hand.

The different dimensions of both 'decisional rigidity' (a spectrum ranging from open-ended political bargaining to rule-bound administrative governance) and of 'institutional accountability' - distinguishing between accountability to the states (in the Council) and accountability to the people (represented by the Parliament) - can be brought together in a matrix. Such a matrix provides us with four ideal-typical logics which are in tension in the European Commission: international secretariat; public administration; independent executive agency; and government cabinet. Such a matrix can be seen as a mapping device which not only helps us to understand the internal tensions inside the Commission - and thus the difficulties of managing coordination and achieving coherence in the work of the institution - but which can also be useful in detecting shifts over time. For example, if, at the outset of their institutional life, the European Commission or its predecessor, the High Authority, acted mainly as an international secretariat, then the overall evolution of the Union has moved it towards a politicised bureaucracy. 
This conception of analysing the internal tensions inside the Commission along these two different dimensions therefore provides a mechanism for improving our understanding of the organisational logics that are present on different administrative levels, at different points in time or in the different sectoral sub-units in which the Commission is active. Altogether this provides a more complete picture of the way in which the Commission has evolved and of how it works today - a state of affairs which is illustrated by the competing logics which can be detected through a comparison of the Commission's activity in two different areas of activity, that of state aid control and that of regional policy.

Chapter 5 provides a similar, in-depth look at the internal politics of the Council Secretariat (CS). Other aspects of the administrative system of the Council of Ministers (such as the role of the Presidency and the distinction between the political (European and Ministerial Councils), diplomatic (COREPERs I and II) and technical levels (Council Working Parties), having already been discussed in Chapter 3, the focus is here on the different logics present in the CS. The historical institutionalist perspective adopted here demonstrates the presence of two competing logics present inside the institution: on the one hand, the traditionalist culture of the 'old' secretariat which is essentially legalistic and bureaucratic, involved in the legislative work of the Council - a culture that is perpetuated by an established administrative elite with a strong sense of 'how things are being done' in the Council and in the Union; on the other hand, there is the arrival of the military and diplomatic elites which are not so much tasked with protecting the status quo, but are rather busy establishing something new - the Union's security policy apparatus. Most of the officials who are constituting the 'new' CS are seconded officials from the national administrations bringing 
with them different administrative cultures and lacking the 'Brussels insider' perspective that has been dominant among the staff of the 'old' CS.

The CS has to cope with the tensions arising from this old/new split in the administration at a time as additional pressures arise from the rapid growth of the institution, including the dispersion of the administration across multiple sites, the impact of enlargement, in particular the arrival of staff from the new member states, and the new demands that are placed on the service due to the process of constitutionalisation. The result is an organisation that is, in many ways, experiencing the arrival of the same internal tensions that have been identified in the Commission previously.

The detailed analysis of the internal politics of both Commission and Council Secretariat undertaken in Chapters 4 and 5, respectively, is complemented in Chapter 6 by the study of the external relations between the two institutions. Following on from the study of each institution's internal politics, this provides an opportunity for the systematic analysis of their inter-institutional relations. The key concept introduced here is that of 'inter-institutional coherence' which is defined in terms of the presence of coherent and well-coordinated processes of deliberation and decisionmaking in the relations between the institutions. This emphasis on coherence is juxtaposed with the more traditional concept of the separation of powers which is sometimes used as benchmark in the evaluation of interinstitutional relations.

The examination of Commission-CS relations undertaken here demonstrates that competitive relations between the two institutions result from the way in which the institutional architecture of the Union pitches one against the other in certain respects. However, it also shows that 
there is a considerable amount of common interest and above all a shared identity that stretches across the institutions. These commonalities counter-balance the factors that divide the institutions somewhat. In combination with the internal tensions that have already been discussed, the conclusion is that there is a considerable degree of interinstitutional coherence that is better explained by sociological and cultural factors rather than by the distribution of rational interests across the institutions.

The aim of chapters $2-6$ is to provide a comprehensive picture of the internal workings and interinstitutional relations of the two institutions that together make up the executive branch of the European Union. As such, they demonstrate the value of an analysis that is driven by the insights of historical and sociological institutionalism, with a focus on the way in which rules, norms and cultural values evolve over time and influence both the intra- and inter-institutional politics in the Union.

This is a study meant to identify the dynamics on the second layer of change - that of institutional and constitutional reform in the Union. So far, one important element in this process has been absent: the nature of changes to the treaties which provide the legal framework which provides the foundation for institutional politics in the EU, the EU treaties. Hence, Chapter 7 turns to address this question through an analysis of the way in which both Commission and CS are involved in the treaty reform process.

Whereas in the previous chapters Commission and CS appear as the objects of deeper fault-lines within the integration process - wider tensions in the European Union finding their specific expression in the institutional politics chapter 7 looks at both institutions as actors in the process of treaty reform. Such a perspective is based on a particular 
conception of EU treaty reform, again derived from the recognition that the temporal dimension is crucial in understanding the process of treaty reform. It is from such a procedural perspective that treaty reform appears as more than the bargaining among member states that it often appears in traditional analyses.

In the framework developed and applied here, treaty reform involves not only national actors as part of a 'twolevel game', but also involves EU level actors in a 'two-way process'. While member state actors project their preferences onto the European level, enter a bargaining process and ultimately make decisions about the delegation of powers to European institutions, they are themselves subject to influences from the European level. This has both direct and indirect significance for the nature of the intergovernmental conferences (IGCs) which negotiate treaty change. One channel of influence results from the Commission, CS and EP - all of which are involved in varying ways in the reform process - introducing practices and norms derived from the 'everyday politics' of European integration into the negotiations. In part, these rules provide the institutional frame for the negotiations in the IGC, and such a framework in turn constraints the ability of national actors to act as the sole 'masters of the treaty'. Commission and CS, as well as EP and ECJ, also intervene more directly in treaty reforms. Even if their influence in the decisionmaking phase is limited - they clearly do not act as an additional member state - they nevertheless play an important role in the agenda-setting and in the ratification phase of the treaty reform process.

This study of treaty reform completes the analysis of institutional politics undertaken here. Framed within a wider conception of different layers of change, the focus is on the intermediate level of constitutional reform in the Union, that 
is, the way in which processes of institutionalisation provide for both continuity and change in the integration process. The related studies of Commission and Council Secretariat are being used to illustrate the way in which the sociological and historical institutionalist approach can be used to enhance our understanding of the workings of these institutions, and of their place in the wider architecture of the Union. And the study of treaty reform, in turn, shows the degree to which these institutions are involved in decisions about the evolution of the wider European architecture.

As a study of institutional politics in the European Union this is far from comprehensive: the focus has only been on developments on one of the three layers of change that have initially been identified. A more comprehensive analysis would also need to look at both the layers of the policy-process and the layer of structural transformation. And this volume has concentrated on the analysis of institutional dynamics of the main institutions of the EU's executive branch. In order to have a fuller picture one would need also to study the other branches, and indeed apply this approach also to the other institutional mechanisms identified above.

Nevertheless, the present study proposes a framework for the systematic study of European institutions and therefore goes some way to provide for an understanding of the nature of institutional politics in the European Union. Further studies of the other layers and a wider range of institutions would be required in order to complete the picture. What this present study achieves, it is hoped, is to provide not only a convincing that the EU institutions matter, but also how they function and how their evolution is related to the wider process of integration in Europe. 


\section{Chapter 1}

\section{The Evolution on Institutional Structures in the European Union:}

\section{The Longue Durée of European Integration}

In the 1990s, European integration has become dominated by Intergovernmental Conferences - their preparation, negotiation, ratification and implementation. Due to their increasing frequency, length, scope and intensity, IGCs are now an omnipresent aspect of EU politics, whereas only ten years ago an IGC was regarded as a single and highly exceptional event. As a result, the study of integration has had to grapple with a paradox: on the one hand, the reforms contained in the past three IGCs have massively enhanced the significance of the supranational institutions. On the other hand, the intergovernmentalism inherent in treaty reform has emphasised the hold national actors have on the development of the EU. 
The acceleration of the integration process has spawned renewed interest in the development of integration theory. In particular, the above paradox has revived a debate between those favouring, respectively, supranationalist and intergovernmentalist approaches to the study of integration. Apart from revisions of liberal intergovernmentalism and the revival of neofunctionalism, novel concepts such as multilevel governance, new institutionalism or judicial politics have contributed to this debate. We witness, as a result, the proliferation of theoretical work on the EU, a very welcome development after the earlier dearth of such efforts.

Considering the proliferation and the increasing diversity of integration theory, this articles sets out towards a meta-theoretical mapping of the field. In doing so, it takes a closer look at the ontological grounding of various approaches. In particular, it questions the degree to which integration theory is still concerned with the analysis of process. Considering that the argument between supranational and intergovernmental explanation has revolved around the role of political actors and the study of individual decisions and events, it argues for a broader notion of 'process' as the core of analysis.

The article proceeds in three steps. The first section briefly discusses the dominant ontology of approaches to European integration in two key disciplines, law and political science. The second section deals in more detail with the way in which we can 'bring process back in'. European integration is conceptualised as a process occurring on a number of different levels, which are termed here 'layers of change'. An improved understanding of integration, it is argued, results from an awareness not only of the dynamics of each level, but also from their interconnectedness. The third section discusses how the process of macro-social transformation of Europe - the study of the longue durée of 
integration which has so far been underdeveloped - can be brought into the analysis. Imports from other disciplines into political science are suggested to assist this objective. By way of conclusion, the article suggests that this view of integration as a multi-layered process helps to map the terrain of EU studies, facilitates communication between disciplines and can usefully organise the future development of integration theory.

\section{Disciplinary Boundaries and the Agency/Structure Problem}

For most of the past decades law and political science have charted very different stories of European integration. Legal science has been concerned with the construction, interpretation and development of the edifice of Community Law. Its gradual and seemingly automatic progress has been, to most analysis of European law, a self-referential exercise that, starting from the skeleton of the original Treaties, built up a body of legal doctrine, case law, secondary legislation, administrative procedures and informal rules. Products of this process, such as the principles of primacy, direct effect and mutual recognition, are now key parts of the European legal order. Whether the direction this process has taken is welcomed (Mancini, 1991) or criticised (Rasmussen, 1988), legal science appears to have well established the great lengths to which 'integration through law' has taken the European project.

By contrast, political science views on the progress of integration in the 1970s and 1980s were more muted. After the crisis of neo-functional integration theory in the late 1960 s, analysis concentrated on the 'limits' of integration (Taylor, 1980) and the 'conjunctural' nature of agreement 
among the Member States (Keohane and Hoffmann, 1990). Federalism, as analytical category as much as political project, took to the back-stage. More recently, both neofunctionalism (Tranholm-Mikkelsen, 1991) and federalism (Scharpf, 1994) received renewed attention. Yet, by the early 1990s, the most widely cited theoretical literature still revolved around intergovernmentalist conceptions of integration, emphasising the problematic and contingent nature of the process (Moravcsik, 1991; 1993; 1994a; 1994b).

Consequently, with such different views on the progress of European integration, the legal and political sciences had, for long periods of time, little to exchange on the subject. Often, it was a case of mutual neglect. This is, of course, not the whole story. As Joerges (1995) argues, there are, in both disciplines, parallel approaches and common problems, which make for connecting bridges across the disciplines. Indeed, the past fifteen years have seen impressive advances towards interdisciplinary debate. Weiler's work), identifying the complementary logics of normative and decisional supranationalism, has gone a far way to bring the conflicting conclusions of political and legal analysis together (Weiler, 1981; 1991). Similarly, the discussion of judicial politics in Europe (Stone, 1994) and within the Community legal order (Alter and MeunierAitsahalia, 1994) indicates that there is much merit in the intercourse of the two disciplines. The debate between Garret (1992; 1995), on the one hand, and Burley and Mattli (1993; 1995), on the other, has injected legal scholarship into the traditional debate between neofunctionalism and intergovernmentalism in integration theory.

All this is proof enough that debate - if not synthesis - across disciplinary boundaries is possible and productive. But each discipline's mainstream still remains tied to 
established ways of looking at the subject-matter, at the expense of valuable imports from other fields. if it is recognised that the divergence between legal and political science treatments of the integration process is the consequence of an ontological antagonism: legal science usually proceeds under the assumption that structural factors - the law - are ontologically dominant. Political science work on integration, by contrast, has habitually assumed that actors, their interests and the distribution of power among them are primary. While such assumptions are rarely spelled out explicitly, their influence on empirical research and on the 'facts' it will look at, are highly consequential - as argued by Ruggie in his critique of traditional international relations methods:

How we think about transformation fundamentally shapes what we look for; what we look for obviously has an effect on what we find; if we look for signs of transformation through the lenses of the conventional approach of our discipline we are unlikely to conclude that anything much is happening out there; but we cannot be sure whether or not that conclusion is correct because the epistemological biases of that approach are such that it is ill-equipped to detect signs of transformation.

Such a recognition of the relevance of meta-theory is the underlying rationale of the present argument: it does matter what kind of change we study, and it matters under which ontological and epistemological star the subsequent research is carried out.

The main body of political science literature on European integration has been concentrating on policymaking processes and treaty reform. This concentration on events as opposed to transformation has influenced the results of the respective research agenda: the 'events' of a certain phase of integration are taken to indicate a general 
course of integration, whether, as with the first wave of neofunctionalism, the move towards an ever-more integrated political system, or, as claimed by liberal intergovernmentalism, the continued importance of state interests.

A tendency towards deterministic views on the integration process can be seen as a consequence of the ontological choices implied in studies of this kind. The ontology of any research into the 'event history' of European integration is bound to be based on the primacy of actors over structures, whether these are bureaucratic and business elites (as in neofunctionalism), governmental executives or collective actors such as Member States (as in intergovernmentalism). This does not mean that structures are completely left out of the picture - both neofunctionalism and intergovernmentalism do take structures into account. But agency is, implicitly or explicitly, considered primary actors ultimately determine the shape of overall structures. Consequently, their actions must be regarded as of being of high relevance. Hence the tendency for this kind of studies those concentrating on policy-making and treaty-revision - to rely on the explanation of 'key events' at the expense of considerations for about structural change.

The determinism inherent in studies based on the primacy of either agency or structure has been extensively discussed elsewhere (Wendt, 1987; 1991; 1992; Hollis and Smith, 1991a; 1991b; 1992; Dessler, 1989; Carlsnæs, 1992; Ruggie, 1989). The recognition that meta-theoretical choices like those related to the agency-structure problem are of high relevance for both conceptual work and empirical research has been fuelling major debates in the social sciences. Yet, even though its implications are clearly felt also in the field of European integration, a discussion of meta-theory and of the agency-structure problem have hardly featured there. 


\section{Re-conceptualising the Integration Process: Multiple 'Layers of Change'}

While it is generally accepted that integration is a procedural phenomena, there is little consensus on the time-span that requires analysis. That is precisely why, as demonstrated above, much of the literature has concerned itself with 'event history'. The 'structural depth' of the integration process has generally remained unexplained. While many analyses, in particular those concerned with individual policy-sectors or specific decisions, set out to record limited measures of change, others have been concentrating on a larger scale of transformation. Sometimes, not always, this is the result of concentration on micro- as opposed to macro-analysis of integration.

Judgements about the effects of integration are not necessarily affected by choices of 'structural depth' of the analysis. In other words, the predilection for one or the other scale of analysis does not, in itself, predetermine the outcome. A specific policy-analysis, for example, might come up with the conclusion that something has fundamentally changed in a certain sector of Community activity. Yet the application of the same methods, tools and assumptions to another sector might present quite a different picture, that of no or very little change. Indeed, the turning out of dissimilar and even contradictory results of this kind across different sectors has been the recurring feature of EU policy-analysis.

For our purposes it is useful to distinguish between different layers of change. This is, essentially, the utilisation of Braudel's distinction between longue durée and histoire eventenement (Braudel, 1981) to the study of contemporary European politics. In political science, a similar distinction is found in Downs' study of organisations. He conceptualised change in bureaucracies along four 'organisational layers ... 
of structural depth' (Downs, 1967, pp-167-171). Similarly, but adding the temporal element, a number of scholars have viewed the end of the Cold War in Europe along a number of layers of different depths (Jørgensen, 1995; Wæver, 1993).

Also European integration can be visualised as part of a multi-layered territorial process, as is implied by Allott.

The biological history of present-day Europe is a triple helix of interacting strands: the strand of international relations, the strand of internal national developments, and the strand of European culture, of the European spirit. The European Community is a striking example of an effect produced by the causes in all three strands of the European social process (Allot, 1991, p.2990).

Peterson (1995) has distinguished between three levels of analysis: super-systemic, systemic, sub-systemic. In this conception, the 'super-systemic' is identified as 'historymaking' decisions by national governments in European Councils and ICGs and by the ECJ. The 'systemic' level is constituted by 'policy-setting' decisions in the Council, and the 'sub-systemic' level consists of 'policy-shaping' decisions by Commission and committees (Peterson, 1995, p.71). Such advances demonstrate that the usefulness of a 'layers of change' concept is well recognised as an analytical tool.

Nevertheless, the usage of the concept here is distinct from the above studies in a number of ways. Firstly, it is about conceptualising different modes of analysis rather than real-world events. The point here is not to study the actual process of European integration, but to propose ways of integrating different approaches to that study. Secondly, the differing layers of change are not about the territorial 
reach of integration processes, but about their historical depth.

The conception here suggests three temporal layers of change, as set out in the table below, which are termed as policy-making process, constitutional reform process and macro-social transformation process.

\begin{tabular}{||l||l|l|l|l||}
\hline $\begin{array}{l}\text { Layer of } \\
\text { Change }\end{array}$ & Ontology & $\begin{array}{l}\text { Structural } \\
\text { Depth }\end{array}$ & $\begin{array}{l}\text { Time- } \\
\text { span }\end{array}$ & Scope \\
\hline \hline $\begin{array}{l}\text { Policy-making } \\
\text { process }\end{array}$ & agency & shallow & $\begin{array}{l}\text { months- } \\
\text { years }\end{array}$ & $\begin{array}{l}\text { sector/ } \\
\text { network of } \\
\text { actors }\end{array}$ \\
\hline $\begin{array}{l}\text { constitutional } \\
\text { reform process }\end{array}$ & $\begin{array}{l}\text { agency/ } \\
\text { structure }\end{array}$ & $\begin{array}{l}\text { Inter- } \\
\text { mediate }\end{array}$ & $\begin{array}{l}\text { years- } \\
\text { decades }\end{array}$ & $\begin{array}{l}\text { EU and } \\
\text { national } \\
\text { institutions }\end{array}$ \\
\hline $\begin{array}{l}\text { macro-social } \\
\text { transformation }\end{array}$ & structure & deep & $\begin{array}{l}\text { decades- } \\
\text { centuries }\end{array}$ & $\begin{array}{l}\text { social and } \\
\text { political } \\
\text { structures }\end{array}$ \\
\hline
\end{tabular}

Figure 1: Layers of Change in the European Integration Process

Structural depth is meant to indicate the ontological weight of structure and agency. 'Shallow' here indicates that explanations about change - or the absence of change essentially rely on the study of the strategies and resources of individual or collective actors. Studies of constitutional reform are of 'intermediate' structural depth since they combine elements of agency and structure in the explanation of change. Finally, 'deep', indicates that change is seen to be 
of a structural nature, beyond the influence of individual actors.

Analysing the policy-making processes of the European Community involves the detailed study of individual 'policy-makers', their intentions and resources, the relationships among them - for example the identification of 'policy-networks' or 'epistemic communities' - and to their 'clients' - the business community, associational lobbies, citizens, political parties or affected social groups - and the legal and institutional environment in which they find themselves and which - depending on the results of their (inter)action - might be maintained or changed.

Arguably, the bulk of political science research on European integration in the past twenty years - in the period since the demise of the neofunctionalism - was of this kind. All kinds of sectors touching on Community activity were studied in great depths, bringing to the fore the details involved in the creation of specific, sectoral 'regimes'. Not much of this related to the larger questions about the integration process, mainly because there was little explicit, theoretical effort to do so. But vast literature on policyanalysis was important in that it showed the extent to which EU policy-making has fused previously separate structures. Both horizontally (that is, between interest groups, bureaucrats and political elites) and vertically (between subnational, national and EU-decision-makers) ever-closer links were being built up, while at the same time highly complex regulatory regimes grew within and beyond the legal perimeter of the Treaty.

More recently, both the revival of neofunctionalism and the emergence of a growing body of literature on multilevel governance has been fuelled by the insights received from this multitude of sectoral studies. Constructing and testing theories around the concept of spill-over - integration 
progressing more or less inevitably from one sector to another - requires, first and foremost - an understanding that individual sectors are in fact integrating. Substantiating, or refuting, such an understanding has relied on the insights of EU policy-analysis.

Multilevel governance, as advanced by Marks, Hooghe, Kohler-Koch and others, emerged from the detailed study of one particular area of EU governance: the bargaining over and implementation of the reform of the structural funds (Marks, 1993; Hooghe, 1996; Kohler-Koch, 1996). The conceptualisation of the European Union as a system of non-hierarchical governance has since been generalised to provides one of the main theoretical challenges to the intergovernmentalist approach (Marks et al., 1996; Kohler-Koch, 1997; Stone and Sandholtz, 1997; Jachtenfuchs, 1995; Zürn, 1996).

On the whole, though, policy-analysis has tended to look at individual sectors, often in individual national settings. Opening up theoretical avenues - as in the case of multi-level governance - or conducting genuine comparison between a number of sectors (Héritier, 1997) has remained the exception. Indeed, the growing number of specialised journals for specific EU policy-areas - regional policy, social policy, environmental policy, foreign policy - indicates that policy-analysis continues to proliferate within segmental boundaries.

A layer of change deeper than the policy-process is studied by those analysing what may be called here the process of constitutional reform. There is debate about whether the Treaties and the Community legal order can actually be understood as a 'European Constitution'. Whatever the merits of either view, the idea of constitutional reform - the fundamental change of the meta-rules underlying a legal system - may well be applied well to the 
Union's periodical exercises in treaty reform. This perspective includes the analysis of IGC preparation, domestic interest formation, evolution of national and EU institutional negotiating positions, processes of bargaining and coalition-formation during the Conference, mediation of results to the respective publics and the process of ratification, including possible re-negotiation of draft treaties, within the domestic systems.

There are two phases with a high intensity of constitutional reform in the history of European integration: the mid-1950s and the period from 1985 to the present up to the 1996-7 IGC. Both have spawned a bulk of literature on the dynamics or otherwise of this process. The early phase of integration produced the neofunctionalist research agenda, while recent of IGCs (1986, 1989 I and II, 1996) has led to much debate about the 'liberal institutionalist' approach to integration (Moravcsik, 1993). Equally, the period from the late 1960 s to the early 1980 s with especially low reform intensity led to mainstream literature emphasising the limits of integration (Taylor, 1980; Hoffmann, 1966; 1982)

All these approaches have been concerned with middle-range explanations of European integration. Removed from the everyday life of the Community and therefore from the observation of micro-level change, they have tended to concentrate on the power and interests of member states. Often the argument of such studies has been that the explanation of key events of the integration project, such as, for example, the coming about of the Single Act, must lie at the heart of attempts to theorise about integration. But such analysis implies a bias towards political integration as opposed to functional integration, thus over-emphasising the positions of Member States at the expense of the power that Community institutions and other non-state actors have to influence the course of events (Wincott, 1995). 
On the other hand it is clear that the integration project has, in recent years, become more 'political', and that the difficulties involved in such a move were not properly accounted for in the 'functional' bias of the neofunctionalist project. As the implementation of the essence of Maastricht the creation of a single currency - and the ratification of Amsterdam approaches, this debate is an important one. We stated at the outset the over-riding significance of treaty reform for the current phase of integration. Moreover, as will be argued below, constitutional reform is best seen as the crucial intermediate process which links policy-making to structural transformation.

The dominant view on treaty reform has so far been that the more serious business of integration will attract the more serious attention of the national executives, that this will cause more serious scrutiny of the proposed reform and that agreement will only come about when key Member States' interests are served and can be successfully communicated to the domestic public. This reading of the chances of constitutional reform to move forward the integration process, explains, after all, also the early failure of political integration in the mid-1950s. Consequently, the focus on EU constitutional reform - or its absence - is important and indeed paramount to an overall understanding of the integration project. Yet it can only be understood as a partial explanation of that process. Crucially, as Wincott has argued - this perspective misses the link between the instances of constitutional reform, isolated (in time), and the continuous, 'everyday' business of EU policy-making.

For taking a single instance of EU reform - whether Single Act, Maastricht or Amsterdam - and studying the resultant decisions on the basis Member State preferences must surely miss out on important influences on the crucial question about how national preferences are formed. It is a 
very myopic view of the integration process which perceives the formation and aggregation of interests as a one-way street leading from the national domain to the intergovernmental conference table. Taking into account, as Moravcsik has done, domestic actors - industry, parties, the wider public - in the formation of 'national interests', begs the question as to who or how the preferences of these actors are set.

Answering that question would in many cases refer the analysis of processes towards deeper changes - the changing structural environment which over time has fundamentally redrawn the arenas in which domestic and European actors operate when they make policy or negotiate treaty reforms. It is this missing link, the structural transformation of the Euro-polity, which has so far escaped wider analysis. In much of the agency-dominated literature mentioned above structural change remains either unexamined or enter the stage as an 'externality'. But the transformation of Europe is closely linked to the establishment of the Euro-polity - it is one of the key processes of integration that needs to be studied along side the policy-making and treaty reform processes.

Studying the longue durée of integration therefore goes beyond the modelling of different states' modes of behaviour and opens up to questioning the very nature of the system in which they operate. Ultimately, as far as European integration is concerned, such a look at the longue durée of integration will want to go back in time beyond the actual creation of the EC or ECSC. It will need to look at the evolution of the 'Westphalian state system', the formation of territorial and national states, the conceptual history of key principles such as state sovereignty and national selfdetermination, the development of the idea of European unity, the gradual growth of a framework of rules for cooperation and the changing intensity of communication 
flows. And this is not an exhaustive, merely an indicative list of what the changes we need to study to develop an understanding of what Allott has called 'total history of Europe' (Allott, 1991). But an acknowledgements of the significance of a this 'third layer' for the study of integration does hardly amount to a specific research agenda. This article proposes to move in that direction - indicating the ways of studying the structure of European integration and integrating it with the current body of literature.

The necessity for studying structural transformation is evidenced by a growing body of opinion that sees the developments in Western Europe as a fundamental departure from previous ordering principles. If the European Union is 'less than a federation, [but] more than a regime' (Wallace, 1982), it must be a completely 'novel form of political domination' (Schmitter, 1991). To investigate this rather than to gauge the influence within such a system of individual nation-states - as is the intergovernmentalist design - one needs to go deeper into the structure of European governance and further back in time.

To do so means to question rather than to assume the analytical categories which are traditionally applied to the study of the EU. In this perspective, the crucial questions for inquiry are, first at all about the state. Rather than asking: what do states do or how much influence state actors have in the EU system, we ought to question the nature of the state in Western Europe today. A long-term analysis might demonstrate not only that the 'national interest' of even the more powerful states in Western Europe has fundamentally changed as a result of decades of integration. Also the very identity of the state - of each individual state as well as of the concept as such - is clearly as stake in the course of integration. If statehood has been characterised as territorially delimited government, EU member states are hardly in the 
business of governing 'their' territory any more. In essence they are probably much better understood as channels of interest representation, endowing actors tied into supra- and transnational decision-processes with resources and legitimacy. In studying integration, therefore, it might make better analytical sense to emphasise the membership, not the statehood, of EU member states.

The literature of European integration has rarely addressed these issues head-on. Caporaso's recent article on the EU as a postmodern form of state was a notable exception (Caporaso, 1996). What follows from the argument here is that the structural aspects of integration deserve more attention. The subsequent section proposes various models which can be utilised towards that purpose. But such recommendations are meant as additions to the existing research agenda, not replacements of it. Ultimately, a comprehensive perspective hinges on the recognition of integration as multiple processes, and on the recognition that these are inter-connected in the manner indicated here.

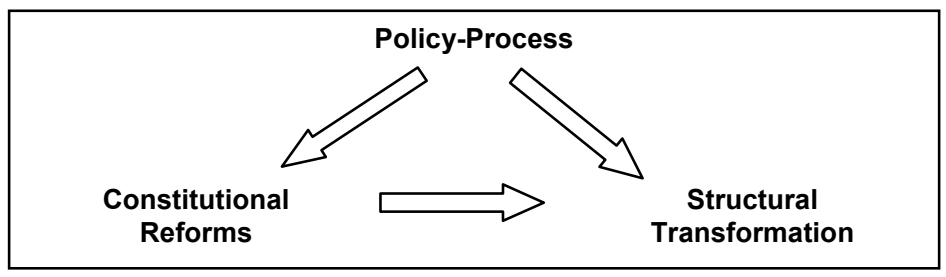

Figure 2 Dynamic Model of Change in European integration

This model indicates that research on any one level ought to recognise to the findings of analyses on the other two levels. Such a linkage between EU research on the micro- and macro-level will then not only have a value in itself, but will be of crucial significance in terms of the development of a comprehensive perspective to the EU. Observing the need for linking research concentrated on any one layer of change to 
the others, will thus also prevent false generalisations about how much or how little is actually changing.

\section{Studying the Longue Duree of European Integration}

From what has been said so far follows that political science has so far turned a rather blind eye to the elements of structure in the integration process and the way in which structural changes have potentially changed the arenas in which policy-making and treaty reform are being negotiated. In order to develop a greater sensitivity to these aspects, political science would do well to import ideas and approaches from other disciplines. Law, History, Sociology and International Relations have all generated structuralist perspectives which could enhance the more holistic approach to the study of European integration which is advocated here. This section briefly introduces some useful avenues and suggests ways of relating them to mainstream political science work on European integration.

It will be apparent from the preceding argument that structural analysis is closely tied up with a historical perspective. In an elementary sense, structuralist analysis implies the need to dig deep into history in order to identify the fundamental patterns of political life, to be able to gauge which are unaffected by short-term events and which are, in fact, changing (Tilly, 1984). The utility of long-term history thus lies in the disentanglement of current events from more long-term developments and in the isolation of trends towards path-dependency. As regards the development of what has been, until now, the primary ordering principle of political life - the modern state - this has been a common approach (Herz, 1957; 1968; Linz, 1993; Tilly, 1975; Anderson, 1974; Poggi, 1990). 
As far as the development of the European state system is concerned, path-breaking research of this long-term historical process has been carried out by Stein Rokkan and Otto Hintze. Their emphasis lay on the last major incidence of structural transformation: the establishment and consolidation of territorial states in Europe (Rokkan, 1973; Flora, 1981; Page, 1990). Recently, there have been attempts to return to this encompassing, cross-temporal comparison in European political development (Therborn, 1995; 1997).

In the study of European integration, one use of history has been the recourse to historical categories of governance that modernity and its state-centrism had done away with (Schmitter, 1992). Returning to the ordering principles of pre-modern political life has led to the suggestion that the current state of transformation can be likened to neo-medievalism - including the normative perils contained in such a move (Wæver, 1994; Evers, 1994).

Political structures are, first and foremost, the institutions of governance. In this context, 'institutions' is used as a broad term, denoting not only of hierarchical, governing organisations, but rather the formalised and continuously reproduced patterns of interaction in social or political life. In this understanding, political institutions are not simply the European Commission or other 'European institutions', but also 'the state' or 'European integration' (Jørgensen, 1996). Historical institutionalism thus goes further than the more traditional institutional analysis of the EU. To the extent that in western Europe the formal institutionalisation of transnational, previously 'international' politics is accepted as the norm, European integration has become an institution in this larger sense. In Sociology this has been identified as a fundamental change, denoting structural transformation in the west European state system (Bach, 1993). 
To be sure, the 'strength' or the 'power' of the state by which is meant the ability of member state representatives to affect certain outcomes - is a regular item in the literature. What is rarely questioned is the state as the primary ordering principle of political life in Western Europe. On the one hand, the state is an older, more entrenched and more easily recognisable institution and therefore deserves the analytical attention that goes with this significance (Evans et al., 1985; Cerny, 1990).

But this does not mean that European integration is not also an ordering principle of political life and must also be studied as a political institution - an institution that is partly complementary, partly competitive, to the state. While in a more immediate sense traditional state structures and emerging European structures are being fused in the process of integration (Wessels, 1992), a long-term vision of the process must recognise that the state is being superseded in its role of exclusively legitimating territorial governance (Christiansen 1997). In this sense, European integration - the growth of new forms of legitimate governance in Western Europe - is also a factor in the decline of the state as a source of political legitimation (Haaland Matláry, 1995).

The need for historical analysis and the view of European integration as a political institution links the present discussion to an approach that is sometimes called 'historical institutionalism'. The past decade has witnessed the formulation of a new research programme under the label 'new institutionalism' (see Evans et al., 1985; March and Olsen, 1984; Powell and DiMaggio, 1991; Thelen and Steinmo, 1991). As has been pointed out, this renewed attention to organisational factors in political life has taken very different forms (Koelble, 1995). More specifically, both reflectivist and rationalist strands of institutionalist thinking regarding politics and society have developed (Grendstad and 
Selle, 1995; Cammack, 1992; Gebhardt, 1992). It is the reflectivist variety of neo-institutionalism that has developed ways of integrating historical analysis and long-term developments in the study of political institutions.

Rather than going into the details of that approach, it should be pointed out that tools, methods and paradigms are being formulated in political science that intend to bring structural elements such as history and institutions into the analytical picture. One empirical application of this approach - the evolution of the principle of sovereignty (Krasner, 1988; Onuf, 1991; Philpott, 1995) - is also of high relevance for the study of European integration (Waever, 1995; Christiansen, 1994).

Historical institutionalism is, of course, making significant inroads into European studies (Bulmer, 1993; Peterson, 1995; Pierson, 1996; Olsen, 1995). To the extent to which such studies establish the link between long-term changes and micro-processes in the policy-making field, historical institutionalism provides precisely the kind perspective that is needed to close existing gaps. Bulmer's analysis of the governance of the single market is a perfect example (Bulmer, 1997)

Applying a historical-institutionalist perspective to the study of European integration would not suggest any particular view on the actual outcome of such an analysis. Opinions might well differ. Wessels has stated that

European integration is a 'thread woven into the fabric' of the European society at least in the 1990s. The Community and its institutions are more than just the 'political will' of heads of governments or just legal treaty properties (as important as they might be). They are reactions to persistent 
fundamental patterns of West European political and social developments. (Wessels, 1991, p.136).

In other words, a long-term vision of the integration process might identify persistent features of integration that go deeper than the (dis)agreements among current actors and their legal obligations. But another interpretation of history and of institutions might come up with a quite different view: institutions are not more than insignificant additions to an otherwise state-centred world (Milward, 1992; Mearsheimer, 1995; Mann, 1993). This notwithstanding, the value of the historical-institutionalist approach is to question the current configuration of actors, interests and powers and to make that itself, rather than its outcome, the subject of inquiry.

One way of overcoming the agency-structure dilemma, it has been suggested, is by changing also epistemological track. This implies a move away from a rationalistic epistemology towards a more constructivist understanding of politics (Onuf, 1990). In the present context a constructivist approach must stand for the way of studying how Europe has come to be seen as a political space for joint decision-making.

In traditional accounts of European integration it is all too readily accepted that politics and policies are defined within a European space. A more structural account of that process would focus on the creation, not of joint policies or common institutions, but on the discourses and practices which must have preceded these activities in order to make them possible. The argument here is that the European project is about more than economic rationality and utilitymaximisation. It is also, crucially, about those reflexive foundations that provide the legitimacy, the purpose and 
ultimately the rationale for common governance (Jørgensen, 1997).

Constructivism in the social sciences has made considerable advances in recent years, especially in the discipline of international relations (Schaber and Ulbert, 1994). This work can certainly contribute to new thinking in the study of the European processes. It is important, in this context, to examine the construction of 'Europe' - not in terms of the growth of an institutional framework, but in terms of the social construction of a polity. This includes, but goes beyond, the debate about whether there is a 'European identity' able to compete with established national identities (Smith, 1993; Garcia, 1993; Münch, 1993).

At stake is also the more general discourse about the 'Europe' - the way in which the region has come to be seen as a natural space for politics (even if these are adversarial). Such constructivist analyses on region-building have been proposed for diverse territorial levels (Neumann, 1992; Paasi, 1986). As regards Europe, there has been, until recently, only little attention to the formation of a coherent constructivist research programme (Jørgensen, 1995).

However, the building-blocks for a constructivist perspective on 'Europe' are there: in literature and the arts, in general, the presence of a specifically 'European' dimension is long recognised (Lützler, 1982). Yet, this 'Europe' is a construction: there is no 'natural' boundary to this Europe (Sperling and Karger, 1989, pp.13-16; Isensee, 1993). The acceptance of a specifically European perspective to politics in this region was, indeed is, contingent and competing with alternative visions such as 'the Atlantic' or 'the West'.

At the same time, the construction of this 'Europe' has depended on the parallel construction of an 'Other' against which a separate identity could be established 
(Neumann and Welsh, 1993). There are also diverse national and temporal interpretations of what 'Europe' actually constitutes (Wæver, 1990; Holm, 1993). Indeed, the success of the European project might well depend on the distinctive of the interpretation each nation can extract from the discourse on 'Europe'.

This approach indicates that the political meaning of 'Europe' has a structuring impact on the present which is, to a large extent, independent of any current rationalisation that is preoccupied with 'facts' or 'interests'. A constructivist perspective on the presence of 'Europe' is bound to show the elements of structure that are, respectively, underpinning and weakening the significance of that space. At the same time, a constructivist perspective will, of course, also confront the state with its 'unnatural' nature. Thus a straight record might be set where in the past the nation-state has often been reified as the only imaginable framework for political processes. Constructivism tends to illuminate the contingency of any form of structural configuration of politics, and, as such, would certainly assist a better understanding of how the integration of Europe has been coming about.

This section has sought to demonstrate that ontological choices matter, and that, in the past, the study of European integration has had a tendency to accord ontological primacy to political action. If this is criticism accepted, two items belong onto the integration research agenda: first, the development of structuralist perspectives on the integration process, in order to fill the gaps left by research based on an agent-primary ontology; second, attempts to resolve of the potential contradictions by agencyand structure-dominated views with the aim of developing a perspective on European integration that is both comprehensive and meta-theoretically consistent. 
The best-known approach towards the integration of actional and of structural explanations has come from Anthony Giddens, in the form of structuration theory. Essentially, it is the attempt of reconciling the explanatory power of both actors and structures by defining them as 'coconstituting' each other. The 'duality of structure' - the notion that structures constitute actors while, at the same time, these structures are being constituted by the continued and repeated action of the actors - is at the heart of this attempt towards ontological reconciliation (Giddens, 1977; 1983; 1984; Cohen, 1991)

Insights drawn from structuration theory and from the wider agency-structure debate could therefore be used here to link developments on the different layers of change identified here. In this way the attempt to link micro- and macro-level analysis regarding the causes and effects of integration would ensure the tenets of meta-theoretical consistency. It will also be a way of bringing the insights and values of legal scholarship - where structuration theory has already been utilised (Snyder, 1990) - more firmly into the fold of political science. Currently structuration theory, which has been widely debated in other disciplines, has only seen little application in the study of integration (Wind, 1996; Christiansen, 1997; Christiansen and Jørgensen, 1997). Together with constructivism and historical institutionalism more generally, it would be useful item in the toolbox of future integration theory.

\section{Conclusion}

The above discussion was consciously selective. This selectivity should not be misunderstood: structural elements from a variety of disciplines have been advanced so that they 
may be added to traditional work on integration theory in political science. Patterns of agency - the identification of actors, their preference formation, the distribution of power resources - were left out of the discussion. The reasons for this were twofold: on the one hand are patterns of agency, as we argued above, already dominant in the traditional, neofunctionalist and liberal intergovernmentalist theories of integration. On the other hand, it is precisely the shorttermism and agency-dominance of so much political science literature that renders it incompatible with the mainstream of legal work on the European Community.

This article has only signposted a comprehensive perspective on European integration - a perspective which recognises that integration involves a number of process of varying historical depth. Developing integration theory in a more inclusive manner would, in the first instance, seek more research into the long-term or structural effects of the integration process - what has been called here the longue durée of integration. Constructivism, historical institutionalism and structuration theory have been identified as fertile ground for the generation of such insights.

As a second step, there would need to be greater sensitivity to the identification of linkages between various levels. How do structural changes impact on the environment, resource base and interest structure of policymakers and IGC negotiators? How have repeated treaty reforms and policy-change affected the underlying structure of European governance? These are questions that past integration research has rarely addressed. To provide a framework for asking these questions, and to suggest directions in which to find the answers, was the purpose of this article. 



\section{Chapter 2}

\section{The European Commission}

\section{The European executive between continuity and change}

National governments like to claim that their European policies place them at the heart of the European Union, but it may be more appropriate to place the European Commission at this prime location (Nugent 2000). From the outset, when Jean Monnet became the first president of the Commission's precursor, the High Authority of the European Coal and Steel Community (ECSC), the institution has been closely linked to, even identified with, the progress of the integration project.

The Commission is central to the integration process because in most areas of EU policy-making it carries the sole responsibility for proposing new legislation. The monopoly of initiative with respect to most first-pillar matters has made the Commission a pivotal actor in the EU policy-process, placing it in a privileged position in relation to national governments, organised interests and the European Parliament. It has allowed the Commission a part 
in framing the issues, setting the agenda and, in a wider sense, shaping the evolution of the European Union.

Beyond initiating EU legislation, the Commission's functions also include the mediation - even 'manipulation' - of member state positions during the decision-taking phase of the policy-process (Schmidt 2000), and control over compliance with EU legislation once this has been passed (Mendrinou 1996; Peters 2000). Furthermore, in a range of areas, the Commission itself is either the decisiontaker (for example in competition policy) (McGowan 2000; Brent 1995) or policy-manager (for example in managing pre-accession assistance to the countries of Central and Eastern Europe) (Levy 2000; Laffan 1997). Finally, the Commission also has a role in informing citizens about EU policies (Mak 2000) and representing the EU's trade interests in international fora (Woolcock 2000).

The variety of tasks it has to perform within the system of European governance make the Commission a complex institution. It has to possess technical expertise in almost every area of government activity as well as an astute awareness of the politics of these issues, if it wants to see its policy proposals and other initiatives succeed. The need to handle the often contradictory demands of administrative expertise and political preference within the same institution can exacerbate tensions within the Commission. And pressure to meet an expanding range of tasks with often limited resources can create problems with administrative 'overload', which in turn may damage the efficiency and legitimacy of Commission actions.

The identification of administrative and political logics within the Commission make it essential to stress one fundamental point at the beginning of this chapter: the term 'Commission' is being used to denote a number of different 'animals': 'Commission' stands both for the college of 25 
individual Commissioners constituting the political, quasiministerial level of the institution, as well as for the body of more than 20,000 officials who make up its administrative services. In view of the tensions mentioned above, the relationship between these political and administrative levels of the Commission has been difficult.

In the early phase, Commissioners tended to be senior civil servants, but in the recent past have been recruited from among senior politicians in the member states (Donnelly and Ritchie 1994; MacMullen 2000). Commission staff are normally recruited through competitive examinations from across the European Union, but at the higher echelons of the administration appointments have traditionally involved an element of 'parachuting' - the appointment of senior officials according to national and party political patronage rather than by promotion through the ranks (Spence 1994) as well as the growing practice of filling Commission posts through secondment of officials from national administrations (Trondal 2001).

While the need to reconcile administrative and political responsibility within the Commission can be dated back to the origins of the High Authority, the more recent phase of dynamic integration following the creation of the Single Market has brought new pressures. Given the direct or indirect relevance of Commission activities for governments, interest groups, businesses and consumers, the institution is now frequently in the spotlight of public attention. This higher profile has had two consequences which are essential to an understanding of recent developments concerning the Commission: on the one hand, there is now an often critical, if not hostile, scrutiny of Commission activity by the - predominantly national media. In this respect, the focus is not only on potentially 
controversial policy proposals or decisions the Commission is preparing, say in areas of tax harmonisation or state aid control. Crucially, the focus is on the Commission itself, often with heavy emphasis on its arcane internal practices and its alleged propensity to mismanagement or even fraud (Grey 2000).

The second, related consequence is a lingering debate about the Commission's lack of public accountability. The Commissioners are nominated and appointed by national governments, and while they are not 'faceless bureaucrats', as critics sometimes claim, they can legitimately be called 'unelected'. Changes introduced in recent treaty reforms have enhanced the role of the European Parliament in the confirmation of the Commission President and the College of Commissioners have not altered this basic fact, and the legitimacy of the Commission has been precarious as a result. Indeed, when objections from MEPs to individual candidates for Commissioner posts caused a delay in the appointment of the Barroso Commission the public reaction was one of crisis, rather than seeing this as the legitimate consequence of the democratic process.

The combination of high political profile, administrative overload, media scrutiny and questionable public accountability has made for a heady brew in the 1990s. Jacques Delors, Commission President in 1984-94, had invigorated the institution after decades of 'eurosclerosis' by putting it into the driving seat of the successful and dynamic Single Market programme. But the next big project, the agreements on Economic and Monetary Union and on Political Union contained in the Maastricht Treaty, already saw the Commission's star wane. Delors' successor, Jacques Santer, assumed office with the motto 'Doing less, but doing it better', but towards 
the end of his term he became the victim of the volatile mix of political ambition, administrative mismanagement and fragile legitimacy which the Commission had developed in the 1990s. In response to criticism from within and outside the Commission, the European Parliament first instituted a Committee of Independent Experts to investigate fraud and mismanagement. When the EP then threatened to dismiss the Commission on the basis of the Committee's report (Committee 1999), emphasising the absence of either collective or individual responsibility in the Commission, the entire Santer Commission was forced to resign in March 1999.

The events at the end of the 1990s constituted a major crisis for the Commission, but it also constituted an opportunity to approach the first substantial reform of the Commission in twenty-five years (Spence 2000). The Prodi Commission had to embark on a wide-ranging process of reform which implied significant changes for the institution, the individuals working within it, and its relations with other institutions, the member states and the wider public. For a time, the 1999 crisis and the subsequent reform process appeared to have certainly weakened, even traumatised, the Commission. In the long run, though, the 'fresh start' afforded by these events may come to be seen as invigorating, and that ultimately a 'new Commission' will emerge as a stronger player in the policy process. At the end of the Prodi Commission, academic opinion on the outcome of the reforms remained divided (Rhinard and Vaccari 2005).

This chapter analyses the evolution of the European Commission against the background of these problems and opportunities. The next section charts the development of the Commission's role in the European policy process. Subsequent sections deal with the resulting pressures for the 
administrative and political levels of the Commission, before attention returns to the current internal and treatybased reforms. By way of conclusion, the chapter discusses the key issues for the Commission in view of the challenges ahead.

\section{Conflicting demands and internal tensions}

The above comments have already indicated that the Commission is having to deal with internal tensions such as the political/administrative divide (Christiansen 1997). Another such contradiction is the Commission's dual role of providing both stability and dynamism for the European Union. To some extent, this balancing act between dynamism and continuity which the Commission has to perform matches a related conflict: from the beginnings of the High Authority, Jean Monnet, its first president, had been aware of what he regarded as the dangers of bureaucratisation (Mazey 1992). He had wanted the High Authority to remain an elitist body of policy-making experts, rather than risk becoming bogged down in the quagmire of parliamentary politics (Wallace and Smith 1995) or in the minutiae of sectoral integration (Mazey 1992). Walter Hallstein, the first EEC Commission President and former diplomat, chose a more explicitly political approach to conducting Commission business. When clashing with de Gaulle, he learned to his cost what the dangers of a 'political' Commission were. The '1965 crisis' - which had France withdrawing from the Council for almost a year after a dispute over the Common Agricultural Policy - was as much about the content of policy as it was about the power of the Commission. De Gaulle's concern at this juncture was not only to preserve 
French interests in a particular policy field. In a wider sense, the crisis was sparked by - and put an end to Hallstein's ambition to turn the Commission into something like an internationally recognised 'European government'.

What followed the show-down between de Gaulle and Hallstein were two decades of a decidedly 'nonpolitical' Commission: implementing treaty provisions where it was acceptable to member states, but remaining passive where there was opposition from national capitals. The initiative on institutional reform was definitely left to member states and the European Court.

But while the experience of the 1960s spelled an end to far-reaching federalist ambitions, it did not incapacitate the Commission in its more subtle policymaking role. In what remained a cumbersome institutional framework and an unfavourable overall climate, the Commission executed its assigned tasks and indeed sought to extend Community competences. The main aim of the Rome Treaty, the abolition of all custom tariffs within the Community and the creation of a Common External Tariff by 1969 , was achieved ahead of schedule. But more than just the administration of agreed policies, and the successful management of two rounds of enlargement in the 1970s and early 1980s, this period also saw the Commission 'quietly' extending the limits of Community activity.

In fields such as education, research and development and the environment, on which the treaties were silent, the Commission developed, first, a Community agenda, and, subsequently, the policy tools to facilitate Community action. In regional policy the Commission sought to go beyond the straightforward budget bargain among member states and began to design policies such as the Integrated Mediterranean Programmes that actually had a substantial regional dimension. Progress in all of these 
cases was gradual, cumbersome and slow-moving, and yet these early advances were the essential foundations for the Commission's more ambitious and self-confident projects of the late 1980s.

The pattern of Commission activity in this period was to circumvent potential obstruction of national governments by involving a wide range of nongovernmental groups and interests in deliberation about new policy initiatives. Such groups and organisations were regularly drawn into the ambit of the Commission by its comparative openness to outside views and representation (Mazey and Richardson 1994). They would then emerge favourable to the development of a European policy in the design of which they had participated. The advantage of such a strategy was that the emerging transnational network of interest groups and non-governmental organisations, supportive of a Community role in social regulation, would eventually put pressure on national administrations and governments to 'fall into line'. At the very least, the Commission could point to 'demand' from private interests in a given Community policy, and in this way legitimise its activity in the unchartered waters outside the treaty.

Simultaneously, the Commission built up a body of 'soft law': it oversaw the growth of frameworks of rules, recommendations, decisions and practices in novel policy sectors which were strong enough to structure social and economic interests - leading them to accept that 'Europe matters' - without having to seek explicit member state approval by sending formal proposals to the Council. This construction of soft law continued to be significant even when policy-making in the wide variety of sectors become codified later (Snyder 1993). It provided valuable experience in a novel system of administration and implementation - a system in which the Commission cannot 
rely on hierarchy or coercion, but where its power must be based on negotiation and persuasion.

In this way, although its political ambitions had run dry, the Commission's capacity to mould social and economic interests, to construct agendas for EC action and to develop the innovative practices necessary for European governance, meant that the 1970 s and early 1980 s were an important phase in its 'maturation process'. It was on the basis of this experience that, with Jacques Delors taking up the presidency in 1985, there was a return to a proactive, political leadership from the Berlaymont. A number of factors - and many of them external to the Commission and even the Community itself - came together in the success of the '1992' programme. But there was also Delors' ability to invigorate and lead an administration that had in many areas shown the kind of bureaucratic fatigue Monnet had feared from the outset. At the end of Delors' ten-year tenure at the helm of the Commission its potential for political leadership (Drake 1995) had been demonstrated conclusively.

Jacques Santer may have tried to scale back the profile and politicisation of the Commission, concentrating instead on consolidation of policies and a series of modest reforms (Peterson 1999). But it was too late to return the genie to the bottle. Given the range of activities in which the Commission is now involved and the potential for any matter, however technical, to become a matter of controversy and thereby of 'high politics', the Commission could not shy away from publicity and exposure to public debate. The appointment of Romany Prodi - a former prime minister from one of the larger member states - to succeed the disgraced Santer in 1999 appeared as an acknowledgement of this state of affairs among national governments. Prodi did not shy away from either limelight or political controversy, although he soon had to confront a 
hostile media reception (Financial Times, 18 January 2000). The challenge of communicating from the centre to a broad and diverse (and increasingly sceptical) European public has increased further with the enlargement to 25 member states, and has accordingly been elevated to one of the key tasks of the Barroso Commission.

As a result of its increasing significance and high profile, the Commission has been facing a broad range of criticisms. It is castigated for being too bureaucratic or technocratic (for which read: insensitive to the political priorities of the day) as well as for too much political activism (for which read: too involved in deciding political priorities). Such criticisms of the Commission are contradictory, but not necessarily wrong. The fact of the matter is that there is an inherent contradiction in the Commission providing both political leadership and an impartial civil service to the EU system. The tension, if not contradiction, between the organisational modes underlying 'bureaucracy' and 'politics' were recognised early on as fundamental issues for the Commission (Coombes 1970; Scheinmann 1966). Insofar as there is a general problem of reconciling democracy and bureaucracy in liberal democratic systems (Pollit 1988), the problem for the Commission was simply the reproduction, perhaps exacerbation, of similar conflicts erupting in national administrative systems.

As already indicated at the outset, the Commission had been treading such a path between the scylla of bureaucratisation and charybdis of politicisation for a long time, and the resulting tension has been a persistent feature in the work and the public perception of the Commission. A recent review of the literature on the Commission reveals that this is still a dominant preoccupation of observers in the early $21^{\text {st }}$ century (Rhinard and Vaccari 2005). 
But from the mid-1990s onwards the Commission started to face more than the traditional balancing act between political bargaining and technocratic rule. The pressures on the Commission appeared as a triangular forcefield, in which the 'corners' were constituted by public accountability, attention to member state interests and a measure of independent expertise. This state of affairs reflects, for the Commission, the overall

contradictions between intergovernmental bargaining, functional administration and democracy [which are] embedded in the treaties establishing the European Communities (Wallace and Smith 1995: 140).

Such an observation leads us to concentrate on the study of the Commission's internal tensions. Studying the internal dynamics of the Commission is analytically useful because such a perspective avoids the pitfalls of envisaging the Commission as a single, unitary organisation, without having to abandon the idea of institutional self-interest. The institutional self-interest (or 'survival') argument, often advanced when it comes to explaining Commission activity (Moravcsik 1993; Fuchs 1995), while useful, is in itself not very profound. It does not tell us much about the precise content of that self-interest. As has been pointed out, in the making of public policy, a complex interaction is going on between individual bureaucrats' self-interest and their institutional environment (Egeberg 1995). Charting the Commission's activity in terms of the demands put on it by democratic, intergovernmental and technocratic pressures helps to fill the notion of institutional self-interest with content. Crucially, it allows us to account better for its change over time. 
Second, studying its internal dynamics will lead us to an understanding of differences within the Commission. It is a complex and varied institution, where organisational logics are not always compatible with each other. The coexistence of a number of distinct administrative traditions and policy styles (Richardson 1982; Burnham and Maor 1995), the autonomy of individual administrative units (Schink 1992), the way in which sectoral policies engender differing organisational cultures (Cini 2000), the persistence of national allegiance within 'inter-national' organisations (Egeberg 1999; Macdonald 2000) - all these are important in generating a comprehensive understanding of the European Commission.

\section{Expansion and functional specialisation of the Commission's services}

The European Commission is the product of a functionalist path of integration. While often seen as the champion of a federalist cause for Europe, its organisational design has largely been determined by the tasks it has had to fulfil within the European Union. As these have grown over time, so the Commission has grown in size and administrative specialisation. Commission services are organised in some 25 Directorates-General (DGs) and a number of centralized services which the Commission provides for the EU institutions (e.g. the Publication Office or the European Personnel Selection Office). These are predominantly sectoral in nature, that is, they provide for the specialised technical and administrative know-how in the various policy sectors in which the Union is active. In addition, there are 'horizontal' DGs which are dealing with crosscutting concerns such as the budget, personnel or financial 
control. (Nugent 1995, 2001). The European External Action Service, the establishment of which is foreseen by the Constitutional Treaty, may in the future constitute a new institutional form bringing together officials from the Commission, the Council Secretariat and the member states.

As a result of this process of expansion and specialisation, it is probably fair to say that the Commission is now both too large and too small. It is too large considering Monnet's initial plans were for a moderate supranational agency with limited functional responsibility. It is too large also for those who want to see European integration as an intergovernmental affair that can do without expansive bureaucratisation at the centre. Yet, at the same time, the Commission's services are small in relation to both the size of national administrations and the size of the problems it has to address. It is also for these reasons of size, and because of constrained financial and administrative resources, that the Commission now operates largely regulatory policies.

Most of the Commission's competences relate to the regulation of the internal market. Creating and maintaining the 'four freedoms' - the free movement of capital, goods, services and persons - has precedence over the regulation of individual sectors. The Commission continues to spend considerable resources managing the coal and steel, agriculture and fisheries sectors, but the balance has been steadily tilting. With the implementation of the '1992' programme, overseeing deregulation on the national level and building up a corresponding Europeanwide regulatory framework has taken centre-stage inside the Commission. There are essentially three aspects to this issue: facilitating the abolition of national rules, policing the emerging single market, and developing minimum standards for those areas affected by deregulation. 
The main task for the Commission here is in dealing with non-tariff barriers - the vast amount of national health, safety and trading standards inhibiting free trade and the free movement of production factors. In theory, there is a distinction to be made between the distortion of trade through illegitimate practices designed to benefit national producers, and the legitimate interests in social and environmental protection that member states may continue to undertake. In practice, member states had used taxes, technical and health standards for products and services, state subsidies and public procurement policies as subtle forms of protectionism, after tariffs and customs duties had been abolished.

A key tool in approaching this issue has been the mutual recognition principle, which the Commission first spelt out in its 1985 White Paper on the Single Market. Forcing all member states to allow trade in products once they have been licensed for trade in one member state, and the resulting process of regulatory competition, the introduction of this principle has allowed the Commission to concentrate on designing the minimum requirements that all products still have to fulfil, and on policing the market that is emerging (Majone 1993).

In this way, the Commission could leave the cumbersome process of harmonisation, which had bogged down Community activity in the decades before the Single Act, to market-led competition between member states' regulatory systems. It could then concentrate on the creation of the policy tools necessary to police the emerging market, and to devise auxiliary policies to provide for minimum standards in fields affected by deregulation. Yet even this was in many cases decentralised to bodies such as CEN and CENELEC - European-wide industry-based standardisation organisations seeking to develop non-binding standards for 
product safety and electrical appliances, respectively. Consensus on standards emerging from these private organisations would, once endorsed by the Commission, become de facto $\mathrm{EU}$ standards for the single market. Essentially, the Commission developed a policy of merely overseeing what became in many sectors market selfregulation.

Policing the internal market - which for the Commission has mainly meant the definition and application of rules for merger control and state aid control - has also become increasingly important. The Commission's DG Competition is widely seen as one of the most powerful sections of the administration. The direct, wide-ranging and open-ended powers given to the Commission in this field justify the observation that this is 'the first supranational policy of the Union' (McGowan and Wilks 1995). A legal scholar even likens the Commission, combining the roles of prosecutor and of judge in this policy field, to that of a 'leviathan' that must be 'bound' in the future (Brent 1995).

If the policing of the internal market has not been an uncontroversial process, then the same is true for the regulatory framework the Commission is building up to ameliorate its effects and provide for minimum social, environmental and health standards. Arguably, the Commission has often used the 'free movement' argument on a tenuous legal basis to build up additional competences. A result of this, and of subsequent treaty changes, are extensive policy competences in the education, environmental and social field, and policies which constitute more than simply a combat against non-tariff barriers (Pollack 1994; Eichener 1992; Mazey 1995).

The often uncertain legal basis, its limited financial resources and the sometimes hostile attitude of member 
states have forced the Commission to be innovative in going about the creation of such policy competences. The presence of a 'health and safety at work' clause in the Single Act, requiring only a qualified majority vote in the Council, has resulted in the Commission basing a whole host of social policies on this article rather than facing the national veto in the Social Chapter procedures (Cram 1993).

There is, however, more to the Commission's work than just the more or less extensive definition of the internal market programme. The Single Act had introduced, next to the 'four freedoms', Community competences in environmental policy and made the achievement of economic and social cohesion a goal of the integration process. The latter, in turn led to the reform and extension of structural funds for regional policy, the development of 'Trans-European Networks' and of a 'European Spatial Development Perspective' as well as the creation of the Cohesion Fund.

The reformed structural funds and the associated process of implementation and lobbying, in particular, brought state actors in direct contact with the Commission (Marks et al. 1996). The Commission actively assisted this 'partnership' by establishing an advisory committee composed of local and regional decision-makers (Hooghe 2000). The combined effect of these developments was, for the EU, the establishment of the Committee of the Regions in the TEU and for the Commission an involvement in European territorial politics.

Periodically expanding framework programmes for environment and research and development policy did much the same in these fields. Here, too, the Commission established direct links with affected actors in domestic systems: national administrations, business firms, universities, research institutes, interest and pressure 
groups. Again, the DGs involved increased in size and significance, but also had to resort to policy innovation and indeed experimentation in order to find a way of cooperating with often hesitant or reluctant national administrations.

After Maastricht, the Commission had accumulated competences in most fields that national administrations have traditionally controlled. In some areas, such as state aid control or the management of aid for Eastern Europe, the Commission's responsibilities are, in fact, unique even by national standards. In the hangover mood following the Maastricht ratification it came as little surprise, therefore, that questions should be asked about the 'limits' (Dehousse 1994) of this 'creeping' (Pollack 1994) extension of competences. In a variety of policy areas there were demands for 'decentralisation' - often little-disguised attempts at repatriation of Commission powers back to national administrations. At the same time, the Commission has had to accept the imposition of limitations set on its role even in areas like trade where its dominance had been longestablished (Meunier and Nicolaides 1999). In other areas in which the Commission had begun to acquire a recognised role - in particular CFSP/external relations (Nuttall 1996; Bruter 1999) and Treaty reform (Christiansen and Jørgensen 1998; Dinan 2000; Christiansen and Gray 2004) - it has to contend with the established role of the Council Secretariat. Further challenges to the 'community method' have come from the increased use of the Open Method of Co-ordination which tends to marginalise the role of the Commission.

Member states had already been attempting to regain some control over policy management and implementation through increased use of 'comitology' (Chapter 7, this volume). In addition, a growing number of 
'Decentralised Community Agencies' were established from the early 1990s onwards (e.g. the European Environmental Agency in Copenhagen, the European Monitoring Centre for Drugs and Drug Addiction in Lisbon, and the European Agency for the Evaluation of Medicinal Products in London) - a development that received a new impetus with the agreement to create new agencies in the areas of transport, health and food safety since 2000 .

Decentralised agencies are meant to facilitate the exchange of information and to prepare the harmonisation of national provisions in areas requiring detailed technical expertise. The creation of such agencies first appeared like an intrusion into what would otherwise have been the territory of the Commission, but now looks more like a sensible 'outsourcing' of specialised knowledge, allowing the Commission to concentrate on core tasks.

With respect to the impact of institutional changes elsewhere, it is worth mentioning the way in which the Council Secretariat has increased in significance as a result of recent Treaty changes. The 'triple-hatting' of the Council's Secretary-General as 'Mr CFSP' and WEU Secretary-General, the establishment of a CFSP policy unit in the Secretariat and its partial merger with the WEU secretariat have turned the Secretariat into an important institution in its own right. The next step of this evolution, as foreseen by the Constitutional Treaty may be the fusing of the posts of EU foreign minister and External Relations Commissioner, which, together with the creation of the External Action Service, will lead to a much closer cooperation between the two institutions. 


\section{The challenge of policy co-ordination}

But it would be misleading to look just at the conflict between the Commission and the member states without also recognising the incidence of conflicts and bureaucratic politics within the Commission. The dual aim of the Union, to provide for an internal market and for economic and social cohesion - reminiscent of the earlier distinction between negative and positive integration - has also led to conflicts between the DGs in the Commission championing different objectives. Internal disputes between the environment and the internal market DGs about the stringency of environmental protection, or between the Competition and Regional Policy DGs about the degree of public support for poorer regions (Wishlade 1993), are prime examples in this respect. The point to be made is a straightforward one: far from being a unitary actor, the Commission is an internally much-fragmented organisation. The term 'multi-organisation' has been coined to capture the way in which different logics are being followed by different parts of the administration (Cram 1994).

Consequently, there are dangers of fragmentation: inter-institutional contacts and relations proliferate in specific sectoral areas, so that ultimately each DG has regular contact with 'its' working groups in the Council, with 'its' committee in Parliament, and, indeed, with 'its' specific policy 'constituency of interests' in European society or market-place. The emergence of 'epistemic communities' - the development of and emergence of shared values among dedicated policy-makers, -recipients, advisors, and experts in a given field - is a recognisable phenomenon (Richardson 1996). The extent to which the Commission not only participates but actively encourages such transnational policy communities is only one side of the coin. The other side is the increasing difficulty of 
uniting the policy-making strands of various DGs behind a formal 'Commission line'. More significantly, perhaps, in addition to inter-institutional wrangles, deadlock within the Commission may be becoming an obstacle to Union decision-making.

Such intra-Commission conflict is not simply an issue for technocratic co-ordination. It affects the cohesion among Commissioners and, given the increasingly politicised nature of their work, leads to cabinet-style instances of 'bureaucratic politics' under the motto 'where you stand depends on where you sit' (Peters 1992; Page and Wouters 1994). It might well be a sign that it is because more power and significance now go with the job, that it has become difficult for the Commissioners to avoid turfbattles and political differences. But, whatever the underlying reasons, this has not made it any easier for the Commission to carry out its mission.

If the Commission has matured from a small agency to an extended bureaucracy, then individual DGs have turned from organisational sub-sections into quasiministries in their own right. Consequently, insofar as the Commission has been able, also on behalf of the EC/EU as a whole, to project the image of 'corporate actor' (Kenis and Schneider 1987; Fuchs 1995), and indeed to continue functioning as a unified institution, it is important to look at the institutional arrangements which bind it together. There are a variety of procedures to counter such centrifugal trends.

First of all, there are various bureaucratic mechanisms to provide for the harmonisation of Commission business. Most of these involve the Secretariat-General (SG), which is designed to co-ordinate the work of the various DGs. Its responsibility of coordinating the drafting of legislative texts within the 
Commission makes the SG the nerve-centre of the institution. The increasing difficulties of such horizontal coordination have led to suggestions for the development of the SG into something like a 'clearing-house' for the Commission's legislative proposals (Dehousse et al. 1992). Monitoring legislation, chairing the regular meetings of Directors-General, and representing the Commission in inter-institutional negotiations, the SG is the gatekeeper between the Commission's internal activities and its relations with other institutions.

Further mechanisms for co-ordinations are provided by the weekly meetings of Directors-General, chefs des cabinets and deputy chefs des cabinets, respectively. The cabinets, the personal advisory staffs of each Commissioner, are primarily responsible for relaying information back and forth between the Commissioner's desk and the Directorate-General under his or her responsibility. In this sense they play a crucial part in the vertical integration of political and administrative spheres within the Commission. But in the post-1992 phase their role in the conduct of the Commission's horizontal coordination has become equally, if not more, important. In monitoring policies conducted by other Commissioners and DGs, the cabinet members provide their Commissioner with the ability to keep track of the whole range of business at the weekly Commission meeting (Donnelly and Ritchie 1994; Ross 1994). This function is more than merely supportive of policy co-ordination: each Commissioner's capacity to follow and accept the whole of the Commission agenda is the necessary basis for the principle of collegiality - the acceptance that Commission decisions will be supported and defended collectively vis-à-vis other institutions and the general public. 
Thus there are elaborate efforts the Commission undertakes, through the formal 'inter-service consulation' procedure, but also at the Director-General and chef de cabinet level, to co-ordinate its policy-making activity internally. Yet the very need for such extensive coordination indicates the ways in which the Commission is different from ordinary bureaucracies. It lacks, in this context, a full-blown hierarchical structure: while the individual DGs provide the 'chain of command' which is traditionally associated with bureaucracies, the Commission - the college of Commissioners - is essentially a nonhierarchical body. Its members are equals, with equal voting rights, and their President a primus inter pares, even though, since Nice, the President's hand been strengthened in that he (or she) can request the resignation of individual Commissioners. However, that possibility is likely to remain an exceptional instrument meant for crises rather than the everyday work of the institutions.

What is crucially important in understanding the nature of the Commission is the principle of collegiality: individual Commissioners, unlike national ministers in some member states, are not meant to run their portfolio autonomously. Instead, decisions by the Commission are taken collectively: the entire college takes the decision (though that can be delegated to individual Commissioners or even Director-Generals for routine matters). Commission decisions require a simple majority of the college, though here as elsewhere in the Union the general practice is one of searching for common ground and maintaining a consensual approach. The collegiality principle also implies that a Commission decision, once taken by the college, must be supported by all Commissioners and that, in turn, all Commissioners take an interest in every portfolio. 
This co-ordination imperative places considerable strain on cabinets of the President and the Commissioners as well as on the Secretariat-General. Their work to coordinate policy is not only directed at identifying overlap, closing gaps and avoiding inconsistency, but also at bringing the principle underlying the Commission's work that the Commissioners speak with a collective voice closer to becoming reality. The officials involved have to look as much sideways as they have to look up and down. Procedural delays and inter-departmental differences within the Commission are a result of this basic requirement for co-ordination. But there is also the positive effect of a culture of compromise and bargaining, which prepares the Commission well for the inter-institutional negotiations that follow. The internal process of policy co-ordination will probably have brought out the sensitive issues of a policy proposal, and the result is something that is less likely to offend Council and Parliament than any directive that might be the product of a single DG acting autonomously.

\section{Problems of accountability and legitimacy}

The re-emergence of a proactive and 'political' Commission from the late 1980s onwards, together with the more general critique of the Union's 'democratic deficit', meant that there has been increasing focus on the democratic credentials of the Commissioners and of the Commission President (Haaland Matlary 1997). The most immediate response has been a redefinition of the Parliament's powers of supervision vis-à-vis the Commission. Until Maastricht, parliamentary powers over the Commission were purely negative: the EP could, with a two-thirds majority, force the entire Commission to resign - 
a provision potentially so damaging that the Santer Commission chose to resign voluntarily rather than face such a vote in the EP.

For a long time, the EP had no say in the more 'positive' process of appointing the Commission. A number of reforms have since changed this situation. First, the change in the Commission's term of office - extending it to five years and making it run parallel to the parliamentary term - enhanced the potential for linking the Union's party politics and the appointment for the Commission. This linkage was not very strong during the 1994 European elections, and the 1999 election was overshadowed by the wider crisis of the Commission. However, the potential for a more dynamic relationship in the future is certainly there, especially as parties become more involved in the legitimation of Union politics (Hix 1995). In 2004, the debate preceding the selection of the Commission President illustrated that this had become an appointment that was not, any more, solely about the preferences of Member States, but also that the choice of the Commission President needed to reflect the parliamentary majority.

One important development in this respect has been the investiture procedure, which requires the Commissioners-designate not just to undergo lengthy hearings in front of the respective committees of the European Parliament, but also to complete extensive questionnaires about their competence and their European credentials. The new investiture procedure may, in itself, not do much about the EU's 'democratic deficit' as long as the Parliament lacks a stronger link to the electorate (Hix 2000), but it is a reform that strengthens further the hand of the Parliament vis-à-vis the Commission. The revised procedure is part of an emerging model of appointments in 
the EU which provides the Parliament with considerable leverage vis-à-vis the EU's 'executive' (Jacobs 1999).

This turns the discussion to the more general area of the Commission's inter- institutional relations. Above we discussed the explosion of the Commission's contacts with interest groups and other non-governmental organisations during the past ten years. During the same time, the nature of inter-institutional relations between Commission, Council and Parliament has changed fundamentally. As we have seen, the Commission's relationship with the Parliament has become more adversarial as the EP's influence and self-confidence have increased - the traditional partners in the integration project are now also rivals (Westlake 1994).

The Commission's relations with the Council of Ministers have also become more structured, despite the balance between autonomy from national interference and dependence on member state support. One aspect of this has been the allocation of executive tasks to the Council Secretariat, as mentioned above. Another feature is the growth of what is now generally referred to as 'comitology'. Council and Commission share the executive function in the Union, and the preferred method of conducting the execution of policies is through the creation of specialised committees (Docksey and Williams 1994). With the expansion of Union competences, the 'comitology' structure has been greatly expanded: there are hundreds of these committees now, and their supervision not to mention legitimation - has become increasingly difficult (Buitendijk and van Schendelen 1995). In a wider sense, the expansive layer of committees dealing with consultation, co-ordination, management and implementation can be seen as a form of joint governance 
of EU policies by Commission officials and member states representatives (Christiansen and Kirchner 2000).

Perhaps more importantly, the Commission's relations with the other institutions have been altered through successive changes to the legislative procedure, leading to the co-decision procedure becoming the standard procedure for adopting legislation in the first pillar. Codecision requires constant communication and frequent mediation between the two legislative institutions. The Commission's role in this context is crucial not only with respect to its efforts of shepherding legislative proposals through the various stages of the procedure, but also to actively participate in the so-called 'trialogue', the tripartite negotiations between EP, Council and Commission if and when proposals come before the Conciliation Committee. It is a demanding role for the Commission which requires not only some flexibility in responding to member state positions that emerge in the course of the legislative procedure, but also good relations with MEPs and EP officials (Burns 2004).

\section{The challenge of continuous institutional reform}

The driving forces for the recent phase of reforming the Commission are derived from a mixture of external and internal pressures on the Union. Externally, the prospect of enlargement demanded institutional changes for almost a decade. Minor changes to the Commission resulted from successive treaty reforms, but - perhaps more significantly - internal reforms outside the treaty change became necessary because of the circumstances of the Santer Commission's resignation in 1999. The following Prodi Commission took office on a platform of reform, resulting 
in a White Paper on Commission Reform (European Commission 2000).

In fact internal reforms had already been initiated during Santer's Presidency (Peterson 1999), and to a limited extent the current reform programme is a continuation of earlier reforms. In the light of the events in 1999, there is now much greater impetus and political will to change the workings of the Commission. But at the more technical level, there are definite signs of continuity: for example, the DECODE exercise - a kind of internal census and survey of Commission staff and their occupation - was launched in October 1997, and its results informed Kinnock's reform programme (European Commission 1999b).

Further and far-reaching changes have become necessary in response to the report into mismanagement and corruption by the Committee of Independent Experts (Committee 1999) mentioned at the outset. These concern a number of issues both at the micro-level - in terms of internal auditing and accounting - as well as at the macrolevel - in terms of the redefinition of the relationship between Commission and Parliament. The former issues have been tied into the catalogue of reforms contained in the White Paper. The latter have in part been addressed by ad hoc arrangements between the new Commission President, the Commissioners and the European Parliament, and are in part on the agenda of treaty reform. Beyond, or rather below, the treaty reform process, the Commission sought to contribute to the debate about the future of European governance with the publication of the White Paper on European Governance. By proposing a more structured relationship between civil society and EU institutions, and in the process to re-position, and to legitimise, the European Commission as the central actor at 
the interface between societal demands and the EU legislative process (Tsakatika 2004).

The 1999 crisis could be seen to point in two quite different directions for the Commission: it could either be used to support the argument that the Commission is too unprofessional, badly organised and mismanaged to be entrusted with the high politics tasks with which it now deals on a daily basis - a rolling back of its competences and a greater degree of oversight by the member states would have been the logical response based on this reasoning. But the opposing view seems to have won out: that the Commission needs to be fundamentally reformed in order to be equipped for the tasks assigned to it by the member states.

In looking at the direction of these ongoing changes, three trends can be identified: the search for greater public accountability, a strengthening of internal hierarchy and an enhanced institutional independence for the Commission. These are, to some extent, interrelated developments, but reforms feed into each of these individually, making distinct trends discernible. There are further reform issues not captured by these trends, but they are of lesser significance in this context. The remainder of the section will discuss the direction of the Kinnock reforms in more detail.

In line with greater accountability to the public, the Commission is heading for a more hierarchical internal organisation. In part, the latter is a result of the former: if individual action is more clearly identifiable (thanks to greater transparency) and more likely to be subject to sanction (thanks to greater accountability), then the dynamics of command and control are more likely to respond. But there are also reform trends directly aiming at 
making the Commission more hierarchical and strengthening the role of the Commission President.

Beyond its aim of addressing the Commission's inherent need for co-ordination, the above-mentioned principle of collegiality has an important consequence: providing sustained leadership and giving direction to Commission affairs are extremely difficult to achieve. Traditionally, the lack of formal powers to 'govern' the Commission have been very challenging for successive holders of this office. The Commission President has to oversee an increasingly large administration and a diverse group of Commissioners. To advance, in this context, the course of European integration against at times sceptical national governments and an uncertain public takes special qualities. In retrospect it is perhaps fair to say that some of the previous Presidents failed in their task of actively promoting European integration. Much of what the Commission does and can do depends on the willingness of national governments to proceed with European integration. But the Commission President can exercise political leadership and thereby exert significant influence on the course of integration. Jacques Delors' two and a half terms in office are the best manifestation of this potential (Drake 1995).

What is important, in this respect, is that an effective Commission President's qualities must include not only a determination to advance the course of European integration, and an awareness of what is politically feasible, but also a relatively tight control over the institution itself. As is well documented (Ross 1994; Grant 1994), Delors' success as Commission President hinged also on his ability to 'run' the Commission itself. Towards this aim, the presence of a group of dedicated staff, in particular Delors' chef de cabinet Lamy, and Secretary-General Williamson, 
was critical in allowing Delors to streamline policy-making, to promote forcefully his strategy for a 'relaunch' of the Community and, ultimately, to enhance greatly the institutional standing of the Commission. A leadership role for the Commission depends therefore much on the individual choices made by the President in office - it is a capacity for leadership that depends on the utilisation of the Commission's resources (Nugent 1995).

Successive treaty revisions agreed at Amsterdam and Nice provided for two further changes here: first, that the designated Commission President now has to agree to the nominations of the other members of the Commissioners (Art. 158) and, second, that the Commission shall work under the 'political guidance' of the President (Art. 163). The President now also has a greater say in the allocations of portfolios to individual Commissioners.

Both Prodi and Barroso made use of his new power of 'political guidance' by appointing a number of new 'Commissioners' Groups', bringing a number of Commissioners together in order to oversee developments in a particular area (Reform, Inter-institutional Relations, External Relations, etc.). As these Groups are tasked with overseeing the co-ordination of Commission policy in a particular area, and since the Commission President reserves the right to attend and chair these Groups, they can be seen as a means not only of improved horizontal linkage of policy, but also of greater control of the college by the President.

During the Prodi Presidency there had also been a reform the cabinets, with mixed results: what was first a demand to appoint a chef de cabinet of a different nationality was then downgraded to chef or deputy chef and eventually became a minimum requirement of three 
nationalities to be represented among the members in the cabinet. Allowing for the nationality of the Commissioner, this has meant the appointment of at least two non-nationals - which is one more than was required previously. The size of cabinets was also reduced to six members.

When Prodi took over as Commission President, he also initiated a territorial shift: Commissioners had to leave of the Breydel Building where up to then the entire college has been residing, and moved to new offices close to their respective services. While this assisted the vertical integration of the work done by DGs, cabinet and Commissioner, it made horizontal co-ordination among cabinets and the college more difficult and may thus have contributed to a more fragmented Commission. Barroso, upon taking office, reversed this decision and brought the college back together into the same building - conveniently just as the Commission was able to move back into the Berlaymont, its historical headquarters, which has been closed for refurbishment for some 13 years.

Changes were also made at the top of the administrative level of the Commission. While a new rule that Directors-Generals may not be of the same nationality as their Commissioner has led to some movement among the top grades (Peterson 2000), Kinnock has also stated on more than one occasion that the practice of 'flags on posts' (Spence 1994) will come to an end (European Commission 1999a). Given what was said earlier about the nature of appointments in the Commission, this development can be regarded as the beginning of a 'cultural revolution' (European Voice 1999). The effort to maintain broad geographical representation will remain, but it will be a matter for the Commission to decide who gets which job.

The reform White Paper, while talking the language of new public management, may yet make the Commission 
a more traditionally bureaucratic organisation, with greater central control over the activities of its various parts. At the same time, treaty changes and secular developments promise to make the college of Commissioners more like a traditional cabinet, with the ability of the President to direct, and dismiss, individual members. The sum product would be a more hierarchical institution.

The Nice Treaty included changes with regard to both in the size of the Commission and the appointment of its President and its members. The question of the size of the Commission has been resolved in the following manner: from 2005 the Commission will include only one national from each member state. Implying the loss of a second Commissioner for the larger member states, this concession contributed to their demand to increase their relative voting power in the Council and the Parliament. As such, this reform of the Commission was part of the wider confrontation between smaller and larger member states at Nice.

Finally, the Nice Treaty also contained changes in the appointment procedure of the Commission President and Commissioners. The European Council is to select the Commission President, and the Council is to adopt the list of Commissioners, by qualified majority vote - a departure from the previous provision where these decisions required unanimity. President and Commissioners will be formally appointed by the Council by QMV, after they have received the approval by the European Parliament. This is a reform that may be seen to reduce the hold of individual member states over members of the Commission; the clear link between Commissioner and member state has, however, been reinforced through the new provisions mentioned above. 
Dependence on support from the European Parliament has become more significant, whereas the Commission President now has greater freedom to act independently of guidance from national governments. It is important, however, to remember that, in the main, formal changes have been outlined here, and that informal influence from the member states is, if at all, only indirectly affected. But the formal changes are already quite significant, in that member states are increasingly bound to lose control over the appointment procedures, both at the Commissioner level and at the level of senior officials. The Treaty changes giving the Commission President new powers while making him (or her) more directly accountable to the EP ought to marginalise the role of member states - once the President has been nominated. As regards senior officials, it will have to be seen whether, after the turmoil of the initial changes, a new modus vivendi develops, or whether member states and/or informal networks based on nationality find a way to play the new system in a fashion similar to the old one.

\section{Conclusion}

The past decade has been an extremely turbulent period for the European Commission. At the outset was the ambitious and largely successful project by Jacques Delors to reposition the Commission within the system of EU governance. But the advances the Commission had made had been bought with credit, on the assumption that the Commission would in due course deliver efficient and accountable decision-making. At the end of the decade, the bills kept coming in, and the modest reforms offered by Jacques Santer were not enough to cover the debt. The year 
1999 was a nadir for the European Commission, but it has also opened the door for a unique opportunity to overhaul the institution and restructure its place within the Union's architecture.

The wide-ranging reforms implemented under Prodi and Kinnock sought to modernise and 'streamline' the institution had to confront bureaucratic inertia, staff unions and the vested interests of national governments. The latter are bound to lose their privileged access to Commissioners and officials, if the Commission as a whole is to operate in a more transparent, accountable and 'consumer-oriented' fashion. But while direct access for member states may be waning, co-operation and co-ordination between Commission and Council Secretariat is becoming more important. More important still will be the Commission's relationship with the Parliament, not only in the extraordinary circumstances of investiture or potential dismissal, but also with respect to routine decision-making.

Beyond the formal process of internal reform, which had been largely completed by the time Barroso took office, there is the anticipation of further changes and challenges ahead. Apart from the implementation of the changes which would have been required by the Constitutional Treaty, if that was ratified, the new Commission also needs to manage the institutional impact of enlargement (Christiansen and Gray 2005). This concerns inter alia the impact of officials recruited from the new Member States will have on the nature of the Commission's administration. There is, for example, the likely impact on language, with much greater use of English language rather than the traditional French among the new recruits. The whole culture of language use will be affected, both in terms of fewer languages used in internal meetings and documents (these already feature almost only French 
and English) and in terms of pressure on Commission staff to keep documents requiring translation as short as possible. Thus the counterintuitive effect of the arrival of new nationalities among the Commission staff, and the increase in the number of official languages may actually be a rationalisation of language use inside the Commission.

Similarly, one should also expect the arrival of new administrative cultures to challenge the traditional modus operandi in the Commission. This will most likely be a gradual change, but over time there is the expectation that the Commission will be transformed by thousands of new staff from Central and Eastern Europe. However, what the medium- to long-term impact of the arrival of different administrative traditions will be is difficult to predict. On the one hand, it may exacerbate the already fragmented nature of the Commission. This a significant number of new staff with a very different culture of public administration may be making their mark on the institution, just as the arrival of a wave of officials from Sweden did lead to a push for greater transparency in the work of the Commission. On the other hand, the new nationalities in the Commission may 'dilute' the existing patterns of different national cultures, proving better chances of the development of a genuine European administrative culture. And, last but not least, the arrival of new Commissioners will have an impact on the nature of politics in the college, suggesting a Commission that is becoming more liberal than interventionist. This trend has already been visible in initial moves by the Commission that indicated that regulatory activity might be curbed in comparison to the previous Commission. It was also reflected by Barroso when outlining his plans to the European Parliament, where he stated his intention to do less, but to do it better incidentally a statement that sounded uncannily like Jacques 
Santer when he presented his programme some ten years earlier.

The Commission continues to face numerous challenges both internally and vis-à-vis the outside world. Recent reforms which have sought to make the institution leaner have yet to demonstrate their medium and long-term effects, and the same is true with respect to the impact on enlargement. The need to communicate policies and institutional choices at the European level effectively to the wider public is greater than given the problems the Constitutional Treaty has been facing in the course of ratification, and thus communication has become a key task for the Barroso Commission. And while its role as a strategic leader in the public debate and the making of policies may have been waning in the post-Delors era, the Commission remains central to the European project. The high political profile of the Commission sits uneasily next to the growing need to maintain independence and to work closer together with the European Parliament, the Council Secretariat and the Member States. The long-standing tension between the politicisation and bureaucratisation is as alive as ever, and after a decade of sometimes significant reforms one may be forgiven for thinking of the famous dictum from Tommasi di Lampedusa's novel that "everything has to change so that everything can remain the same". It is a different Commission that has to face the new challenges of the $21^{\text {st }}$ century, but it is also a Commission that is still subject to the tensions that have been inherent in this institution from the outset, and its remarkable development will continue to be driven by the dynamics resulting from the way these tensions play out in the future. 


\section{Chapter 3}

\section{The Council of Ministers}

\section{Facilitating interaction and developing actorness in the EU}

Given its prominence in the decision-making process of the European Union, the Council of Ministers is strangely elusive: it is both a permanent institution and the frequent gathering of ministers from all member states, representatives or officials. It is part of the EU's executive (with the European Commission) and part of the EU's legislature (with the European Parliament), but its work is less transparent than either of the other two institutions. The Council occupies the impressive Justus Lipsius buildings in the heart of the Brussels Euro-district, yet several times a year ministerial meetings take place in Luxemburg. All this may make it difficult to generalise about the Council, but it also makes for an interesting institution.

At the most basic level, the Council provides for the formal representation of member states in the European Union. Ministers, attending Council meetings, arrive with positions derived from domestic preferences regarding the issues under consideration. Yet this almost immediately 
leads to one fundamental tension in the work of the Council: given that member state positions on policyproposals are rarely ever identical, the Council is not simply an - or even the - decision-making organ of the Union, but also the main forum for negotiation in the EU.

The idea that a single institution should be the channel of the multiplicity of national interests is a subset of the wider 'unity in diversity' paradox of the European Union. The Council is generally regarded as an intergovernmental institution, making it the focus of those who regard the member states as being in ultimate control of the integration process. Yet - in part precisely because member states have sought to maintain a close hand in the running of the integration process - the Council itself has become increasingly institutionalised. In the first years of the new millennium, the Council's Secretary-General was also acting as the EU's High Representative for Foreign Policy, and the Council Secretariat was becoming the hub of the EU's foreign policy, military and internal security bodies. Thus there has been increasing emphasis on what is common rather than on what is intergovernmental in the work of the Council - reinforcing a trend that had already been identified at the beginning of the 1990s (Wessels 1991). The Council may not (yet) be a supranational institution in its own right, but it certainly has moved on from being purely a site of decision-taking and the forum for bargaining among representatives of national governments for which it was originally conceived.

This chapter will examine the institutional evolution of the Council. In doing so it will look at the variety of institutional forms that together constitute the Council. The following sections discuss the politics of the Council as a meeting place of national and sectoral interests respectively. Given the expansion of the EU's agenda and 
the number of sectoral Councils, a special focus here will be the concerns about coherence and co-ordination in the Council's work. The next section looks at the role of the Presidency - an important institutional device which was, in part, a response to the problem of co-ordination - before turning to the European Council, which has become an increasingly important part of any Presidency's work programme. After this excursion into the Council's 'superstructure' follows a discussion of its 'underbelly' of committees and working groups, where much of the routine matter of Council decision-making takes place. A further section charts the role of the Council Secretariat, with particular emphasis on its gradual rise to institutional prominence. The conclusion assesses the increasing institutionalisation of intergovernmentalism and the issues that this raises for the future evolution of the Council, and of the EU in general.

\section{The Council of Ministers: institutionalising intergovernmentalism}

The Council is the main, formal point for the representation of national interests in the EU policy process. There are, of course, numerous ways in which member states influence EU business informally, whether this is through the lobbying of the Commission in the pre-proposal stage of the legislative process, the impact of domestic party hierarchies on voting in the European Parliament (EP) or the use of comitology committees to oversee the implementation of policies. But in a formal, constitutional sense, the Council provides for the systematic involvement of member state representatives in almost any aspect of European integration. 
Before going further in discussing the nature of the politics of the Council, it may be useful to distinguish between three different levels on which this interest representation occurs:

- Ministerial level: ministers from all member states meeting in the composition of different sectoral Councils.

- Heads of State and Government level: prime ministers and/or presidents meeting as the European Council (while this is not a formal decision-making body in the Council structure, it is so closely associated with the work of the Council that it ought to be included here).

- Administrative level: national officials and/or experts meeting in committees and working groups.

While subsequent sections will look at the latter two of these categories, this section will concentrate on the role played by ministers in the Council. Nevertheless, it is important to recognise from the outset that the work of the Council is embedded within this wider institutional structure.

Ministers from all member states attend Council meetings in order to take decisions on the legislative proposals from the European Commission or amendments proposed by the EP. As implied above, they do so in a wide range of different sectoral Councils. What was initially the preserve of foreign ministers soon involved also ministers of agriculture and, with the widening of the EU's competences, an ever-wider range of ministers, which in the case of the more federal EU member states, can also include ministers from the regional level. By the mid-1990s the number of sectoral Councils had mushroomed to more than 
20 , roughly matching the number and designation of Commission Directorate-Generals or EP Committees. However, as co-ordination of such a growing number of Council formations was getting too difficult, a reform of the Council, agreed at Seville in 2002, reduced this to nine configurations in which the Council can meet.

Member states have two rather different, even opposing, rationales for representing their interests in the Council: on the one hand, individual governments will seek to see their policy preferences realised in decisions about EU policies, if necessary (and possible) against the opposition of other governments. In this respect one can distinguish between various 'cleavages' separating national governments (Hix 1999), including the Left/Right split, differences about the speed and reach of European integration and, with respect to the EU budget, the divide between net-contributors and net-recipients. In addition, there has been frequent reference to the division between small and large Member States, but this has been a dividing line more in the context of intergovernmental conferences than in legislative decision-making in the Council.

On the other hand, the Council also serves the collectivity of governments to advance a common interest in the intergovernmental aspects of European integration. This refers less to the substance of policy, and more to the structure of the Union and to questions like interinstitutional relations and the use of decision-making procedures. Even in this area, though, there is scope for disagreement among national positions, since some member states, in particular some of the smaller ones, may prefer more supranational solutions (like a strengthened role of the European Commission) to the more intergovernmentalist positions of others. Much of the defence of member states' structural interests takes place in the European Council and 
in Intergovernmental Conferences, but it also plays a part in routine policy-making. This has contributed to some of the particularities of the EU system of governance like the decentralised implementation of policies, the creation of independent agencies or the growth of comitology.

When looking at the politics of the Council, much depends on the decision-making procedure at force in any given area. The main distinction here is between 'unanimity' and 'qualified majority vote' (QMV). Unanimity requires a decision to be taken without opposition from any member states. In other words, a single member state can block a decision, which is why unanimity is the decisional mechanism applied to policy areas or issues which are sensitive and where some member state would not accept to be overruled.

The application of QMV, on the other hand, provides opportunities for coalition-building, confrontations between different camps and decision-taking against the votes of one or more member states, as long as the required majority agrees. The majority is 'qualified', because it is more than the simple or absolute majority of member states. Instead, in areas in which QMV applies, each member state has a weighted vote recognising its relative size. In 2005, the qualified majority therefore required not only the majority of Member States, i.e. at least 13 out of 25 states, to be in favour.

In addition, the weighted votes of these states have to constitute at least 232 votes out of a total of 321. States' voting weights range from 29 for the four larger member states to 3 for Malta. 


\begin{tabular}{|l|c|}
\hline Germany, France, Italy, United Kingdom & 29 \\
\hline Spain, Poland & 27 \\
\hline Netherlands & 13 \\
\hline $\begin{array}{l}\text { Belgium, Czech Republic, Greece, Hungary, } \\
\text { Portugal }\end{array}$ & 12 \\
\hline Austria, Sweden & 10 \\
\hline Denmark, Ireland, Lithuania, Slovakia, Finland & 7 \\
\hline Cyprus, Estonia, Latvia, Luxembourg, Slovenia & 4 \\
\hline Malta & 3 \\
\hline TOTAL & $\mathbf{3 2 1}$ \\
\hline
\end{tabular}

Table 1: Votes per Member State in the Council of Ministers (February 2005). When Romania and Bulgaria join the EU in 2007 they will have 14 and 10 votes respectively, raising the total number of votes to 345 .

This also goes to show that Council votes are hardly proportional to the population size of the member states: proportionality would give Germany 200 times - rather than 10 times - as much weight as Malta, to point just to the most obvious discrepancy.

In an effort to counter-balance this lack of proportionality, the Nice Treaty introduced a further condition for achieving QMV - the population criteria. A Member State may ask for a confirmation that the Member States in favour of a decision represent at least 62 per cent of the total population of the EU. This additional 'population element' to Council voting privileges larger 
member states over smaller ones further, but it benefits Germany, with more than a quarter of the current EU population, in particular.

QMV is of fundamental significance for the EU for a number of reasons. It constitutes the departure from the principle of 'one state, one vote' which characterises the nature of decision-making in traditional intergovernmental institutions. More important still is the acceptance of member states that legally binding decisions can be taken against their will, which is what giving up the national veto implies. That is why QMV can be seen as one of the defining features of the European Union. But it is also for this reason that the application of QMV has been highly controversial. While it had been written into the Rome Treaties, it was challenged by President de Gaulle when what he saw as core interests of France were being threatened by the integration process. Temporarily suspended by the 'Luxemburg Compromise' in 1966, the non-application of QMV has been blamed for its part in the decades of 'eurosclerosis' that followed. But QMV survived, not only in terms of a gradual return to the actual treaty provisions, but also through the expansion of its application in every instance of treaty reform since the Single European Act.

With the increased use of QMV, the weighting of votes has become more important, both in terms of member states' individual votes and in terms of the threshold for the achievement of a qualified majority. The matter is particularly thorny in the context of enlargements, as the arrival of new member states inevitably opens the issues of the relative weights not only of the new members, but also of the existing ones. This had already been a bone of contention in the preparation for previous enlargements and was only resolved through the so-called Ioannina 
compromise, in March 1994 - just before the EFTA enlargement (Hayes-Renshaw and Wallace 1997).

The issue of Council voting weights has required a more fundamental reform in view of the eastward expansion of the EU, the pressure for re-weighting had become strong, especially from the larger member states (Best 2000). It had been a on the agenda of the IGCs preparing the Amsterdam, Nice and Constitutional Treaties, and on every occasion it proved to be a highly contentious issues. Both the Nice Treaty and the negotiation of the Constitutional Treaty almost failed on this obstacle. The re-weighting of the votes for the Member States was one of the issues that led to the failure of the Brussels European Council in December 2003 , and a solution was only possible under the subsequent Irish Presidency in the first half of 2004. The Constitutional Treaty provided for a simplified 'double majority' system which requires the support of at least 55 per cent of Member States (at least 15) representing at least 65 per cent of the total EU population, though it remains doubtful whether this provision will come into force in this way, given the problems that have arisen in the course of ratification. Under the same Treaty, the use of QMV and co-decision procedure would have become the default mechanism for EU decision-making, calling it the 'ordinary legislative procedure', though unanimity would still remain for significant exceptions from this rule.

The high-profile battles among state leaders about issue of voting weights in the Council in the last instances of treaty reform betray somewhat the limited use that Member States actually make of majority voting. In fact, there is a strong tendency among states to act consensually, rather than seeking to achieve results through partisan voting. According to recent research, more than 80 per cent of Council decisions are taken consensually, and in some 
years the figure is as high as 97 per cent (Heisenberg 2005). Thus, the vast majority of decisions - many more than would be formally required - are taken by consensus.

In an apparent paradox, the introduction and expansion of QMV has supported this tendency. Under QMV the dynamic of decision-making is a desire by all states to be either among the winning majority or among the blocking minority. However, if it is impossible to construct a blocking minority, states, even when they have misgivings about the proposed legislation, will rather seek to join the majority, in return for amendments, rather than be 'left out in the cold' of a losing minority. And in the same vein, the states holding a qualified majority will usually continue to negotiate to reach a consensus rather than outvote a number of countries, in the knowledge that in future instances of legislative decision-making they may be at the receiving end.

Consensualism in the Council is also a reaction to the particular nature of EU policy-making more generally. In a system of decentralised implementation, with the EU institutions relying to a large extent on national parliaments to transpose EU laws, on national authorities to implement these and national courts to adjudicate on the basis of them, the wisdom of taking decisions against certain Member States when their subsequent co-operation is required, may be doubtful. Instead, more efficient implementation may be gained by negotiating their agreement to the legislative act, and thus to be more certain of compliance later. In other words, efficiency losses in decision-making are expected to be outweighed by efficiency gains in implementation.

Consensualism in Council decision-making can thus be explained in terms of the rational interests of the Member States, even, and perhaps especially, under conditions of QMV. But over time it has also become part 
of the culture of negotiation in the Council (Heisenberg 2005). The development towards consensual decisionmaking is in part also a reaction to the way in which the structure of the Council forces Member States to represent their interests along sectoral lines, thus creating the bureaucratic politics discussed in the following section.

\section{Beyond interstate relations: bureaucratic politics in the Council}

The debates about re-weighting of votes and the extension of QMV reflect the expectation that the politics of the Council pitch member states against member states. Given the nature of the Council as the main forum for the representation of member state interests, that is justified. But the politics of the Council go beyond the confrontation between different member state positions. Indeed, the development of the Council - the expansion in the number of sectoral Councils - is a powerful illustration of the way in which the concept of 'national interest' needs to be unpacked when studying the politics of the European Union. Looking at the relationship between the various Councils reveals the differences in opinion not just between, but also within countries.

As mentioned above, the initial Council was composed of foreign ministers, whose meeting is termed the General Affairs and External Relations Council (GAERC). As the extension of Community competences has progressed, other Councils dealing with more specialised matters have been created. After the Seville reforms of 2002 there are nine Council configurations. 


\begin{tabular}{|l|}
\hline General Affairs and External Relations \\
\hline Economic and Financial Affairs \\
\hline $\begin{array}{l}\text { Cooperation in the fields of Justice and Home Affairs } \\
\text { (JHA) }\end{array}$ \\
\hline $\begin{array}{l}\text { Employment, Social Policy, Health and Consumer } \\
\text { Affairs }\end{array}$ \\
\hline Competitiveness \\
\hline Transport, Telecommunications and Energy \\
\hline Agriculture and Fisheries \\
\hline Environment \\
\hline Education, Youth and Culture
\end{tabular}

Table 2: The different configurations of the Council of Ministers (February 2005)

The more prominent among these are the Agriculture Council, the ECOFIN Council and the Competitiveness Council (comprising the previous Internal Market, Industry and Research Councils). While the Seville reforms have nominally reduced the number of configurations, they leave open the opportunity for Member States to meet in different compositions, bringing together ministers with different portfolios on different days - a development that in itself may generate new challenges of internal co-ordination.

Each of these Councils brings together the ministers who have domestic competence in the respective area. The frequency of their meetings differs according to the volume of EU decision-making in that sector. For example, foreign 
ministers or agriculture ministers hold monthly meetings, whereas employment ministers meet only four times a year.

The sectoral Councils provide a forum for the representation of diverse national interests in their respective areas, but they also have a wider significance as an arena for the socialisation of ministers who share a common interest in the management of the sector for which they are responsible domestically. This is a major departure from domestic politics, where meetings at ministerial level - usually in the cabinet - will pitch the ministers from different departments against one another. In a domestic cabinet meeting, the positions of, say, the transport, environment and budget ministers are bound to reflect the different sectoral and bureaucratic interests at play. The emergence of such interdepartmental differences would be expected from a bureaucratic politics perspective (Peters 1992).

In the Council, sectoral ministers, who 'at home' have to fight lonely battles in cabinet meetings, will find themselves in the company of colleagues from the other member states with often similar experiences from their domestic background. In addition, they all will share the knowledge of the subject-matter, are used to the lobbying from organised interests in the field and are familiar with the political and administrative problems in the area. It is on the basis of such a common background, that they meet in the context of the Council. If the right conditions are present, an esprit de corps may grow among them participation in, for example, the Agriculture Council, will emphasise identification as the UK Agriculture Secretary as well as the UK Agriculture Secretary. In that sense, the Council fulfils a function not only in terms of the representation of national interests, but also in terms of the creation of transnational policy communities at the highest 
political level. This 'reverse dynamic' is even stronger at lower administrative levels, where bureaucratic interaction is more frequent, and where much of the routine decisionmaking takes place - a subject to which we will return below.

The development of a transnational sense of community in the Council will depend on numerous factors, including the length of time individual ministers spend in their jobs, the frequency and intensity of their meetings, the contentiousness of issues under discussion and the antagonism of domestically determined positions to be represented (Egeberg 1999). Socialisation is actively encouraged through the increasingly frequent recourse to 'informal' Councils - Council meetings which are organised by, and held in, the country holding the Presidency, rather than in the usual meeting rooms in Brussels or Luxembourg. It is a practice that originated among foreign ministers, who started in the mid-1970s to hold 'Gymnich-type meetings' in the context of European Political Co-operation. Foreign ministers extended this practice, first to the General Affairs Council, and subsequently to other configurations. . The rationale for holding such meetings, which are limited to five per Presidency, is the expectation that a meeting conducted in an informal atmosphere and without the pressure to take routine decisions permits a more relaxed discussion of the broader strategic issues and the general direction of policy. Initially conceived as meetings without a set agenda, they now provide an opportunity to address a specific issue in greater depth (Council of the European Union 1999). Often informal Councils conclude by espousing a certain vision for the development of EU policy in a given area.

The point to be made here is that the Council has to be regarded as more than simply the meeting place of 
national interests. It is also the meeting place of different sectoral and bureaucratic interests and thus exposes the complexity - and potential contradictions - subsumed by the concept of a 'national interest' (Lewis 2000). But if individual Councils do develop an esprit de corps, dividing lines between the various Councils are likely to emerge, in line with the observation about domestic bureaucratic politics made above. In institutional terms this means that there is also the potential for internal fragmentation and that co-ordination across the various sectoral Councils becomes an issue (Lipsius 1995). It is in this respect that the role of the GAERC Council has been elevated, so that it stands above the sectoral Councils. If issues cannot be resolved, they can be referred to the GAERC, though the crowded agenda there means that the potential for the resolution of the often highly technical issues of other Councils may be limited (Lipsius 1995). There are other mechanisms for coordinating the activity of the sprawling complex of Councils. These include the Presidency, the European Council, the work of preparatory committees, in particular the Committee of Permanent Representatives, and the Council Secretariat. The following sections will look in more detail at the role these institutions play in the structure of the Council.

\section{Member states as agenda-setters: the role of the Presidency}

The Council's position as the key legislative institution of the Union implies a reactive role: it has to respond to the proposals made by the Commission and, increasingly, to the amendments proposed by the Parliament. That is why traditionally the Commission rather than the Council is 
regarded as the agenda-setter in the EU policy process. But there are a number of ways in which national governments have sought to regain control of, or at least play a part in, the setting of the Union's agenda. The most important mechanisms to be discussed here are developments linked to the Council: the EU Presidency and the European Council.

The Presidency started off as a seemingly functional innovation in the Council: to share among national administrations the task of organising Council business and chairing the various ministerial meetings and working groups (Westlake 1995). Every six months, one member state takes over this role, and ministers and officials chair any of the meetings that are convened during that period. Apart from allowing individual meetings at any level to run more smoothly, this also facilitates the continuity of negotiation and decision-making over time. The institution of the Presidency also permits a greater degree of both horizontal co-ordination (across the various sectoral Councils) and vertical co-ordination (between meetings of ministers, permanent representatives and national officials). The growing number of sectoral Councils is one reason why the Presidency has become more important over time: as more EU business is being debated and decided in a larger number of fora, there is greater potential for inconsistency and therefore greater demand for effective co-ordination (Wallace 1985).

Yet the Presidency is anything but an innocent functional creation. The institution of the Presidency is political not only because it affects the relationship between the individual member state, the collectivity of states and the EU institutions, but also because it is closely linked to the management of the EU's external affairs - arguably a key area of 'high politics', and one from which member 
states have long sought to exclude the more supranational institutions. Starting in the 1970s with the establishment of European Political Co-ordination and now in the context of the Common Foreign and Security Policy, the Presidency is responsible for the external representation of the EU's foreign policy positions. This is a delicate task, given the increasing visibility of the EU in world politics, and considering that it requires the state in question to handle foreign policy in a manner that is different from the execution of its national foreign policy. Both the nature of the issues, and the way in which these are handled, will be different from that country's conventional national foreign policy.

The nature of European foreign policy means that there is bound to be a tension between, on the one hand, the need to respond quickly to issues or crises as they happen, and, on the other, to maintain a process of inclusive consultation with all member states. Similar demands are present in other policy areas, putting great pressure on the government holding the Presidency. Therefore the Presidency not only constitutes a substantial administrative responsibility, but also involves high political profile and carries with it the accompanying risks and opportunities.

For these reasons of political balance and administrative efficiency, changes to the Presidency system have been discussed since the Nice Treaty, both in the context of the internal Council reforms agreed at Seville in 2002, and in the Convention on the Future of Europe. There had been plans in the Convention to create Team Presidency, but in the end the 2003-4 IGC chose the more traditional method of individual member states holding the Presidency for six months on the basis equal rotation. However, a declaration attached to the Treaty foresees a decision by the European Council that would create 
'groups' of three member states that would jointly organise and co-ordinate their subsequent presidencies.

Thus the Constitutional Treaty, if ratified, would not formally change the current practice of the rotating Presidency. However, in addition to laying the foundations for the team presidency concept, it does provide for important changes, such as the European Council President (chairing the European Council) and the EU foreign affairs ministers (chairing the GAERC) which would have a major impact on the nature of the Presidency.

The change that was agreed in the Seville reforms and is currently in practice is that of the two forthcoming Presidencies co-ordinating their plans each December by adopting an annual operational programme. This has led the two countries who each year hold the Presidency for six month to work closely together, not only in terms of agenda-setting and legislative planning, but also in terms of organisational and logistical terms. In a way, this is a move towards informally achieving something that the idea of the Team Presidency was supposed to deliver: Member States working together and sharing the administrative burden while providing the Union with greater stability and continuity in its overall direction.

The establishment of a rotating Presidency among member states also reaffirms the role of national governments in the EU structure. In fact, in terms of the distinction of different types of interest representation made earlier, it emphasises the role of the individual country rather than the collectivity of member states. In that sense, the Presidency has become an important, albeit limited, counterweight to the loss of national autonomy in the EU generally, and in the Council in particular. Holding the Presidency permits the respective national government to prioritise certain issues during its term and to manage the 
agenda accordingly. For example, if the country holding the agenda is a southern or northern member state, it may want to push a specific geographical concern such as, respectively, the Euro-Mediterranean Partnership or the Northern Dimension. On the other hand, if the country holding the Presidency is a net contributor to the EU's budget, then it has a stronger interest in privileging budget reform in the setting of the agenda. However, as the above discussion of the need for co-operation among subsequent Presidencies by adopting annual programmes demonstrates, with internal reforms and after enlargement, the constraints for any individual Presidency have grown enormously. If the cost of the Presidency has always been the administrative work-load, and the gain the ability to shape EU decision-making, then in recent years the costs have increased and the gains diminished.

Shaping the EU's agenda is also difficult for any Presidency because this agenda is influenced by numerous factors outside the control of individual actors. Some of these are structurally or externally determined, especially since much of EU business is now conducted in the form of multi-annual programmes. This is true both for spending programmes like the structural funds and for regulatory programmes, for example in environmental or social policy. When such programmes need to be renegotiated, any Presidency will have to address these accordingly during its term. Developments that are 'external' to the EU, for example the need to respond to the changes in Central and Eastern Europe through an accession strategy, will also impose themselves on the agenda of any country holding the Presidency. Other member states or actors like the Commission or foreign countries will also raise issues that the Presidency may be unable to ignore. Crucially, the Presidency is expected to act as an honest broker with 
regard to issues raised by other member states and will have to take these into account when constructing the agenda.

It is only within these limitations that the Presidency can emphasise - rather than impose - its own priorities in the setting of the agenda. In fact, the Presidency is very much a double-edged sword, precisely because of these limitations and the requirement to appear as an objective keeper of the common good (Wallace 1993). A Presidency which is seen to be abusing its agenda-setting role and its chairmanship in the pursuit of its own national interest will be ineffectual, and it may even be that it is easier to defend a certain position or push a specific interest when not holding the Presidency. In any case, holding the Presidency requires the member state in question to strike a fine balance between, on the one hand, the pursuit of a national agenda - which may have built up over a considerable period of time - and, on the other hand, the necessities of effective decision-making and agendamanagement - which may override the national interest.

Beyond the rational calculation of interests, the Presidency also performs a powerful symbolic function: it confers upon the incumbent country a special role which permits the government to emphasise its specific understanding of the goals and the direction of the integration process. The Presidency unifies the European and the national identity of the state, enabling the government to pursue a discourse (and perhaps a European policy) which may at other times prove elusive. For domestic consumption, the image of a country holding the Presidency removes the potentially antagonistic perception which often regards the state as pitched against an external 'Europe'. In its place governments seek to put the image of a country that, while asserting its role and identity within the Union, works for the common good - an imagery that is 
accompanied by symbols, logos and slogans specifically designed for the occasion. In a wider sense, the Presidency also serves as a powerful symbol externally that European integration is driven by states, rather than being a process happening to them.

The term of the Presidency begins formally with the identification of a number of key themes at the outset of the term. These themes are part of a communication to the Council, European Parliament and the Commission - and the wider public - in the first week of the term, and form the basis of a more detailed work programme involving the various sectoral Councils over the coming six months. In addition to the prepared programme, the Presidency will be expected to lead the EU response to unexpected developments and crises, whether these are internal to the EU or part of its foreign policy. An effective Presidency therefore needs both a clear vision of what it seeks to achieve during its term and an ability to respond rapidly to the changing political circumstances of the day. Again, there is a balance to be struck between strong leadership and intensive consultation in order to ensure that all member states agree to, comply with and, if necessary, contribute to the policy that emerges from the deliberations in the Council.

In practical terms, the Presidency raises substantial resource issues for the country concerned. Setting the agenda and co-ordinating EU business across the range of sectoral Councils and administrative levels requires much preparation before, and constant attention during, the term. The greatest part of the pressure will be on the relevant sections in foreign ministries, prime ministers' offices and any other ministries that would usually perform a coordinating role in the domestic EU process. Staff in these departments will now be required also to relate regularly 
and systematically to their counterparts in other member states. Also the EU sections in sectoral ministries will be affected by their country holding the Presidency, as they will have to co-ordinate the discussions or negotiations with regard to dossiers falling into their area of competence.

The member state's Permanent Representation in Brussels will probably witness the greatest change to its volume of work - Perm Reps regularly double their staff numbers in the run-up and during the period of the Presidency, given the additional workload they have to cope with. One significant resource issue is the need to chair meetings of working groups, committees of Councils in Brussels: given that these meetings number in the hundreds over

the term of any Presidency and imply preparation as well as physical presence, there is much demand on staff time at both ministerial and official level as well as a greater reliance on the assistance of the Council Secretariat (see below).

The resources of any country are stretched by the demands of the Presidency, but this has been an issue particularly for the smaller member states. For them, the combination of greater political responsibility and extraordinary demands on resources are especially challenging. On the other hand, more used to compromising national positions in the context of EU negotiations, smaller countries are more likely to avoid the temptation of overlaying the formal responsibilities of the Presidency with their own political priorities - something which has been a more obvious problem for the larger member states. In either case, the size of a member state matters for the conduct of the Presidency, both in terms of the resources of the administration and in terms of the political weight of the incumbent. That is one reason why in the determination of 
the sequence of countries holding the Presidency there has been a departure from the simple alphabetical rule that was in place until the accession of Spain and Portugal. A new sequence has been specifically written into the Treaty, in order to ensure a balance between larger and smaller member states (Westlake 1995). In late 2004 the Council decided on a Presidency calendar stretching to 2020 and including not only all the new Member States, but also the future Member States of Bulgaria and Romania.

\begin{tabular}{|l|l|l|}
\hline Year & January-June & July-December \\
\hline 2005 & Luxembourg & United Kingdom \\
\hline 2006 & Austria & Finland \\
\hline 2007 & Germany & Portugal \\
\hline 2008 & Slovenia & France \\
\hline 2009 & Czech Republic & Sweden \\
\hline 2010 & Spain & Belgium \\
\hline 2011 & Hungary & Poland \\
\hline 2012 & Denmark & Cyprus \\
\hline 2013 & Ireland & Lithuania \\
\hline 2014 & Greece & Italy \\
\hline 2015 & Latvia & Luxembourg \\
\hline 2016 & Netherlands & Slovakia \\
\hline 2017 & Malta & United Kingdom \\
\hline 2018 & Estonia & Bulgaria \\
\hline 2019 & Austria & Romania \\
\hline 2020 & Finland & \\
\hline
\end{tabular}

Table 3: Calendar of Presidencies as agreed by the Council of Ministers on 13 December 2004 


\section{Leadership from the top? The evolution of the European Council}

It is also the responsibility of the Presidency to organise regular meetings of the Heads of State and Government. Above, reference has already been made to informal Council meetings, but the Presidency is also responsible for running ministerial meetings with representatives of third countries, for example from the accession countries, or landmark conferences on topical aspects of the integration process. But the 'highlight' of any Presidency is the organisation of a summit meeting that originally was not contained in the founding treaties but has become one of the pivotal institutions of the EU: the European Council. What began in the 1970s first as extraordinary summits of prime ministers eventually became normalised as regular meetings of heads of state and government, hosted by the Presidency. With the passage of the Single European Act in 1985 the new institution, by then recognised as the European Council, was formally incorporated into the Treaty. At least twice a year, the European Council brings together the heads of state and of government - i.e. all prime ministers and the presidents of France and Finland - as well as the President of the Commission. While the European Council does not have a formal role in the legislative process (that is a change that would have come with the ratification of the Constitutional Treaty), it plays an important part in the wider decision-making process of the Union.

Each Presidency usually holds two European Council meeting throughout its term. These meetings usually take place in March (which is earmarked as a regular review of the Lisbon Strategy), in June, in October and in December. Due to the inherent significance of a meeting at the highest political level, the European Council 
functions as a stocktaking exercise for the Presidency - an opportunity for decision-makers as well as observers to see how much progress has been achieved with respect to the Presidency's work programme. Beyond stocktaking, the European Council has become a focal point of the decisionmaking process. Particularly in cases where there has been deadlock in the sectoral Council, and where the foreign ministers in the GAERC Council have been equally unable to reach agreement. In this situation, the European Council can function as the arbiter of the last resort. In order to be more proactive about future planning and giving direction to the work of the Union, the European Council has decided to adopt a 'multiannual strategic programme'. The first of these was agreed in December 2003 by the six countries holding the Presidency in 2004-2006 (Council 2003).

In contrast to the ministerial Council meetings, which have become routine matters in the EU policy process, the European Council remains a high profile event that can concentrate the minds of the decision-makers. The Presidency, in particular, will want to see their European Council meeting regarded as a success - which means prime ministers need to be seen taking decisions on the major issues. It is because of this particular dynamic of the European Council that it has on occasion given fresh impetus to specific issues or to the integration process at large. Especially with respect to the 'big issues', such as budget reform or enlargement, the European Council, rather than the Council of Ministers, has been the forum in which landmark decisions have been taken (Bulmer and Wessels 1987). Decision-making in the European Council has always required a consensus among member states.

This is an interesting reversal of roles, since critics originally expected the European Council to be the more conservative player in the integration process (Sasse 1975; 
Wessels 1980). The initial expectation was that the meeting of heads of state and government would reassert national interests and reign in ministers who, in the course of frequent meetings in the Council, had been socialised into compromising too quickly domestically agreed positions in the search of EU-wide agreement. This may well be the case in certain instances, but the European Council has also seen vested sectoral interests being overridden at the highest political level. After all, it is at this level that package deals and trade-offs, these quintessential features of EU policymaking, are best constructed. And as it has become more difficult to strike such deals in the fragmented world of ministerial Councils, the European Council has increasingly performed this role.

In the 1990s, there has been a marked increase in the frequency of treaty reform, with three major revisions of the founding treaties contained in the Maastricht (1992), Amsterdam (1997) and Nice (2000) Treaties. Each of these treaties takes its name from the place at which the respective European Council met in order to take the final decisions and to sign the final act. This symbolises the significance of the Presidency for running - and concluding - the negotiation of Treaty reform. IGCs are mainly conducted at the level of senior officials representing the member states in weekly meetings, with participation also from the Commission and the European Parliament. There are regular meetings also of foreign ministers in order to provide political guidance, and any European Council meeting held during an IGC constitutes a forum to review the state of the negotiations. The European Council meeting which is to conclude the IGC and agree the draft treaty will largely be taken over by the need to reach agreement on the last remaining - often most controversial - aspects of that round of treaty reform. 
The Presidency and the European Council are key institutions in the European Union: they reaffirm the role of individual countries and of the highest political level in the integration progress. As such, they have proved to be an integral part of a Euro-polity that is being constructed with, and by - not against - the member states. In practical terms, they both constitute mechanisms for co-ordination across the various areas of EU activity and provide the political leadership that may otherwise be missing in a Union of 25 and more member states. And they offer opportunities for national governments, and for the collectivity of states, to influence the setting of the EU's agenda and to maintain control over the direction of EU policy. In that sense, they are aspects of the institutional structure which assists member states to balance the agenda-setting powers of the supranational institutions, in particular those of the European Commission.

The Constitutional Treaty took the actorness of the European Council one step further by introducing the post of President of the European Council. This role of this new President would be to work towards greater cohesion and dynamism in the European Council, and represent the EU internally and externally. One has to wonder to what extent this post will be more than a symbolic role, given that there may be little to do for the President in-between European Councils, and given also that the function of external representation should not prejudice the powers of another post to be newly created, that of the EU Foreign Minister (which is discussed below). But what may be a frustrating position for the individual performing it, still shows that the Member States seek institutional solutions to achieve greater unity and facilitate collective decision-making among themselves - intergovernmentalism in the $\mathrm{EU}$ is getting ever more institutionalised. 


\section{Administrative integration: the committees and working groups of the Council}

The Council's relationship with the Commission is often characterised as one of rivalry, with the Commission pushing for further integration, with the Council holding back and providing member states with a mechanism to hold the Commission in check. In reality, the situation is more complex, not only because the European Parliament is an increasingly potent player in a tripartite relationship, but also because both the Commission and the Council are internally more differentiated than these one-dimensional images suggest (Christiansen 2001). Chapter 5 in this volume demonstrates the degree to which intergovernmental dynamics impinge on the work of the Commission (Christiansen 2005). The reverse can be said of the Council, where we can witness an accelerating trend towards a greater degree of institutionalisation.

The previous sections have emphasised the fluidity of Council business, with different ministers meeting in different places, guided by a Presidency that changes hands every six months. But the Council is a central institution of the European Union, with a physical presence in Brussels, an expanding number of permanent staff and a certain capacity for independent action. The building blocks of this institutionalisation of intergovernmentalism are, on the one hand, the structure of committee and working groups which do the preparatory work for the ministerial meetings, and, on the other hand, the Council Secretariat, which provides organisational, logistical and legal backup for the meetings of ministers and officials. This section and the next will look at each of these aspects of institutionalised intergovernmentalism in turn.

The institution 'Council of Ministers' extends well beyond the regular meetings of ministers. In fact, much of 
the legislative decision-making of the Council is done in committees and working groups which 'prepare' the ministerial meetings. With the expansion of the number of ministerial Councils, the number of committees and working groups had also grown exponentially, as there are numerous specialised committees and working groups working for each individual Council. The number of such committees and working groups had risen to about 250 in the 1990s, but has since then been reduced in line with the reduction of Council configurations agreed in Seville.

It is at this administrative level that the bulk of the routine work of the Council is done. Council working groups are the first port of call for Commission proposals and, if applicable, EP amendments. Here, national officials who are familiar with the technical detail of the measure in question vet Commission proposals, EP amendments and the various opinions of representatives emerging in the meeting with a view to their respective domestic preferences.

At the heart of the Council's committee structure stands COREPER, the standing committee of permanent representatives. Its members are the member states' "ambassadors" (or their deputies) to the EU, heading their countries' permanent representations in Brussels. As such, they fulfil a dual role which perfectly characterises the function of the Council's committee structure as the 'hinge' between member state and European Union more generally (Christiansen and Kirchner 2000). Permanent representatives are an important part of the individual countries' system of interest representation as well as being an integral part of the EU's decision-making process. Wearing the 'national hat', permanent representatives are gatekeepers of information and interests, working across the range of issues and regularly committing their member state 
to decisions in the process. Wearing their 'EU hat', they help to co-ordinate the work of the sectoral Councils and of more specialised working groups by preparing the agendas of Council and of European Council meetings (de Zwann 1995). Indeed, permanent representatives help to keep the agendas of ministers free for sensitive questions or the debate of politically contested issues, as COREPER itself takes decisions on matters which are considered routine business or on which member states can more easily find agreement.

COREPER stands at the top of a hierarchy of the numerous committees which form part of the Council of Ministers (Hayes-Renshaw and Wallace 1997). In fact, a distinction needs to be made between the committee of permanent representatives, who meet as COREPER II, and the meeting of their deputies, which is known as COREPER I. In addition, there are a number of specialised committees - for example, the Standing Committee on Agriculture or the Political and Security Committee -which consist of senior officials from the ministries in the member states. Like the two COREPERs, these committees receive their workload from working groups made up of officials or experts from national or regional administrations, who have been evaluating and searching for agreement on the detailed policy proposals issued by the Commission. Within the allotted period, the working groups or specialised committees either reach agreement on the measure in question or else notify the permanent representatives of the need for further discussions. It is at this stage that administrative issues start to be overtaken by political considerations (Westlake 1995).

As items move up through the Council hierarchy, from working group to COREPER and eventually to ministerial meetings, they are being designated as either ' $A$ ' 
or 'B' points (or, in the case of COREPER, 'I' and 'II' points) on the agendas of the respective meetings. An 'A' point implies that the issue has been settled at a lower level, and it will usually be passed as a matter of course at the higher level, with no further discussion required. Ministers, when meeting in the Council, will therefore concentrate on the ' $\mathrm{B}$ ' points of the agenda, indicating the - much smaller - number of items on which officials or permanent representatives have not been able to reach agreement in their preparatory meetings. It is worth emphasising that the bulk of Council decisions is effectively agreed here: according to estimates, some 70-80 per cent of all decisions made in the Council are already prepared in COREPER or in the Council working groups, and then only formally taken by the Ministers through the 'A' points procedure.

A look at the committee structure of the Council demonstrates the degree of 'administrative interaction' between national and European levels (Wessels 1990). Every month, Council working groups and committees bring together thousands of officials from the ministries and regulatory authorities of the member states in Brussels. Here they interact not only with representatives from other member states, but also with officials from the Commission and the Council Secretariat who also participate in their meetings. In addition, they are likely to be the object of attention from lobbyists and organised interests who will seek to influence the decision-making process in one or the other direction. The volume and the intensity of these bureaucratic interactions has a number of significant consequences for European governance. First, it does establish a strong and permanent presence of member state administrations at the European level. This deserves emphasis, also because frequent references to the 'Brussels bureaucracy' in the media and in the political debate tend to imply that the corridors in Brussels are only populated by 
Commission officials. This is obviously misleading, as the number of national officials travelling to, or living in, Brussels in order to attend Council, committee and working group meetings is probably greater that the number of Alevel officials in the Commission.

Second, in terms of the decision-making process, it is important to recognise administrative interaction in the Council as a two-way process. Interests are channelled from the national to the European level, but in the process officials are also becoming aware of the positions taken by other countries and will communicate these back to their superiors 'at home'. On the one hand, there are opportunities here for genuine problem-solving and the search for best practice, making the Council's committee structure an important site for the transnational integration of member state administrations (Lewis 2000). On the other hand, the participants in working group meetings will recognise the limits of any emerging consensus and - if politically acceptable - will adjust their negotiating position accordingly. At times, this can mean that negotiators, rather than receiving orders from the national capital as to what position they should take, end up telling their masters what position in a shifting debate they can take. Researchers have also pointed to the resistance by officials in the working groups - those who have the technical expertise in a given area - to hand over issues for decision-making to generalists such as the diplomats in COREPER. There, package deals linking issues from otherwise separate arenas - the staple diet of COREPER - may compromise the detailed technical work that has already gone into the deliberation of a particular proposal. The dynamic of this interaction between specialists and generalists contributes to proposals often spending long periods of deliberation in working groups, and a high share of them (eventually) being resolved there. 
Often the nature of deliberations in Council working groups is characterised as 'technical' rather than 'political', and of course it is the case that here we have meetings of technical experts, usually attachés from the member states' permanent representations, rather than political office-holders. However, it would be simplistic to convey the impression that the issues under discussion may not be political - as the events such as the BSE crisis have demonstrated, even highly technical issues have the potential to turn into major political controversies. Instead one can look at the way in which issues are discussed, deliberated and negotiated in the working groups in terms of processes of politicisatisation and de-politicisation (Smith et al.2005). Depending on instructions, political sensitivities and dynamics in the negotiations, issues emerge from the Council working groups as 'political' (i.e. in need to be resolved at higher levels) or 'technical' (i.e. they can be resolved by technical experts).

The recognition of the nature of the Council as an arena for two-way exchange, rather than a site of onedirectional representation of national interests, is related to a further point about socialisation. This was already mentioned in the context of ministerial Councils. If anything, this dynamic effect of frequent interaction in transnational meetings is even more important at the administrative level. With party politics and media attention (normally) taken out of the equation, officials can concentrate on the technical necessities of the issue at hand. They will have to work within the confines of a politically circumscribed negotiating space, but within these limits there is much potential for collegiality and group dynamics. This includes not only the potential development of a common identity or the growth of an epistemic community, but also the opportunity for individual participants to influence the proceedings based on their knowledge, the 
strength of their argument or negotiating skills rather than purely on the political weight of their member state (Lewis 1998). That is why it is justified to look for the supranational rather than only the intergovernmental features in the system of Council working groups (Beyers and Dierckx 1998).

\section{Towards 'actorness': the elevation of the Council Secretariat and the Secretary-General}

Administrative interaction within the structure of the Council already demonstrates the difficulty in clearly distinguishing between supranational and intergovernmental dynamics of the European institutions. The picture becomes even more blurred if the Secretariat-General of the Council is entered into the equation. Here we have an institution whose original purpose was simply the logistical assistance of regular meetings of ministers and officials from the member states, but which has gone a long way towards developing into a political institution in its own right.

The core function of the Secretariat-General remains the support of the meetings of working groups, committees and ministers in the Council. This ranges from the provision of meeting space, via the taking of minutes and dissemination of agendas, supporting papers and minutes, to assistance through legal advice and research services. The Secretariat is the institutional memory of the Council, and as such is the ultimate guide to working methods, internal procedures and past practice. It is the legal and procedural know-how, in particular, which has helped the Secretariat to become a distinct player in the Council. In advising member states on the procedures by which decisions are taken, and on legal questions arising 
from the drafting of legislation, the Secretariat makes an important, albeit hidden, contribution to the decisionmaking process (Beach 2004; Christiansen 2002).

Beyond assistance to the Council generally, the Secretariat works in particular for, and with, the Presidency. In the preparation of meetings, but in particular in the drafting of joint opinions or legal documents afterwards, the Secretariat will assist the Presidency (Sherrington 2000). It is here that demands on the administrative resources of the member states, especially of smaller countries, are being counterbalanced by administrative support from the Secretariat. In such cases, when the member state holding the Presidency relies heavily on the services of the Secretariat, the two operate closely together, with the Secretariat rather than the national capital taking on an influential role in drafting minutes, agendas and legislation.

The Secretariat's role of assisting the Presidency with legal and procedural advice before, during and after meetings of national representatives is of political significance in the context of any important decision taken in the Council, but even more so in the course of an Intergovernmental Conference (Christiansen and Jørgensen 1998). Given the legal implications of any treaty change and the complexity of the existing constitutional arrangements, the expertise present in the Secretariat's legal service provides it with an important role in the process of negotiations (Hayes-Renshaw and Wallace 1997). Crucially, though, it depends on the attitude of the Presidency whether that potential is being realised or not: a strong Presidency with clear goals and an ability to manage the demands of the role effectively may not defer to the Secretariat's opinions. A weaker Presidency, on the other hand, may leave much of the work - and the opportunity to 
influence the direction of negotiations - in the hands of Secretariat officials.

If the Secretariat has a role in the EU's decisionmaking process, it may be worth asking what its interests are. A simple answer would point to the institutional interests of the Council, as the Secretariat is bound to benefit, or suffer, from any change in the Council's institutional standing. But the Secretariat's attitude to institutional reform may differ from one issue to another, and would also depend on (the nationality of) the officials involved. In general, though, it makes most sense to look at the Secretariat in relation to the European Commission. In the past, both institutions have been keen to take over wider responsibilities as the competences of the EU were being enlarged.

Against this background, the Secretariat has been remarkably successful to gain an executive role in the more intergovernmental policy areas of the Union, and in particular with respect to the development of the EU's common foreign, security and defence policies (Presidency of the European Union 1999). In doing so, the Secretariat has acquired new competences in representing the EU abroad. The European Commission, whose responsibilities in areas such as trade, development and humanitarian aid make it an important player in the management of the Union's external relations, is 'fully associated' with the CFSP. Through its President, the Commission also represents the EU at G8 summit meetings of major industrial powers. But the central institutions of $\mathrm{EU}$ diplomacy are now firmly located in the Secretariat, turning it into a new actor in the conduct of the EU's external relations.

The process began with the EPC Secretariat, which had been established outside the existing institutional 
framework of the Community, being integrated into the Council Secretariat through the Maastricht Treaty. After the addition of a 'Policy Planning Unit', the Secretariat also contains 'task forces' on the different geographical areas of CFSP activity as well as a Situation Centre for crisis management. Also attached to the Secretariat are the EU's observer mission in the former Yugoslavia and the growing number of Special Envoys appointed to co-ordinate EU policy to troubled regions like South-Eastern Europe, the Middle East and the African Central Lakes region.

Compared to the foreign policy machinery of states, this is still a very small administration, but through cooperation with the member states' diplomatic services and the Commission's network of representations in third countries there would be growing potential for effective joint action (Financial Times 2000). For much of its history, there has been a search for 'actorness' in the intergovernmental nature of CFSP, and the use of the Secretariat as the home of an emerging EU foreign policy bureaucracy is one answer to this aspiration. A further, farreaching step has been the creation of the post of High Representative of the CFSP through the Amsterdam Treaty. This role of 'Mr CFSP' (or, as the case may be, 'Ms CFSP') has been added to the existing post of the SecretaryGeneral, who heads the Secretariat.

Past Secretaries-General of the Council Secretariat were senior diplomats in one of the member states before taking up their job in Brussels, but the political significance of the post experienced a quantum leap with the appointment, in 1999, of Javier Solana. Before joining the Secretariat, Solana had been Foreign Minister in Spain and Secretary-General of NATO, and as such is regarded as a political 'heavyweight'. His responsibilities were further extended when, later in 1999, he was also appointed as 
Secretary-General of the Western European Union, signalling the strengthening links and the partial merger of this organisation with the Council. Solana's seniority together with his experience in foreign affairs and defence matters adds substantially to the actorness of the CFSP: now there is a central authority to communicate common positions, negotiate on the EU's behalf with third countries and oversee the growing number of EU missions and interventions in crisis regions. Nevertheless, the emphasis in judging the significance of this new post must be on the potential for enhancing the EU's foreign policy capabilities. Much still depends on the political will among member states - often lacking in the past - to agree to common positions and subsequently to comply with these.

Javier Solana's experience as NATO SecretaryGeneral is significant also in the context of efforts to develop a dedicated EU role in defence matters. For decades, the 'security' aspect of CFSP had been treated sensitively in order to ensure that military issues would not appear on the agenda of the EU. This was in response both to internal constraints - the sensitivities of neutral or nonaligned member states - as well as to external relationships - the desire among most EU members to maintain a strong link with the USA in the framework of NATO. But in the late 1990s, in response to an Anglo-French initiative and in the wake of the Kosovo war, consensus was emerging among member states that the EU ought to have a military capability to conduct so-called 'Petersberg tasks' - military intervention in crisis areas for the purposes of peacekeeping, peace-enforcement or humanitarian assistance. The Helsinki Council in December 1999 spelt out the vision and the needs of such a military dimension of the EU. It implies not only the designation of up to 120,000 troops in the member states for use in EU-led operations, but also the 
build-up of military expertise in the EU's central institutions (Presidency of the European Union 1999).

In order to achieve this, a number of political and military bodies have been convened within the Council (Presidency of the European Union 2000). One new body, the Political and Security Committee, generally know by its French acronym COPS, is at the pinnacle of this development, bringing together the Political Directors of the national foreign ministries. Since 2001 COPS has replaced the previous Political Committee ( $\mathrm{PoCo}$ ) and now oversees not only the work of the CFSP working groups, but is also the body exercising political control over the EU Military Staff and EU Military Committee (Duke 2005). A further addition to the expanding security structures has come with the appointment, in the wake of the March 2003 Madrid bombings, of an EU Counter-terrorism Co-ordinator. The creation of a European External Action service, in effect giving the EU it's own full-blown diplomatic service by bringing together parts of the Commission and the Council Secretariat departments, strengthened through seconded officials from the member states, will be another quantum leap in this process. Even though the creation of this service is foreseen in the Constitutional Treaty, it is one aspect of it which may be realised in some form even without the ratification of the Treaty.

The emergence of the Council Secretariat as a political institution and the transformation of the SecretaryGeneral into a significant player in the development of CFSP could be expected to exacerbate existing rivalries with the Commission, given that institution's own role in the area of external relations. In this context it is worth mentioning that the relationship between Chris Patten, the EU Commissioner for External Relations in the Prodi Commission, and Javier Solana has, on the whole, been co- 
operative. Clearly, in the search for a coherent and effective conduct of the EU's foreign relations, encompassing external economic relations, humanitarian aid, CFSP and military intervention, co-operation between Commission and Council - both Secretariat and foreign ministers - is more important than ever. Their mutual dependence in managing the EU's external relations is encouraging and points to a stronger foreign policy partnership between Council Secretariat and Commission in the future - not quite the result that was to be expected from the longstanding efforts of member states to keep foreign policy matters out of the hands of supranational institutions.

In some ways, the idea contained in the Constitutional Treaty to create the post of an EU Minister for Foreign Affairs is an interesting solution to this issue. It dodges the issue whether it should be either Commission or Council Secretariat that has control over the resources in the external relations field. Instead continuing with the current practice that the Commission stays in charge of those foreign policy instruments that are more economic, traderelated and budgetary, and the Council Secretariat responsible for the more traditional diplomatic, security and military aspects, the Treaty proposed to square the circle by making a single individual - the new foreign affairs 'minister' - responsible for both. He or she (in fact it has already been decided that Javier Solana will be promoted to the job when it comes into existence) will then chair the GAERC Council, head the CFSP and security bodies in the Council structure, but also be Vice-President of the Commission. Such a solution certainly provides for easier recognition of who is in charge of EU foreign policy, but it may cause difficulties in establishing how the holder of this new post relates to the Presidents of the Commission and the European Council. 


\section{Conclusions}

The Council of Ministers operates on a number of different levels, and is embedded within a wider context of intergovernmental institutions. Its role remains central to European governance as the key channel for the representation of national and sectoral interests from the member states to the European Union. Interest representation has become more complex as the number of member states has grown, the range of issues has expanded and the negotiations involve questions of greater technical detail. In response to these developments, the number of sectoral Councils has multiplied and an extensive network of committees and working groups has evolved around the original meeting of foreign ministers which remains at the heart of the Council structure.

The expansion of competences and the growing number of arenas for deliberation in turn require greater coordination of Council business. In this respect, the Presidency and the European Council have become more important, but beyond co-ordination they have also provided welcome opportunities for member states to regain the initiative and a greater degree of control over the integration process.

But, as this chapter has sought to show, the evolution of the Council is also marked by some unexpected and arguably unintended consequences. Negotiations among ministers and officials is not just a oneway street of interest representation: frequent meetings and continuous deliberation among member state representatives also provide an environment for policylearning, cultural exchange, socialisation and even the transformation of allegiances. As such, the Council structure constitutes an important site for the establishment 
or growth of policy networks and other channels of interest representation which cut across the member states.

Most recently, the Council Secretariat has witnessed a boost, as new foreign policy and military bodies have been created and its head who is already the EU's High Representative for the CFSP, is designated as the future EU Minister for Foreign Affairs. The combined effect of these developments is that the Secretariat is being recognised as the core of the EU's ambitions in the diplomatic and security field. If these ambitions are being turned into reality, the Secretariat and the High Representative stand much to gain, but, given the past record of the EU in this field, there is also a case for caution. These are still very early days in the long-term endeavour to provide the EU with effective institutions for foreign policy and military intervention. From an institutional point of view it remains to be seen, in particular, whether the relationship between the Council Secretariat and the Commission evolves as one of partnership or rivalry in the management of the Union's external relations. In this context we have to see the proposal contained in the Constitutional Treaty, of a European foreign minister that would have had a crucial role in managing the external relations of both the Council and the Commission

The strengthening of the Secretariat illustrates the trend towards a greater degree of institutionalisation in the Council more generally. It demonstrates the dilemma national governments face as they ask the EU to perform additional tasks while also seeking to maintain close control over their execution. It may be that, by transferring powers to the Secretariat and the committee structure, governments have prevented the Commission from gaining further powers. Yet, in the process the Council itself has become 
more of a supranational body and the conglomerate of institutions now involved in the making of EU policy has become ever more difficult to hold to account.

In the early years of the new century, institutionalised intergovernmentalism has found new ways of responding to the dilemmas and challenges of European governance. The reality of enlargement, which has added several new challenges to the work of the Council (Bayer 2005), and the potential implementation of the reforms foreseen in the Constitutional Treaty, should that be ratified, will interact with this long-term trend towards greater institutionalisation. Internal changes such as the reduction of the national veto and the external challenges of an enlarged European Union will test the effectiveness and the legitimacy of these institutions. There may be testing times ahead, but the experience so far shows that member states are willing and able to adapt the Council to the changing demands of its environment. 



\section{Chapter 4}

\section{Tensions of European governance:}

politicised bureaucracy and multiple accountability in the European Commission

If the process of European integration has created an entity that is "less than a federation, [but] more than a regime" (Wallace, 1983), this is due to the set of novel institutions it has spawned. These institutions are different from state institutions: they operate in a political space in which institutions can neither rely on a common identity nor on claims to territorial sovereignty. Yet, European institutions are also distinct from the institutions of international organisations in having the capacity and the legitimacy to act relatively independently of Member States' assent. It is, above all, this distinction from traditional institutional forms that sets the politics of the European Union apart from both international relations and domestic politics. It is also the reason why the merit of studying the operation of European 
institutions lies in their wider significance for the understanding of the European project as a whole.

In this article institutional structures are viewed as the conceptual 'middle-ground' - between micro- and macrolevels of analysis - of integration. More specifically, European institutions provide the link between specific policy-networks and the overall evolution of the European Union. Taking such a perspective we are faced with, on the one hand, an extensive and detailed research agenda on European policy-making in its diversity of sectors and stages, and, on the other hand, a still unresolved debate about the general dynamics of the integration project. In this context, neo-institutional perspectives on European integration as recently advanced by some scholars (Bulmer, 1994, Cram, 1994, Peterson, 1995; Pierson, 1996) have a important utility: European institutions are studied not just with a view to their individual functioning, but also, and particularly, in order to develop a more systematic link between the insights of policy-analysis and of integration theory.

Together with the development of theoretical perspectives on institutional change, the past few years have also seen a marked rise in the empirical attention given to $\mathrm{EU}$ institutions. This is particularly true with regard to the European Commission (Edwards and Spence, 1994; Dehousse and Majone, 1994; Philip Morris Institute, 1995; Drake, 1995; Egeberg, 1995; George, 1995; Nugent, 1995; Ross, 1994; Cram, 1994; Grant, 1995; Cini, 1995; Mendrinou, 1996). This recent wave of writings on the Commission is ample evidence that the criticism made by Edwards and Spence, namely that "given its importance in the integration process ..., there has been a surprising dearth of academic or other study of the European Commission" (Edwards and Spence, 1994; p.1), is widely shared and being addressed. 


\section{A neo-institutionalist perspective on the European Commission}

The past decade has witnessed the formulation of such a "new institutionalist" research programme (see Evans et al., 1985; March and Olsen, 1984; Powell and DiMaggio, 1991; Thelen and Steinmo, 1991). As has been pointed out, this renewed attention to organisational factors in political life has taken very different forms (Koelble, 1995). More specifically, both reflectivist and rationalist strands of institutionalist thinking regarding politics and society have developed (Cammack, 1992).

These are 'new' perspectives in so far as they conceive institutions not simply as formal arrangements carrying out assigned functions in political, social or economic life, but are treated as reflections on the development of societal value systems and tensions within them. In other words, institutions exist in close relationship to the society, effectively linking the actions of individuals within their ambit to wider social processes. Such an understanding of institutions as mediators between individual action and structural foundations makes them a crucial arena for social change.

One way of operationalising such a neoinstitutionalist perspective is by focussing on the way in which "institutionalised contradiction" has become politicised (Friedland and Alford, 1992). Neoinstitutionalism, by searching for such instances of institutionalised contradiction and analysing their politicisation, seeks to study dynamic change - which is, after all, also the perennial puzzle of European integration. 
The European Union has had to accommodate a number of fundamental contradictions. Elsewhere dilemmas such as "uniformity v. diversity" (Stein, 1986) and "independence v. accountability" (Majone, 1994a) have been identified. Here two basic tensions of the integration process will be conceptualised. Their institutional expression links the internal dynamics of the Commission to the larger integration project. These tensions can be visualised as vertical and horizontal axes of a conceptual space within which the European Union as well as individual institutions can be located.

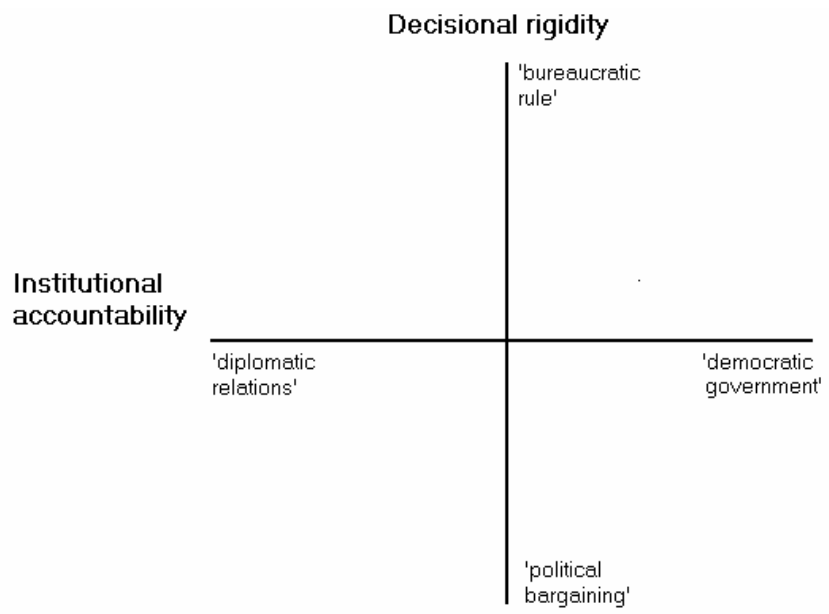

Figure 1 Inherent tensions of European governance

The horizontal dimension - to be called here 'institutional accountability' - describes the conflict between Member State control and direct accountability of the European institutions to the citizens at the other. The 
European project attempts to deal with this conflict through a hybrid organisation and a number of federal-type arrangements. The result for the Commission, a system of "multiple accountability", is the subject of second half of this article.

Another dimension of institutionalised contradiction ought not to be confused with this. This is the conflict not between collective and individual interests among the Union's membership, but the tension between the political and legal nature(s) of the Union system (Weiler, 1991). This tension has also been a major factor in the Commission's evolution (Coombes, 1970). On this second, vertical axis, the one extreme can thus be called 'politics', i.e. the nature of decision-making as an open-ended and largely unstructured process, whereas the other extreme is 'bureaucracy', i.e. the presence of a rigid, rule-bound and hierarchical environment for political action. This dimension is termed here 'decisional rigidity'.

If these two dimensions of conflict are combined in the above fashion, four broad organisational categories can be distinguished. The graph below illustrates how these two dimensions operate within the Commission, and what labels can be put to the organisational logics they produce: 


\begin{tabular}{|c|c|c|c|}
\hline \multicolumn{2}{|c|}{$\begin{array}{l}\text { Organisational Logics } \\
\text { within the European } \\
\text { Commission }\end{array}$} & \multicolumn{2}{|c|}{ Institutional Accountability } \\
\hline & & "Diplomacy" & "Democracy" \\
\hline \multirow[t]{2}{*}{$\begin{array}{l}\text { Decisional } \\
\text { Rigidity }\end{array}$} & "Bureaucracy" & $\begin{array}{c}\text { International } \\
\text { Secretariat }\end{array}$ & $\begin{array}{c}\text { Public } \\
\text { Administration }\end{array}$ \\
\hline & "Politics" & $\begin{array}{l}\text { Independent } \\
\text { Agency }\end{array}$ & Cabinet \\
\hline
\end{tabular}

Figure 2 Organisational Logics within the European Commission

Both dimensions describe inherent conflicts of the European project. They are inherent in the sense that without their presence the European project would not be what it is: as far as the horizontal, 'supranational-Member State' dimension is concerned, integration is neither expected to remain a solely intergovernmental affair, nor to lead to a state-like integrated structure. On the vertical axis, the Union institutions are neither solely political nor solely bureaucratic bodies - features of both organisational logics are present. The tension between collective and individual state interests, on the one hand, and the tension between open-ended, 'political' bargaining and a system of formal and informal rules are permanent features of the integration process. The very fact that there is no perspective for the resolution of these conflicts is what makes the European Union so distinctive. Continuous tension - sometimes captured in the "unity in diversity" slogan - is part of the very identity of an institutionalised Europe. 


\section{Decision rigidity: The Commission between politicisation and bureaucratisation}

It is a common reflex to view the Commission as a bureaucracy. In many ways, of course, the Commission does fulfil functions and appropriates roles comparable to bureaucracies in domestic systems. Regularly, the Commission acts as the extension of national bureaucracies. Indeed, the Commission has for many in Europe become synonymous with the very concept of 'bureaucracy'. But to treat the Commission, without as just another bureaucracy either disregards its exceptional circumstances or else implies a departure from established definitions of 'bureaucracy'.

To retain analytical value, 'bureaucracy' must involve, at the very minimum, aspirations towards ruleorientation and -coherence, hierarchical organisation, functional specialization, the development of standard operating procedures (SOPs). Such a definition in the Weberian tradition follows Pollit, who also notes that

[e]mpirically, it makes more sense to write of degrees of bureaucratization rather then to impose a 'black-and-white, 'is a bureaucracy/isn't a bureaucracy’ dichotomy." (Pollit, 1988: 159-160).

In this light, the Commission ought to be seen as more or less bureaucratic. The above parameters are therefore understood, not as final denominators, but merely as yardsticks for empirical analysis. This might seem obvious, but simply not starting with the ex ante assumption that the Commission is a bureaucracy is already a departure from the way in which the Commission is conventionally regarded.

What detracts from the bureaucratic element in the Commission's activity - what makes the Commission "less 
bureaucratic" than other bureaux - is the nature of continuous bargaining in the Union. The major fields of Commission activity - proposing legislation and supervising the implementation of decisions - are highly politicised tasks. In the EU systems, policies are not only subject to the extensive deliberations in the legislative phase, but are also bound to be re-negotiated when it comes to their implementation in different national contexts. In this system the Commission is a 'politicised bureaucracy', faced with a dilemma between its duty to develop and apply common rules and continuous political pressure for deviation.

This dilemma is with any bureaucracy, national or international. But the nature of much of the Commission's work - the overarching regulatory function it fulfils for the European Union, the large degree of symbolism that is often involved in EU decision-making, the continuing process of expansion of the EU's institutional framework, the ongoing process of 'constitutional reform' - has meant that numerous political forces take exceptional interest in the internal proceedings of the Commission. Having to manage the resultant clash between pervasive political interests and the rigidities of the acquis communautaire is what makes the Commission a such a special type of public administration.

There are a number of ways in which the issue of bureaucratisation $v$. politicisation of the Union can be tackled. A historical account, for example, would have little difficulty in identify different phases of the Commission's development. The more bureaucratic phase of the 'planner' Monnet, followed by the more political self-perception of the Commission under the 'diplomat' Hallstein. The end of Hallstein's reign saw a return to the bureaucratic nature of Commission activity, until Jacques Delors introduced new "leadership" and politicised the work of the Commission significantly (Drake, 1995; Ludlow, 1991). And the 
European Parliament's cautious response to the new Santer Commission and its 1995 programme (Jacobs, 1995) indicates the MEPs fear that there might be, in the phase of retrenchment after Delors' departure, a reversion to the bureaucratic mode. But, as Ludlow has pointed out, at least among the Commissioners, "there is a strong trend towards the appointment of politicians" (Ludlow, 1991: 89).

Even such a brief and cursory glance at the Commission's history indicates a number of salient points: there is not necessarily a linear development towards a more 'political', or alternatively, a more 'bureaucratic' Commission. There are, clearly, bound to be radical shifts in the way the Commission's role is seen as more political or more bureaucratic, and these changes over time are responses to internal as well as external impulses. At the same time it should be noted that there is always a degree of bureaucratisation and of politicisation in the Commission's work. The historical account of changing modes must therefore be seen as a change of emphasis rather than a complete switch: an indication that the internal 'equation' of political and bureaucratic forces has been reshuffled.

\section{Inter-departmental conflicts: The case of state aid control and regional policy}

The notion of "bureaucratic politics" is distinct from what we have called "politicised bureaucracy". The concept of bureaucratic politics has been employed in foreign policy analysis (Allison, 1971), comparative politics (Downs, 1967) and in previous studies of the Union (Peters, 1992). The focus of 'bureaucratic politics' studies is on competition and conflict between different administrative agencies or departments. 
Notwithstanding this distinction, politicisation in the Commission may well express itself in a pattern of 'bureaucratic politics'. Inter-departmental conflict in the Commission is usually being related to the conflict between sectoral interests that the respective DGs are seen to represent. Conflicts of sectoral interests within the Commission are, as a matter of course, to be expected. Yet, in line with the above argument about the general pervasiveness of bureaucracy-political tensions within the Commission, it is worth asking whether inter-departmental disputes can also result from different DGs finding distinctive answers to this dilemma. The assumption here is that one DG might find itself in more of a 'bureaucratic' mode of operation, and another more towards the 'political' end of the spectrum. As a consequence, when two such DGs have to cooperate on a matter of Union policy (as is frequently the case), they will find themselves at loggerheads.

A case study will illustrate this point. The dispute over the control of state aids policy has seen a major confrontation between DGs IV (competition policy) and XVI (regional policies). From the late 1980s, DG XVI began quarrelling with DG IV about the control of national regional policies (Wishlade, 1993; 1994). This dispute, and the need to resolve the differences, originated from both DGs serving notices to local, regional and national authorities that were diametrically opposed to one another. DG XVI would announce that a certain region qualified for Community aid from the structural funds, whereas DG IV would inform the same addressee that the granting of national or regional aid for the same area was prohibited. Regions were thus facing the absurd situation in which they were receiving state aid from the Community, but were being banned by the Community to grant such aid themselves. Wishlade's research has shown that this dispute affected more than 13 
per cent of the Union's population. 5.7 per cent of the EU population - the equivalent of the entire population of the Netherlands - were then in areas that received support from the structural funds, but were not - according to DG IV eligible for national regional aid (Wishlade, 1993). More recent data suggests that these inconsistencies are not being resolved (Marques, 1994) - indeed, since then enlargement has most likely contributed to a widening of the gap in area coverage.

DG IV has developed an active policy of evaluating national regional policies and frequently questioning sections of the national plans submitted to it. The legal framework for this was essentially a number of articles in the Rome Treaty and the accumulated case law of Commission and Court of Justice decisions. In other words, it was an area of Commission policy that was relatively flexible, and a change in Commission policy did not necessarily require support from the Council. The general thrust of the Single Act and the 1992 programme further empowered the Commission to pursue a pro-active role (Ehlermann, 1994; McGowan and Wilks, 1995). One legal observer has noted that in this development

the Commission combines, not only within the competition division, but within individual officials, the role of prosecutor and judge...[this] has left the Commission the master of its own procedural destiny (Brent, 1995).

In the context of the argument here this means that in the late 1980 s and up to the present the pattern of decision-making in the general field of competition policy has become less bound by the application of rules than by political bargaining. The practice in the field of merger control, which accounts 
for a significant part of the extension of competition policy in this period, was for DG IV to prepare a dossier which would then voted upon by the collegiate of Commissioner's. This process meant that decisions would be taken under political considerations rather than according to any objective criteria that might have been applied. 'Political' here stands for a number of things: left-right politics among Commissioners, different national positions (frequently mergers are seen as 'national' issues, since often 'national' champions are involved), and beyond this the general notion that decisionmaking is allowed, indeed supposed, to be subjective looking at each case on its own merit - rather than objective applying a common rule anonymously. Value-orientations, interests and resources are bound to guide the decisionmakers, Criticism and charges of political interference has been rife.

Yet, the point here is not to criticise or question the politicised nature of Commission policy in this field. Rather, it ought to be recognized that this pattern of decision-making differs significantly from that of other parts of the Commission's administration. In the present context we need to look at the way in which DG XVI has performed its functions in the same period. With the reform of the structural funds, which came soon after the ratification of the Single Act the Commission enlarged its role in the field of regional policy. The extent of this reform has been amply discussed elsewhere (Marks, 1992). Crucially, the structural fund reform has been marked by the passage of a rather high number of directives and regulations - a dense network of rules and stipulations that has had the effect of embedding DG XVI in a relatively structured relationship with administrative bodies on a multitude of territorial levels. Indeed, the very nature of the reform was to foreclose the freedom of action of national governments by way of instituting administrative procedures, regulations and multi- 
annual programming. As a matter of course, this new system, once established, would also foreclose the Commission's freedom of action. Essentially, with the reform of the structural funds the Commission adopted the role of a "guardian of rules and procedures" as much as that of a "big spender".

The difference, in terms of organisational reflexes, between DG IV and DG XVI ought to be clear. Both enlarged their roles significantly after the SEA, and both increased their relative weight, vis-à-vis the national authorities as well as within the Commission itself. But the growth of DG IV was based on doing away with rules, on opening up the decision-making to political considerations. The growth of DG XVI, by contrast, was based on the opposite: the creation of new rules, the definition of objective criteria and of agreed priorities for Union action, the imposition of procedures, and the closing of decision-making to political considerations.

In other words, DG IV has been socialized into a more 'political' and DG XVI into a more 'bureaucratic' mode of decision-making. Accepting that departmental action is at least in part guided by such general and underlying trends to its decision-processes, it is little surprising that in the 1990s DG IV and DG XVI should find it difficult to agree on a common approach to the control of state aids. Indeed, it can be seen as a paradigmatic case of the clash between the 'political' and the 'bureaucratic' organizational modes present in the Commission.

Doubtlessly numerous examples of this kind can be found. Not all will boil down to differing organisational logics of the relevant departments. In some cases micro- or macro-perspectives will retain their independent explanatory power: for example, the idiosyncrasy of individual decisionmakers or the capture of administrative units by specific 
interests often results in interdepartmental conflicts. Ross (1994) provides ample evidence of this happening. Internal conflict in the Commission is therefore not always an instance of institutionalized contradiction. But clearly, examining inter-departmental conflict it is one way of identifying tensions between different organisational logics.

\section{Collegiality, hierarchy and the role of cabinets}

If the above discussion of inter-departmental struggles can be seen as the horizontal expression of the problem of decisional rigidity in the Commission, then there is also the incidence of vertical conflict of this kind. In a way, this is the most immediate and obvious case of politics $\mathrm{v}$. bureaucracy in the Commission. The 'political level' of the Commission - the collegiate comprising the President, the two Vice-Presidents and the other, currently 17, "Members of the Commission" and the 'bureaucratic' body of the Commission's 15,000 officials are practically two different institutions: in domestic systems one would quite naturally distinguish between the cabinet - providing executive government and political leadership in the political system - and the civil servants in the ministries - providing the administrative support necessary to prepare and carry out cabinet decisions. In the EU system, such a distinction between cabinet and administration is not that easily made, in part because the Council is, after all, a collectivity of ministers that would not want to see the Commission encroach on its status. If anything, collective leadership is provided by the "dual presidency" of Commission President and Council Presidency. Apart from this feature there is essentially no clearly definable cabinet or executive government in the EU system. 
As a result of this distinctive situation, the institution "Commission" stands for two quite different 'creatures': on the one hand, the collegiate of Commissioners, who are politicians, and, on the other, an organization staffed by civil servants, who constitute the core of the EU's bureaucracy. This fusion of 'the political' and 'the bureaucratic' in the very nature of the Commission is what lies at the heart of much of the difficulty in dealing with "Commission decisions" or "Commission policy". It is not as easy as in domestic systems to identify whether Commission activity stems from decisions made in the political domain - by the Commissioners - or whether it results from standard administrative responses generated by civil servants. In domestic systems, for example, there is the distinction between statutory measures, cabinet decisions and legislative acts, indicating the institutional level at which a policy is made. In the EU system, the distinction between "regulations", "directives" and "decisions" is not a helpful guide, as each of these can be issued by Commission, by the Council or by the Union's institutions collectively.

Within the Commission, the political-bureaucratic interface is managed by the cabinets, the personal staff of each of the Commissioners. They are responsible for monitoring, on behalf of their Commissioner, the activity of the other departments in the Commission (Ludlow, 1991: 9394; Nugent, 1995b: 89). In this way, cabinets are performing a crucial function in preparing the weekly Commission meetings and facilitating the principle of collegiality - the shared responsibility Commissioners undertake for the activity of the institution as a whole. Cabinets, in enabling individual Commissioners to control developments outside their own department, are contributing to horizontal integration within the political domain of the Commission, allowing it to function like a national cabinet. 
This is complementary to the work of the secretariatgeneral, which, under the responsibility of the Commission President, is charged with ensuring the overall consistency of the Commission's output. Yet these two institutions, the secretariat-general and the cabinet structure, are in a complementary as well as competitive relationship. As a result, there are two circuits of horizontal coordination inside the Commission: both the chefs de cabinet and the DirectorGenerals and Secretary-General meet once a week to coordinate Commission policy - an arrangement which can also contribute to the development of different agendas, thus amplifying the political-administrative split within the Commission.

Cabinets are also gate-keepers to the Commissioner's desk. As such they constitute the link between the bureaucratic Commission and the political Commission. In this role, they ideally provide the Commissioner with information regarding the state of affairs in the various DGs under her or his responsibility as well as communicating the political decisions made to the officials within the DGs (Donnelly and Ritchie, 1994). As was mentioned earlier, this is a sensitive task. Within individual DGs there is often little appreciation of the work done in other DGs. The frequent change of Commissioner and their cabinets, together with the continuity of the staff on the administrative level, contributes further to the lack of integration between these two domains.

Thus there are occasional allegations from DG officials that cabinet members mismanage this sensitive gatekeeping function. Top-down, this might mean that cabinet members send instructions to, or ask files from, individual desk officers, neglecting the hierarchical organization of the DG and consequently ignoring the director-general, division heads, etc. Bottom-up, this would stand for cabinet members 
blocking access for desk-officers and Director-Generals to the Commissioner, filtering out matters which they consider politically unwarranted. Such occasional charges of 'political interference' in the work of DGs is another example about the way in which principles of administrative hierarchy and political agenda-setting conflict within the Commission. What this demonstrates, at any rate, is the crucial role that cabinets perform at the interface of the political and the bureaucratic logics inside the Commission.

\section{Member State influence, nationality and Comitology}

As indicated at the outset, the Commission is faced with a second dimension of internal contradiction, that of having to account to two rather distinct sets of interests. In the Union's legislative process, this means Council and Parliament. But, in a wider sense, these institutions stand for the Member States and for the citizens of the Union, respectively. These are ultimately the 'constituents' holding the Commission to account.

The representation of Member States' interests in the EU system is not confined to the national representations, COREPER and Council of Ministers. Member State influence is pervasive in other institutions as well. Within the Commission, an obvious sign for this is each Member State having 'its' Commissioner(s). Their role is essentially twofold: on top of their official, sectoral responsibilities they also function as the most senior link between the Commission and the respective national political circuit. Usually, they are members - and appointees - of the major parties in their Member State and continue some involvement with national politics after becoming Commissioners. Frequent trips to speak before (and perhaps to lecture) 
national audiences are common. Again, the metaphor of gatekeeping is perhaps most useful: Commissioners are an easy and efficient way for the Commission to maintain a link with Member State governments and domestic political systems. They will know what legislative proposals are politically acceptable in national capitals, while at the same time being in an ideal position to communicate to elites on the national circuit the requirements of efficient European policy-making.

Yet the unwritten rule that Commissioners also represent Member States - and, by association, Member States' interests - inside the Commission is only the tip of an iceberg of Member State influence inside this supposedly supranational institution. We can look only briefly at a few examples of the way in which the Commission is also an intergovernmental body. On the individual level, for instance, most Commission officials are not just nationals of one of the Member States, but also come from an education, administration and political system that is profoundly national in orientation. Those entering the Commission with a genuinly European educational formation, like those coming from the College of Europe, the European Institute of Public Administration or the European University Institute, are in a small albeit growing minority. Research on the international organisations indicates the gulf between the theory of a "neutral" international civil service (Hammarskjöld, 1962) and the pervasiveness of national identity (Wilterdink, 1990) among the staff of international organisations, even though there this identification tends to be lower than in the wider public. In the end, there is a gulf between "the myth and the reality" of an international civil service (Weiss, 1982).

There is little empirical work on the identification and socialization of Commission staff, but what there is confirms the perspective of inherent tension that is advanced 
here. On the one hand, Commission officials are 'special' for a number of structural reasons associated with the institution: [T] he Commission's officials' typical motivational structure is quite different from that of the average national government official...

[T] he Commission recruits from people who are highly motivated, risk-oriented, polyglot, cosmopolitan, open-minded and innovative...From the beginnings in the 1960s to the present, it has indeed been officials of a special type who chose to leave the relative security of their national administrations to go to Brussels to do there a wellpaid but extremely challenging job. These people mutually stabilize their motivational structures with a distinct esprit de corps" (Eichener, 1992).

On the other hand, there remains the link with national administrative cultures and systems, something which has been the subject of a number of recent studies (Egeberg, 1995; Bellier, 1995; Christoph, 1993). Egeberg, for examples, finds that 60 per cent of respondents in the Commission state nationality as important for networkbuilding. Considering how important policy-networks are the making of European public policy (Richardson 1996), this finding - in what is usually considered a supranational institution - is remarkable, even if only 23 per cent of respondents consider nationality as guiding their decisions. Nationality still matters, if only to a limited and perhaps declining extent - this is the credo of such investigations. Even though the Commission is a modern, progressive and innovative organisation, its staff maintains allegiance to national identities and the routines of cultural and linguistic affinity. 
Such national identifications on the individual level, among Commissioners and officials alike, sometimes become institutionalized in units, divisions and even whole DGs. Senior Commission appointments, for example, have always been made on the basis of national 'quotas', a practice - referred to by insiders as "parachuting" - so pervasive that in 1993 even the European Court was provoked into action on this matter (Nugent, 1995b: 90). There are also frequent allegations that one or the other DG has been "captured" by a Member State. Returning to the case of competition policy, for example, it is interesting to note that in the past decades DG IV has had German Director-Generals. (West) Germany's specific interest in a European dimension to competition policy was demonstrated by the fact that the Bundestag passed the major pieces of domestic German anti-trust legislation on the same day on which it ratified the Rome Treaties. Subsequently, it has been recognised within the Commission and beyond that competition policy has been a special interest of the Federal Republic. There is also the familiar complaint - in particular from the UK - that the Commission on the whole is based on a francophone blueprint of administrative organisation, and that this disadvantages applicants or entrants from Member States with different administrative cultures. This charge relates neatly to the view that the whole Union was initially designed like a "French garden" (Holm, forthcoming).

Further structural conditions contribute to the phenomena of 'quasi-intergovernmentalism' within the Commission. Much of the above concerned fonctionaires, i.e. officials with lifetime employment guarantee, pension rights, special access to the European Court, etc. - in other words, people receiving an exceptional treatment that ought to enhance their sense of allegiance with the European project. But the Commission services also consist of a large share of non-permanent employees - temporaires, stagiaires, and, 
crucially, national civil servants under secondment to the European institutions - many of whom are returning to, or entering into, national administrative systems after their time in Brussels. Clearly this has detrimental effects on their identification with the European project and, as a corollary, on the way in which the Commission as a whole can understand itself as a European civil service.

Again, hard data is lacking on the pattern of secondment, but it seems safe to suggest that the share of Commission staff that is not permanently employed is analytically significant. Seconded staff are fulfilling a double role in bringing national administrative expertise into the Commission, and communicating European processes back to their home systems. The crucial question for our purposes here is whether they generate more to the 'Europeaness' of national systems - the "going native in Brussels" syndrome than they contribute to the 'quasi-intergovernmentalism' of the Commission services - constituting a "fifth column". What effects this situation has on the Commission can only and ought to - be determined empirically. Clearly we are dealing with a reciprocal relationship which does not leave the Commission untouched. It is fair to assume that such linkages to officials' national 'constituency extend beyond the purely administrative realm into the network of policy communities - involving scientific experts and interest groups as well as national officials - which are so important in the agenda-setting stage of European policy-making (Richardson, 1995).

Finally, the "Brussels Eurocracy" is not just the Commission as such, but also the intricate system of advisory, regulatory and preparatory committees that surround the Commission. These are generally made up of 'national experts' in a number of highly specialized fields of policy-making as well as Commission staff. These 
committees are explicitly meant to safeguard Member State interests in those phases of the Union's policy process which are traditionally the core of Commission competence, namely the drafting of legislative proposals, the implementation of policy and the enforcement of compliance. These spheres of public policy-making lie outside the reach of the Council of Ministers, but rising awareness of the significance of agendasetting and implementation has meant that Member States have sought to regain direct influence in these matters. As a result, there has been the exorbitant growth of a network of thousands of committees of national and Commission officials - the structure that has come to be called comitology. These committees are not the 'ornaments' that their counterparts sometimes are in domestic administrative or parliamentary systems often are; their power in the making of European policy is real (Eichener, 1992; Joerges, 1994; Buitendijk and van Schendelen, 1995).

Arguably, it is the density and the extent of this intermeshing transnational committee structure which lies at the heart of the accountability problem of the European Union. The dilemma here is that while comitology structures aim at making the Commission more accountable to national governments, the complexity and the lack of transparency comitology makes it immensely difficult for 'European government' to account to citizens.

The above pointers to patterns of Member State influence in the Commission's political and administrative system - nationality, secondment and comitology - should not be understood as a critique of national 'meddling' in a supranational institution. The absence of comprehensive data prevents, in any case, a judgement on this matter. The argument here is simply that - to the degree to which the European project on the whole maintains aspects of intergovernmentalism - the Commission's organisational 
development also reflects the need of being accountable to national governments and the collective interests of the Member States. Ludlow has discussed the Commission's future in terms of legitimacy and efficiency (Ludlow, 1991). In the light of the above discussion, we can see that the Commission's 'quasi-intergovernmentalism' is also a response to legitimacy and efficiency problems. The absence of a broader public identification with the European project (Smith, 1992) as well as the need to manage indirect policyimplementation and to combat non-compliance (Somsen, 1995; Mendrinou, 1996) compel the Commission to remain sensitive to Member State interests.

\section{Multiple accountability: The Commission between states and citizens}

Much of the above is unbalanced, emphasising the degree to which the Commission is an intergovernmental organisation. This one-sided account was intended to redress the balance with respect to a body of literature which regularly treats the Commission as a purely supranational organisation. Therefore, the account of Member State influences in the Commission is given here only to show that the Commission also exhibits intergovernmental traits. In a similar vein, yet in the opposite direction, Wessels has convincingly argued for a recognition of the supranational nature of the Council of Ministers (Wessels, 1991).

The Commission does, of course, have strong supranational features. This is demonstrated by its 'special relationship' with the European Parliament, which has become much more salient in the period since the SEA (Westlake, 1994) and which has climaxed in the parliamentary hearings of prospective Commissioners that 
were held before their investiture in January 1995 (Jacobs, 1995).

But the Commission has also spent much time and energy in recent years trying to by-pass national governments and to reach out directly to the groups and sectors that are specifically concerned about Union legislation. Meetings between Commissioners, Commission officials and interested parties (firms, professional associations, trade unions, local and regional governments, lobbyists, political parties, pressure groups, etc.) have mushroomed (Donnelly, 1993). In some cases - the European Round Table of Industrialists, the European Environmental Forum and the Committee of the Regions are prime examples - the Commission's regularised contacts with 'third parties' have even become formally institutionalised. As a result, the Commission has gained the institutional standing of a "broker": access to specialised knowledge present within domestic systems combined with the ability to gauge the political acceptability of legislative proposals independently of national governments (Mazey and Richardson, 1994). In this manner, using its close relations with these intermediary bodies, the Commission has also attempted to closer to move closer to the citizen.

After Maastricht, when during the difficult ratification process it become clear that the functional nature of the European project of the 1980s had disregarded the need for popular support, all EU institutions sought remedies to the democratic deficit. In the run-up to the 1996 Intergovernmental Conference, the Reflection Group has concerned itself at length with ways of making the Union more accountable to the citizens of the Union (Council Presidency, 1995).

The Commission, in particular, felt the need to respond to criticisms about technocratic governance. An 
elaborate programme of greater openness, transparency and subsidiarity has been the result (European Commission, 1992a; European Commission, 1993; European Commission, 1994b). Part of this debate are proposals for the introduction of an 'Administrative Procedures Act' - similar to US practice - which would provide firms and individuals with greater certainty about the Commission's administrative responses. (Dehousse et al., 1992). The same holds true for attempts to structure the access of outside interest representations vis-à-vis the Commission (European Commission, 1992b).

All this goes to show that the development of a direct Commission-public relationship is in full swing. The various channels - European Parliament, intermediary social groups and organisations, access to, and certainty about, administrative procedures within the Commission - are combined attempts at making the Commission more accountable to citizens. But, as the discussion of comitology has emphasised, this is not an easy process, and the Commission still has a long way to go before citizens will be able, in any meaningful way, to hold it to account.

In practice, we see very often how the Commission is still torn by contradictory reflexes. In some instances, it resorts to 'diplomatic' responses (vide the difference in Commission and EP reactions to the recent French nuclear test series in the Pacific). In other cases the response is to search for dialogue with social groups and other domestic actors, and in yet other fields the Commission actively seeks closer relations with national administrations. With respect to the latter, the general tendency towards administrative convergence in EU Europe (Burnham and Maor, 1995) as well as the learning curve of actors involved in multi-level cooperation makes this an ever more normal working relationship. 
The Commission of the 1990s, whatever other problems it might face, is clearly wedged between, on the one side, the assurances and commitments it has to give national governments and, on the other, the need to respond to the wider debate about its public accountability. In this context, it is no little irony that as a fall-out of the Maastricht Treaty's negative reception in the ratification stage, the Commission had to respond to the specific requests from national governments while at the same time having to address public complaints about the 'democratic deficit'. This is ironic because, as this article has tried to show, the aims of increased recognition of national interests and an extension of democratic procedures are largely contradictory. Forcing the Commission to respond simultaneously to both means to amplify the institutionalized contradictions it has to resolve.

One attempt at addressing, if not resolving, this particular contradiction has been the subsidiarity agenda. Pushing subsidiarity has made it possible for the Commission to be seen as appeasing both Member State concerns about the apparently uncontrollable growth of Union regulation (Dehousse, 1994) and the perception among the wider public that the Union politics have lost touch with people's concerns. Consequently, the Commission has been keen to appear as active in reducing the number proposals for European legislation (European Commission, 1994b). Apparently, for a Commission faced with the contradictory nature of multiple accountability in the post-Maastricht phase, subsidiarity has a utility that is much beyond its limited inherent value (Dehousse, 1992; Christiansen, 1997). 


\section{Conclusion}

This article has sought to demonstrate how a focus on institutionalized contradiction, based on a neo-institutionalist approach to EU politics, brings salient features of the European Commission to the fore. The very fact that most of these appear under-researched is an indication that the model developed here points us in interesting directions. Issues like the origins of interdepartmental conflicts, the role of cabinets, the extent and the effects of seconded employment, the salience of nationality, the pattern of comitology and the provision of administrative transparency are being addressed by recent or ongoing research projects. The answers produced by these empirical projects will provide important clues to an improved understanding of the past and future development of the Commission.

Towards this purpose, the article has mapped out the complexity of the Commission, trying to steer away from simplistic notions about its "role" or "function". At the very least it has been shown that it makes little sense to look at the Commission through static institutional models. By contrast, a variety of contradictory organisational logics 'bureaucratic', 'political', 'diplomatic', 'democratic' - are at work within the Commission. To identify and classify these is the value of a neo-institutionalist approach. If this article has indicated how a neo-institutionalist research agenda on the European Commission ought to look like, then future empirical research will have to investigate in greater depth the specific issues that have come to the fore. 



\section{Chapter 5}

\section{The General Secretariat of the Council of Ministers*}

Influence does not equal formal powers. The European Union is rich in examples of institutions which, in the absence of formal powers, nevertheless manage to bring significant influence to bear on the policy-making process. Often they do so through a direct link to organised interests, the ability to generate public debate and the resultant impact on the policy-agenda of the European Union. The Commission is, of course, the prime example of an institution that has significant influence over the EU's policy-process through its ability to set the agenda, even though it lacks in most policy-areas the formal powers to ultimately take decisions.

One might say that these examples demonstrate that, under certain conditions - for example in the absence of

* This article is in part based on interviews conducted with officials in the Secretariat of the Council of the European Union, the European Commission and the permanent representations of some member states. The author is grateful to those officials who have provided insights and information into the work of the Council Secretariat. 
formal powers or when interests do not have direct, institutional or informal access to the decision-making bodies - influence may be a consequence of an institution's ability to 'make noise' - to bring certain issues to the attention of organised interests, the political press or the wider public generally, and to rely on any public pressure arising to influence the institutions formally taking decisions in the desired manner. It is a strategy with uncertain effectiveness, depending as it does on a number of degrees of separation: Will organised interests or the wider public actually react in the anticipated (and desired manner)? Will the issue be covered by the media? Will 'public pressure' be sufficient to influence the legislative process, or can it be ignored by the decision-making institutions?

Such questions are amplified in the case of the European Union, where formal decision-making takes place in arenas which are often regarded as being distant from the citizen, and where any public pressure is refracted through the prism of (at least) fifteen different national publics, communicative spaces and political cultures,. However, despite (and sometimes because of) these peculiarities of the EU system, 'making noise' remains an option for influencing decisionmaking in the European Union, and one that is used frequently by different political actors, with varying degrees of success.

Against this background of the political potential of 'noise', the General Secretariat of the Council of Ministers is an oddity: while it lacks formal decision-making powers, its officials have eschewed 'noise' and despite (or because of?) that stratggy developed an important role in different areas of EU policy-making. To the extent to which the Council Secretariat influences EU policy-making, it is a distinctly quiet influence. This makes the Council Secretariat a very interesting case in this volume's analysis of 'unelected 
legislators': not only does the Secretariat constitute a prime case of the 'unseen hand', but it is also a case of the 'hushed voice'. Rather than seeking the high-profile exposure of media campaigns, frequent speeches and the like, the Council Secretariat has relied on working in the background and giving direct advice to ministers, ambassadors and other member state representatives.

This article seeks to shed some light on what is generally a not very well-illuminated corner of the EU's institutional architecture. After a general overview of the Council Secretariat's role in the EU, it looks in greater detail at its involvement in the ordinary, first pillar policy-process, the process of treaty reform and decision-making in CFSP. A concluding section then examines the current and future challenges facing the Council Secretariat in the light of its recent development.

\section{The Council Secretariat: From Administrative Obscurity to Institutional Fame}

The Council's General Secretariat may not be an institution in the formal sense of the EU treaties, but it is quickly becoming a key player in the institutionalisation of European governance. Its long-standing role has been that of providing the Council of Ministers with central administrative services ${ }^{1}$. It facilitates the meetings taking place within the

1 For a general discussion of the organisation and the role of the Council of Ministers see M.Westlake The Council of the European Union (London: Catermill, 1995), F.Hayes-Renshaw and H.Wallace The Council of Ministers (London: Macmillan, 1997); .P.Sherrington The Council of Ministers - Political Authority in the European Union (London: Pinter, 2000)), and T.Christiansen 'The Council of Ministers: The Politics of Institutionalised Intergovernmentalism', in J.J.Richardson (ed.), The 
ambit of the Council, in other words the meetings of the various sectoral councils, but also of key committees and the myriad of sub-committees and working groups which prepare the decision-making of Coreper and ministerial councils ${ }^{2}$.

There are thousands such meetings in the EU's legislative cycle, and managing the mere logistical exercise of providing meetings rooms, printing and disseminating documents, maintaining meeting schedules and providing interpreting, minute-taking and other support services is no mean feat. At one level, the Council Secretariat constitutes a "dignified conference centre", as one participant has called it. However, it is clearly much more than that. While servicing Council meetings has always been a core task, it is neither the purely technical activity it may appear to be at first sight, nor is it the only responsibility of the Secretariat.

In fact, the 'support' of the Council includes highly political matters. These include providing legal and political advice to the Council generally, and to the Presidency in particular; legal representation of the Council in cases before the European Court of Justice; assisting the Presidency in the taking of minutes in Council meetings, the setting of meeting agendas and the running of meetings; helping of Commission and Presidency in the search for compromise in Council decision-making; maintaining regular relations with

European Union - Power and Policy-making (2nd ed.) (London: Routledge, 2001), pp.135-154.

2 These include, for example, the Committee of Permanent Representatives (COREPER), the Political Committee (political directors of national foreign ministries, the Article 36 Committee (the former K4 Committee) (meetings of senior justice and home affairs officials), the 'Article 133 Committee' (member state representatives shadowing the Commission's conduct of international trade negotiations). 
the Commission and the European Parliament in joint management of the legislative process.

This involvement of the Council Secretariat does not just apply to the day-to-day policy process of the European Union, but also to the running of European Council meetings and the - increasingly frequent - revision of the treaties through Intergovernmental Conferences. Just as with secondary legislation, the Council, The European Council and the Presidency also rely on the legal, administrative and political expertise of the Council Secretariat when it comes to the making of primary EU law. The IGC's 'conference secretariat' is staffed by the Council Secretariat and provides essentially the same services to the IGC as it does to the Council proper.

The potential, indirect influence of the Council Secretariat in the legislative and treaty reform processes has always been a feature of its role in the EU's institutional structure. More recently, the acquisition of substantial executive responsibilities has fundamentally changed the nature of the Secretariat. From being essentially a small bureau providing logistical support, legal opinion and political advice, developments in the areas of justice and home affairs, and, in particular, foreign and security policy and have turned the Secretariat into a sizeable, executive agency in its own right.

The past decade has witnessed an unprecendented growth of the Council Secretariat as it acquired new tasks, responsibilities and resources. This included the take-over of three, previously independent secretariats. As a result of the Maastricht Treaty the 'EPC secretariat' which had been established in the 1980s to facilitate liaison between national foreign ministries as part of the European Community's European Political Co-operation - the fore-runner of the CFSP - was integrated into the Council Secretariat. The so- 
called Schengen Secretariat dealing with the exchange of information in the area of asylum and immigration policies of the Member States was incorporated after the ratification of the Amsterdam Treaty. Most recently, parts of the responsibilities of the secretariat of the Western European Union - the defence alliance of the European NATO members - were taken over by the Council Secretariat. In addition, there has been the creation of a CFSP planning unit and of the EU military staff. Most significantly, the responsibilities of 'High Representative for the Common Foreign and Security Policy' have been added to the post of Secretary-General. The fact that, with the appointment of former Spanish foreign minister and Secretary-General of NATO Javier Solana, the first holder of this position was not an administrative, but a senior political appointment demonstrates the step-change which has taken place in the Secretariat. The day-to-day running of the Council Secretariat has therefore been left to the Deputy Secretary General, a post currently held by the former French Permanent Representative, Pierre de Boissieu ${ }^{3}$. Both Solana and de Boissieu have demonstrated the potential independence of their positions by making public statements that have been highly critical of Member States ${ }^{4}$.

As a result of these developments, there has been a substantial growth in the numbers of staff working in the Council Secretariat, much greater diversity in terms of the sectoral policies covered and an increase in the share of seconded national officials as part of the overall workforce.

3. See European Voice (1999c) 'Master of his brief', 9 December 1999 and European Voice (2000a) 'De Boissieu's surprise intervention', 30 March 2000 for details of his career and political influence.

4. See Financial Times (2002) 'Solana attacks decision-makers', 12 March 2002 and European Voice (2000b) 'Top official attacks the way governments conduct EU business’, 6 April 2000 
This in turn, and in line with the iron laws of administration, has required greater attention to issues of internal governance. The arrival of staff from what were previously different organisations (in particular the Schengen Secretariat, the EPC Secretariat, and, most recently, the WEU Secretariat) did cause some ripples in an administration that had remained largely unchanged for decades 5 . Integration across the different types of staff permanent and seconded; legal, diplomatic and military - is proving difficult.

This brief overview of the responsibilities of the Council Secretariat indicates that it plays a limited, but central, role in the current phase of the EU's evolution. Beyond its traditional contribution to the search for compromise agreement in the legislative process, it is also at the heart of the proceedings in treaty reform and at the forefront of the evolution of the Union's foreign, security and military policies. The subsequent sections will briefly elaborate on these three key responsibilities of the Council Secretariat. While looking across these different areas, it may be useful to keep in mind that 'influence', in the way it is understood here, relates to the capacity of Council Secretariat staff to have an impact on EU decision-making. This concerns first andf foremost the legislative process, but also includes a recognition of the relevamce of 'soft law' in the European Union, and thus on the degree of influence the Council Secretariat has had on that. This latter aspect of the Secretariat's influence is particularly pertinent with respect to the second and third pillars, while the former clearly

5. See, for example, European Voice (2000c) 'Shake-up of staff causes friction in institutions', 12 October 2000, European Voice (1999a) Staff dispute risks delaying EU reform', 1 April 1999 and European Voice (1997) 'Senior official criticised over recruitment', 20 March 1997 
matters most in the context of the legislative process in the first pillar.

\section{Quiet influence: the Council Secretariat's role in the EU Policy Process}

The Council Secretariat's role of assisting the Presidency and providing legal and other assistance advice facilitate the influencing of Council decisions, albeit in a subtle way and within a narrow policy-space. On the whole, the Secretariat is limited to reacting to the policy-proposals and the wider agenda emanating from the Member States and the Commission. If and when it has tried to drive a certain agenda itself, success has been limited. However, once proposals or draft legislation enters 'the house', as it were, the Secretariat does have opportunities for political influence.

Any such influence depends on numerous factors. An important one is the relationship between the Secretariat and the Presidency of the day. Different models have been experienced in this respect, but the common practice (especially for the smaller Member States) is to leave much of the organisation of Council business in Brussels, and therefore in the hands of the Council Secretariat staff. With a Presidency usually concentrating on a small number of petprojects, the management of the vast majority of Council business remains the task of Secretariat. This provides opportunities, for example, to prioritise certain agenda-items over others or to suggest changes to proposals in the light of legal opinion.

It is important to recognise that such influence occurs within the confines of what a Presidency as well as 
the member states generally, permit. There is therefore no platform for radical changes, but rather for tinkering with the detailed and complex matter of policy-proposals and draft directives. Then again, in much of what the European Union is engaged in, the devil is in the detail, and even minor changes of wording in legislative texts can have significant political implications ${ }^{6}$. However, if a Presidency decides to 'take over' micro-management of the EU's policy-agenda then the influence of the Secretariat is curtailed. But this is a strategy which insiders consider to lead to less than optimal results ${ }^{7}$.

Given the way in which the nature of the Presidency determines to a large extent the Council Secretariat's opportunities for influence in the policy-process, it is necessary to expand a little on this. As many observers and practitioners have recognised, the six-monthly term of any Presidency is actually very short - too short to properly engage with the detailed policy-agenda across the whole range of Union policies and provide consistent leadership in the decision-making process. The consequences of this state of affairs are, first, periods at the beginning of each Presidency when the Member State in question is still feeling its way in many of the areas of EU policy and, second, inconsistencies across the policy-areas depending on each Presidencies priorities and preferences. In other words, it is not just the choices made by each individual Presidency, but also the structural feature of charging a rotating, shortterm Presidency with important leadership tasks in the

6. See European Voice (2000d), 'A calculated summit for Chirac's man', 21 December 2000, for an illustration of the potential influence of Council Secretariat officials

7. See M,.Gray and A.Stubb 'The Treaty of Nice', in W.Wessels and G.Wiessala (ed.), JCMS Annual Review (Oxford: Blackwell, 2001). 
Council that governs the influence of the permanent Secretariat.

Another important qualification in discussing the Council Secretariat's influence is the need to cultivate relationships with the EU's more openly 'political' actors, whether this is the European Commission, Coreper or individual member states. The Commission, in particular, is a candidate for close co-operation in the policy-process. Council (and therefore Council Secretariat) and Commission are often regarded as rivals, but in fact there are frequent occasions where their relationship is better characterised as a division of labour ${ }^{8}$.

When legislative proposals reach the Council working groups, the Commission often finds itself in a contradictory position. On the one hand it seeks to advance its own proposal, on the other hand it expected to mediate between differing views in among the member states. However, the Council Secretariat, in 'advising' the Presidency on how to run a particular meeting, may be in a much better position to mediate different positions and to assist the search for a compromise. Thus, mediation and search for compromise can be greatly assisted by the cooperation and the exchange of information on the positions taken by national delegations between Commission and Council Secretariat staff.

In this context one should also bear in mind the need for Commission and Council to co-operate with respect to the Union's comitology structures. In areas where Member

8. For an examination of the evolving relationship between Commission and Council Secretariat, see T.Christiansen 'Interinstitutional Relations and Intra-institutional Politics in the EU: Towards coherent governance?', Journal of European Public Policy , Vol.8, No.5, (2001), pp.747-769. 
States delegate executive responsibility to the Commission, committees are the chosen method to supervise the Commission's execution of these delegated powers. In an area such as trade, where the Commission is negotiating multilateral agreements on behalf of the Union, the Council issues the negotiating mandate and monitors the Commission's conduct through a specially convened committee (Art. 133 committee). Formally it is again the Presidency that takes the lead in shadowing the Commission, but effectively it may often be the task of Council Secretariat staff to monitor the Commission and brief the Council on the progress of negotiations.

In sum, the Council Secretariat does have a distinct, albeit limited, role in the EU legislative process. Its influence in first pillar matters is dependent on the space provided by the Presidency, the tactical alliances which can be struck in the context of particular committee, Council or European Council meetings and the nature of the legislative proposals on which deliberations in the Council are based.

\section{The Council Secretariat and EU Treaty Reform: Institutionalising Constitutional Politics}

The making of secondary EU legislation takes place in a highly institutionalised context. Treaty revision, on the other hand, is traditionally seen as rather unstructured, an occasion for Member States to confront one another with conflicting views about the future development of the integration process, and the eventual achievement of agreement on treaty reform as a result of intense bargaining. While this view of treaty reform is not necessarily wrong, it does only provide a partial perspective on this feature of European integration. Treaty reform has over the past two decades 
become a permanent feature of the integration process. It is not a rare occasion to revise the treaty, nor even a series of events, but a quasi-constant process of constitutionalisation where each instance of treaty reform already provides the starting point for the next. It is also a process which has become increasingly institutionalised, with numerous rules being laid down as to the working methods of negotiating treaty reform. The latter is a development in which the Council Secretariat has had no small part ${ }^{9}$.

Arguably the most important aspect of the Council Secretariat's role in IGCs is the provision of legal advice to the conference generally, and to the Presidency in particular. The Council Secretariat's legal service is designated at the legal service of the conference, thus gaining a privileged position, if not a monopoly, with regard to the interpretation of new or revised legal articles being discussed. This puts the legal staff of the Council Secretariat in a crucial position: in the absence of recourse to judicial review of individual aspects of the negotiation results, the 'legal advice' of the Council's legal service on proposals for draft articles is authoritative and can therefore constitute a constraint on the possibilities for treaty reform.

The Council Secretariat's acquisition of this role as the provider of legal advice to the IGC may seem like a 'natural' choice of governments, but matters are probably less innocent than that, given that such decisions concerning organisational detail are drafted by the Council Secretariat itself. The SEA IGC, convened under the influence of Delors' preferences for a negotiation format, was assisted by a legal service that included the legal advisers of both

9. For a discussion of the role of the Council Secretariat in the process of EU treaty reform, see T.Christiansen, 'The Role of Supranational Institutions in EU Treaty Reform', Journal of European Public Policy, Vol.9, No.1 (2001), pp.33-53. 
Commission and Council Secretariat. By the time of the next IGC, the Council Secretariat was made solely responsible for legal advice, and this has remained the practice ever since.

The capacity of the Council Secretariat to intervene in the negotiations - if requested - through the provision of legal advice stands alongside the more general, and substantive, advice the Council Secretariat staff can, and does, provide in the negotiations. Such an ability to provide advice, and the willingness of the Presidency and the other delegations to accept it, is derived from two aspects of the Secretariat's involvement in IGCs. First, the Council Secretariat acts as the institutional memory of the conference. As the official record-keeper of the conference, the Secretariat has easy access to past discussions, documents and papers, and can use these, as appropriate, in order to influence ongoing negotiations.

A second, related, point concerns the personal experience of the Secretariat staff involved in the IGC negotiations. In contrast to the situation in member states, where political change and administrative turnover in foreign offices tend to change the composition of national delegations, the staff in the Council Secretariat unit responsible - the 'Directorate for General Political Questions' - has experienced greater continuity and therefore possesses greater personal knowledge of the past IGC record. Possessing both the institutional record of, and the personal insights into, these intricate and complex matters provides Council Secretariat staff with a valuable resource in the negotiations.

However, statements about the potential influence of the Council Secretariat have to be qualified on a number of counts. First, the opportunities arising for the Secretariat staff to influence the negotiations lie predominantly in finetuning the detail of treaty revisions, not in the decisions 
about the broad outlines of treaty reform. That is one reason why the involvement of the Council Secretariat has hardly reached the public limelight. Nevertheless, such influence in legal detail may have significant political impact and deserves to be addressed systematically in research on treaty reform.

A second, more important qualification concerns the Secretariat's relationship with the Presidency which, as already noted in the previous section, is a flexible one. Much of what has been said above regarding the significance of the Council Secretariat's role in drafting agendas and meetings, providing legal and other advice and fine-tuning the detail of negotiations crucially depends on the permissiveness of the Presidency to provide such opportunities for influence. That is why, ultimately, we can only speak of potential influence of the Secretariat. Formally, the Secretariat is charged with assisting the Presidency, and its influence is realised if and when a Presidency does indeed rely on the assistance which the Secretariat can offer.

In the past, this is what Presidencies have usually done, though there are also noteworthy exceptions. Until the French Presidency in the second half of 2000, any period of IGC negotiations had been presided over by one of the smaller states, and these generally welcome the assistance which the Council Secretariat can provide, given the pressure on a country's resources during the Presidency. On that basis, the detail of IGC negotiations have usually been managed in 'Brussels', i.e. in close co-operation between the Permanent Representation of the member state holding the Presidency and the staff of the Council Secretariat. This cooperation routinely stretches to the first draft of the minutes of meetings, the conclusions of ministerial and European Council meetings or even draft treaties being written in the Council Secretariat. Given the significance which is usually 
attached the role of the Presidency in steering the IGC, this 'behind the scenes' influence of the Council Secretariat is remarkable.

With the adoption of a convention method to prepare the 2004 IGC, it might be asked what such additions to the treaty reform process hold in store for the Council Secretariat. One might assume that a greater degree of openness would diminish the role of the Secretariat, and therefore also its potential for influence. However, the experience of the Fundamental Rights Charter Convention seems to suggest otherwise. Here, again, the Council Secretariat, providing the Convention's secretariat and legal service turned out to be an influential player in the proceedings. Indeed, one could argue that because of the higher number of participants, the greater choice of options, and the absence of the Presidency as pivotal player, a future convention may require more, rather than less, input and 'assistance' from the Council Secretariat.

With respect to the Convention preparing the 2004 IGC, the waters are further muddied by the fact that the Convention Secretariat is staffed not only by the Council Secretariat, but also by the European Commission and the European Parliament. The Laeken Presidency Conclusions state that the Convention "Praesidium will be assisted by a Convention Secretariat, to be provided by the General Secretariat of the Council, which may incorporate Commission and European Parliament experts." It will be interesting to observe the co-operation between the three institutions in the running of the convention. So far, the drafting I which the Secretariat has assisted, in particular the work on the Convention's budget and the draft constitutional treaty published in October 2002, - and the media reaction to it - has demonstrated that it is more than merely a technical task. 
The introduction of a convention is widely seen as a response to the inefficiencies of the IGC method. Already it is obvious that the convention method is rich in institutional innovations: for example, it is the first time that national MPs and representatives of non-member states participate directly in the revision of the treaty. Building on the experience, and the precedent, of the Fundamental Rights Convention, it does promise a new departure in the institutionalisation of the treaty reform process. At the same time, its influence over the subsequent IGC proper will be resisted by Member States. In this context, many of the institutional choices to be made by the Convention Praesidium may turn out to have a much wider, long-lasting and ultimately constitutional significance. The Council Secretariat, in advising and assisting the Praesidium ${ }^{10}$, will closely involved in the making of these choices, placing it at the heart of the EU's constitutional politics of the next few years.

10. The website of the Convention states that the "Convention and the Praesidium are supported by a Secretariat, which is headed by its Secretary-General, Sir John Kerr, former head of the British Diplomatic Service. The Secretariat provides assistance to all members of the Convention on all aspects of the Convention's work, in particular by preparing discussion documents for the Convention, drafting reflection papers, and drawing up syntheses of the debates. It also assists the Chairman, the two Vice-Chairmen, and the "Praesidium". In addition, the Secretariat is responsible for the logistic and practical arrangements of the Convention, and is entrusted with organising the activities of the Forum. Its members are drawn primarily from the General Secretariat of the Council, but include also experts from the European Commission and European Parliament Secretariat, as well as members seconded from outside the institutions." See http://european-convention.eu.int/ 


\section{Out of the Shadows: The Council Secretariat and EU Foreign and Security Policy}

With respect to the first pillar policy-process and the treaty reform process, the Council Secretariat's responsibilities and opportunities for influence are rather similar, despite the fundamentally different context within which its work takes place. With respect to the second pillar of EU policymaking, however, the Council Secretariat is an entirely different animal. While it is true that in CFSP matters the staff of the Council Secretariat is formally still 'advising' and 'assisting' the Presidency, and that much of the work also here concerns the running of committees (in particular the Political Committee and its sub-committees), in practice the Council Secretariat has developed into a quasi-executive agency making policy in its own right.

The acquisition of these powers has been gradual, but the speed of these changes accelerated in the course of the 1990s. Member States, concerned to achieve greater coherence in their efforts to co-operate in foreign policy matters, sought to improve the institutional underpinnings of foreign policy-making. At the same time, they were loath to give the Commission additional powers in this field, an option theoretically open to them, and one that is still being advocated by the Commission itself.

Member States squared the circle by building up foreign policy structures in the Council Secretariat rather than relying on those (e.g. the External Relations DG) already present in the Commission. The EPC secretariat, created in 1986 outside the Community structure, was incorporated into the Council Secretariat after the Maastricht Treaty. This followed the acknowledgement that foreign policy was a responsibility of the Union, and that Union institutions needed to be involved in it. The treaty states that the Commission is 'fully associated' with CFSP, but the 
centre of gravity in this respect is clearly in the Council of Ministers.

Once this basic decision was taken, institutional growth quickly set, fuelled by the wars in Bosnia and Kosovo which implied further pressure on the EU to create the institutional capability to address foreign crises swiftly and concertedly. At the end of the 1990s, this institutional architecture was indeed transformed, with Javier Solana serving as a decidedly pro-active and high-profile High Representative, supported by a Policy Unit (initially designated as an 'Early Warning and Policy Planning Unit'). The Council has also appointed a number of special envoys to represent the $\mathrm{EU}$ in crisis areas such as Afghanistan, the Middle East and the African Great Lakes region.

The most recent and far-reaching development has been the creation of military structures in the Council Secretariat. As part of establishing a distinct EU defence capability, the Council Secretariat has taken over significant parts of the WEU secretariat (with Javier Solana also acting as WEU Secretary-General), the creation of a new committee structure (Political and Security Committee, Military Committee) and the establishment of the EU's own Military Staff. The latter is headed by a German general, deputised by a British general, acting as the Director-General of the EU Military Staff, attached to the private office of Javier Solana. In this case, as with most of the appointments in the new posts in the area of CFSP and Military Staff have been filled with officials seconded from national foreign and defence ministries. This increase in the incidence of secondment adds a further dimension to the impact these developments have had on the Council Secretariat ${ }^{11}$.

11. See J.Trondal, The 'Parallel Administration' of the European Commission National Officials in European Clothes?, ARENA Working Papers WP 01/25 (Oslo: ARENA, 2001) for a discussion of secondment in the EU. 
Foreign and defence policy may not primarily be about legislation. In most cases, diplomacy aims to regulate behaviour through declaratory acts rather than through law. In fact, the most frequently-used instruments in CFSP are 'CFSP statements' which are usually issued by the Presidency on behalf of the Council. There are about 200 such statements annually, and clearly the almost daily issuing of such statements requires co-ordination across national positions as well as an awareness of the EU's case history with respect to particular countries or issues which are the object of CFSP statements. The need for 'advice' from the CFSP case officers in the Council Secretariat does have an important role to play, in particular given the significance of the actual wording of statements in a diplomatic context.

Diplomatic statements or declarations are issued not just from the Presidency, but also from the CFSP machinery directly. Above all, the speeches, statements and interventions made by Javier Solana himself are part of the overall diplomatic output of the European Union, and their impact in third countries may be the same, if not greater, than the formal Presidency statements. And beyond formal statements, the HR and his CFSP staff make policy in their dealings with third countries, interpreting and implementing common positions agreed upon by the Member States.

However, while the Council Secretariat may be quite close to the process of drafting and issuing statements and decisions, it often finds itself rather distant from the 'ground', i.e. the third countries which may be the object of the Union's attention. In this respect, the absence of direct access to diplomatic missions is a short-coming which is keenly felt in the Council Secretariat. The fact that Member 
States as well as the Commission have delegations in most countries provides them with privileged access to information required for effective action, and in this respect the Council Secretariat relies on assistance and co-operation - not always forthcoming - from these other actors.

There is a legislative angle to the CFSP. In fact, there is a long list of 'legislative acts' in the area of CFSP, including decisions such as those on the appointments of special EU representatives, the sending of monitoring missions, the imposition of economic or other sanctions, and the like. The CFSP has produced hundreds such acts since 1993, a trend facilitated by the possibility of using qualified majority vote under the umbrella of previously agreed 'common strategies' of which there are currently three (relations with Russia, Ukraine and the Mediterranean, respectively).

It may be worth recalling at this stage that the earlier assessment of the Council Secretariat's main influence in policy-making in the first pillar and in treaty reform was reactive - it could only bring its influence to bear on decisions which other actors (in particular the Commission) had brought onto the agenda. With respect to the second pillar, that feature is also very different, in that proposals or recommendations for policy may come from a number of actors, including from the High Representative himself - a feature of the institutional structure of which Javier Solana has made frequent use.

Much of the history of foreign policy co-ordination in the EU has been about the search for a distinct 'actorness' of the EU in the international sphere. Having largely achieved this aim in the trade sphere, it is still lacking a similar, distinct identity in the foreign and security field. But significant advances have been made in this respect over the past decade, and the institutional resources available for common EU action in the foreign policy are now much more 
favourable towards this long-standing goal of European integration. If a perception of 'actorness' is still lacking, in particular with respect to major global crises (vide the image of disunity with regard to the stabilisation force for Afghanistan resulting from the Laeken summit) it is due to the lack of substantive agreement among national governments and the absence of political will to achieve such agreement rather than the lack of institutional resources. What is evident from the status quo of the decision-making in the CFSP field is that a perception of EU actorness, if and when it does emerge, will centre around the work of the High Representative, the Policy Unit and other parts of the Council Secretariat.

The Council Secretariat's activity in the CFSP area is further complicated by two particular issues. First, there is the need - indeed the demand of the treaty - to maintain coherence between the different pillars of EU policymaking. This a challenge as the achievement of such coherence requires not only the management of linkages between first pillar matters (in particular trade, development and competition policies) and second pillar matters in the foreign policy and security field, but also the close coordination of activities between the European Commission and the Council Secretariat, given their shared responsibilities in the second pillar ${ }^{12}$.

A second, but related, problem concerns the issue of transparency, or, as many would argue, the lack of it. The Council of Ministers is, together with the other EU institutions, formally committed to an agenda about the

12. See C.Tietje, 'The Concept of Coherence in the Treaty on European Union and the Common Foreign and Security Policy', European Foreign Affairs Review, Vol.2, No.2 (1997) pp.211-233, for a discussion of the implications of coherence in the making of CSFP. 
achievement of greater transparency ${ }^{13}$. However, the Council has been repeatedly criticised - by the European Parliament and the European Ombudsman as well as by other bodies about its tardiness in implementing more ambitious rules of procedure which would facilitate greater transparency ${ }^{14}$. However, just as there are calls for greater transparency, there is also the need for greater secrecy as the Council Secretariat - its staff and its offices - accumulates increasingly sensitive tasks in the security and defence field. The Council Secretariat's lack of procedures, facilities and resources has led to problems in the past ${ }^{15}$ - a situation that has driven Javier Solana to actively pursue the development of an internal security reform of the Secretariat. This involves both the relocation of staff occupied with sensitive tasks to a new, secure building outside the main Justus Lipsius Building as well as the creation of a classification regime for secret EU documents ${ }^{16}$. This so-called 'Solana Decision' brought the Council of Ministers in line with the current practice in NATO, but it does fly in the face of the wider transparency agenda. As such, it proved to be a highly controversial measure, leading to protests form civil rights groups as well as to legal disputed with the European Parliament and with the minority of Member States which

13. See General Secretariat of the Council of the EU Basic Texts on Transparency concerning the activities of the Council of the EU (Brussels: 2000).

14. See, for example, European Voice (2001f) 'MEP's set for Court fight over 'illegal' Council security rules', 5 July 2001; and European Voice (1996) 'Secrecy report - sorry, it's secret', 3 October 1996.

15. See, for example, The Guardian 'Security lapses in Brussels HQ cast doubt on EU defence plans', 19 February 2000.

16. Council of the European Union Decision of the SecretaryGeneral of the Council/High Representative for the CFSP on measures for the protection of information applicable to the General Secretariat of the Council (2000/C 239/01) (Brussels). 
opposed this measure ${ }^{17}$. The conflicting demands of transparency and secrecy - and the wider aims of achieving greater legitimacy in the eyes of the European citizens on the one hand, and greater credibility in the eyes of the defence community in Europe and in the US - are an important and continuing strain on the institutional integrity of the Council Secretariat.

The Union's rapidly expanding agenda in the area of Justice and Home Affairs (JHA) has also presented the Council Secretariat with new challenges. In addition to problems similar to the second pillar - incorporating new staff and administrative cultures, developing and expertise in new policy-areas - there has also been a particular challenge: the provision in the Amsterdam Treaty giving Member State governments the right to initiate legislative proposals. Governments seeking to make use of this power quickly discovered the need to involve a central authority in the drafting of such proposals, given their lack of experience in this field. Thus also in this respect the Council Secretariat has had to develop new skills in terms of co-ordinating different member state positions and assisting individual governments to advance their legislative projects. This in turn has required co-operation with the Commission's DG for JHA, especially since the Commission is gradually taking over sole responsibility for proposing legislation in this field.

17. See the contributions to the Statewatch 'Secret Europe' website on http://www.statewatch.org/secreteurope.html 


\section{Conclusion}

The preceding sections have demonstrated the degree to which the Council Secretariat has been at the heart of some of the key developments in the past decade. The Secretariat is playing an increasingly important role in the mediation of different member state positions in the Council, and in the running of the wider, inter-institutional process in the EU's legislative process. In doing so, it relies on important resources to which other actors only limited access: legal expertise in the highly complex and technical area of EU legislation; the bureaucratic memory of past decisions and proposals, which may provide precedents for or against new legislative or administrative initiatives; the membership of its staff in the Brussels-centred informal policy-networks; and the privileged access Secretariat staff possesses vis-à-vis the Presidency.

These factors are complemented by some of the structural features of EU governance in which the work of the Council Secretariat is embedded. These include the permanency of its presence in the many fora of deliberation and decision-making within the Council structure, especially against the background of a rotating Presidency presenting the Council Secretariat staff with new and often inexperienced 'customers' every semester. Another is the privileged position it enjoys in terms of providing deliberation ministers or national officials with legal advice.

After decades of institutional stasis, some of these arrangements have come under closer scrutiny, and some have actually been changed. For example, the decision at the Nice European Council to discontinue the past practice of staging European Council meetings in the country holding the Presidency and instead have European Council meetings at a permanent location in Brussels. It was one of the lastminute decisions at Nice (and one of which apparently not 
even all heads of state present were aware) and has widely been interpreted as a trade-off to appease Belgium for its loss voting power parity vis-à-vis the Netherlands. This development is, however, also in the interest of the Council Secretariat as it provides further impetus to a shift of decision-making from national capitals to the centre. The impact of a departure from the practice of the rotating Presidency, as it is now being discussed among member states, is uncertain.

As we have seen, the Presidency has provided the Council Secretariat with an important opportunity structure, creating a constant sequence of national ministers and officials who are dependent on the advice from, and guidance by, the Council Secretariat. However, there are now suggestions that the format of the Presidency will have to change and that the operation of the Council be streamlined $^{18}$. It is difficult to see how the Presidency, which has occupied such a central place in the history of the EU, could be replaced. If the powers of setting the Council's agenda and chairing its meetings were to be handed over to the Secretary-General, this would constitute a further boost to his (or hers), and the institution's, importance in the EU's legislative process. However, other solutions which would rely on more systematic presence of member state representatives - such a permanent Council of European ministers - would have the opposite effect. The same is true for some of the ideas which are currently being discussed in the context of the Future of Europe debate: the further reduction in the number of sectoral councils, greater transparency in ministerial councils and the 'democratisation' of the treaty reform process. All of these

18. See for example European Voice (2002) 'Closing time may be near for the presidency merry-go-round', 24 January 2002 and Financial Times 'Blair and Schröder join forces on EU reform', 24 February 2002. 
threaten the privileged position the Council Secretariat has occupied in the past.

The debates on a European Constitution which have been conducted within the Convention have special relevance here for the future development of the Council Secretariat. the old schism between intergovernmental and supranational solutions to the dilemmas posed by European integration are increasingly expressed in terms of greater powers to either the Commission or the Council Secretariat, with the latter appearing to gain the upper hand. Increasingly, there seems to be consensus among most Convention members that the Council Secretariat rather than the Commission needs to be strengthened and can constitute a more reliable actor at the European level. In the process, 'intergovernmentalism' is being re-defined: rather than denoting the interaction among governments, it is increasingly understood as executive responsibility residing with the Council Secretariat.

The twist in this context is the evolving discourse about the creation of a President of the European Council, which would replace the rotating Presidency and give greater visibility to the Union, externally and internally. Presumably this would be political appointment at the highest level - a Javier Solana Plus - and would imply a term of office of $21 / 2-5$ years. This is an idea pushed, in particular, by the French and British governments while it is widely seen as an attack on the standing of the Commission President, and thus is opposed by the smaller member states and the Commission itself.

While the outcome of this debate is not at all conclusive, the impact of such changes on the Council Secretariat is an interesting question. At first sight the creation of such a new post would seem to imply a further strengthening of the Council Secretariat's grip on power. 
However, at second sight one can see how such institutional innovations may work against the influence of the Council. Earlier the point was made that the actual input of the Secretariat relied to a large extent on the need of the Presidency for advice, which in term was the result of the short term and frequent change in the Presidency.

The creation of more permanent structures - the European Council President and the appointment of individual presidents also for the sectoral councils - would thus limit the influence that officials in the Council Secretariat would have over the legislative process. In the end, the question would be whether those holding a Council Presidency of longer duration would become part of the Council machinery or remain essentially senior politicians drawn from - and essentially remaining within - national political cultures and hierarchies. For the time being, this is an open question, but one whose resolution clearly will have a major impact on the way the Council Secretariat operates and relates to other institutions.

But short of such drastic changes, the EU is already in the midst of important reforms occurring at a number of levels: the debate about the nature of European governance in the wake of the Commission's White Paper on the subject, the reform of the Council's working methods which had been prepared by Javier Solana for the Seville European Council $^{19}$ and the wider agenda of the Convention preparing the IGC 2004. Each of these is bound to have a major impact on the role of the Council Secretariat. This statement, in itself, is testimony to the heightened role the Secretariat has gained in the course of European integration during the

19. This review of the Council operating procedures is based on the earlier Trumpf-Piris report: Secretary-General of the Council of the EU (1999) Operation of the Council with an Enlarged Union in Prospect (Brussels: 1999). 
1990s and early 2000s. But rather than being merely the object of reform, the Council Secretariat is a subject in the ongoing reform negotiations. The Council of Secretariat has moved out of the shadows to become a recognized player in the EU's legislative and treaty reform processes. 


\section{Chapter 6}

\section{Intra-institutional politics and inter-institutional relations in the $\mathbf{E U}$}

As part of the 'post-Nice process', a variety of issues relating to the institutional and constitutional evolution of the European Union now receive greater attention. One of these is the question of coherence in European governance. 'Coherent governance', however, is not a very well-defined concept, and different interpretations are possible. Briefly mapping the field, a number of distinctions may be offered here: first, we can conceive of 'coherence' in terms of the systemic outputs, i.e. the way in which the substance of different policies generated by the EU form part of a coherent whole. Alternatively, we can regard 'coherence' in terms of the institutional process by which policies are made, i.e. in terms of the degree to which institution(s) operate a coherent and well-co-ordinated process of deliberation and decision-making. This article focuses on the latter which in the following is termed 'institutional coherence'. 
A further distinction can be made in terms of the pursuit of inter-level, inter-institutional and intrainstitutional coherence. In other words, the issue of coherence can be examined along these three dimensions: first, at the inter-institutional level, in particular in terms of the coherence (or lack of coherence) of Commission and Council Secretariat activities. Second, in terms of the relations between actors on different levels, in particular with regard to the congruity (or otherwise) of national policies and of EU policies. Finally, a further issue of coherence arises in terms of the internal, or intrainstitutional, coherence of either of these institutions, given the possibility for internal fragmentation (see figure 1 below):

\begin{tabular}{|l|l|}
\hline Dimension & Focus \\
\hline Inter-level coherence & $\begin{array}{l}\text { Relations between EU-level } \\
\text { institutions and national authorities }\end{array}$ \\
\hline $\begin{array}{l}\text { Inter-institutional } \\
\text { coherence }\end{array}$ & Relations among EU institutions \\
\hline $\begin{array}{l}\text { Intra-institutional } \\
\text { coherence }\end{array}$ & Internal politics of EU institutions \\
\hline
\end{tabular}

Figure 1 Dimensions of 'institutional coherence' in European governance

This article concentrates on the operation of the European Commission and the General Secretariat of the Council of Ministers $^{20}$ along two of the dimensions mentioned above -

20 The Secretariat of the Council of Ministers is not formally recognised as an 'institution' of the EU in the Treaty. Instead, it is categorised as an organ of the Council, which is the actual institution. Nevertheless, the Secretariat is here regarded as an institution for the purposes of analysis since it does possess the required criteria. 
the relations between the two institutions as well as the issue of the internal politics of the EU institutions.

In recent years, the EU has faced contradictory demands concerning its inter-institutional relations. On the one hand, there is concern about the 'coherence' or 'consistency' of policy-making across the various levels and pillars of European governance. On the other hand, there are demands for greater clarity about the allocation of competence and the separation of powers in the European Union. Given the frequency of treaty reform since the early 1990s - since when the EU has been involved in either the preparation, negotiation or ratification of a treaty change at any one point - the tensions between these conflicting demands has gradually increased. In the course of the current debate about the 'Future of Europe', meant to prepare the ground for the next Intergovernmental Conference (IGC) in 2004, the arguments for interinstitutional coherence, on the one hand, and the allocation of tasks in line with the principle of separation of powers are meeting head-on.

The issue of coherence has become particularly pertinent as the Secretariat of the Council of Ministers has acquired substantial executive functions in the area of EU foreign and security policy (CFSP) and, to a lesser extent, in the area of police and justice affairs. The emergence of an executive role of the Council Secretariat means that the potential for fragmentation across EU institutions has increased, given the European Commission's responsibilities for managing the Union's external relations and aspects of internal security (Smith, 1994). In addition, there is increasing demand for greater co-operation between, and co-ordination of, the foreign policies of the member states and the management of the EU's external relations by Commission and Council Secretariat. 
On the other side, among those looking for a clearer separation of powers (rather than institutional coherence), a similar, two-dimensional distinction is possible (as indicated in the figure below): on the one hand, there is the issue of the allocation of competences between the national and the European level - the question of Kompetenzabgrenzung between member states and the EU which, mainly due to German demands, constitutes one of the items on the agenda of the 2004 IGC (and therefore of the Future of Europe debate leading up to it). On the other hand, there is the issue of allocating tasks more clearly to the European institutions, in particular to the Commission and the Council Secretariat. Should this allocation of tasks be governed by the constitutional principle of the separation of powers, as demanded by some (Sozialdemokratische Partei Deutschlands, 2001; see also Leanarts, 1991), then the Commission would move further into the role of the EU executive - even turning into the 'European government' as envisaged by its supporters (Prodi, 2001). The Council of Ministers and its Secretariat, on the other hand, would share the legislative function with the European Parliament becoming more explicitly the EU legislature's 'second chamber - while ceasing to chare the executive function with the Commission, as is the case now. 


\begin{tabular}{|l|l|l|}
\hline & $\begin{array}{l}\text { Coherence of } \\
\text { European } \\
\text { governance }\end{array}$ & $\begin{array}{l}\text { Separation of powers in } \\
\text { European governance }\end{array}$ \\
\hline $\begin{array}{l}\text { Inter-level } \\
\text { relations }\end{array}$ & $\begin{array}{l}\text { Close co-operation } \\
\text { between national } \\
\text { authorities and EU } \\
\text { institutions }\end{array}$ & $\begin{array}{l}\text { Clear delineation } \\
\text { between the competences } \\
\text { of the national and the } \\
\text { EU level }\end{array}$ \\
\hline $\begin{array}{l}\text { Inter- } \\
\text { institutional } \\
\text { relations }\end{array}$ & $\begin{array}{l}\text { Close co-operation } \\
\text { between Commission } \\
\text { and Council Secretariat }\end{array}$ & $\begin{array}{l}\text { Clear delineation of tasks } \\
\text { between Commission and } \\
\text { Council Secretariat }\end{array}$ \\
\hline
\end{tabular}

Figure 2 'Coherence' and 'Separation of Powers' in the EU's constitutional debate

In the following, we will therefore first examine the recent evolution in the internal politics of two of the EU's main institutions, identifying instances of internal fragmentation and institutional coherence in the European Commission and the Council Secretariat. Subsequently, the focus will shift to the management of inter-institutional relations, with particular emphasis on the relations between Commission and Council Secretariat across a number of areas with shared responsibilities. Such a partial study of the incidence of coherence (or otherwise) in European governance, looking in turn at the internal politics and the inter-institutional relations of the EU institutions, does not constitute a comprehensive analysis of coherence in the Euro-polity. However, it does provide the basis for some tentative explanations concerning the presence or absence of coherence of European governance, which are discussed in the concluding section. 


\section{Internal politics of the $\mathrm{EU}$ institutions: Towards intra-institutional coherence?}

Commission, Council or Parliament are frequently regarded unitary actors. However, all three institutions - and indeed other important EU institutions such as the European Court of Justice or the European Central Bank - often face numerous internal divisions. Depending on their seriousness, such divisions may translate into fragmented policy-making and thus undermine the coherence of EU governance.

In examining the internal fragmentation of EU institutions, one may distinguish between generic issues applying to all EU institutions and those which are specific to individual institutions. Looking first at the more generic issues, two particular challenges to intra-institutional coherence can be identified.

First, all EU institutions have over the past decade been faced with substantial growth, and - in terms of achieving institutional coherence - size matters. More significantly, institutional growth has been rapid and diverse. On the one hand, the last enlargement has brought in three new member states, with the resultant expansion of staff numbers, budgetary revenues and disbursements and area coverage of EU policies. It has also brought in two additional official languages, implying an exponential rise in the number of language pairs for translation. Growth has also been a result of the expansion of competences acquired by the EU, resulting in the need for expertise in entirely new areas of activity such as military co-operation or justice and home affairs.

Second, partially as a result of these trends of institutional growth and policy-expansion, the specialisation of individual policy-makers has increased. The relevance of 
policy-networks and policy-communities in the EU is widely recognised. Policy-networks, -communities and coalitions imply close links and even shared values among policy-makers from different institutional backgrounds with a common concern for a specific policy. From an institutional point of view, he presence of effective policynetworks may, on occasion, advance a particular institution's aims, but in the long run is bound to be detrimental to institutional coherence. As policy-making becomes more specialised - as it has in the EU during the 1990s, a growing number of such networks makes it more difficult for individual institutions to manage internal coordination and achieve coherence.

\section{Internal tension in the European Commission}

The problem of tensions within the European Commission is not a recent phenomena. Indeed, the very nature of the Commission - a single institution encompassing large and relatively self-contained Directorate-Generals (DGs) - is a recipe for fragmentation and internal tension. Due to the internal divisions running through it, authors have for some time regarded it as a 'multi-organisation' in which the policy-making of different administrative units creates different bureaucratic and organisational logics (Cram, 1994).

Beyond these sectoral or 'horizontal' divisions within the Commission, there has also been a 'vertical' divide between the Commission's political level - the college of Commissioners - and the administrative services (Christiansen, 1997). Organisational logics are distinct with respect to either of these levels. The college of Commissioners operates on the basis of non-hierarchical principles: despite the presence of President and two Vice- 
Presidents, Commissioners have equal votes in the college, Commission decisions are, if necessary, voted upon, and require a simple majority of Commissioners. Once the college has taken a decision, all members of the Commission are bound by it, and are expected to support a common position, irrespective of their individual vote. The Commission President, notwithstanding recent changes to his (or her) position (see below), is a primus inter pares who is also bound by these rules. The Commission's administrative services in the DGs, on the other hand, are organised in a hierarchical manner, along the lines of public administration in domestic systems.

Against this background, the Commission arguably more than any other EU institution - has had to face the consequences of the above-mentioned trends of institutional growth, policy-expansion and policycomplexity in the European Union. Growing size of, and greater specialisation within, the Commission have amplified the internal divisions, and both the fall of the Santer Commission and the first years of the Prodi Commission have demonstrated the weakness of internal cohesion.

The crisis preceding the forced resignation of the Santer Commission arose from allegations of mismanagement and fraud which were investigated by a Committee of Independent Experts appointed by the European Parliament. In its first report, the Committee identified the lack of communication between the Commission's political and administrative levels as a key problem:

9.3.4. The Committee found that the relationship between Commissioners and directors-general did not always meet this standard. The separation between the political responsibility of 
Commissioners (for policy decisions) and the administrative responsibility of the director-general and the services (for the implementation of policy) should not be stretched too far. As stated above, it is the opinion of the Committee that Commissioners must continuously seek to be informed about the acts and omissions of the directorates-general for which they bear responsibility and that directors-general must keep their Commissioners informed of all major decisions they take or become aware of. This requirement of mutual information implies that Commissioners must be held to know what is going on in their services, at least at the level of the Director-General, and should bear responsibility for it. (Committee of Independent Experts, 1999).

Apparently, the collective responsibility of the college of Commissioners did not translate into the individual responsibility of Commissioners for the administrative services within their respective portfolios. Indeed, in a number of cases, Commissioners in the Santer Commission shared responsibility for a particular DG. Such structural flaws, together with the failings of individual Commissioners to exercise proper oversight over 'their' services, contributed to a state of affairs which the Committee described as “... a growing reluctance among the members of the hierarchy to acknowledge their responsibility. It is becoming difficult to find anyone who has even the slightest sense of responsibility." (Committee of Independent Experts, 1999, para 9.4.25).

This diagnosis is testimony to the fundamental problems the Commission has had in seeking to achieve internal coherence, not only with regard to the horizontal 
co-ordination of its policies, but also, and in particular, in terms of the vertical relationship between political and administrative spheres within the Commission. It also implied that the cabinets, who in addition to advising Commissioners have played a central role in co-ordinating policies horizontally and managing communications between Commissioners and their respective DGs (Donnelly and Ritchie, 1994), were overburdened with these tasks.

Against the background of the Committee's criticisms, a number of reforms of the Commission since the appointment of Romano Prodi have sought to remedy these problems. In particular, three aspects of Commission reform can be examined in terms of their impact on institutional coherence: certain organisational changes made by President Prodi soon after his appointment, the ongoing reforms supervised by Reform Commissioner Neil Kinnock, and the changes to the office of the President resulting from the Nice Treaty.

First, one of Prodi's responses to the 'vertical divide' between the political and the administrative level of the Commission was a seemingly simple one: Commissioners had to 'move in' with their services. Under Santer (as under Delors) Commissioners shared a single building, together with their cabinets and with key parts of the Secretariat-General. This arrangement facilitated the exchange between the various cabinets in the co-ordination of policies generally, and in preparation of the weekly meetings of the college, the chefs de cabinet and the deputy chefs.

However, the flipside of this coin was the physical distance between Commissioners and cabinets on the one hand, and the DGs on the other. Commissioners residing collectively in the Berlaymont, and later the Breydel, while 
services have been scattered across a multitude of different locations across Brussels, added - practically as well as symbolically - to the perceived distance between political and administrative spheres of the Commission. The move of Commissioners from the Breydel headquarters to the separate buildings of their respective DGs - which required first a streamlining of services to ensure that each Commissioner actually has $a \mathrm{DG}$ - has demonstrated the dilemma faced by an institution that has to manage tension along two dimensions: just as communication between Commissioners and services may have become easier (though, for reasons discussed below, it may not), communication among Commissioners and, crucially, among cabinets has become significantly more difficult. Previously, meetings and informal conversations among members of different cabinets were a common part of the daily work routine as they could easily be arranged along the same corridor. Now, given that offices may be at the other end of town, meetings need to be organised in advance, and informal conversations have all but ceased. Consequently, horizontal co-ordination - not only crucial in terms of the coherence of the Commission's policy-output, but also essential for ensuring the functioning of collegiate responsibility - has become more difficult and timeconsuming. As it happens, the relocation of Commissioners coincided with another Prodi reform: the reduction of cabinet staff to a maximum of six per Commissioner. Together, these changes add substantially to the workload of cabinets and limit the time and care spent on policy-coordination. In other words, what has been gained in terms of coherence on one side ('vertically') has been paid for on the other side ( 'horizontally').

A second response to deal with the underlying problems leading to the crisis of the Santer Commission has been the launch of a broader, more long-term set of internal 
reforms overseen by Vice-President Kinnock. This reform programme is underpinned by an administrative structure comprising the new office of a Reform Commission, a 'Group of Reform Commissioners' and a Reform Task Force. Its aims are, broadly speaking, to make the Commission more accountable, effective and cost-efficient (Metcalfe, 2000). The emphasis here is on matching staff resources with policy-priorities, revising financial regulations in order to make decisions about payments more accountable and transparent (Spence, 2000). In the course of the process, administrative reform in the Commission has become a major 'policy' in itself, and for the duration of the 'transition period' - the time it takes to agree the details of these reforms, to re-locate staff and change internal procedures - it has a distinctly de-stabilising effect on Commission staff.

The Kinnock reforms aim squarely at the issue of 'responsibility' (Cini, 2001) identified as a major failing by the independent experts. However, the reforms do not properly address the problem of the vertical divide between Commissioners and DGs. The reform programme addresses essentially the functioning of the administrative services rather the relationship between college and administrative service, or the functioning of the college itself. The reforms therefore do not address key issues which contributed to the downfall of the Santer Commission. Indeed, to some of the staff in the administrative services they are regarded as an exercise in 'scape-goating' - identifying the administration rather than the Commissioners as a liability for responsible and accountable public service in Europe.

The Commissions staff unions have been critical of the Kinnock proposals, and the threat of a strike among Commission officials in the spring of 2001 could only be averted through a renegotiation of the reform package. 
Generally, relations between Commissioners and senior officials have, if not worsened, certainly not improved, with frequent reports of friction between Commissioners or Commission President, on one side, and Director-Generals, on the other (European Voice, 2001a; 2001b; 2003c).

The preliminary observation at this point is therefore that over the past few years the internal tensions in the Commission have increased, both with regard to vertical and to horizontal relations. Consequently, we have to conclude that the foundations for the achievement of enhanced internal coherence have worsened in the aftermath of the Santer Crisis. At the very least, the reforms launched by Prodi and Kinnock have not substantially improved the opportunities for more coherent internal management of the Commission. Part of the problem here is that, as yet, no final point for these reforms can be identified - which is why it is impossible to make judgements about the ultimate effects (and 'success') of these reforms. However, this state of affairs in itself - the nature of limited internal reform turning into a seemingly permanent programme of reform (and turmoil and uncertainty) - is destabilising for staff morale and detracting from internal coherence.

There has been, however, a third level of reform which deserves a few comments. At the level of treaty change, Commission reform had been on the agenda at Amsterdam and again at Nice. At Nice, a number of changes to the operation of the Commission were agreed. The more important ones here concern the role of the President whose hands are to be strengthened vis-à-vis the individual Commissioners: in what was essentially a recognition of the state of affairs which Prodi and the European Parliament had already established de facto at the time of the current Commission's investiture, according to 
the new Art. 217 the President will be able to request that a Commissioner shall resign. He (or she) will also have the explicit power to decide on the internal organisation of the Commission and to allocate the responsibilities of the Commissioners, both at the time of appointment and throughout the term of the Commission.

This is not a departure from the principle of collegiality - indeed the college has to approve the President's request for the resignation of Commissioners (Art.217 (4)) - but it should strengthen the President's hand vis-à-vis individual Commissioners and in principle allows him to run the Commission with greater authority. The anticipated effect of these changes is a Commission in which individual Commissioners take greater responsibility for their respective portfolios and, should they fail to perform, can be sanctioned by the President. Thus it can be seen as a further attempt to improve the accountability of Commissioners and their responsibility in overseeing their services. However, at the time of writing the Nice Treaty is not yet ratified - indeed it has been rejected in the Irish Referendum in June 2001 - and even if and when it is, it may take time for these treaty changes to translate into actual authority for the President. For the time being, the difference in the leadership qualities of Delors, on the one hand, and of both Santer and Prodi, on the other, serves as a stark reminder that the formal rules are only part of the story, and that the authority of the office of President also depends on the individual occupying it (Drake, 1995; Peterson, 1999; 2000).

\section{Internal tension in the Council Secretariat}

The creation of the pillar structure at Maastricht, removing the Commission's monopoly of initiative in important new 
areas of EU competence empowered the Council Secretariat. Before and after Maastricht, a determined campaign by some member states as well as by the Council Secretariat has been to keep the institutionalisation of the policy out of the hands of the Commission. It has been a campaign that has had demonstrable success in that initially the EPC Secretariat was created outside the existing institutional structure rather than being added to the portfolio to the Commission. At Maastricht, this Secretariat was then merged with the Council Secretariat and at Amsterdam the new post of High Representative was created as an adjunct to the responsibilities of the Council Secretariat Secretary-General. Beyond the appointment of Javier Solana to this new post, an expansion of staff at the Council Secretariat was the result of these changes. A number of EU Special Envoys to certain crisis-regions across the globe are also based at the Council Secretariat. In a nutshell, the Council Secretariat has become the core of the evolving EU foreign policy machinery.

While it is possible at each instance of institutional reform to point to a certain alignment of member state positions on the institutionalisation of CFSP, it is nevertheless striking how this process has enhanced the institutional standing of the Council Secretariat. Assuming that Council Secretariat officials are involved in matters of treaty reform with inter alia the interests of their own institution at heart - an assumption not too radical to make in the light of what we know from the study of bureaucratic politics and institutional analysis - then it is difficult not to conclude that their objective has been achieved.

In addition to the changes resulting from the Amsterdam Treaty, there have been further developments since the decisions at the 1999 Cologne and Helsinki summits to provide the Union with a military dimension in 
order to acquire a capability for humanitarian intervention the so-called Petersberg tasks. The organisational changes required to build up this capability include the creation of new working groups in the Council - the Political and Security Committee and the EU Military Committee - and the building up a military staff component in the Council Secretariat. This process has been aided by the appointment of Solana as Secretary-General of the Western European Union and the partial transfer of tasks and resources from that organisation to the Council Secretariat (Presidency, 2000). This whole process is continuing and somewhat open-ended since the precise nature of arrangements with NATO - the sharing of assets and the degree of autonomy of EU structures from NATO - remain subject to debate.

The Council Secretariat's acquisition of an operational role in the management of CFSP and ESDP is a major departure from its traditional role in the EU's institutional architecture. What needs to be emphasised at this point is that what at one level appears to have been a jewel in the crown of policy-making which has been snatched away from the Commission, has also proved to be a somewhat poisoned chalice. Gaining a role in CFSP has created certain tensions for the Council Secretariat which are not too unfamiliar for students of the European Commission. Indeed, the occurrence of certain institutional pathologies are strikingly similar to problems which we have seen in the Commission for some time, and on a larger scale. The problems arising from these changes can be summarised as follows: greater internal fragmentation, greater scarcity of resources, the co-existence of conflicting institutional cultures and logics within the same institution and greater demands on internal co-ordination.

As is implicit from what has been said so far, the 'old' Council Secretariat has drawn its political influence 
from working behind the scenes, away from the public limelight. Much of its influence is being executed indirectly, via the Presidency. Its organisational culture has been based on legalism - a comprehensive knowledge of EU law at all levels, its application and interpretation. The arrival of the a substantial number of officials working on foreign policy matters has added a contrasting dimension to this. Activity, if not activism, in foreign policy has heightened the profile of the Council Secretariat and turned the public spotlight on some of its activities - an unfamiliar and perhaps unwelcome development for the established bureaucracy. The increasing presence of military officers seconded from national forces to make up the new EU military staff has added further unease, given that it brings with it very different working methods.

The internal tensions resultant from these changes affect key aspects of the institutional life of the Council Secretariat. These can be summarised in the following table: 


\begin{tabular}{|c|c|c|}
\hline & 'Old' Secretariat & 'New' Secretariat \\
\hline $\begin{array}{l}\text { Administrative } \\
\text { function }\end{array}$ & $\begin{array}{l}\text { Legislative } \\
\text { drafting/ } \\
\text { policy-advice }\end{array}$ & $\begin{array}{c}\text { Operational/ } \\
\text { policy-management }\end{array}$ \\
\hline $\begin{array}{c}\text { Substance of } \\
\text { policy-making }\end{array}$ & $\begin{array}{c}\text { 'Bureaucratic': } \\
\text { Activities concern } \\
\text { legalistic and } \\
\text { rule-centred } \\
\text { environment }\end{array}$ & $\begin{array}{c}\text { 'Diplomatic': } \\
\text { Activities concern } \\
\text { relatively unregulated } \\
\text { environment }\end{array}$ \\
\hline $\begin{array}{l}\text { Degree of } \\
\text { hierarchy in } \\
\text { internal } \\
\text { proceedings }\end{array}$ & $\begin{array}{l}\text { Relatively low: } \\
\text { important role of } \\
\text { informal networks }\end{array}$ & $\begin{array}{l}\text { Relatively high: } \\
\text { need for formal } \\
\text { command structures }\end{array}$ \\
\hline $\begin{array}{l}\text { Degree of } \\
\text { transparency of } \\
\text { internal } \\
\text { proceedings }\end{array}$ & $\begin{array}{l}\text { Traditionally low, } \\
\text { but need to } \\
\text { demonstrate } \\
\text { greater openness }\end{array}$ & $\begin{array}{l}\text { Very low, with } \\
\text { preparations to achieve } \\
\text { greater secrecy }\end{array}$ \\
\hline
\end{tabular}

Figure 3 Administrative differences between 'old' and 'new' parts of the Council Secretariat

Given the Council Secretariat has, in the past, been a comparatively small and cohesive institution, the presence of such different organisational logics within the institution are bound to create tensions. To name just one example: what may have been regarded, at first sight, as a minor disagreement about the degree of administrative transparency has already erupted as a major issue about the EU's military effort to maintain secure communications which will ultimately require the move of military units to a 
designated security HQ of the EU. This development constitutes a first physical split for the institution and further demonstrates the fragmentation - or incomplete integration - of the institution. This echoes the experience of the Commission where the location of DGs in separate buildings has reinforced intra-institutional boundaries. At the same time, the issue has raised the opposite concerns elsewhere, i.e. that the Council Secretariat is moving backwards on the issue of transparency, despite assurances to the contrary (General Secretariat, 2000).

Indeed, what we seem to be witnessing in the case of the Council Secretariat is the construction of two separate administrative structures which are only very loosely integrated at the top. One, the 'new' Council Secretariat, headed by the SG/HR for CFSP and consisting of the policy unit and the military staff. This part of the Council Secretariat is in rapid expansion and, given the uncertainties about the future direction of EU foreign, security and defence policy, in search of a clear role and identity. The 'old' Council Secretariat, on the other hand, headed by the Deputy Secretary-General and consists of the legal services and the sectoral DGs assisting the Presidency, the various Councils and working groups in first pillar matters. There is a fairly clear dividing line between the two, even though they are formally part of the same administration.

The way in which new structures have been added in a gradual manner, and the speed with which the institution has expanded, have raised demands for a reform which would deal with current or anticipated problems and inefficiencies of the Council's structure and working practices. As a matter of fact these problems result not only from the addition of new responsibilities to the Council Secretariat but also from the fact that up till now - much 
like the Commission - the Council Secretariat had never undergone any fundamental reform since its inception. And enlargement is bound to add further pressures and tensions to the Council's and the Council Secretariat's procedures and working practices. Arguably, enlargement will be a greater challenge to the Council than to any other of the EU institutions.

A first attempt to encourage the reform of the Council was made with the drafting of the so-called Trumpf-Piris report in 1999 which acknowledges some of the problems of the Council's working methods, and the need for reform (Secretary-General, 1999). It did follow in the footsteps of demands for reform made outside the institution, but most of its recommendations were not followed up by positive responses from member states. A second report on Council reform will be presented by Secretary-General Solana to the European Council in the course of 2001. Beyond that, even more far-reaching reforms are set to be proposed at the Laeken European Council in December 2001 and implemented during the Spanish Presidency in 2002.

\section{Intra-institutional Politics: Towards coherent governance?}

Both Commission and Council face serious issues of internal fragmentation. In the case of the Commission, internal fragmentation, a long-standing and latent problem has more recently become an issue of institutional survival. Lack of coherence was a major contributing factor in the Santer Commission's crisis. Subsequent and ongoing reforms have demonstrated the continuing challenge of achieving greater coherence in the Commission. The thrust of a range of internal reforms has been to achieve greater 
vertical integration of Commission activities, and while in due course these changes may take effect in terms of a more coherent institution, they have served, in the short run, to amplify the problem.

The Council Secretariat, on the other hand, is in a period of fundamental change, facing a series of serious challenges and far-reaching reforms. Having made effective use of its resources in the past, the Council Secretariat has seen a period of rapid expansion and increasing political weight as a result. Yet, expansion has come at a price as internal fragmentation has increased: The Council Secretariat needs to find ways of reconciling differing organisational cultures and adapting to the spotlight of wider public attention that comes with the involvement in the politically highly sensitive areas of CFSP and ESDP.

The challenges and problems which the Council Secretariat has been facing are not altogether different from those which have confronted the Commission for some time. Institutional growth and expansion of competences, generally considered as signs of success, have left their mark on the institution and now threaten the maintenance of coherence, just as they have done in the Commission. The Council Secretariat may not have gone through the kind of crisis the Commission has been facing since 1999, but it is nevertheless in the grips of a need to reform and adapt to the changing circumstances of the time which is quite as serious as that of the Commission.

Over the 1990s, as the pace of European integration has picked up, the size of the Union increased and its range of policies expanded, the individual institutions have suffered the consequences of success. The have become larger and more unwieldy, while at the same time being assigned an ever-increasing range of tasks and responsibilities. As a consequence, greater efforts have been 
necessary to achieve or maintain internal coherence, and in a number of instances, most notably in the case of the European Commission, the 'cost' of reduced coherence have become evident. However, as noted at the outset, the question of coherent governance of the EU implies the examination of inter-institutional relations as well as internal politics, before broader conclusions can be drawn.

\section{Relations between Commission and Council Secretariat: Inter-institutional Coherence?}

The analysis of the Commission-Council Secretariat relationship will proceed in two steps: first, this section will identify a number of contexts in which the two institutions 'meet' and which therefore provide arenas for interaction and thereby opportunities for the generation of either conflict or co-operation. Second, the following section will seek to conceptualise this relationship in a way that moves our understanding beyond traditional images of institutional rivalry, on the one hand, and the need for fusion in order to achieve coherence, on the other.

\section{Commission-Council Secretariat relations in the $E U$ policy-process}

Commission and Council Secretariat co-operate on a regular basis in routine first pillar policy-making in the preparation and in the running of the multitude of meetings within the Council structure. Both institutions share an interest in the smooth running of the policy-process. An effective management of EU affairs can be expected to heighten the problem-solving capacity of the European level and will therefore assist the legitimacy of EU 
institutions. Both Commission and Council Secretariat have therefore to gain from the successful passage of a directive, and to lose from a failure. Clearly not any agreement in the Council is a guarantee of effective policy-making, but on the whole a perception of purposeful action is seen to be more desirable than one of inactivity.

In terms of the substance of policy-proposals, Commission and Council Secretariat may, on occasion, have different interests, but beyond such differences both will be united by a common desire to influence dynamics in the meetings of Council working groups to achieve the required consensus or majority, as the case may be. The search for compromise in the Council requires efforts at mediation which involve both the Commission and the Council Secretariat in different ways (Fouilleux et al., 2001). Both institutions have representatives in any meeting held under Council's rules of procedure, i.e. from working groups and COREPER to the actual meetings of ministers. This, in itself, establishes a continuous presence by Commission officials in the proceedings of the Council and thereby ensures regular interaction with Council Secretariat staff.

The significance of Commission intervention at the decision-making stage in the policy-process, when proposals have formally left the Commission and are under deliberation in Council and EP, depends both on the policyarea and the decision-making mechanism applicable in any given case. If decisions are to be taken by the co-decision procedure, for example, the Commission's leverage is enhanced by its opportunity to change the proposal in the course of proceedings, in order to adapt it to the emergence of a relevant majority in the Council. Further co-operation between Commission and Council Secretariat (as well as Presidency and EP) is called for in the context of the 
trialogue - the getting together of the three institutions in order to search for compromise once legislation has reached the conciliation phase of the co-decision procedure. In different circumstances, however, the role of the Commission may well be less prominent.

In any case, the influence the Commission can have in this process in mediating among different member state positions can be amplified by the Council Secretariat. The Council Secretariat, as explained above, has a role to play here too, but this will depend to a large extent on the readiness of the Presidency to rely on the services and the advice of the Council Secretariat. Different Presidencies handle this relationship in different ways. It is common practice, however, for a working relationship between all three parties - Presidency, Commission and Council Secretariat - to develop. This working relationship can extend to the detailed preparation of meetings, including the exchange of information regarding different national positions in the items on the agenda and the agreement on strategies to overcome opposition from one or the other member state delegation.

As far as the Commission and Council Secretariat are concerned, the co-operation in such situations can amount to a division of labour. The Commission's contribution is of a more high profile nature, in a more formal search for common ground among member states, with the result of the exercise finding its way into the formal proposal. Once proposals have reached the Council, the Commission's room for manoeuvre is limited, in part because it will feel bound by the fact that it has adopted its own institutional position on the issue in the College of Commissioners. At this stage, Council Secretariat staff (as well as the Presidency) can take over mediation efforts in a more subtle way, via the running of the meetings, the 
drafting of minutes and position papers and the provision of legal advice. To the extent to which such strategies have been agreed in advance of any meeting, such a 'division of labour' between Commission and Council Secretariat can be highly effective, playing to the strengths of either institution.

As is evident, such a modus operandi relies only to a very minimal degree on formal rules of procedure or on treaty provisions. It really depends on personal contacts between the relevant DGs in Commission and Council Secretariat, and the extent to which the personalities on either side are willing and able to work together. As has been argued, institutional dynamics point towards cooperation between officials from Commission and Council Secretariat, and only in rare cases will there be formal impediments to such co-operation. Yet whether it actually takes place depends on the specific actors concerned, and it is here that individual officials can make a difference for the better as well as for the worse. In any case, the emphasis in co-operation between Commission and Council Secretariat in routine policy-process is on informal contacts and, in a wider sense, the presence of networks which across the institutional divide.

\section{Commission-Council Secretariat relations in the treaty reform process}

The EU's treaty reform process is, of course, distinct from routine, day-to-day policy-making. Yet there are also a number of parallels, and these extent to the co-operation between the Commission, Council Secretariat and Presidency in the search for consensus among member state positions in the course of an IGC. In fact, to mention these three institutions in the context of Intergovernmental 
Conference may strike some as odd, but the participation of supranational institutions in the process of treaty reform is becoming increasingly recognised, thanks also to contributions from the actual participants of the proceedings (Dinan, 2000; Petite, 2000; Gray and Stubb, forthcoming; Christiansen and Jørgensen, 1998, Christiansen, forthcoming).

Obviously, the Commission is in a fundamentally altered position here, given that it does not posses the monopoly of initiative familiar from routine policy-making. Indeed, its participation in meetings is less of a right and more of an established practice. The Council Secretariat, on the other hand, is more empowered here than it may be in normal decision-making given that its staff, the legal service in particular, will be closely familiar with the subject-matter under discussion. Subject to the arrangement found with the Presidency, the Council Secretariat - acting as the Conference Secretariat - may have an influential role in the drafting of the treaty (Gray and Stubb, forthcoming; Stubb, forthcoming).

There is a greater propensity for issues under discussion in an IGC have a divisive effect on CommissionCouncil Secretariat relations, since treaty changes are more likely to affect the institutional balance than is secondary legislation. This may constitute a barrier to co-operation, but there are still areas which constitute positive-sum games for the two institutions, and where both can benefit from the exchange of information about the likelihood of agreement being reached among member states, and the way of securing such agreement.

In terms of the dynamics of IGCs, two aspects deserve specific emphasis here. First, the legal nature of the subject matter places legal advice in an even more privileged position than it is in routine policy-making. 
Given the rotation among countries holing the Presidency, the permanency of Council Secretariat's and, to a lesser extent, the Commission's legal service occupy a rather central position in the proceedings of an IGC. Second, the Commission, while not possessing a vote - and therefore no veto over any final outcome of the IGC - is nevertheless more than just a by-stander. The Commission's opinion may have an integrative effect on the course of negotiations. In particular, the Presidency, in searching for a compromise solution, will be keen to have the Commission on side. A Presidency proposal which has support from the Commission has much greater legitimacy, and therefore chances of success, than one opposed by the Commission.

Despite the very different legal and political circumstances, the dynamic here may therefore be quite similar to the need for extensive, informal co-operation between Presidency, Commission and Council Secretariat in routine policy-making. The main proviso here is that there may be more numerous exceptions to this in areas where the institutional interests of Commission and Council Secretariat come into conflict. One such example - the institutionalisation of CFSP - will be discussed in some little more detail below.

\section{Commission-Council Secretariat relations in the management of the EU's external relations}

Whereas in the legislative process and in the treaty reform process Commission and Council Secretariat have distinct responsibilities which lend themselves to informal cooperation and division of labour arrangements, the situation is rather different in the area of external relations. Here there is much greater propensity for the two institutions to develop a competitive approach given the overlap in 
responsibilities. Given the institutional dynamics involved in this area, the achievement of the treaty demand for coherence or consistency has been a growing concern (Tietje, 1997; Duke, 1999).

The treaty provides no clear division of competences, and there has been much debate about the potential for rivalry and conflict between the two institutions - and the two individuals Patten and Solana. Certainly, sensitivities and suspicions are detectable on either side. In the Council Secretariat, there is a perception that the Commission is defensive about the potential loss of influence in external relations as the Council Secretariat builds up its institutional strength in this respect. On the Commission's side, concerns are being voiced about the dangers of duplication of tasks and expertise.

The appointment of Javier Solana and the changes in the Council Secretariat that went with it have ruffled feathers in the Council Secretariat as well as in the Commission. However, with Nice having come and gone without any change in these arrangements, there is a greater sense of acceptance of the new structures and a willingness to make them work. Initial inter-institutional friction related to the financing of second pillar operations (Monar, 1997) has been largely overcome A co-operative attitude has prevailed, both at the political level where Patten and Solana have struck up a collegial working relationship and at the official level where consultation and co-operation across institutional boundaries have become common place.

Commission-Council Secretariat co-operation here has some formal aspects, but is on the whole a question of informal contacts and ad hoc meetings to address specific issues. Given the nature of the policy-area, co-operation is to a large extent problem-driven rather than process-driven, and has been most intensive in cases of crisis, in particular 
with respect to EU policy on the Balkans. Either side professes a recognition of mutual dependence between the institutions. The Commission acknowledges the formal competence of the Council Secretariat and the value of its direct links to member states' foreign ministries - a link that is strengthened by a significant proportion of Council Secretariat officials in the CFSP area being seconded national diplomats. The Commission also appears to have given in to demands from the Council Secretariat that Solana be accorded a senior status in the diplomatic protocol to Commissioner Patten, even though this breaks with past inter-service convention.

The Council Secretariat, on the other hand, clearly accepts the expertise and the resources the Commission possesses in the area of external relations. The Commission controls the key instruments in gathering information and projecting EU influence abroad. The network of delegations across the globe, providing the Commission with direct information about the conditions 'on the ground' (Bruter, 1999), are recognised as valuable by the Council Secretariat - as is the Commission's co-operation in making these available to the Council Secretariat: an agreement among member states, Council Secretariat and Commission to provide the policy unit with regular despatches from national embassies or, in the case of the Commission, from its delegations has been fully implemented only by the Commission. Most importantly, there is a recognition in the Council Secretariat of its own lack of resources and the Commission's relative wealth of them. Effective external action of the Union requires the use of instruments such as financial or technical assistance, humanitarian aid or economic sanctions. The Commission's role in the control of access to them leading to a recognition in the Council Secretariat of the desirability of involving the Commission 
in the planning and deliberation of integrated crisis management responses in the future.

Among the formal mechanisms of CommissionCouncil Secretariat co-operation is the membership of representatives from both institutions in the new Troika created by the Amsterdam Treaty (and consisting also of a Presidency representative). The Troika is an instrument of external representation - it constitutes a joint EU delegation abroad and is, as such, not intended to provide a forum for internal EU co-operation. However, the Troika provides a regular meeting place for Commission and Council Secretariat and the preparation of any foreign mission of the Troika will therefore offer opportunities for policy-coordination between the two institutions.

The second and arguably more regular and comprehensive contact between Commission and Council Secretariat is the Commission's membership in Council working groups, much like in the first pillar. This includes the Political Committee and the new Political and Security Committee. The Commission's role here will be different from that in the first pillar working groups as it lacks the monopoly of initiative in this context. But the Commission's participation still allows for a two-way exchange of information and as such assists the cooperation between the two institutions.

A sensitive point here seems to have been the extension of such co-operation into the military field, in particular given the opposition of some member states to the inclusion of the Commission in meetings of the new EU military committee. Due to these tensions the Commission has not, as yet, participated in any meeting of EUMC, but reserves the right to do so if its participation is called for in view of the specific agenda for individual meeting. But this seems more of a transitional problem as new military 
structures are being created. The is no doubt on either side that, in the medium to long-term, the Commission's participation in EU crisis response planning and execution is not only desirable but essential.

Finally, among the formal mechanisms of co-operation is the mutual secondment of officials between the Commission's DG EX and the Council's Policy Unit. This affects only a limited number of officials and is regarded with some scepticism on either side, given the detrimental impact that secondment has on the prospects for promotion and compliance with staff regulation. Nevertheless, to the extent to which it is practised, secondment adds a valuable channel of communication between the two institutions.

This observation leads to the recognition of informal networks stretching across the institutional divide. Just as in other policy-areas, these are prominent in this area, and officials working in a specific area of CFSP will be in daily telephone and email contact with their counterparts in the Commission. Again, such contacts may be suffering from personality clashes, or may benefit from the chemistry among the officials involved. In general, though, they tend to be an effective means in order to overcome the formal distance between the institutions, and the difficult hierarchies involved on either side.

By way of conclusion of this section we can say that the Commission-Council Secretariat relationship has not been without its problems, something that was to be expected given the radical nature of the changes introduced by Amsterdam. On the whole, though, institutions and officials have coped comparatively well with the tensions built into the formal arrangements. A number of channels of communication have been opened up on different levels, and they provide scope for the regular exchange of information and the preparation of joint action in case of 
crisis. But personal contacts rather than formal structures constitute the backbone of inter-institutional co-operation, particularly when Commission and Council Secretariat are required to react collectively and quickly to a crisis situation in the area of foreign policy field.

Given the joint responsibility for external relations, it is remarkable how limited the formal structures of policyco-ordination between Commission and Council Secretariat are, placing high demands on officials to network informally. At the highest level, this state of affairs has turned the spotlight on the personal relationship between Patten and Solana, highlighting the fact that the two are very different personalities who have, despite differences in political beliefs and in style, developed a professional and collegial relationship that has not witnessed any major crisis that would have been spelt 'incoherent EU foreign policy' to the outside world. In any case, on the basis of the information discussed here, the relationship between Patten and Solana, as the one between the Commission and the Council Secretariat in general, does not seem so problematic as to warrant the call from Commission President Prodi to merge the two jobs by creating a Commission Vice-President for foreign affairs - a demand that not only seems utopian in the context of current institutional developments, but may also have been counterproductive in provoking a hostile reaction from the Council Secretariat (as well as from the member states).

\section{Inter-institutional relations: Towards coherent governance?}

So far, the story has been one of a structurally determined tension between two institutions which appears to be managed rather well, even be overcome, by the policy- 
makers involved. Officials have been developing collegial approaches to their work in areas of shared responsibility, and have overcome the lack of formal structures of cooperation and co-ordination by resorting to informal networking.

Three concepts can be advanced in support of this argument that an ideational structure facilitates the cooperation between Commission and Council Secretariat: first, a shared allegiance as civil servants of the EU, second, a experience in working within a common bureaucratic culture and, third, the presence of an epistemic community of experts in the highly technical matter of EU policymaking.

The recognition of a shared allegiance concerns officials working in Brussels and who identify primarily as EU officials rather than Commission or Council Secretariat officials. In other words, a common allegiance to the EU may override more narrow institutional identities which may separate them. The development of such a shared allegiance among Commission and Council Secretariat staff lies in their participation in very similar daily routines and the presence of technical and legal expertise on important matters of EU politics in both institutions. The former, which could be termed the 'Brusselsisation' of EU officials, refers to the common experience of working in a multilingual, multi-national working environment of an international institutions. At a more practical level, EU officials have to pass similar entry requirements and concours and are governed by the same staff regulations.

This observation is complemented by the recognition of the expertise which Commission and Council Secretariat staff share with respect to certain EU matters. This may not apply to all areas of their work, but to some which - it can be argued - are important to their 
institutional self-perception (and therefore to the generation of a sense of shared allegiance). This concerns, in particular, the knowledge of the rules and procedures of EU decision-making, ranging from policy-making in the first pillar to the modalities of treaty reform in IGCs. In contrast to the substantive issues involved - on which the expertise of other actors in the policy-process is probably greater both Commission and Council Secretariat, as managers of the process, have unrivalled knowledge not only of the technicalities of the process of decision-making, but also of the origins of the rules governing this process.

Finally, the effects of this 'Brusselsisation' - the exposure to similar work (and life) routines - and membership in such an epistemic community contribute to the generation of an allegiance to the EU and to the integration project. This shared allegiance, and the resultant promotion of a common identity as EU officials - in opposition to the partisan identities of Commission and Council Secretariat - provide the environment in which cooperative action by individual actors can take place.

\section{Conclusion}

The present examination of internal politics in, and relations between, Commission and Council Secretariat has demonstrated the nature of this challenge over the past decade. Given that this is only a partial perspective on the wider issue of coherence in the Euro-polity, only limited conclusions can be drawn at this stage. The internal fragmentation of the Commission and the Council Secretariat (as that of other EU institutions) has increased. The growing size and expanded range of policycompetences has affected both to some extent. And while in 
the Commission the divide between administrative services and political level has been a problem which ongoing reforms seek to bridge, the Council Secretariat is having to accommodate the internal changes resulting from the rapid expansion of its competences in the field of foreign and security policy. The problem here is, as it has been in the Commission, that the differing organisational logics of distinct administrative tasks constitute internal tensions which then require substantive institutional resources for their resolution.

With respect to inter-institutional relations, the situation is different. Against a background of reduced expectations, Commission and Council Secretariat manage to co-operate well in areas of shared responsibility. Policymakers here rely on informal relations in order to help bridge the inter-institutional divide, and such relations build on the broad foundation of a shared allegiance to the European project and a more specific commitment to, and knowledge of, the details of specific policies under deliberation. Consequently, the coherence of interinstitutional relations - at least among these two institutions - is not as elusive as the formal institutional arrangement would lead us to expect.

One tentative conclusion which can be drawn from these observations concerns the EU's response to institutional size: the analysis here suggests that, while there are increasing problems to internal coherence, interinstitutional relations have been managed comparatively well, at least without the fundamental threats to coherence that may have been expected. If this is the case on a broader scale, the EU may be better served by more, but smaller, more self-contained and therefore more coherent institutions rather than the established institutions suffering from increasing problems with internal fragmentation. This 
means in practice that, for example, a splitting off of the CFSP/ESDP aspects of the Council Secretariat and the creation of a separate foreign policy body of the EU may be a legitimate consideration. As far as the Commission is concerned, these observations about institutional coherence may engender similar thoughts about the issue of 'unbundling' of Commission tasks - devolving specific tasks currently carried out by the Commission to separate institutions.

Given the manifold divisions, cleavages and tensions running through the Euro-polity and its institutions, there are clearly persistent and inherent challenges to the achievement of coherent governance. At the same time, however, there are established and strong, albeit informal, links which help to bridge such divisions and which assist the search for coherence. The ongoing institutional reforms which have been discussed above will have an impact on this situation, both in terms of their intended effects and their unintended side-effects. More significantly, the prospect of enlargement, implying the further growth of institutions and their internal diversity, will further muddy these waters. Even in the limited perspective offered here, the coherence of governance is a complex issue exhibiting unexpected features. A more comprehensive perspective will need to conduct more detailed research along both dimensions examined here, as well as the coherence of governance across different levels of the Euro-polity. 


\section{Chapter 7}

\section{The Role of Supranational Institutions in EU Treaty Reform}

Why should we look at the role of supranational actors in EU treaty reform? Intergovernmental Conferences (IGCs) are 'intergovernmental' and, we are told, their negotiations are "dominated by national governments" (Moravcsik and Nicolaïdes 1999: 69). Such a conclusion of the analysis of an IGC (in this case leading to the Amsterdam Treaty) is not surprising, given a liberal intergovernmentalist approach which sets out to "[explain] the national preferences of the major governments,... the bargaining outcomes among them ... and the choice of institutional solutions to implement them" (ibid.: 59). With national governments holding centre stage, other actors - including supranational institutions - end up with marginal roles in the bargaining game In fact, according to this kind of analysis, "supranational intervention ... is generally late, redundant [and] futile" (Moravcsik 1999: 269-270) 
This chapter, developing further ideas first presented in Christiansen (2002), takes issue with such a state-centric perspective, not (necessarily) because of a disagreement with its conclusions but because of the limited assumptions on which it is based. There are a number of reasons as to why these assumptions ought to be questioned, but two are of particular relevance for the present purposes here.

First, the focus on 'bargaining' is, in itself, a limited perspective which implicitly privileges the role of national governments in a particular phase of treaty reform. Treaty reform and IGCs are not only about 'bargaining' but are part of wider process comprising issue-framing, agendasetting, decision-making (at different political and administrative levels) as well as implementation and legitimation. Indeed, treaty reform is a continuous process in which IGCs and their final 'summits' are particular phases. They may have special significance, but they are, nevertheless, inextricably linked to the developments preceding and superseding them. Arguments about the relative weight of different actors in the 'bargaining' about substantive issues in IGCs neglects this procedural nature of treaty reform and thereby skews the role of other actors in them.

Second, IGCs are not an open arena for national governments to debate, and to bargain over, their respective positions and 'institutional choices'. Instead, the IGC is an institution in its own right, in which the behaviour of participants - national as well as supranational - is subject to numerous rules (Sverdrup 2000; 2002; Christiansen, Falkner and Jørgensen 2002). There is one well-known and basic rule - the requirement of unanimity among member states in order to reach a decision about treaty change. However, there is a host of detailed rules governing the 
negotiations, comprising secondary legislation, soft law and administrative practice as well as acquired cultural and social norms. In fact, the pursuit of treaty reform via the IGC format is an important, albeit implicit, institutional 'choice', deserving analysis of the role of the various actors in its design.

These arguments justify a call for a more comprehensive approach to the study of treaty reform, one that moves beyond the limitations of traditional approaches by including the study of the role of supranational actors alongside that of state actors (Beach 2005). In the following, this chapter sets out to identify the key supranational actors in EU treaty reform and examines their involvement in the process. By way of conclusion, the chapter assesses the respective contributions made by supranational institutions to the process of the treaty reform and reflects on this development in the light of the experience of the negotiation of the Constitutional Treaty.

\section{Supranational agency in the process of EU treaty reform}

This understanding of IGCs follows the broader theoretical approach developed elsewhere in this special issue (Christiansen, Falkner and Jørgensen 2002). It is an approach which seeks to move the analysis of treaty reform beyond the limitations of traditional, state-centric approaches. This has both structural and actional implications for the conduct of empirical research, but for the purposes of this chapter the adoption of such a perspective is relevant and useful because it expands research avenues into the role of agency - that of 
supranational actors - in treaty reform which are foreclosed by more traditional approaches.

However, it needs to be emphasised that the argument here is not one about the dominance of either national governments or supranational institutions in IGC negotiations. Such conclusions are a matter for empirical research in each and every case. The argument here is a conceptual one - that a systematic analysis of the role of supranational institutions in EU treaty reform is not only promising, but indeed necessary. Only the inclusion of supranational actors in the analysis of treaty reform will ensure that the subject is treated in the encompassing manner it deserves.

In the following, the chapter will look in more detail at the role of the various supranational institutions in EU treaty reform. These include the European Commission and the European Parliament, both of which have representatives participating in the actual negotiations and who also have a role to play in the wider process of treaty reform. Perhaps less obviously, this includes also the General Secretariat of the Council of Ministers which, by providing the Conference Secretariat of the IGC is intimately involved with the running of the IGC.

This inclusion of the Council Secretariat may require further justification since it is not usually regarded as either 'supranational' or as an 'institution'. It is the case that the Council Secretariat is not one of the official institutions of the EU (as listed in Art.5 TEU), but merely an organ of the Council of Ministers. However, in spite of the official nomenclature, the Council Secretariat is clearly an institution, possessing a formal structure with a set of internal rules and administrative practices which regulate the work of a body of permanent staff. And it is located at the European level, possessing a degree of institutional 
autonomy and therefore ought to be regarded as supranational. The matter is confused by the fact that the Council of Ministers is generally regarded as an intergovernmental institution, which appears to pitch it against the supranational institutions of the Union. But the status of the Council is not as clear-cut (Christiansen 2005a), and indeed the entire Council, not only its Secretariat, can be seen as supranational (Wessels 1991).

As will be argued in more detail below, the role of the Council Secretariat in IGC negotiations is closely linked to that of the Presidency. The Presidency, of course, carries special responsibility for the IGC, and could also be conceptualised as a supranational institution, even though it is carried out by a national government. The duality of the Presidency as being both supranational and national is exemplified by the different roles played by member state officials or ministers, on the one hand, and Presidency representatives, on the other. However, while the Presidency is a mixed category, it will not be covered here in depth, except where its participation in IGC negotiations has a bearing on the role of the Council Secretariat.

Other supranational institutions also have a role in the wider process of treaty reform, though not in the more narrowly defined proceedings of the IGC. The European Court of Justice has contributed substantially to the reform of the treaties. Indeed, one of the most important developments with regard to the treaty base of the European Union - the constitutionalisation of the treaties - is due to the case law of the ECJ rather than the decisions taken in the IGC format (Christiansen and Jørgensen 1999). As Greve and Jørgensen (2002) have also argued, treaty reform - and the involvement of the ECJ in this process - can be seen as constitutional politics. Given that the role of the 
ECJ has been covered by these previous contributions to the literature, it is not part of the focus of this article.

Finally, bodies such as the Court of Auditors, the Committee of the Regions (CoR), the Economic and Social Committee (ESC) have a potential role in treaty reform, formally by issuing institutional opinions and discussion papers on the IGC or particular issues under negotiation. The impact of these is doubtful, however, and in any case is different from the direct and personal involvement of representatives of the institutions mentioned above. Both CoR and ESC, as well as the EU's Ombudsman, were invited by the Convention drawing up the Charter of Fundamental Rights to present their views, but that was neither a particular privilege (since numerous other bodies and NGOs enjoyed a similar status) nor was it formally part of treaty reform (given that the Charter is not part of the EU treaties).

For present purposes, therefore, the article concentrates on the contribution to treaty reform made by the European Commission, the EP and the Council Secretariat - the three institutions which need to be regarded as the three main supranational actors in the process of treaty reform negotiations. However, before examining the role of these actors in the treaty reform process, we need to maintain an awareness of the way in which the negotiations are structured. Of particular significance here is the "negotiation environment" and the fact that these are "multi-level negotiations" (Stubb 1998: 15-17).

IGC negotiations are conducted on three different levels - official, ministerial and summit meetings (Forster 1999; Stubb 1998). The dynamics of negotiations on each of these levels are very different. On the political level, the IGC involves meetings of foreign ministers (monthly on the 
fringes of the General Affairs Council) and summit meetings of heads of state or government (at regular or special European Council). The foreign ministers' meeting is widely regarded as the least effective level, given the lack of time (usually one hour per month) to make headway in the negotiations (Gray and Stubb, 2002) Actual political guidance and decisive positioning is therefore left to the European Council were final bargains are struck and where the threat of national vetoes - and of the ultimate failure of the talks - weighs heavily.

On the level of officials - the 'personal representatives of the heads government' and their advisers - meetings occurs on a weekly basis, but contact via email, phone, etc. is practically continuous. Ideas, proposals, drafts and reactions to drafts are constantly being exchanged, and the intensity of these contacts at the official level may rival or even eclipse the intensity of contact of officials within their institutional bureaucracy (interviews with conference participants). Here negotiations move slowly but methodically through the issues under debate, (re)constructing the agenda, shaping decisions, indeed, where possible, taking decisions in advance of formal approval from the political level. The political level is left to debate, and to decide on, those issues which could not be resolved by officials. While it is the 'grand bargaining' at the political level that is the traditional focus of intergovernmentalist theorising, the more mundane, slowmoving and technical negotiation at the official level clearly has its place in treaty reform. As we will see below, the difference in the length of these processes - on the official level months or years, on political level hours or days - has a major impact on the nature of negotiation, and on the role of supranational actors in them. Clearly, EU treaty reform negotiations are more complex, and involve more levels, 
than the liberal intergovernmentalist image of 'two-level' games suggests (Falkner 2002b).

The analytical challenge in this respect is not in deciding whether the political or the official level of negotiations is more important, but rather to establish the relationship between them. At the extreme, the link is a weak one, whether that is because months of negotiations are "thrown out of the window" by the European Council (Gray and Stubb 2002: 8) or because the political leaders don't even discuss the issues on which agreement has been reached previously. But apart from such extremes, there are linkages between political and official levels, which means that a comprehensive analysis of treaty reform will need to look at both levels in order to come to a balanced judgement. Thus, in looking at the role of supranational actors in these negotiations, we will also focus on both the official and the political level. Clearly, the opportunities for, and implications of, their involvement are very different on either of these two levels of negotiation.

\section{The European Commission and EU Treaty Reform}

The significance of the European Commission in the EU's policy-process is well-documented and widely recognised. Even though the Commission does not actually decide on secondary legislation, its monopoly of initiative provides it with immense power to influence the shape of policies and thereby have an impact on the process of integration which is independent of that of the member states (Christiansen 2005b). Additional resources, including its relations with interest groups and its role in monitoring compliance with EU legislation also help to put the European Commission at 
'the heart of the European Union' (see, for example, the contributions to Nugent 2000 or Holman 2000).

With respect to treaty reform, the picture is different. Clearly, the Commission is not as central here as it is in the day-to-day policy-process. There is also much less empirical study of its involvement in IGC negotiations, though recent research has sought to redress the traditional paucity of research on Commission activity in the context of IGCs, albeit with contrasting results. Whereas liberal intergovernmentalists, as mentioned at the outset, have dismissed the potential of 'informal entrepreneurship' by successive Commission Presidents (Moravcsik 1999, Moravcsik and Nicolaides 1999), other authors have painted a more nuanced picture and argued that the Commission's presence in the negotiations makes a difference (Ross 1995, Dinan 2000; Christiansen and Jørgensen 1998; Gray 2001; Budden 2002; Falkner 2002a).

This section, in seeking to conceptualise the role of the Commission in treaty reform, will look at the following aspects: first, the Commission's internal management of participating in the negotiations; second, its potential for influence the course of the negotiations, distinguishing between the different dynamics of the political and official levels; and third, the Commission's role in the legitimation of the result of any treaty change. The key arguments made here are that the importance of the Commission as an actor in treaty reform is derived from a) its potential for advocacy and leadership before and during the negotiations; $b$ ) the involvement of Commissioners and officials in the social process which long-term negotiations constitute; and c) its part in the legitimation of treaty reform and of its outcomes. These are arguments which relate to, but go beyond, the recognition of the Commission's role in the liberal intergovernmentalist design (Moravcsik 1999: 276). 
The internal distribution of responsibility has changed from one IGC to another, but the Commission President takes overall charge of its negotiating stance. In the past two cases, the IGC was part of the portfolio of a specific Commissioner (Oreja during the 1996-97 IGC, Barnier during the 2000 IGC). In addition to the cabinets of the President and the Commissioner responsible who shadow the negotiations, a designated IGC Task Force conducted the day-to-day management of Commission input in the negotiations, overseen by a steering group composed of senior officials. It was on this level that the bulk of internal Commission decision-making took place in these IGCs (Gray 2001).

However, much depends on the Commission President, in order to raise the public profile of the Commission's input, to ensure coherent and consistent negotiating line and to translate the role played by the Commission on the official level into results on the political level, especially in the context of the European Council. In the aftermath of the crisis of the Santer Commission and the dismissive treatment of the Prodi Commission - and of Prodi himself - by the French Presidency at Nice, the role played by Jacques Delors in IGCs is easily forgotten. Unlike Santer and Prodi, Delors had a close and personal involvement in all aspects of the IGC negotiations, and managed an enormous amount of detail with the help of a small group of close advisors (Ross 1995). In that respect, he provided considerably greater personal input and topdown supervision of Commission involvement in treaty reform than either of his successors.

As a result, the experience of the IGCs leading to the Single European Act (SEA) and to Economic and Monetary Union (EMU) demonstrated not only how the Commission under the resourceful and effective leadership 
of Delors was able to influence the substantive proceedings in these negotiations, but indeed how instrumental the Commission was on these occasions in order to launch the process of treaty reform and bring it to a successful conclusion (Dinan 2000). The "entrepreneurial success" of the Commission on the occasion of the SEA negotiations is acknowledged even by intergovernmentalists, though here it is considered to be a rare and exceptional event that was not repeated on previous or subsequent occasions (Moravcsik 1999: 299).

In fact, the Commission's very 'right' to participate in IGC was established in the 1985 IGC. It is still not a formal provision of the treaty, but an established practice. This is due not only to the precedent which Delors established in the course of the SEA negotiations, but also to the acknowledgement among member states that the Commission presence during the IGC is desirable, whatever disagreements individual member states have with the position taken by the Commission on specific issues. But with the waning of the Commission's political weight from the end of the Delors tenure onwards, its ambition - and its influence - in IGCs has also been reduced. Neither the Santer nor the Prodi Commission entered their respective IGCs with anything like the clout of the first Delors Commission. This is, on the one hand, a reflection of the significance of the personal qualities of the Commission President - and Delors leadership credentials are well documented. Indeed, Delors was particularly strong and influential in European Councils - the arena in which the Commission possesses the least formal powers. But it is also a reflection of the interaction between the general climate of the integration process, and the Commission's place therein, and the fortunes of the IGC negotiations. 
It is evident here that the Commission's participation in IGCs has served two distinct functions: on the one hand, to provide substantive inputs to the debate, in order to further the communitarisation of the integration project. On the other hand, the Commission can make a useful contribution to the negotiations in its traditional role as a mediator and broker among different member state positions. This twin role, however, creates a tension in the perception - and self-perception - of the Commission's role in the IGC process, as these two roles are, to a significant extent, mutually exclusive: while a well-defined and officially sanctioned position may strengthen the hand of the Commission's negotiators in terms of pursuing that specific agenda, it weakens their ability to mediate between different and possibly opposing positions among the member states. Mediation is an important part of the Commission's role in the IGC, but the explicit statement of aims contained in its Opinion makes it difficult to appear as a mediator, and even more so to act as an 'honest broker' (Gray and Stubb 2002).

This tension between contrasting roles in the negotiations goes some way to explain the difficulty of assessing the Commission's influence in the IGC: if 'successful' as a mediator, the Commission may well fail to pursue its own agenda, and vice versa. Statements about the 'success' or otherwise of mediation efforts are therefore very difficult to make, given also that this role can be taken over more effectively by other players, in particular the Council Secretariat and the Presidency.

If at all, mediation by the Commission is more likely to occur on the official level, where a number of other factors come into play. On this level, for example, the role of expertise and of ideas have a greater influence on the course of the negotiations. Though this depends on the 
subject-matter under discussion, the dominant negotiating style and the individuals involved in the negotiations. If conditions are right, the possession of specialist knowledge about the issues being debated and the provision of good ideas about possible solutions may be divorced from the power associated with member states.

Admittedly, this may not be the typical situation in the IGC, but nevertheless certain aspects of IGC have these characteristics. It is in such situations that the quality of arguments rather than the political power associated with those making them carries the day. These are instances in which representatives of smaller member states or Commission officials can be especially effective - if indeed they possess the expert knowledge and/or powerful ideas which can sway the meeting (Gray 2001).

The significance of expertise is evident from the way in which the Commission's input in IGCs has been more effective when substantive issues are being debated in areas in which the Commission possesses prior policymaking experience. Thus, with regard to the SEA IGC and the IGCs on EPU (at least in areas of social policy; see Falkner 2002a) and EMU the Commission played an influential role in the negotiations, whereas - unable to match the expertise available to member state representatives - the Commission was less effective in areas like foreign and defence policy or internal security which were subject of the more recent IGCs (Dinan 2000). Numerous other factors play into the degree of the Commission's effectiveness in the negotiations, but there is a clear correlation between the tendency of the more recent IGCs to be more occupied with institutional rather than economic issues, and the decline of the Commission's influence in them. 
One area which deserves special attention here is that of negotiations about the powers of the Commission itself. Here, one would expect the Commission to be in a particularly strong position, assuming the Commission representatives' privileged knowledge of the operation of the institution, and a coherent view of its role in the EU's institutional architecture.

But in actual fact, there has been no such coherence of view as the Commission has long been divided on the question of its own size, and, as a result, it has been rather ineffective with respect to the issue of reform of the Commission which had been debated in both the 1996-7 IGC and the 2000 IGC. With respect to the question of the number of Commissioners, which was a central issue in the IGC and such a divisive point at Nice itself, the Commission did not manage to forcefully push a unified position. In fact, in the Commission's own Opinion on the IGC, two 'scenarios' rather than a single position were being presented (Commission 2000). This reflected a college of Commissioners deeply divided on this issue, and an institution that was unable to reconcile these differences and generate an effective negotiating position. As a result, in this area of central significance for its own operation, the Commission was hamstrung and reduced to reacting to the flow of the debate among member state representatives. This apparent trend in the declining ability of the Commission to effectively influence EU treaty reform has continued, if not deepened, with the more recent European Convention on the Future of Europe and the subsequent IGC negotiating the Constitutional Treaty. Most observers of this process have concluded that the Commission here did not manage to organise itself well for the new dynamics of this process. There was both a lack of internal coherence that prevented the development of a strong institutional position on many of the issues under discussion, as well as a 
lack of of political skill when it came to communicate any Commission position (see for example Christiansen and Gray 2004; Kassim and Dimitrakopoulos 2005; Norman 2003)

However, a different issue that can be considered concerns the Commission's role in the advocacy for treaty reform. Before substance is being discussed, the case for holding an IGC has to be made in the first place. In 1985 advocacy for an IGC was primarily provided by the Commission and based on the 'need' to re-launch Europe in the face of growing competition from Japan and the US in the global economy. The 1991 EMU IGC followed in a similar mould, and again was based on sustained pressure from Delors to complete the single market with a single currency. The IGC on European Political Union (EPU), on the other hand, was a reaction to the end of the Cold War and to German re-unification. Both Amsterdam and Nice have been presented as responses for the 'need' to prepare the EU for enlargement, though critics have complained that neither treaty reform has fully achieved that aim.

The 'need' for an IGC, however, is a matter of political judgement rather than an objective choice. The national veto, which elevates the position of member states once negotiations have begun, is suspended here: IGCs can be called on the basis of a majority vote. Rather than requiring consensus among member states, the launch of an IGC depends on the generation of sufficient momentum among governments that ensures support among the majority of member states. Pressure for treaty reform can come from a number of quarters, be it national governments, supranational institutions or indeed NGOs and civil society generally, and the Commission has always been at the fore-front in making the case for reform. 
This is not a formality. In the past, plans for IGCs have had to face scepticism, hostility and opposition from individual member states, and even though the spotlight tends to be on the discussions and the decisions during the IGC, the actual calling of an IGC is a decision that arguably at least as important. In the cases of the Amsterdam and Nice IGC (and of the IGC 2004) this has been less of an issue since provision for them was made in previous rounds of treaty reform.

Thus, advocacy for treaty reform may have become less important in the course of the 1990s, as the timing of future IGCs has become part of each treaty change, generating a sense of inevitability that one instance of treaty reform will follow the next. By the same token, however, the need to legitimise IGCs has become more important. Citizens wonder why it is that, as soon as one set of treaty changes is ratified and being implemented, discussions about the next are about to be begin. In fact, in the case of the Nice Treaty, the 'post-Nice process' involving a wideranging debate about the future of Europe is in full swing when successful ratification of the treaty is nowhere in sight (thanks also to the Irish electorate).

A quick succession of IGCs can be rationally explained, and may indeed be legally required, because of 'leftovers' - items which cannot be resolved in one IGC and therefore are being postponed to a future IGC. But this is not a practice which is likely to win public approval, and neither does it lend itself to the use of national governments who seek to return to the domestic public having gained a favourable outcome at the final summit - rather than having ended up postponing contentious decisions. That is why the image of a 'new' IGC, called because of a genuine need for further reform rather than in order to continue unfinished business, is a crucial device in order to legitimate the treaty 
reform process. And in maintaining the discourse legitimating the calling of an IGC on the basis of 'need' for reform, and regarding the outcome as a success worthy of ratification, the complicity of the Commission is as important as that of national governments.

Incidentally, this argument about legitimation cuts both ways. Lack of Commission support for the IGC result generally, or lack of sensitivity for the political climate in individual member states during the ratification process can do much damage to the legitimacy of treaty reform. Thus, on both occasions when electorates have rejected the ratification of treaty change, blame has been put inter alia on the Commission: in the case of the Danish 'No' to Maastricht in 1992, Jacques Delors was alleged to have made comments about the further extension of Community competences which were regarded as damaging to the 'Yes' campaign (Dinan 2000: 265). More recently, Commission was accused of a similar insensitivity to domestic opinion in Ireland when it criticised the Irish government for unsatisfactory fiscal policies in the run-up to the Irish 'No' on Nice in 2001 (Laffan, 2000: 5).

These examples demonstrate not only the numerous ways in which the Commission is, directly or indirectly, involved in the process of treaty reform. It also drives home the earlier point about the linkages between treaty reform and policy-process. This brings us back to the starting point of this examination of the Commission's role in treaty reform: the centrality of the Commission's performance in the ordinary policy-process and in the making of secondary legislation contrasts with its more limited role in the context of IGCs. But there is no water-tight separation between these processes, and to the extent to which developments from one 'spill over' into the other, the Commission will either reap the benefits or, as the case may be, pay the price. 
Its representatives' familiarity with the organisation of the treaties, their knowledge of the substance of EU policies and the policy-making process and their experience in mediating between conflicting member state positions constitute resources which can be effectively deployed in the IGC negotiations.

\section{The European Parliament and EU Treaty Reform}

Like the Commission, the European Parliament (EP) has a role in IGCs which lacks a strong legal foundation, but is based on established practice. If anything, its foothold on a place at the table is even more tenuous than that of the Commission. Two MEPs (one from each of the two large parties) participate in the weekly administrative meetings as 'observers', but have been excluded from the informal sessions which are often more important than the official ones. During the monthly ministerial meetings on the IGC, the EP President will be invited to participate during the official opening, but then has to leave when the actual negotiations start (Gray and Stubb 2002: 3).

In the conference room, the EP observers' resources are more limited than that of any of the other participants, given their lack of access to extensive bureaucracies. MEPs have provided effective input into the negotiations, though this has been limited to the specific areas where issues of particular concern and expertise of MEPs are concerned. A case in point where the discussions in the 2000 IGC on questions relating to political parties (interviews with conference participants).

The expansion of the EP's legislative powers, from consultation via co-operation to co-decision, in the course 
of four instances of treaty change has been vast. 20 years on, the constitutional agenda of the first directly elected parliament, culminating in the adoption of the 1984 Draft Treaty on Political Union, has been largely completed. Crucially, what the parliament still lacks is a formal role in the treaty reform process, which would allow it to participate as fully in the constitutional politics of the EU as it does in the policy-process.

So far, the EP's influence in treaty reform has largely had to rely on indirect channels. Three such channels can be distinguished and need to be examined in more detail: the party federations linking the EP to national governments, the commitment of individual national governments and parliaments to support the EP's aims, and the wider appeal to European citizens to expand the EP's powers as part of a drive to enhance the democratic accountability of the EU. In addition to these channels, to be discussed below, one should also note that the EP has in several ways managed to change the way in which EU institutions interact with one another through informal arrangements. Such agreements negotiated between the EP and the other institutions have contributed to and even fore-shadowed subsequent treaty change and are therefore part of the process of constitutionalisation in the EU (Farrell and Heritier, 2003 and 2004).

The role of party federations in linking the EP party groups to national parties is increasingly evident. These federations constitute a two-way channel between the national and the European level: political parties in the member states will seek to influence 'their' MEPs, but MEPs in turn will communicate the nature of EU debates, and the need for transnational party positions to their domestic party headquarters. Moreover, party federations have helped to integrate political parties in the EU 
horizontally, engendering communication and exchange between national parties within the same party families and thereby helping to establish transnational party positions on EU issues. The EP party groups have had a crucial role in the process of Europeanisation of political parties.

With regard to the process of treaty reform, this has meant that party federations have the potential to contribute to the search for compromise solutions in the IGC. With respect to the SEA IGC, for example, research points to the influence exerted by the European Peoples' Party over the national governments headed by their constituent parties (Budden 2002). Similarly, in the run-up to Nice, Socialist leaders, including the premiers of eight member states, and including the head of the Socialist group in the EP, met in Biarritz in preparation for the discussion on the IGC and the European Council there (Party of European Socialists 2000). It is difficult to assess the direct impact of such transnational party meetings on the ongoing negotiations, though it can only be supportive of the search for compromise, working as they do as a counterweight to the entrenched national perspectives on the issues under debate.

The EP's constitutional agenda has predominantly focused on the identification of a 'democratic deficit' in the EU. The existence of such a 'democratic deficit' in the EU has long been acknowledged, among observers and policymakers on the European level as well as on the national level. The issue had been thrown in stark focus when, after 1979, the EP was the only EU institution being directly elected, yet had little say in the making of legislation having a direct effect on European citizens. In response not only to demands from the EP - most explicitly in the form of the 1984 Draft Treaty - but to a general recognition that the legitimacy of the integration process required greater 
attention to its democratic credentials, the EP's powers have gradually been expanded.

The EP thus benefited from the effects of a public discourse about the EU's 'democratic deficit'. This discourse has been wide-spread and deeply entrenched ever since the mid-1980s. As such it is an example of the kind of collective idea, discussed in the introduction to this special issue, which hardly needs to be explicitly invoked - it has become part of the public understanding of the way in which the EU works. Even though the diagnosis underpinning the 'democratic deficit' contains several distinct problems, including, for example, the distance between citizens and EU institutions, the lack of transparency of the Council of Ministers or the unelected nature of the European Commission, discussion about remedies has concentrated on the expansion of parliamentary powers. Little has changed on these other fronts of the democratic agenda, yet the powers of the parliament have changed beyond recognition.

Clearly the EP has benefited from the way in which it (as well as other actors) has managed to establish a link between a general public discourse about European democracy to a specific programme of institutional reform. However weak or ineffective the EP may have been in the proceedings of IGCs itself, it has undoubtedly been successful with respect to agenda-setting. Evidence for this is particularly strong when, as was the case in the preparation of the IGC 1996-7, the IGC is preceded by a period of institutionalised deliberation about its agenda. Thus, one observer, while admitting the weakness of the EP representatives during the IGC itself, has pointed out that they were "very influential" in the Reflection Group, and that many of the ideas of the socialist EP representative in 
the Group were to be found in the Group's report (Stubb 1998: 19).

In the course of IGC negotiations, collective ideas, promoted inter alia by the EP, about the need to counter the EU's 'democratic deficit' have had to be translated into political action. Here, all governments have, over time, come to accept that something would need to be done about the EU's lack of democratic accountability, in particular after the Danish people's 'No' to Maastricht and the effect this had on the legitimacy of the integration process more generally. But while all member states have eventually come to agree (or accept) to the need to expanding the powers of the parliament, some have stood out as 'champions' of the EP. Initially, i.e. on the occasion of the 1985 IGC, this was Italy, no doubt also because Altiero Spinelli, the MEP who had who masterminded the 1984 Draft Treaty, commanded strong loyalties in the Italian parliament.

The support from Italy included a commitment to ratify the treaty revision arising from the IGC only if also the EP itself gave its approval. This commitment, since then accompanied by a similar pledge from the Belgian legislature, provides the EP with an indirect veto over the results of treaty change. It is difficult to assess the strength of this, as yet, untested, quasi-veto: on the one hand, the EP has tended to make substantial gains in the course of treaty reform but, on the other, the EP has not actually voted against instances of treaty revision even if they did not meet its main demands.

The potential of this 'indirect veto' for the EP has been evident again in the aftermath of the Nice Treaty, which had been criticised by MEPs immediately after the summit (European Parliament 2000, para.4). German EPP Members of the Parliament linked demands for the 
inclusion of specific aspects of the EP agenda in the debates and negotiations of the post-Nice process with the threat of a vote against the treaty (European Voice 2001c), and the composition of, and input into, the Constitutional Convention subsequently did increase the role of the EP in treaty reform significantly. This demonstrates to what extent the negotiations of one IGC may lead to (perhaps limited) treaty change, but that their after-effects have a habit of 'spilling over' into the preparation of the next round of negotiations. The EP, even though it does not possess a formal 'veto' can be an effective player in this process.

The Convention itself was, of course, to a large extent dominated by MEPs and members of national parliaments. As such, the EP did indirectly contribute significantly and successfully to the agenda-setting that preceeded the IGC. The deliberative dimension of the new convention format did favour the logic of normal parliamentary work, and the appointment of Giscard d'Estaing - not only a former French President, but also MEP - further raised hopes that the Convention might be a vehicle for EP influence of EU treaty reform. However, this was compromised to some extent by a number of counterveiling factors: the way in which Giscard d'Estaing chaired the plenary meetings, the fact that negotiations occurred under the shadow of the subsequent IGC, leading to a more intergovernmental logic slipping into proceedings towards their end, and the important role that the Praesidium and the Secretariat (incl. John Kerr - a former UK Permanent Representative) played in the process of negotiation (Norman 2003). Overall, the convention method has certainly enhanced the role of the EP in the process of treaty reform, but the actual experience of the Convention turned out to be a mixed picture in terms of parliamentary success, and uncertain future of the Constitutional Treaty in 
the light of ratification troubles has raised further questionmarks as to whether the EP can be an effective actor in this process.

\section{The Council Secretariat and EU Treaty Reform}

The EP's role in treaty reform contrasts with that of the Council Secretariat. Unlike the EP, the Council Secretariat does not seek undue public exposure of its role in treaty reform, concentrating instead on working quietly inside the conference room. But, like the EP, the Council Secretariat has gained additional powers and responsibilities in recent rounds of treaty revision, in particular with respect to the establishment of the EU's foreign, security and defence institutions - a development that, while reflecting concern among member states that such powers should not be accrued by the Commission, also underlines the ability of the Council Secretariat to provide institutional solutions in such a context.

Participant observers of the IGCs leading to Amsterdam and Nice Treaties have already pointed out that the Council Secretariat is, together with the Presidency, "one of the two key players" in any given IGC (Gray and Stubb 2002: 3). They also remark that there is a "fluid relationship" between these two actors, where "on some issues the Presidency takes the lead, [while] on others it is the Council Secretariat which sets the agenda." (p.3).

Staff from the Council Secretariat provides the administrative services for the IGC, in the guise of a 'conference secretariat'. As such, it's role in the IGC proceedings is similar to that in the context of secondary law-making among the EU institutions, and many of the 
routines and practices governing the IGC negotiations are 'imported' from the established practices of the Council of Ministers.

In examining the Council Secretariat's involvement in IGCs, a broad distinction can be made: on the one hand, the Secretariat provides logistical support, in terms of provision of meeting space, secretarial resources, etc. On the other hand, there is a more substantive side to the Secretariat's work. This concerns the assistance of the Presidency in various aspects of its responsibilities. This includes, most notably, the drafting of the agenda and the minutes of the meetings at the various levels of negotiation, the drafting of summary reports and work on the draft treaties - tasks which require a great deal of the 'technical' legal expertise and specialist experience which the staff of the Secretariat possess, but which are also highly sensitive and political.

Arguably the most important aspect of the Council Secretariat's role in IGCs is the provision of legal advice to the conference generally, and to the Presidency in particular. The Council Secretariat's legal service is designated at the legal service of the conference, thus gaining a privileged position, if not a monopoly, with regard to the interpretation of new or revised legal articles being discussed. This puts the legal staff of the Council Secretariat in a crucial position: in the absence of recourse to judicial review of individual aspects of the negotiation results, the 'legal advice' of the Council's legal service on proposals for draft articles is authoritative and can therefore constitute a constraint on the possibilities for treaty reform.

The Council Secretariat's acquisition of this role as the provider of legal advice to the IGC may seem like a 'natural' choice of governments, but matters are probably less innocent than that, given that such decisions concerning 
organisational detail are drafted by the Council Secretariat itself. The SEA IGC, convened under the influence of Delors' preferences for a negotiation format, was assisted by a legal service that included the legal advisers of both Commission and Council Secretariat. By the time of the next IGC, the Council Secretariat was made solely responsible for legal advice, and this has remained the practice ever since.

The capacity of the Council Secretariat to intervene in the negotiations - if requested - through the provision of legal advice stands alongside the more general, and substantive, advice the Council Secretariat staff can, and does, provide in the negotiations. Such an ability to provide advice, and the willingness of the Presidency and the other delegations to accept it, is derived from two aspects of the Secretariat's involvement in IGCs. First, the Council Secretariat acts as the institutional memory of the conference. As the official record-keeper of the conference, the Secretariat has easy access to past discussions, documents and papers, and can use these, as appropriate, in order to influence ongoing negotiations - a resource which it shares with the European Commission (Gray 2001).

A second, related, point concerns the personal experience of the Secretariat staff involved in the IGC negotiations. In contrast to the situation in member states, where political change and administrative turnover in foreign offices tend to change the composition of national delegations, the staff in the Council Secretariat unit responsible - the 'Directorate for General Political Questions' - has experienced greater continuity and therefore possesses greater personal knowledge of the past IGC record. Possessing both the institutional record of, and the personal insights into, the intricate and complex matter 
provides the Council Secretariat staff with a valuable resource in the negotiations.

However, statements about the potential influence of the Council Secretariat have to be qualified on a number of counts. First, the opportunities arising for the Secretariat staff to influence the negotiations lie predominantly in the area of fine-tuning the detail of treaty revisions, not in the decisions about the broad outlines of treaty reform. That is one reason why the involvement of the Council Secretariat has hardly reached the public limelight. Nevertheless, such influence in legal detail may have significant political significance and deserves to be addressed systematically in research on treaty reform.

A second, more important qualification concerns the Secretariat's relationship with the Presidency which, as already noted, is a flexible one. Much of what has been said above regarding the significance of the Council Secretariat's role in drafting agendas and meetings, providing legal and other advice and fine-tuning the detail of negotiations crucially depends on the permissiveness of the Presidency to provide such opportunities for influence. That is why, ultimately, we can only speak of potential influence of the Secretariat. Formally, the Secretariat is charged with assisting the Presidency, and its influence is realised if and when a Presidency does indeed rely on the assistance which the Secretariat can offer.

In the past, this is what Presidencies have usually done, though there are also noteworthy exceptions. Until the French Presidency in the second half of 2000, any period of IGC negotiations had been presided over by one of the smaller states, and these generally welcome the assistance which the Council Secretariat can provide, given the pressure on a country's resources during the Presidency. On that basis, the detail of IGC negotiations have usually been 
managed in 'Brussels', i.e. in close co-operation between the Permanent Representation of the member state holding the Presidency and the staff of the Council Secretariat. This co-operation routinely stretches to the first draft of the minutes of meetings, the conclusions of ministerial and European Council meetings or even draft treaties being written in the Council Secretariat. Given the significance which is usually attached the role of the Presidency in steering the IGC, this 'behind the scenes' influence of the Council Secretariat is remarkable, as is the lack of empirical research into the effects of such influence.

The French government, however, in taking over the Presidency in July 2000, decided to move day-to-day responsibility for the IGC from Brussels to Paris, and maintained exceptionally close control over aspects of the negotiations which would usually be done by the Council Secretariat. The French pushed the debate on the substantive issues ahead, but there were also claims that before and during Nice, that the French Presidency was heavy-handed and used - some might say, abused - the privileged position in order to further its particular agenda. In any case, this first IGC Presidency of a large member state demonstrated the ability of the state in question to take over the day-to-day running of the negotiations from the Council Secretariat - as well as the problems which such a strategy entails.

Another example of such a 'nationalisation' of the IGC Presidency was the infamous first Dutch draft during the Maastricht IGC on European Political Union. In drafting the EPU treaty in the Dutch foreign ministry, Dutch Europe Minister Piet Dankert departed sharply from the previous Luxembourg draft and antagonised the majority of member states. In the event, the draft failed in moving the negotiations ahead - in fact, they moved back to the 
previous text composed by the Luxembourg Presidency with the assistance of the Council Secretariat. Such examples are exceptions which serve to emphasise the rule, which is the close co-operation between Presidency and Council Secretariat in the drafting of treaty revisions. And they also demonstrate that a Presidency is actually more effective in moving the negotiations towards a successful conclusion if it relies on the assistance of the Council Secretariat rather than attempting to 'go it alone' (Gray and Stubb, 2002).

As the EU appears to move to a more open form of negotiating treaty change, via the debate about the future of Europe, and the adoption of a convention method to prepare the 2004 IGC, it might be asked what such changes hold in store for the Council Secretariat. One might assume that a greater degree of openness would diminish the role of the Secretariat, and therefore also its potential for influence. However, the experience of the Fundamental Rights Charter Convention already suggested otherwise. Here, again, the Council Secretariat, providing the Convention's secretariat and legal service - as they had done for the Reflection Group in 1995 (Lipsius 1995) - turned out to be an influential player in the proceedings (de Burca 2000).

The trend continued for the European Convention, though with some important changes. The Convention Secretariat was composed not only of Council, but also of Commission and EP Secretariat officials. Crucially, there was an appointed Secretary-General of the Convention (Sir John Kerr). Kerr had not been recruited from the Council Secretariat, but - as former British Permanent Representative - was used to the Council working methods. $\mathrm{He}$ is credited with playing an influential role in the Convention, not only through the effective use of the expertise at his - and the Convention President's - disposal, 
but in the course of the process also more openly as participant in the meetings of the Praesidium. Together with Giscard and the two Vice-Presidents (Guiliano Amato and Jean-Luc Dehaene), Kerr did have an important part in the successful conclusion of the Convention (Norman 2003).

The IGC then reverted back to the standard practice of having a conference secretariat which was recruited from the political unit and the legal service of the Council Secretariat. It found itself in the opposite position of the previous IGC leading to the Nice Treaty: where the French government had monopolised the Presidency input into the IGC, the Italian Presidency did provide very little political guidance and even less substantive input. The resultant vacuum was filled, to some extent, by the secretariat staff who drafted and summary reports about Member State positions and even their position papers on various issues. However, the ultimate failure of the 2003 Brussels European Council demonstrated, in the absence of the political gravitas that only the Presidency itself can provide, the Council Secretariat is as ineffective as it is when the Presidency takes over the running of the IGC altogether (see also Beach 2005). The most amenable environment for the influence of Council Secretariat offials is the 'middle way' - a Presidency that on the one hand does make use the expertise, be it procedural or substantive, of the Council Secretariat, but also has a sense of purpose in seeking to conclude the negotiations successfully. The Irish Presidency which then did achieve the success of finding agreement on the Constitutional Treaty was a good example of that. 


\section{Conclusions}

The study of supranational agency confirms the need to analyse treaty reform as a process, to consider its structural elements and the way in which structures interact with action. The present examination of the role of supranational institutions has helped to point to important aspects of the treaty reform process which are only marginally addressed by traditional analyses, if at all. In particular, four areas in which the activity of supranational actors can make a difference have been identified.

First, IGCs have a structure consisting of rules governing the interaction among players. Supranational institutions may not be strong players with respect to the negotiation of outcomes, but they have considerable influence in the setting of these rules, and therefore in the structuring of IGCs. Many of these formal and informal rules rely on established practices governing EU policymaking, and have been 'imported' as a side-effect of relying on the existing institutional structure of the EU. This includes the use of fora like the European Council and the General Affairs Council for the debate of IGC matters, the familiarity of participants - whether representing member states or EU institutions - with existing procedures but also the very involvement of supranational actors in the negotiations which have both an interest and a habit to extend these working methods to the IGC. Thus, Commission President Delors had a major role in the setting up of the first, major IGC of recent times, not only in terms of substantive issues, but also in terms of the format and the structure of the talks. Without such a strong Commission influence at that time, probably an entirely different format of negotiating treaty reform would have evolved. Less strikingly, but much more consistently, the involvement of the Council Secretariat and of its legal service have ensured 
that IGC negotiations have remained wedded to the standard operating procedures of the EU, despite their different constitutional status.

Second, a particular aspect of this institutionalisation is provision for a process of agendasetting which is fairly open, and which is also tied to the existing EU policy-process. It includes consultation of other institutions, participation of their representatives in arenas of 'structured reflection', such as the Reflection Group or a Convention, and also permits them to commission special reports from independent advisers or 'wise men'. This participation in the agenda-setting phase of the IGC in turn provides a privileged platform from which to generate a wider public discourse about the need for, and the aims of, EU treaty reform - an opportunity which Commission and Parliament have used to the full. Even if such ploys do not have a direct effect on the IGC negotiations at hand, they tend to create an air of expectation which means that issues are being addressed in a future IGC.

Third, supranational institutions have a special role in the legitimation of treaty reform, due to their particular standing among the IGC players. They stand apart because they do not possess formal veto rights over the outcome of the negotiations, but at the same time they can claim to represent the common European interest, and to protect this against the particularistic challenges by national governments. Because of this they occupy a certain moral ground (though not necessarily a higher moral ground) which may induce specific dynamics both inside and outside the conference room. On the inside, it strengthens the legitimacy of a country's, or group of countries', negotiating stance if they are able to point to support from the Commission in presenting proposals or opposition to proposals. On the outside, the verdict of Commission or EP 
on the agreed treaty change as well as their general activity within the EU have an impact, positive as well as negative, on the ratification process.

Fourth, representatives of supranational institutions in the IGC are participants in a social process. IGC negotiations are, after all, not conducted by 'member states' or 'supranational institutions', but by a select group of individuals. Accordingly, a number of observers have pointed to the significance of personal relations among the conference participants (Stubb 1998; Gray and Stubb, 2002; Gray 2001). At the same time, the duration and intensity of an IGC engenders among this group an esprit des corps. In terms of their unrivalled, specialist knowledge of the substance and working methods of the IGC, and the value which they come to attach to the outcome of treaty reform, this group can be considered as an epistemic community. This development is one particular aspect of the social process of European integration which occurs at the domestic as well as at the transnational European level - a process whose relevance for future research is recognised by rationalists and social constructivists alike (Moravcsik 1999: 302; Christiansen et al. 2001).

This transnational community of negotiators conducts the everyday IGC proceedings in the face of at times opposing political positions imposed by national capitals. Yet they are also operating in an environment in which the continuous and long-term interaction among group members becomes a unifying element and where ideas and knowledge, independent of their origin, can have an impact on the negotiations - notwithstanding the potential for subsequent vetoes or disagreements on the political levels. Examples of this can be found with respect to each of the three institutions: regarding the Commission in the case of the Single Market or monetary union; 
regarding the European Parliament in matters concerning its own competences; and regarding the Council Secretariat with respect to the institutional, procedural and legal matters.

The argument here is simply that the involvement of supranational actors in the treaty reform process matters, and that evidence of their influence can be found along a number of different avenues. This does not elevate them to the status of national governments, and the argument here is not that one or the other ought to be seen as the n-th member state in the IGC. However, their participation in the IGC has an influence on the format, the conduct and the dynamics of the negotiations. That is why their role in the treaty reform process deserves more systematic investigation. Here, only the broad outlines of the involvement of Commission, Parliament and Council Secretariat could be provided. Further research along these lines will expand our empirical knowledge about the role of supranational actors in treaty reform, and thus contribute to an encompassing understanding of this process. An aim that is all the more important as treaty reform is set to remain on top of the EU's agenda for the foreseeable future. 


\section{Chapter 8}

\section{The Process of EU Treaty Reform: Constitutionalising the European Union}

\section{Introduction}

The first few years of the new millennium have been a roller-coaster ride for the European Union. This recent period of European integration has taken place in the shadow of significant enlargement of the EU: the arrival of 25 and more member states that was seen as requiring a fundamental overhaul of the institutional structures of the Union. It was against this background that the EU launched, in the year 2000, a major revision of the treaties. And even though, at the end of that year, at the Nice European Council, a new treaty was agreed, this treaty reform did not satisfy the high expectations that had been placed in it. The changes that had been agreed were relatively modest, decisions on some key institutional issues were postponed, and the actual method of negotiating treaty change was called into question due to the lack of attention that could be given to important questions in the course of the final summit. Rather than preparing the Union for the major 
challenges to come, the experience of the Nice European Council raised questions about the status quo, and there were calls for a review of the way in the EU changed its treaty provisions.

From this comparative 'low point' the Union soon after departed to scale new heights when it launched, at the Laeken summit, a constitutional convention that set about to draft a Constitutional Treaty. And even though national governments eventually adopted, in the summer of 2004, a revised version of this treaty, the aspirations to settle the Union's finalite politique through such a 'European Constitutions' were in tatters less than a year later when the electorates in France and the Netherlands rejected the treaty in public referendums. Given the need for the ratification of treaty change in every member state in order to for it to come into effect, this result implied a constitutional crisis for the EU; it was followed, first by the insistence of the European elites to maintain the momentum and continue with the ratification effort in other member states, but later by the recognition that there was a need for a period of reflection. At the end of the period it became clear not only that the existing Constitutional Treaty could not be ratified unchanged (and that therefore a new round of treaty reform would be necessary) but that the label 'constitutional' was not, any more, tenable to describe the content of any new or revised treaty. Once these fundamental points had been accepted, the agreement on a mandate for a new Intergovernmental Conference and the subsequent negotiations of a Reform Treaty were swift, and at the beginning of 2008 the member states and institutions were confident that by the end of the year this institutional reform of the Union would (finally) be ratified.

This road to institutional reform that the Union has taken since the turn of the century, travelling along a rather 
torturous path from Nice to Lisbon, including the scenic route via the heights of formal, explicit constitutionalism, has created some interest among political scientists and constitutional lawyers studying EU reform, and reignited the debate about the underlying dynamics of European integration. This chapter seeks to contribute to this debate by viewing recent developments through the lenses of an institutionalist perspective on EU treaty reform ${ }^{1}$. Its main argument is that despite the 'failure' of the Constitutional Treaty, these recent developments actually confirm the thesis of incremental EU constitutionalisation advancing as a continuous process which involves, but is not solely based on, the revision of the treaties through negotiation in intergovernmental conferences, followed by domestic ratification.

The development and application of such an institutionalist perspective on the reform of the EU treaties is appropriate because this has traditionally been studied as a series of individual events, be it theoretically as grand bargains from a liberal intergovernmentalist perspective (Moravcsik 1998), or else empirically in terms of single case studies (Laursen 2006; Laursen 2005; Laursen and Vanhoonacker; 1992; Edwards and Pijpers, 1997; Galloway, 2001; Best et al. 2000, Mazzucelli 1997). It is the contention underlying the approach presented here that this traditional way of studying treaty reform misses out important aspects of the process, and hence only provides a partial view of the object of analysis. In contrast to this

1 The conceptual part of this chapter builds on and further develops arguments and concepts that have been previously published in a number of different papers (Christiansen and Jørgensen, 1999; Christiansen, Falkner and Jørgensen, 2004). The conceptual and empirical work on the constitutionalisation of the EU is presented in greater detail in Christiansen and Reh (forthcoming). See also Große Hüttmann (2005) for a similar approach. 
traditional perspective, the chapter therefore advances the following arguments:

first, that treaty reform is, in fact, to be seen as a continuous process in which each instance has been linked to the previous and subsequent instances;

second, that this treaty reform process is part of a wider, long-term process of constitutionalising the European Union; and

third, that this process of European constitutionalisation has both formal and informal dimensions.

It is on the basis of this conception that the chapter then looks at the recent past in order to assess the nature of developments from Nice to Lisbon. The chapter concludes by arguing that, even if the formal attempt at adopting a 'European Constitution' did not succeed, the constitutionalisation process can be seen to continue in the absence of the formal constitutional terminology. Indeed, the experience of the negotiation and ratification of the Lisbon Treaty demonstrates that the process of EU treaty reform has reverted back to the method that had been customary prior to the Laeken European Council.

\section{Conceptualising the Process of EU Treaty Reform}

To say that EU treaty reform is a process appears to be stating the obvious but adopting a procedural approach has major significance regarding the way in which the phenomenon is studied. A process-oriented perspective avoids looking at treaty reform in a static manner and instead recognises the potential linkages between the 'daily' policy-making process, the major events and the gradual establishment of a set of rules, norms and institutions 
governing policy-making in the EU. Furthermore, such a perspective forces us not only to regard both actors and structures in treaty reform as significant in their own right, but also to study their interaction over time in order to develop a comprehensive understanding of the nature of this process.

Even though the revision of the treaty has its own particular set of rules and is somewhat removed from the everyday politics of the Union, it remains closely tied to the wider process of integration, and also to the 'normal', 'everyday' process of policy-making in the EU (Wincott 1995). The conceptual divide between 'extraordinary' treaty reform and 'normal' policy-making that the traditional approach maintains therefore hinders, rather than helps, a better understanding of the process ${ }^{2}$. What is important in this context is to remain attentive to the mutual influence that treaty reform and policy-making processes have on one another - an aspect of the constitutional politics of the Union that is only captured when charting the course of treaty reform over time.

The reform of the treaty through an Intergovernmental Conference (IGC) has usually taken a number of years, considering the time required for preparation, negotiation and ratification of any change that is agreed. In the case of the SEA, the IGC itself was actually very brief, but the implementation of the legislative programme arising from it took more than seven years.

2 Liberal Intergovernmentalism views the treaty reform in terms of a sequence of three steps: first, the pluralist interplay of different domestic interests within each member state, resulting in the fixing of national preferences; second, the projection of, and bargaining over, these preferences within the European arena; and, third, the determination of European institutional choices as the outcome of this 'two-level' game. (Moravcsik 1993). 
Subsequent IGCs have tended to last progressively longer, both in terms of the duration of the negotiations, with longer periods of preparation and more lengthy and difficult ratification of the agreements reached.

While individual IGCs have become longer, they have also occurred more frequently. What was initially a rare event in the history of integration, became from the early 1990s onwards a regular feature of European politics. Since 1985 an IGC in order to revise the treaty has on average been convened every 5 years.

Treaty reform through IGCs is not only a process of change because of the close links that we discussed before between the policy-process and constitutional politics. The decisions taken in the context of one particular IGC often contained already the seeds of the next round of treaty reform. Thus, the need for, indeed the date of, the next review of the treaty had already been written into the Maastricht Treaty. To this legally prescribed continuity of reform we need to add the agenda-setting power of the 'leftovers' - unresolved issues that could not be included in one instance of reform, but which are then postponed being put them on the agenda of the following one.

Beyond the meta-process of these constitutional politics threading itself through the summits of IGCs and the valleys of the policy-process, each IGC itself is a process rather than an event, as traditional approaches would have it. The few days of the concluding summit, when statesmen and -women hammer out the final details of the treaty in the limelight of intense media interest, are only the 'endgame'. This is just one particular aspect of a much longer process that includes months or even years of preparation previously, and months, if not years, of implementation and ratification afterwards. 
Any IGC needs an agenda, and the period during which such an agenda is set begins long before the actual launch of the IGC, and may continue into the early phase of negotiations. An agenda is, logically, what determines the decision of having an IGC in the first place. The perceived need for revising the treaty rests on the desire among decision-makers to change the institutional arrangements, agree on the move of policy-areas from one legislature procedure to another, or to extend the Union's range of competences. This formal agenda is what constitutes the brief of the IGC, but the agenda-setting process also includes much wider questions such as the framing of the issues that are to be discussed, the public justification of the reform process and the positioning of the various actors in advance of the start of negotiations. The latter includes, for example, the drawing of 'red lines' by national governments - negotiating positions which are announced publicly and across which they are then not willing to retreat.

The agenda-setting phase is particularly important for those actors who do not possess formal decision-making power. Here we need to think in particular of the Commission and the European Parliament, but also of private interests, non-governmental organizations and civil society in the broader sense. The Commission and the Parliament both launch position papers in advance of an IGC, thus setting usually ambitious benchmarks of what the IGC is expected to achieve. But even earlier, both institutions as well as the ECJ may have had a significant, if largely hidden, impact on the IGC through their decisions and actions in the years preceding the IGC. Indeed, they may have been instrumental in the very decision to launch the IGC, as was the case with the Single European Act which followed the pressure of reform that had been building up after the Parliament's Draft Treaty of European 
Union and the Commission's White Paper on the 1992 Programme.

While the agenda may appear to be set largely by actors, we also need to note that external forces and structural elements contribute to agenda-setting. The abovementioned 'left-overs' and deadlines for further reform already fixed on previous occasions belong to this category, as to unpredictable events such as the 1989 fall of the Berlin Wall which hugely influenced the agenda ahead of the Maastricht Treaty, including the launch of a second IGC on Political Union alongside the one on Economic and Monetary Union which had already been planned.

The agenda-setting phase is not only an essential part of preparing for an efficient conduct the IGC, it is also a politically highly significant phase because it shapes the subsequent negotiations by specifically including or excluding particular issues. Thus governments that seek to draw 'red lines' and manage to keep the undesired reform off the agenda have achieve that objective already before the IGC has actually begun. Agenda-setting is therefore an important dimension of EU treaty reform.

The decision-making phase of an IGC begins with the formal Council decision that established the IGCs and sets out its remit. Negotiations in the IGC then usually involve three different levels: the level of Heads of State and Government (HSG) which debates key issues at least twice - at the outset and at the final summit meeting, but may also meet during the IGC to take stock and provide now impetus; the level of Foreign Ministers, who regularly review IGC progress in the context of their Council meetings during an $\mathrm{IGC}^{3}$; and, third, the so-called 'personal

3 While foreign ministers (or those ministers holding the EU portfolio in national cabinets) have a designated task in dealing with IGC matters in the Council, other sectoral ministers may of course also 
representatives' nominated by governments who collectively, in the formation of the Group of Personal Representatives, who carry out the bulk of detailed negotiations on the articles and issues in question ${ }^{4}$. On occasion, this Group may devolve the preparation of decision-taking further down to a Friends of the Presidency group or another working group that can be established for a particular issue. The Group of Personal Representatives and any such working groups it may choose to create constitute the administrative layer of the IGC negotiations. It comprises officials who are experts in the field, that is to say they are familiar with the nature of EU law and with the process of decision-making and legislation in the EU. In order for national representatives to be effective players at this level they also need to be familiar with the 'way of doing things' in Brussels. It is in this context that the institutionalist recognition of a 'logic of appropriateness' holds more explanatory power than that of a rationalist 'logic of consequences' (March and Olsen, 1989).

The ultimate aim of the IGC is, of course, to come to a consensual agreement. Any treaty change requires the signatures of all HSG and negotiations therefore occur under the shadow of the national veto. Negotiations proceed on the various levels in terms of the search for consensual agreement, which may come about for a number reasons. While on some issues there may be consensus already among the governments that a particular sector needs to be communitarised or a decision-rule needs to be

coordinate matters in the area of their competence if and when an IGC has such matters on its agenda. The case of finance ministers dealing with monetary issues is one case in point (Puetter, 2007).

4 Recent research has demonstrated the potential significance of the 'pre-cooking' of IGC decisions that takes place through the "delegated preparation" by these groups (Reh 2007a, 2007b). 
modified, in other areas there may be 'hard bargaining' among member state representatives based on opposing national positions. Depending on the distance between these positions, this may either involve compromising around a median position that is acceptable to all, horse-trading to enable different delegations to obtain gains in return for giving in on other issues, or indeed the postponement of decision-taking on issues where no agreement can be found - thus creating 'leftovers' for subsequent rounds of reform.

One important feature of the decision-making phase needs to be mentioned here: the role of the Presidency. Just as in the realm of running of the Union's 'everyday' business, the Presidency also takes the lead in all aspects of the IGC negotiations. Presidency officials are chairing the Group of Personal Representatives and working group meetings, their ministers and prime ministers the meetings their respective levels. More important still is the Presidency's responsibility to direct the negotiations between meetings, for example through the drafting of interim reports, outline treaties or draft articles. These are crucially important tools for the progress of negotiations: getting these wrong, as in the infamous case of the Dankert draft of the Maastricht Treaty may seriously jeopardise agreement, whereas skilful drafting of such texts can move negotiations ahead.

In these and other ways a Presidency puts its stamp on the negotiations and shapes the final outcome. Both in style and substance, IGCs therefore reflect the working methods and the agenda of the country or countries that held the Presidency during the negotiations (within the usual, well-known constraints that apply to all Presidencies) $)^{5}$. Once the final summit has been held,

5 See, for example, the different styles and approaches employed by the Italian and Irish Presidencies during the 2003-2004 IGC (Crum 2007). 
agreement reached and the new text adopted, the IGC comes to an end, but this is not the end of the process. Signing of the new treaty is followed by the process of ratification, which again has its own dynamics.

Actually, there is a period between the conclusion of the IGC and the signing of the new treaty, which can take between 2 weeks and several months and which is officially required for linguistic and technical editing of the agreed text. This is essentially an opportunity for lawyers and linguists to go through the political agreement that the negotiators have reached and ensure that it is recorded in precise legal language. However, beyond a purely technical exercise it is also an opportunity to negotiate further on precise details of specific provisions, as was the case, for example, after the signing of the Nice Treaty when the provisions on voting weights in the Council agreed by the IGC contained mathematical inaccuracies.

Once the treaty is then signed by the HSG is needs to be ratified in each member state. Only when ratification in all member states is completed, and the relevant documents have been deposited, will the new treaty provisions enter into force. There may have been a time in the past when the assumption was that ratification was merely a formality, but at least since the Danish 'no' vote on the Maastricht Treaty this is not a viable belief. Instead, the significance of ratification is now widely recognised, and the rejection of the Constitutional Treaty at the ballot boxes of both France and the Netherlands has been another seismic shift towards the recognition that treaty reform does not end with the signature of statesmen and -women at the European Council concluding the IGC.

The author argues that the outcome of the IGC is best understood in terms of a combination of the input from both Presidencies. 
This development points to the importance of public referendums, but these are not the only ways in which the treaty change can be ratified. The more common method is that of parliamentary ratification. Normally one would expect that to be a less hazard-prone method of ratification, given the majority support that governments usually enjoys in national parliaments. The phenomenon of minority governments, once quite common in Scandinavian countries, is not that wide-spread in recent years. But that still leaves the possibility for changing majorities, in cases where elections force a change of government between the end of the IGC and the vote in parliament.

Ratification can also be difficult if and when a government relies on a small minority and is in danger of a backbench rebellion. John Major's government in the UK is a case in point, with his slim majority putting the passage of the bill ratifying the Maastricht Treaty into jeopardy. And even in countries where the government enjoyed big majorities in parliament there is the potential for threats to the ratification if and when individual MPs or opposition parties choose to challenge the treaty revision in court.

National supreme courts have become regular points of judicial review in recent times, not only because euroscepticism has been on the rise and governments have been challenged on EU reform issues more frequently. Also, as the substance of EU reforms has had deeper implications for domestic systems, judicial review by national supreme courts has become more frequent. In a nutshell, the process of constitutionalising Europe has increasingly come into contact, if not conflict, with the constitutional provisions in the member states, thus calling on national constitutional courts to adjudicate on the ratification of far-reaching EU treaty reforms ${ }^{6}$. The

6 See the various contributions to Albi and Ziller eds (2006). 
important 'Maastricht Judgement' of the German Constitutional Court setting out the limits for further EU reform in terms of the German Grundgesetz is just one of the better known of a number of such judgements (Bundesverfassungsgericht 1994).

The ratification phase of any treaty change is important not only because problems at this point may scupper anything that has been previously agreed and send the decision-makers back to the negotiating table, if not the drawing board. But even short of that, more modest 'renegotiations' have been undertaken in order to facilitate renewed attempts at passing ratification referenda. The way in which the union dealt with the Danish 'no' after Maastricht and with the Irish 'no' after Nice are both cases in point.

Having established the different stages of EU treaty reform, and the links between them, facilitates a further conceptual move concerning the cyclical nature of this process: each round of treaty reform, and the developments inbetween each round, provides feedback into a future round. Figure 1 illustrates these dynamic relationships in the treaty reform process. 


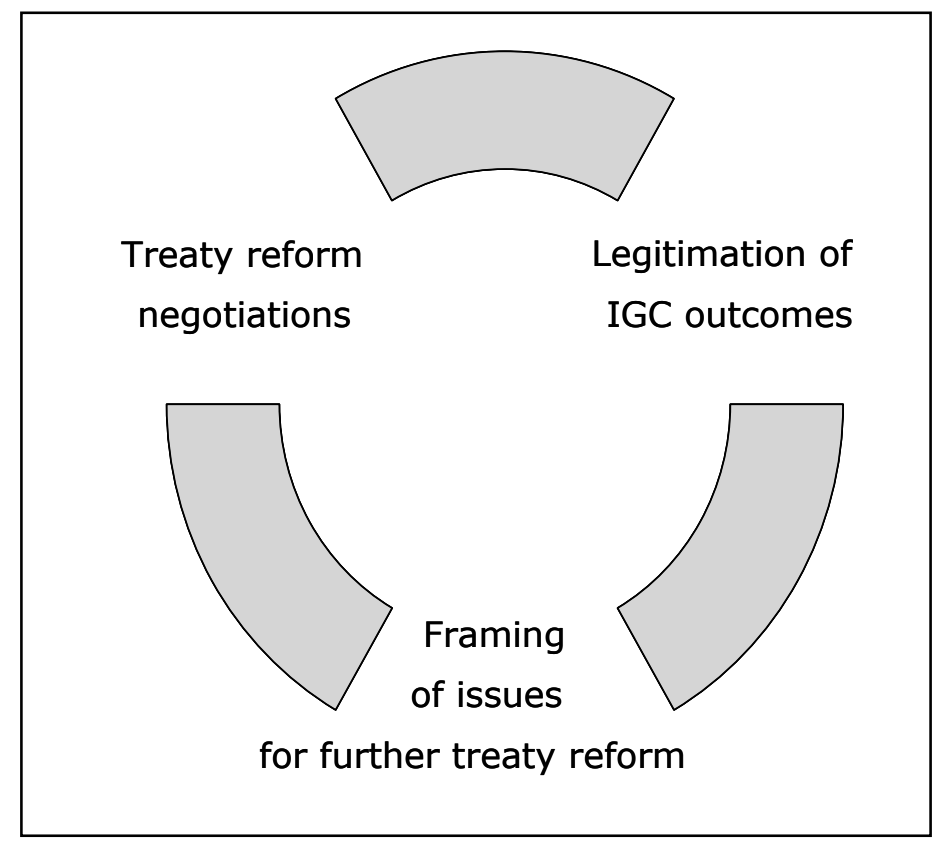

Figure 1 The Different Stages in the EU Treaty Reform Process

Adopting such an institutionalist perspective on EU treaty reform has two particular implications when it comes to identifying the forces which drive this process: first, it facilitates the expansion of the number of actors that are seen to be involved in the process, and, second, it requires the identification of the elements of structure constituting the constraints and opportunities for political action.

In terms of actorness, IGCs are traditionally seen as the business of the member states-their very name indicates that they are, by definition, intergovernmental. Indeed, most scholars would argue that it is treaty reform, more than any other aspect of EU politics, which remains the forum within which states may protect their national 
interests and shape the broad direction of the integration process. Clearly, member states play the key role in IGCs, given the need for unanimous agreement of any Treaty change. However, when looking at the various actors involved in EU reform - and in constitutional politics more generally - we quickly recognize a much more complex picture. The previous discussion already introduced the role played by European Commission, European Parliament and the European Court of Justice in the process of Europe's incremental constitutionalisation. More recent research has further established the wide range of institutional and nongovernmental actors that are involved in treaty reform and constitutional politics ${ }^{7}$.

With respect to the political structures within which treaty reform negotiations take place, a three-fold distinction between different elements can be made: first, legal-institutional structures, comprising the formal rules and informal institutions that govern the IGC negotiations; second, the ideas and discourses that provide the frame within which detailed discussions take place, and which are so deeply embedded in the consciousness of the participants that there are not immediately changeable; and, third, the temporal dimension which exerting constraints as well as opportunities through the time pressure that scheduling imposes on the negotiations ${ }^{8}$.

7 On the role of the supranational institutions, see the previous chapter in this volume (Christiansen 2002) as well as Beach (2005) for a more detailed analysis of the influence of these institutions in EU treaty reform. Individual studies of the roles played by the various institutions are contained in the special issue of the Journal of European Public Policy on 'Political Agency in the Constitutional Politics of the European Union' (Beach and Christiansen 2007) and a special section of Comparative European Politics on 'Preference Formation and the Institutions of the EU' (Dimitrakopoulos and Hussein Kassim 2005)

8 The identification of different elements of structure follows the 
The institutional context to negotiations is to a large extent set by the Council machinery. Since the SEA, during which also the Commission was involved in the running of the IGC, the 'conference secretariat' is made up of officials from the General Secretariat of the Council. Together with the Presidency chairing the meetings and the Group of Personal Representatives usually consisting of a high number of Permanent Representatives, this means that IGC sessions at the administrative level quite 'naturally' acquire the format of Council working group meetings. This includes not only formal procedures about the tabling of proposals and the management of the actual meetings but also important, if unwritten, rules of the game in the Council. One such pattern is, for example, the tendency to finding solutions for 'routine questions' at the working group level, and only to pass on dossiers to the political level as a last resort if solutions to these cannot be found among officials (Foullieux et al 2007).

The concept of institutional and legal structures surrounding treaty negotiations also includes arrangements concerning details of protocol, managing the agenda and internal communication - this 'institutionalisation' of the IGC might not influence substantive negotiations directly, but it privileges the Brussels insiders who are more at ease with these matters, and thus indirectly has an impact on proceedings.

The second element of structure, that of ideas and discourses, goes somewhat deeper than the institutional dimension. It identifies the way in which ideational discourses provide the mental frame for negotiations, permitting some ideas to influence the drafting of treaty

conceptual discussion in Chapter 1 of this volume (Christiansen 1998). The material dimension of structure has been excluded from the analysis here in order to permit a tighter focus on the other elements. 
change while others are excluded from consideration. ${ }^{9}$ This is an element of structure that has significant bearing especially during the agenda-setting and ratification phases of an IGC, but can also influence the actual negotiations. Depending on the way in which ideas and concepts are framed at the outset, specific proposals at the IGC have greater or lesser chances of being accepted and turned into concrete treaty provisions.

Finally, a third element of structure can be identified in terms of the temporal constraints surrounding the negotiations. 'Time' is, to some extent, a tool that can be used by participants, in particular the Presidency, to direct negotiations and influence discussions in such a way that it 'forces' delegations to come to a compromise. But, once employed, it also binds the Presidency within a specific time-frame that then takes on a life of its own, also binding those who originally devised it. In particular, a deadline by which an IGC is scheduled to end, structures the negotiations and creates expectations of success and failure with regard to the completion of the IGC. However, the temporal governance of treaty reform is also influenced by 'external' events, be it the EU's budgetary cycle (in particular the time-table for the revision of the financial perspectives), the EP's electoral cycle or indeed domestic political events such as important national elections ${ }^{10}$.

All these elements of structure combine to provide a framework for IGC negotiations, a structure that is to a large extent outside the control of individual actors who

9 For a discussion of the wider significance of discourses for European integration, see Diez (2001) and Rosamond. For a more specific treatment of legal and constitutional discourses in the EU, see Shaw (2000).

10 For a discussion of the more general notion of the temporal dimension of European politics, see Ekengren (2002) and Goetz (2006). 
have to accommodate their pursuit of national and institutional interests within it. Developing an understanding for these elements of structure that shape IGC negotiations is an important part of a comprehensive analysis of EU treaty reform. It is also a departure from the previous intergovernmentalist approach which saw treaty reform negotiations exclusively in terms of national preferences and bargaining among member state representatives. The wider range of actors involved, and the recognition of structural factors bearing on the negotiations, ensures that these 'blind spots' are eliminated from the study of treaty reform.

\section{The Nature of the EU's Constitutional Politics}

The previous section developed the concept of EU treaty reform and discussed the important analytical significance of this concept. One crucial aspect of this institutionalist conception of treaty reform is that it allows us to see treaty reform not only in the context of the EU's 'everyday' policy-process, but also in terms of its links to other important developments in the EU. The procedural approach is sensitive to the links between ordinary EU politics and treaty reform, but is equally perceptive with regard to the constitutional dimension of EU politics. This constitutional dimension, defined as the development of commonly agreed basic rules and norms that shape the governance of the European Union, differs in important ways from the constitutional experience of most European states. Constitutional rules and norms have developed over time, and while some of these have been enshrined in the written text of the EU treaties, others are based on less formal agreements or indeed on established practice. Constitutionalism in the EU, then, is more akin to the style of British rather than Continental European 
constitutionalism - rather than relying on a single constitutional document, it involves a number of different texts and practices.

An analysis of constitutional politics therefore also needs to go beyond the study of intergovernmental conferences and include a range of different developments. Constitutionalisation in the EU must then also be studied as a process, albeit one that is significantly broader than treaty reform. In order to approach the subject systematically, we can distinguish between the following sources of constitutional rules and norms:

- Case law from the European Court of Justice, developing important constitutional principles ${ }^{11}$

- Conclusions from the European Council and other EU summits, setting out fundamental decisions and directions for the institutions of the $\mathrm{EU}^{12}$

11 The judgements from the ECJ in the 1960s and 1970s, laying down key principles such as supremacy of EC law, the direct effect of EC directives and the origins of a human rights regime for the Community, are generally accepted now to have been of constitutional significance. Indeed it was the Court itself which, on the back of its own legislation, first started to refer to the EU's "constitutional order" - something that EU lawyers are now treating as a matter of fact.

12 The European Council has on several occasion taken fundamental decisions which has a constitutional impact on the future development of the Union. For example, the expansion of EU competences in key areas such as foreign policy (EPC) or monetary policy (ERM) was initially agreed in the context of such summit meetings. The fact that such decisions are then later codified in the context of treaty reform (CFSP and Euro, respectively) illustrates the previous argument about the link between treaty reform and other aspects of EU constitutional politics. As a matter of fact, the very creation of the European Council as an institution of the Union was initially an informal development that only much later, when it had become established practice, was formally included in the text of the Treaty. 
- Intergovernmental Conferences agreeing on treaty changes as well as European Conventions preparing these

- Key decisions and established practices by the EU institutions having constitutional character ${ }^{13}$

From this list is becomes clear that treaty reform and constitutional politics are closely linked, but that they are not the same: constitutionalisation goes beyond treaty reform, but also treaty reform includes a large number of issues and decisions which are not of a constitutional nature. This latter phenomenon is, arguably, one of the persistent problems that prevents treaty reform from becoming more transparent and more accessible to the wider public: given the size and the complexity of the consolidated treaties, these go much beyond the citizens' understanding of what is 'constitutional' 14

In adopting such a broad perspective, it becomes evident that many important constitutional developments have, in the past, taken place under the guise of 'normal' politics or as treaty reform. Through a process of "integration by stealth" (Majone xxx) the EU has, over

13 Examples for this can be found in past inter-institutional agreements adopted by Commission and EP, for instance with regard to the approval of the Commission President and individual Commissioners. Also EU legislation with constitutional implications, for example in the area of comitology, would fall in this category, as would the interinstitutional agreement on the EU's multi-annual financial perspective.

14 One frequent observation has been that the US Constitutional is comparatively compact and easily accessible for citizens, whereas the EU treaties, with their many sectoral provisions are not. With this objective in mind, but also with a view to facilitating a less cumbersome revision of the 'non-constitutional' parts of the treaties, there has been a proposal for dividing the treaty into two parts - constitutional and non-constitutional and have different revision regimes for either part (EUI...) 
time, transformed itself into a polity that is based on much more than international treaties. The changing nature of the EU, from the original international organisation towards the transnational polity that we confront today, is in part due to the continuous process of constitutionalisation that has taken place over several decades. In order to study this process - in order to study constitutionalisation as process it is crucial to establish the links between decisions taken at different points and in different fora, and then bring these diverse influences together in a single stream of constitutionalisation.

However, beyond the past informal process of constitutionalisation which remained unseen and/or informal due to the nature of the decision-making processes, there has been a more recent attempt at formalising this process. As indicated at the outset of this chapter, from 2000 onwards the EU moved towards a policy of officially constitutionalising itself, of giving itself a formal 'European Constitution'. While on the one hand, this process of formal constitutionalisation was closely linked to previous developments, it provided on the other hand a departure from past practice in a number of ways: first, there was a radical shift in the use of language, both in terms of the discourse about the text that was being negotiated and in terms of the discourse contained within the text itself; second, there was a change in the method of treaty change, in that the traditional IGC was preceded by a 'European Convention' that agreed a draft treaty which was subsequently developed further in the IGC; and, third, there was a perception in many member states that, given the formal-constitutional nature of this process, the endorsement of the people would be required in the ratification of the 'Constitution'. A large number of member states therefore held referendums in order to ratify the treaty change. 
While it is important to identify these key differences between the previous, informal aspects of constitutionalisation and the more recent, formal dimension of constitutionalisation, it is equally important to recognise the close linkage between the two. In contrast to those who have argued that the drafting of a Constitutional Treaty could be seen as a 'constitutional moment' of the European Union (Walker 2004), the view taken here is that we have witnessed 'constitutionalisation by different means', the formalisation of an already existing path towards constitutionalisation rather than a break with the past. What the developments in the period between 2000 and 2004 did was to make visible and explicit the constitutional foundations and aspirations of the European Union, when these had been previously kept away from public view. Before looking at these recent developments in more empirical detail in a moment, we have therefore identified three broad domains of constitutionalisation:

- "Formal constitutionalisation" - the explicit creation of a written constitutional document for the EU, involving a public process of deliberation and legitimated through popular vote in the member states.

- "Informal constitutionalisation through treaty reform" the de facto creation of a constitutional foundation through incremental changes to the founding treaties of the EU.

- "Information constitutionalisation outside treaty reform" - the implicit constitutionalisation of the EU through established practices and key decisions by the EU institutions and national governments with constitutional character.

Developments in each of these domains has, over time contributed to the process of constitututionalisation of the 
Union, and the accumulated effect has been the progressive creation of a constitutional order in Europe.

In terms of conceptualising constitutional politics in the EU, so far two elements have been identified: on the one hand, the very nature of constitutionalisation as a continuous process, and, on the other hand, the distinction between the different degrees of formality that have contributed to this process. in terms of conducting an analysis of constitutionalisation in the European Union, this then requires a chronological study of those decisions and other factors that have contributed to constitutionalisation, and to chart these across time in search for a temporal pattern. A schematic illustration of this conception is provided by Figure 2. It is on this basis that the remainder of this chapter will now examine the process of constitutionalisation that taken place in Europe, with particular focus on the recent attempt at formal constitutionalisation. 


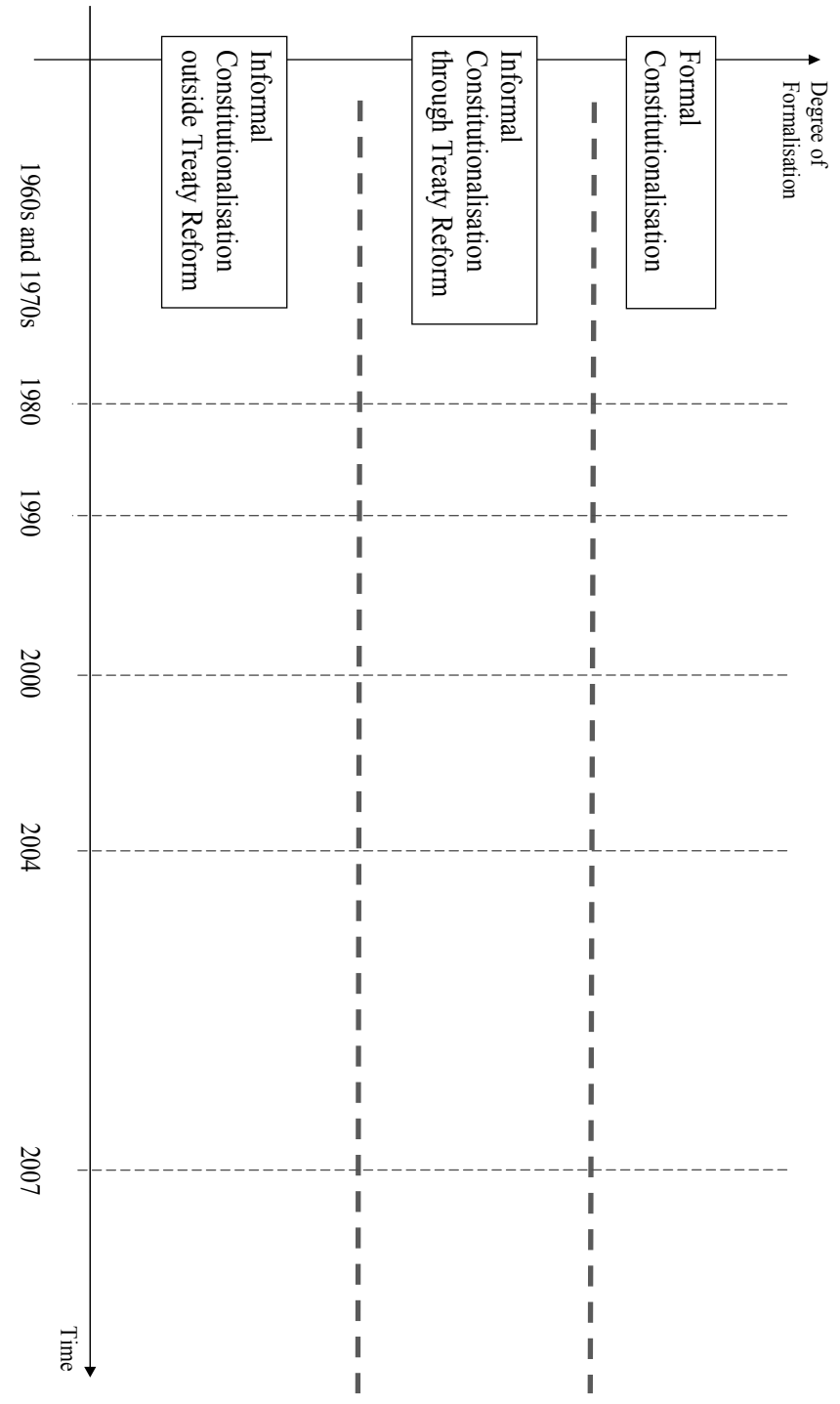

Figure 2 Conceptualising Constitutional Politics in the European Union 


\section{Constitutionalising the European Union: From Nice to Lisbon (via Laeken)}

The first observation when starting to examine the recent developments regarding the constitutional reform process in the EU is the recognition that the debate about a 'European Constitution' was deeply embedded in the existing integration process. The talk about, and the work on, a constitutional document was indeed a radical departure from the previous practice of avoiding at all cost the language, symbols and other trappings of statehood. But in spite of this discursive break with the past, there was never any serious idea to compose such a constitutional document from scratch. Instead, the debate about the 'European Constitution' that began, among the European political elites, in 2000 took account of the previously established patterns and foundations of European integration. It linked to previous aspirations of the European movement, in particular constitutional federalism; it build on the advances of European constitutional law; and it was situated within the reform debate of the European Union in preparation of Eastern enlargement. In fact, the launch of the debate occurred during the final stages of the Nice IGC and was initially seen as an attempt as an attempt to achieve a more federalist outcome of that particular IGC.

Its impact on the actual negotiations at that particular time was in fact minimal, as the IGC was too advanced in order to be able to accommodate a return to broad and far-reaching questions about the EU's foundations. The initial assessment was, therefore, that the Nice Treaty was a defeat for pro-integrationist forces and served to preserve the status quo. However, the 'defeat' of these high aspirations was only temporary, and in fact the momentum right after the Nice European Council was building for a deeper revision of the treaties. This was due 
in part because the outcome of the Nice European Council was questionable, both with regard to the content of the revised Treaty and with regard to the way in which it had been negotiated. The treaty reform, while having been launched at a major review of the institutional provisions of the Union in preparation for enlargement, failed to achieve this aim, and while there were modest extensions of codecision, most other important decisions were postponed to a future round of reform. The extension of qualified majority voting was linked to a new way of calculating the qualified majority - a triple majority that actually made decision-making more cumbersome than the previous system.

Equally damaging was the actual experience of the final summit, where negotiators spent three days bargaining over the final issues, and were seen to be more concerned about parochial interests rather than the search for workable solutions for the 'new Europe'. France, holding the Presidency, spent significant diplomatic resources on the defence of its voting parity with Germany, Belgium did the same, though with less success, vis-à-vis the Netherlands, and the then candidate states were seen to be excluded from the negotiations about arrangements that would apply to them as much as to the old member states.

The Nice summit therefore ended not only with an imperfect treaty, but also with a number of important 'leftovers' requiring further treaty change, with a desire by many involved in the negotiations to reform also the format of negotiations; and with an explicit mandate, contained in Declaration 23 attached to the Nice Treaty to launch a process to engender a wider debate about the 'Future of Europe'. In different circumstances this might not have had the consequences that it did, but given the contingencies at 
the time these developments set onto a course for a period of formal constitutionalisation.

Belgium held the Presidency in the second half of 2001, when the details of this 'post-Nice process' where being worked out, and at the Laeken European Council in December 2001 managed to achieve a maximalist interpretation of the aims of the 'post-Nice process' which included the inclusion of a possible 'constitutional document' in the mandate of the European Convention that was being agreed on. This was taken one step further by the Convention itself which, under the leadership of Giscard d'Estaing, set out to draft a Constitutional Treaty rather than providing the subsequent IGC merely with a report or a number of scenarios - outcomes that would also have been possible under the Laeken mandate.

At the Laeken Summit, another important decision was taken, namely the nomination of Valery Giscard d'Estaing as the Chairman of the Convention, with JeanLuc Dehaene and Guiliano Amato, former prime ministers of Belgium and Italy, respectively, as Vice-Chairs. Giscard d'Estaing had previously been French President, but had also served many years as a member of the European Parliament and thus combined the roles of representing both member state and EU institutional interests. A further important appointment in the Convention was that of John Kerr, the former UK Permanent Representative, as Secretary-General. He brought with him not only close connections to the British establishment, but also experience and familiarity of Coreper/Council procedures.

The European Convention thus had a strong leadership, both in political and administrative terms. Giscard had a clear vision of the direction he wanted the Convention to go, and even though he suffered certain setbacks in the closing stages of the Convention, his agenda 
of formally constitutionalising the European Union did resonate with the membership of the Convention ${ }^{15}$. The Convention was made up of representatives of national governments, members of the European Commission, members of national parliaments and of the European Parliament, and even though there were differences among its members about the substance of any draft Constitutional Treaty, Giscard's approach of seeking 'consensus' (rather than either the more formal unanimity or majority-voting) proved to be effective in achieving a final agreement.

The members of the Convention organised themselves in a number of working groups on specific, mainly sectoral issues, but due to the parliamentary majority of the membership there was also a strong partypolitical dimension to the Convention's work. In the final analysis, though, the Convention was very much a topdown affair, with a 'Praesidium' bringing together 12 key members of the Convention steering the drafting of the new Treaty (Kleine 2005). This Praesidium, which - unlike the plenary sessions or the working groups, met in private, was supported by a very effective secretariat composed of officials from Commission, EP Secretariat and, above all, Council Secretariat (Deloche-Gaudez 2005).

Giscard's handling of the Convention was controversial, also because his constitutional ambitions so explicitly went beyond the kind of treaty reform that had been initially expected. And while the draft treaty in the end did include a lot of the language of statehood (flags, symbols, a European President and Foreign Minister, European laws, a supremacy of EU law clause) he did not succeed with proposals for a re-naming of the Union as a

15 For a detailed examination of the proceedings of the Convention, see Norman (2003); for an analysis of Giscard's leadership, see Kleine (2007). 
'United States of Europe'. He was also heavy-handed in the use of his procedural resources, frequently ignoring opposition from the floor to his own preferences with regard to specific aspects of the treaty, the preamble being a case in point. Finally, he was criticised towards the end of the Convention when he was seen to consult extensively with national governments, anticipating their views in advance of the subsequent IGC, at the expense of listening to opinion within the Convention.

The European Convention therefore was not the 'deliberative forum' that many constitutionalists had hoped to $\mathrm{se}^{16}$. There was a certain degree of deliberation, but negotiations about the final draft treaty were neither fully transparent nor did they necessary reflect the substantive work that had taken place in the working groups. Still, the Convention, when it completed its work in the summer of 2003 did achieve two significant objectives: first, to actually having been able to agree on a single, comprehensive draft treaty, and, second, to have set the agenda for the Constitutional IGC that followed the Convention, and that had the formal power to agree on changes to the treaty ${ }^{17}$.

Treaty reform, as we discussed earlier, always implies an agenda-setting phase, and it is possible to see the Convention as simply a forum for more systematic agendasetting. Previous IGCs had been preceded by reflection groups, and one perspective on the Convention can be to see it as a 'super-Reflection Group'. However, given the strength of opinion, the detailed work and the high degree

16 See the discussion in Eriksen et al. (2004) and the analysis by Kleine (2006).

17 See Milton et al (2005) and Church and Phinnemore (2005) for a detailed look at the substantive content of the Constitutional Treaty. 
of consensus that had been achieved In the Convention, the approach of the Italian Presidency to minimise any changes to the Draft Treaty in the IGC appeared as an obvious choice. The Convention Draft did indeed constitute the basis of negotiations in the IGC, and even though the Italian strategy of seeking to avoid the 're-opening' of individual articles appeared to fail when the December 2003 summit ended without agreement, the following Irish Presidency then succeeded in getting agreement on a revised version of the draft treaty approved at the final summit in June 2004. Heads of State and Government then met in Rome in October 2004 for a formal signing ceremony of the "Treaty Establishing a Constitution for Europe" - a document that from then on was widely referred to as the 'European Constitution'.

While a lot of work, energy, diplomatic skill and other resources had gone into drafting this treaty, the process was still not complete without ratification. Given the constitutional aspirations of this treaty, it generated significant public interest and in a large number of member states a popular referendum was seen as the ratification method of choice. This included not only countries that regularly held referendums in the past, but also several others which had not previously submitted EU matters to such a test, and indeed some where referendums had never been held before. The Netherlands was one such case in point. France and the UK had both called referendums for reasons that were regarded as more politically than legally motivated, and in both cases doubts were raised about the likelihood of achieving a positive result of such a vote ${ }^{18}$.

18 See Closa (2007) for a detailed discussion of the motivations behind individual countries' choices in favour of holding referendums. 
In the end, it was first in the Netherlands at the end of May 2005, and a few days later in France, that the electorates of two of the original member states voted against the Constitutional Treaty. Analysis of the voting intentions and of the public debate in these countries has sought to show that the result was less a verdict on the actual text of the treaty, but was best explained by a variety of factors which included both European and domestic issues. While the 'no' votes in these tow countries were a severe shock to the 'system', there was nevertheless an immediate reflex by the EU institutions to persist with the ratification process, and indeed several countries did ratify the Constitutional Treaty in subsequent months, including Luxembourg by referendum. There had, after all, been previous precedents when initial 'no' votes had been overturned subsequently, after domestic politics had a chance to react and make arrangements for a second vote that would assure a more favourable reception ${ }^{19}$.

There was, however, also a sense that the opposition to the Constitutional Treaty had been so strong in these two countries, and that these countries were so central to the European project, that it would be difficult if not impossible to overcome this double 'no'. Also, a number of member states decided to put their referendums on hold after the rejection of the treaty in France and the Netherlands. A more concerted effort was therefore perceived to be necessary in order to keep the constitutional project going. Both the European Commission and the member states acted in response to the 'constitutional crisis'. The Commission (2005) identified a gap in the

19 Denmark initially voted 'no' on the Maastricht Treaty, and the ratified the Treaty after a second, favourable referendum, and the Irish government lost a referendum on the Nice Treaty, which was then overturned in a second referendum. 
communication between the EU and the citizens, and launched a programme aimed at enhancing the opportunity for dialogue between citizens and elites, the so-called "Plan D" (Wallstrom 2007). Governments, coming together in the European Council (Presidency 2005), agreed that what was need for a 'reflection period' which would last until 2007 and enable a possible re-negotiation of the treaty in time for the next EP elections in 2009. This period of 'reflection' about the future of the constitutional project would also, and conveniently, include the national elections that were due in both France and the Netherlands, thus allowing any new government to re-present the European issue differently to their electorate.

The reflection period, which lasted from mid-2005 to mid-2007, served the actors to buy time. During this period, the Union celebrated its $50^{\text {th }}$ anniversary, which included the adoption of a 'solemn declaration' in Berlin about the Union's values and aims, and thus provided a text with some constitutional principles (Presidency 2007). In terms of treaty change, the realisation by early 2007 was clearly that, despite previous statements to the contrary, a re-negotiation of the treaty was both necessary and possible. The German and the Portuguese Presidencies collaborated closely in order to launch a new IGC in the summer of 2007 - Berlin managing to get agreement on an extremely detailed mandate for the IGC, and Lisbon then following up on this with a conference that was concluded in the second half of the year. The Lisbon Treaty was signed by Heads of State and Government in December 2007.

A number of factors facilitated this process: there had indeed been the anticipated change in domestic politics in key countries, namely in France with the election of Nicolas Sarkozy as President. EU enlargement, which had been one of the main reasons that were given for the need 
of a fundamental, constitutional over-haul of the Union, and which had been one reason for the opposition towards the Constitutional Treaty, had happened without the Union suffering any immediate or obvious negative effects as a result $^{20}$, and Turkish accession to the EU, while still on the agenda, had clearly moved into the background of public deliberation. Above all there had been a growing acceptance among the EU's political elite that, while a reform of the treaty was still seen to be necessary, that this should rather not be presented as a constitutional project. Ratification of 'ordinary' treaty change would be more easily achieved if referendums could be avoided, and for this to be the case, the language of constitutionalism had to be replaced (Delauche-Gaudez 2007).

This reversal from the high degree of politicisation that treaty reform had 'enjoyed' during and after the European Convention, to the active de-politicisation of negotiations towards a 'Reform Treaty' is remarkable ${ }^{21}$, as is the fact that substantively the vast majority of provisions that had been contained in the Constitutional Treaty were included in the Lisbon Treaty ${ }^{22}$. The Treaty contains key

20 See Best et al. (forthcoming) for a discussion of the impact that EU enlargement has had on the workings of the key institutions in the European Union. The contributors conclude that there is no significant detrimental effect on the efficient function of the EU institutions.

21 In the Lisbon Treaty IGC, the political level was almost entirely absent, and detailed negotiations on the basis of the June 2007 mandate were conducted.

22 Most observers agree that the Lisbon Treaty is essentially the Constitutional Treaty, minus the name, the flag/symbols clause, the title of the Foreign Minister and the terminology for EU legislative acts. Ways of 'measuring' the degree of congruence between the two treaties differ, but according to MEP Alexander Stubb the Lisbon Treaty is "99.5 per cent" identical with the Constitutional Treaty. 
elements of the original Treaty that would need to be regarded as constitutional:

- the President of the Council of the European Union will be chosen by the prime ministers and national presidents for a term of 30 month. This office does not empower the elected top politician to take any executive decisions. Furthermore, the Presidency system will be revised, with representatives from three member states jointly running sectoral Council meetings over period of 18 month.

- the High Representative of the Union for Foreign Affairs and Security Policy/Vice-President of the Commission will combine the functions of the current Foreign Policy and Security Chief and the External Relations Commissioner. The powers of the High Representative are limited to implement policies, but s/he will play an important role in representing the EU's globally.

- the President of the European Commission will be elected by the European Parliament, based on a proposal from the European Council. The size of the College will be reduced from 2014 onwards. Only 2/3 of MS will have a Commissioner at any one time, rotating every 5 years.

- the Commission's delegations will form part of a 'European External Action Service' of the Union and will come under the joint responsibility of the Council and the Commission.

- the European Parliament, comprising 750 members and a President, will gain further powers as the codecision procedure becomes the 'ordinary legislative procedure' and is expanded to further areas. Additionally, the new budgetary procedure requires the 
approval by both the Council of Ministers and the Parliament.

- national parliaments also get more involved in the legislative process. They are being notified of proposed legislation and have eight weeks to deliver their comments. ${ }^{23}$

- qualified majority voting was extended to new policy areas. As from 2014 onwards, a new voting system shall be introduced: a vote is passed if $55 \%$ of MS are in favour and if these countries represent $65 \%$ of the EU's population - an element that is making the size of the country's population much more important.

- the European Court of Justice is granted enhanced powers to rule on cases dealing with EU Justice and Home Affairs legislation ${ }^{24}$. The Charter of Fundamental Rights, agreed in 2000 as a "solemn proclamation", will become legally binding with the Lisbon Treaty. ${ }^{25}$

Ratification of this treaty remains, of course, an important issue, but here the changes that national governments have made to the domestic arrangements make an ultimate adoption of the treaty by all member states more likely. All member states except Ireland have decided to

23 When $1 / 3$ of national parliaments objects to a proposal, the Commission has to consider whether to maintain, amend or withdraw the legislative proposal; when the majority of the national parliaments object, and the Commission still wants to press ahead with its proposal, the European Parliament, and the Council consider both sides of the argument and come up with a decision.

24 Special provisions were given to Denmark and the United Kingdom

25 Special provisions were given to Poland and the United Kingdom 
rely on parliamentary ratification only - something that is especially remarkable in countries like Poland, Denmark and the UK which had been previously committed to referendums on the Constitutional Treaty. Both France and the Netherlands are also not going to have a referendum on this occasion, and in all member states parliamentary majorities appear to be sufficiently strong in order to facilitate approval of the Lisbon Treaty.

The outcome of the popular vote In Ireland cannot be taken for granted, in particular after the initial rejection of the Nice Treaty, and a rejection of the Lisbon Treaty there would also be very difficult to overcome given the previous experience of an overturned referendum result. It is for this reason that the Irish government may hold the referendum as late as possible in 2008, in order to ensure that the momentum is in favour of overall ratification and thus avoiding that the Irish electorate takes the issue to the brink. Beyond the Irish referendum, there is also the possibility for judicial review of the Treaty by national supreme courts, a scenario that might be likely in both Germany and the Czech Republic. Overall, the chances of ratification are uncertain, but appear to be significantly higher than they were for the Constitutional Treaty (Duff 2007; Palmer 2007; Kurpas 2005; Hagemann 2007).

\section{Conclusions}

While the outcome of ratification, at the time of writing in early 2008, cannot be predicted, we can already say now that the Union appears to have found a way out of the constitutional impasse. The three elements that formalised constitutionalisation after the Nice Treaty - the use of the convention method for deliberation of treaty changes, the adoption of a language of constitutionalism, and - at least in 
many member states - the search for legitimation of treaty change through public referendums - have not been present any more in the (negotiation of) the new treaty. Instead, the Lisbon Treaty has reverted back to the pre-Laeken practice with regard to language, negotiation method and ratification format, even though in substance it maintains the constitutional elements that the formal 'constitution' had already contained.

This observation demonstrates that the Lisbon Treaty is, indeed, 'constitutionalisation without the name' the continuation of a process that began decades ago and is being carried forward despite the 'failure' of the formal project to design a 'European Constitution'. Our analysis, on the basis of the conceptualisation developed earlier in the chapter, has demonstrated that neither was the Constitutional Treaty a radical break with the past, nor was the Lisbon Treaty a radical break with the constitutional project. In both cases there was a huge shift in the degree of formalisation of the constitutional process - a shift that, as the politics in the ratification phase have shown, has been hugely significant - but it did not change the underlying trend towards greater constitutionalisation. The thesis of a continuous process of constitutionalisation in the European Union, taking different forms at different times, is therefore confirmed rather than disproven by the experience of treaty reform since the turn of the century.

In terms of the future outlook, we can say that the signs are that constitutionalisation will continue further, but that not only a formal constitutional project, but probably also 'ordinary' treaty reform itself, are not likely to happen in the near future, for a number of reasons. Given the torturous process by which the Union managed to arrive at the Lisbon Treaty, there is a certain degree of treaty reform fatigue detectable, both among governments and 
electorates. Even if the Lisbon Treaty is unlikely to last the "50 years" which Giscard d'Estaing had predicted the Constitutional Treaty to last without revision, governments will seek to avoid another, major treaty reform in the foreseeable future. The Lisbon Treaty is, in many ways, a much more fundamental overhaul of institutions and procedures than either the Amsterdam Treaty or the Nice Treaty were. The Lisbon Treaty also include a new article concerning the changes to the treaty revision procedure. This article (Art.33) provides for both an ordinary and a simplified procedure for changing the treaties. This means that major reform project would - again - require the convening of a European Convention, but it would also allow minor reform steps to be taken via the simplified procedure, the so-called passarelle clause, which allows the European Council, acting unanimously, to make changes to parts of the treaty, for example with regard to the extension of the ordinary legislative procedure into new areas.

If and when the Lisbon Treaty is ratified, there is then an expectation that constitutionalisation will continue further, even if the formal method of Constitutional Convention and Intergovernmental Conference is not applied. Thus, having moved from a fairly informal process of constitutionalisation to become highly formal and politicised in the context of the Constitutional Treaty, constitutionalisation is again becoming less formal in the wake of the ratification failure of that treaty. The path that the constitutionalisation process has taken over this period is illustrated by Figure 3 below. It emphasises the nature of constitutionalisation as a process, linking the various contributions that have been made to the process while also recognising the shifts in formalisation that have taken place over time. 
This analysis of EU treaty reform from Nice to Lisbon, via Laeken, confirms the key arguments that were spelled out at the beginning of this chapter: there is a very close linkage between treaty reform and constitutionalisation; treaty reform itself is best viewed in terms of a continuous process; and constitutionalisation has both formal and informal dimensions. Looking at the period from the mid 1980s until today, it is evident that treaty reform has been a constant feature of the political life of the Union during this time. The project to draft and adopt a 'European Constitution' must be seen in this context: it build on the previous rounds of treaty reform, and fuelled further treaty reform after the 'constitution' itself failed. The 'Constitutional Treaty' itself may have turned out to be a brief episode in the integration process, but constitutionalisation, albeit with a different name, is very much alive and present. 


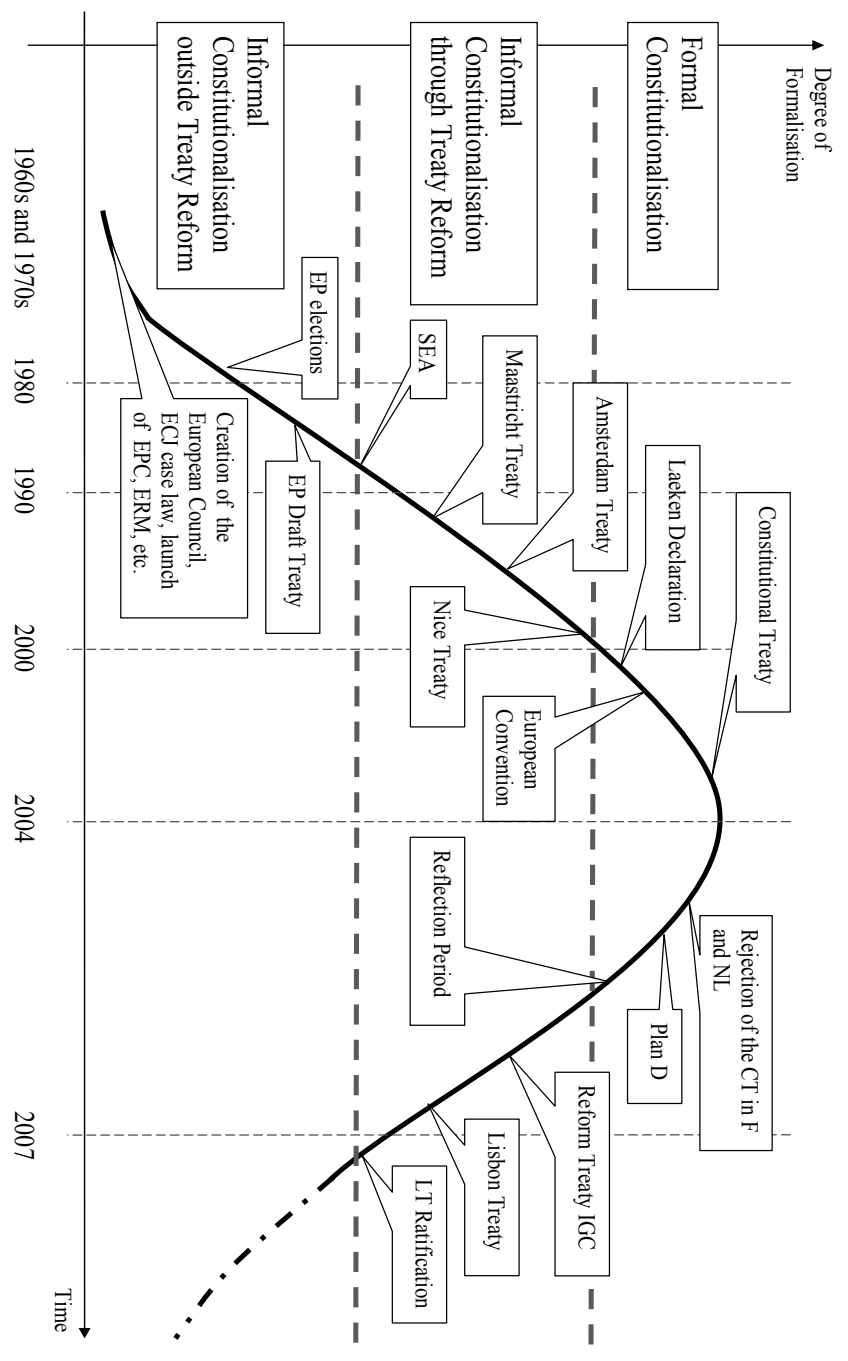

Figure 3 The Different Stages of the EU's Constitutionalisation Process 


\section{Conclusions}

The aim of this book has been to develop and apply a framework of analysis for the study of institutional politics in the European Union. We discussed, in the introduction and in Chapter 1 the need for such a framework to be sensitive to the influence of both structural and actional factors in the explanation of institutional politics. Institutions are social constructs which persist over time, and which therefore imply a degree of continuity, but which are also subject to change. In order to allow us to understand the dynamics behind both continuity and change, any explanation needs to be sensitive to the roles played by actors as well as by their structural environment.

In the framework that was developed in Chapter 1, change is being conceptualised as a number of layers, each having a different 'depth' and occurring over a different period of time. 'Shallow change', in this perspective, happens within shorter time-frames, such as in the context of EU policy-making. Deeper change occurs over longer periods of time - decades or even centuries - and involves changes to the institutional structure of the polity, and beyond that to social transformations in society. Given the centrality of time in this conceptualisation of change, the analysis of institutional politics requires a process-based approach. In other words, institutions - which can be understood either in the sociological sense of systems of 
norms and rules, or in terms of organisational units - need to be studied as processes, so that the interplay of actors and structures can analysed systematically.

The institutions of the EU - seen in the organizational meaning of the concept - are involved in all three of these dimensions of change: they are closely involved in the EU's policy-process, though to different degrees in different sectors; they are both subjects and objects in processes of institutional reform and the constitutionalisation of the EU; and they ultimately contribute to deeper social changes and the development of a European polity.

Based on this framework, this book has focused on the study of institutional politics at the intermediate level of change, i.e. the development of organisational structures and debates about constitutional reforms in the EU. In the context of an integration process which centrally relies on legal and institutional structures in order to sustain itself, the treaty base of the EU's institutional architecture is clearly of paramount importance in this regard. The EU treaties are the basis on which institutional were developed, and even if their evolution is governed also by other factors, the legal framework is an important structural element.

It is for this reason that several chapters of this book have looked in some depth at the way in which the EU treaties have been revised. In particular, we have focused on the reform of the treaties as a continuous process, which in turn is part of a wider process of constitutionalisation of the European Union. It is this conceptualisation of treaty change as process, based on the overall framework of analysis developed in Chapter 1, that the role played by institutional actors in this context becomes evident. Chapter 7 discussed in some detail the role of the supranational actors in this process of treaty reform, identifying the potential 
contribution made to the process by the European Commission, the European Parliament and the General Secretariat of the Council of Ministers. While the actual influence of each of these institutions in EU treaty reform is an empirical question that requires detailed analysis in specific areas or periods of time (an analysis that can be expanded to include other key actors at the European level such as the European Court of Justice or the Presidency), such empirical analysis can only be conducted on the basis of the prior recognition that this is indeed an area that needs to be analysed, and it is the value of the institutionalist approach developed here to be sensitive to this.

Chapter 8 provided a more detailed discussion, both of the way in which treaty reform and constitutional politics is conceptualised here, but also of the actual application of such a conceptualisation to the study of recent developments since 2000. The chapter demonstrates the close linkages between 'ordinary' treaty reform and the 'extraordinary' attempt to adopt a formal 'Constitution' for the European Union. Seen as a single process, both the previous and subsequent revisions of the treaty (at Nice and at Lisbon) are part and parcel of the formal constitutional project that was launched at Laeken and failed to materialise after the rejection of the Constitutional Treaty by the electorates of the Netherlands and France.

This institutional approach to treaty reform and the procedural conception of constitutional politics in the EU provide a much more comprehensive treatment of the subject than traditional, liberal intergovernmentalist approaches have done. The inclusion of a much wider range of actors and the recognition of the structural constraints and opportunities that have a bearing on the process, facilitates an understanding of the nature of constitutionalisation of the EU that a more narrow, interest-based approach would miss. 
The original mainstream understanding of treaty reform up to the late 1990s had been that each Intergovernmental Conference could be studied in isolation, and that the dominant driving force in explaining the outcome of each such 'bargain' was provided by the preferences, strategies and resources that the (large) member states brought to the negotiating table. There were several 'blind spots' in this theory: the neglect of European integration as a 'two-way' process in which member states bargain at the EU level, but also themselves influenced and changed through processes of Europeanisation; the influences to treaty reform arising from the policy-making and litigation before the ECJ; and the institutional and sociological factors shaping debates and negotiations before and after the IGC.

The discussion in this book, in particular in Chapters 7 and 8, sought to close this gap. While the argument provided here is a theoretical one, the evidence that this is backed by empirical observation over the last decade is overwhelming. The linkages that the institutionalist approach seeks to identify have been laid bare by the developments in the EU, most tellingly by the formal endorsement of the member states for a 'post-Nice process' linking the various stages in the attempt to formally revise the treaty towards a formal constitutional document. Thus, the conceptual move that have been advocated here, from an event-historical to an institutionalist understanding of treaty reform, has been matched by an empirical move in the political practice of the European Union itself. Further empirical research certainly needs to take place, and the ultimate destination of the constitutionalisation process remains unclear, but the case for a procedural and institutionalist approach to constitutional and institutional reform in the EU has, I believe, been made.

If Chapters 7 and 8 sought to apply the insights of an 
institutionalist perspective in order to illuminate our understanding of the wider processes of constitutional and treaty reform in the EU, the preceding chapters have addressed the internal and external workings of individual institutions in the same way. Two institutions had been singled out for a more detailed analysis: the European Commission (Chapter 4) and the Council Secretariat (Chapter 5). These are key institutions that are involved in both the legislative and the executive work of the European Union. Each hold considerable interest for the academic observer: the Commission because of its centrality not just in the policy-process, but for the overall path of European integration, and the Council Secretariat because it constitutes an important element in EU politics that remains largely under-researched.

The application of the institutionalist framework to the study of these two organisations implied a closer look at the interplay between external forces - the tensions of European governance - and their internal workings. The study of the Commission focused on the was in which different parts of the organisation have to reconcile the contradictions contained in the wider structure of the European Union. In particular, the focus here has been on the different political and administrative logics that are at play in the Commission, and which translate into internal tensions within the institutions. There clearly is both a political and a bureaucratic dimension to the work of the Commission, and Chapter 4 demonstrated the impact that this has on the internal politics of the institutions. On the one hand, tensions arising from the contradictory demands placed upon the Commission lead to persistent inconsistencies in its actions, and a case study of Commission activity demonstrated the bureaucratic politics that occur between different administrative units of the Commission. On the other hand, the Commission has 
devised mechanisms to overcome the divide between political and bureaucratic logics within its organisation, namely the central role played by the cabinets in the internal procedures and the rise of networks that transcendent different sectors and levels in the Commission hierarchy.

This study of the Commission provides a more sophisticated understanding of the nature of the organisation, going beyond the 'single actor' image that is frequently portrayed in both public debate and academic analyses. It shows the Commission to be an internally highly fragmented institution, a feature of its organisational life that also helps to explain the varying degrees of influence in the EU policyprocess that the Commission has had over time, and across sectors. The 'crisis' of the Commission in 1999, which led to the resignation of the college of Commissioners under President Santer, be seen as a consequence of such internal tensions: the collegial logic among the Commissioners being at odds with the hierarchical logic among the services, and the use of personal networks being employed in order to bridge the gulf, mismanagement could be related to the lack of individual responsibility that Commissioners and officials would take. Subsequent reforms have sought to tackle both the administrative weaknesses and the lack of political leadership in the Commission, but in the process the Commission's effectiveness in relations to other institutions and vis-à-vis the member states has suffered. This shows how the procedural approach of studying institutional change (and continuity) is a valuable guide to an understanding of the dynamics behind the Commission's changing role in the institutional politics of the EU.

One of the institutions that has risen in importance within the institutional architecture of the Union, just as the Commission has waned, has been the Council Secretariat. This organisation was studied, from much the same 
perspective as previously the Commission, in Chapter 5. Again, the internal divisions are being laid bare, in relation to the contradictory aims that the Union is placing on the institution. As the result of the acquisition of new competences in the foreign policy, defence planning and crisis management field, an increasing separation between the 'old' part of the institution, dealing with the traditional legislative work in collaboration with the Presidency, and the 'new' part under the High Representative, can be observed. And, much like in the Commission, the growth in size and diversity of tasks in the Council Secretariat can be seen to threaten the overall coherence and consistency of their work.

Traditional analyses have usually seen the Commission as a supranational institution, and the Council is regularly referred to as an intergovernmental machinery. The value of the analysis undertaken here is that is demonstrates the more complex reality of either institution: the Commission, both at the political and at the administrative level, incorporates strong elements of intergovernmentalism, something that has become more explicit in the debate about the numbers of Commissioners in the college (including the potential loss of member states having always 'their' Commissioner represented in the college). At the same time, it has also shown that the Council has an important supranational dimension in the Council Secretariat, which in some areas has become an executive branch of the Union, and thus can be seen as a sort of mini-Commission.

Given these, usually hidden, similarities between the two institutions it is less surprising then that, in terms of their co-operation with one another, there are fewer problems than are traditionally anticipated. Chapter 6 looked at this inter-institutional relationship with a view to establish 
the degree of coherence that can be found. While there is a general perception of rivalry between the institutions, we find that there is also a significant amount of co-operation, resulting in a high degree of overall coherence in the work of the institutions. This finding is related to the structural factors that were discussed earlier, namely the legalinstitutional mechanisms and the ideational constructs at play. Officials in both institutions are subject to the same expectations when it comes to recruitment and promotion, are working under similar staff regulations, and generally share the same ideas about the nature and direction of the European Union. While individual institutional affiliation clearly matters (and thus creates diverging interests and distinctive approaches to specific questions), there is a wider conception of being part of the 'European civil service' which encompasses officials in both institutions (as well as those in others).

This discussion of similarities and cooperation across two institutions often seen as rivals is valuable not only with respect to our understanding of EU institutional politics in general, but in particular at a time when a partial merger between parts of the two institutions is being considered. In the context of the changes to be introduced by the Lisbon Treaty, the High Representative (currently heading the Council Secretariat) and the Commission VicePresident for External Relations will be functions carried out by one and the same person. Underneath them, a newlycreated 'European External Action Service' will bring together parts of the Council and Commission services, and the existing Commission delegations around the word will be managed jointly by Council and Commission. While these changes are, in many ways radical, their success is conceivable against the background of the analysis of the relations between the two institutions that was undertaken in Chapter 6. 
In conclusion we can therefore say that the framework developed in this thesis, and applied to a number of institutional contexts in the European Union, has demonstrated its value. Studying institutional politics from a procedural and institutionalist perspective has given us new insights into the functioning of individual institutions such as the Commission and the Council Secretariat, it has brought about a better understanding of the inter-institutional relationship between them, and it has allowed us to develop a much broader and encompassing approach to EU treaty reform and constitutionalisation. This is the case both with regard to academic study, where this approach opens new doors and provides for original empirical work to be undertaken, but in addition it also facilitates an improved ability to assess and respond to actual policy-developments, be it at the level of individual institutional changes or at the level of EU treaty reform. As the EU is evolving further, much remains that needs to be studied and understood. But, considering the challenges that lie ahead for research on the institutional politics of the European Union, the concepts and frameworks developed here hopefully provide useful tools for those seeking to engage in such research in the future. 



\section{Bibliography}

Albi, A., and Ziller, J. (Ed.) (2007) The European constitution and national constitutions: ratification and beyondy (Alphen aan den Rijn: Kluwer Law).

Allison, G., (1971) The Essence of Decision (Boston, Little Brown).

Allott, P., (1991) 'The European Community is not the True European Community', Yale Law Journal, Vol.100, No.8, pp.2485-2500.

Alter, K., and Meunier-Aitsahalia, S., (1994) 'Judicial Politics in the European Community', Comparative Political Studies, Vol.26, No.4, pp.535-561.

Anderson, P., (1974) Lineages of the Absolutist State (London: New Left Books).

Bach, M., (1993) 'Transnationale Integration und institutionelle Differenzierung - Tendenzen der europäischen Staatswerdung', Zeitschrift für Rechtssoziologie, Vol.14, No.2, pp.223-242.

Bayer, N. (2005) 'EU 25 - Creating a New Design for the Council', Eipascope, Vol.2005, No.1, pp.8-13.

Beach, D. (2004) 'The unseen hand in treaty reform negotiations: the role and impact of the Council Secretariat.', Journal of European Public Policy, Vol.11, No.3, 2004, pp. 408-439

Beach, D. (2007) The European Parliament in the 2000 IGC and the Constitutional Treaty negotiations: from loser to winner., Journal of European Public Policy, Vol. 14, No. 8, pp. $1271-1292$.

Bellier, I., (1995) 'Une culture de la Commission Europeene? De la rencontre des cultures et du multilinguisme des fonctionaires', in Y.Mény et al., Politiques Publiques en Europe (Paris: L'Harmattan). 
Best, E., Christiansen, T. and Settembri, P. (forthcoming in 2008) The Institutions of the Enlarged European Union: Continuity and Change (Cheltenham: Edward Elgar).

Best, E. (2000) 'The Debate about the Weighting of Votes: The Mis-Presentation of Representation?', in E. Best, M. Gray and A. Stubb (eds), Rethinking the European Union (Maastricht: European Institute of Public Administration), pp. 105-30.

Beyers, J. and Dierckx, G. (1998) 'The Working Groups of the Council of the European Union: Supra-national or Integovernmental Negotiations', Journal of Common Market Studies 36/3: 289-319.

Braudel, F., (1981) On History (London: Weidenfeld and Nicolson).

Brent, R. (1995) 'The Binding of Leviathan: The Changing Role of the European Commission in Competition Cases', International and Comparative Law Quarterly 44/2: 25579.

Bruter, M., (1999) 'Diplomacy without a State: The External Delegations of the European Commission', Journal of European Public Policy, Vol.6, No.2, pp.183-205.

Budden, P. (2002) 'How 'Intergovernmental' was the 1985 IGC?', Journal of European Public Policy, Vol.9, No.1, pp. pp.76-97

Buitendijk, G. and van Schendelen, M. P. C. M., (1995) 'Brussels Advisory Committees: A Channel of Influence?', European Law Review Vol.20, No.1, pp.37-58.

Bulmer, S. and Wessels, W., (1987) The European Council: Decision-making in European Politics (Basingstoke: Macmillan).

Bulmer, S., (1994) 'The Governance of the European Union: A New Institutionalist Approach', Journal of Public Policy, Vol.13, No.4, pp.351-380. 
Bulmer, S., (1997) New Institutionalism, The Single Market and EU Governance (Working Paper No.25) (Oslo: ARENA).

Búrca, G. de. (2000) The drafting of the EU Charter of Fundamental Rights, paper prepared for the Constitution of European Democracy Conference (Vienna).

Burley, A. and Mattli, W., (1993) 'Europe before the Court: A Political Theory of Legal Integration', International Organization, Vol.47, No.1, pp.41-75.

Burnham, J. and Maor, M., (1995) 'Converging Administrative Systems: Recruitment and Training in EU Member States', Journal of European Public Policy Vol.2, No.2, pp.185204.

Burns, C. (2004) 'Co-decision and the European Commission: A study of declining influence?', Journal of European Public Policy, Vol.11, No.1, pp.1-18.

Cammack, P., (1992) 'The new institutionalism: predatory rule, institutional persistance, and macro-social change', Economy and Society, Vol.21, No.4, pp.397-429.

Caporaso, J., (1996) 'The European Union and Forms of State: Westphalian, Regulatory or Post-Modern?', Journal of Common Market Studies, Vol.34, No.1, pp.29-52.

Carlsnaes, W., (1992) 'The Agency-Structure Problem in Foreign Policy Analysis', International Studies Quarterly, Vol.36, No.3, pp.245-270.

Cerny, P., (1990) The Changing Architecture of Politics (London: Sage).

Christiansen, T., (1994) European Integration Between Political Science and International Relations Theory: The End of Sovereignty (EUI Working Paper RSC No.94/4) (Florence: European University Institute).

Christiansen, T., (1997) 'Reconstructing European Space: From Territorial Politics to Multilevel Governance', in K.E.Jørgensen (ed.), Reflective Approaches to European Governance (London: Macmillan), pp.51-68. 
Christiansen, T., (1997) 'Territorial Politics and Institutional Reform in the European Union: The Committee of the Regions at the 1996 IGC', Regional and Federal Studies, Vol.7, No.1.

Christiansen, T., (1997) 'Tensions of European Governance: Politicised Bureaucracy and Multiple Accountability in the European Commission', Journal of European Public Policy Vol.4, No.1, pp.73-90.

Christiansen, T., (2001) 'Intra-Institutional politics and Interinstitutional relations: towards coherent governance?', Journal of European Public Policy, 8, 5, pp.747-769.

Christiansen, T., (2001) 'The Council of Ministers: The Politics of Institutionalised Intergovernmentalism', in J.J.Richardson (ed.), The European Union - Power and Policy-making (2nd edn) (London: Routledge), pp.135154.

Christiansen, T., (2002) 'Out of the Shadows: The General Secretariat of the Council of Ministers', in M.P.van Schendelen and R.Scully (eds) Unelected Legislators in the European Union, Special Issue of the Journal of Legislative Studies Vol.8, No.4, pp.80-97.

Christiansen, T., (2002) 'The Role of Supranational Actors in EU Treaty Reform Journal of European Public Policy Vol.9, No.1, pp.33-53.

Christiansen, T., (2005) 'The European Commission: The Role of the European executive in the EU Policy-process', in J. J. Richardson (ed.), The European Union: Power and Policymaking, 2nd edn (London: Routledge).

Christiansen, T., (2005) The Council of Ministers: Facilitating interaction and developing actorness in the EU', in J.J.Richardson (ed.), The European Union - Power and Policy-making (3nd ed.) (London: Routledge).

Christiansen, T., (2005) 'The European Commission between continuity and change', in J.J.Richardson (ed.), The 
European Union - Power and Policy-making (3nd edn) (London: Routledge).

Christiansen, T. and Gray, M., (2004) 'The European Commission and Treaty Reform', Eipascope,Vol. 2004, No.1, pp.10-18.

Christiansen, T. and Gray, M., (2005) 'The European Commission in a period of change: A new administration for the wider European Union?', Eipascope, Vol.2005, No.1, pp.20-24.

Christiansen, T.and Jørgensen, K.E., (1998) 'Negotiating Treaty Reform in the European Union: The Role of the European Commission', International Negotiation, Vol.3, No.4, pp. 435-452.

Christiansen, T. and K.E.Jørgensen, (1999) 'The Amsterdam Process: A Structurationist Perspective on EU Treaty Reform', European Integration Online Papers, Vol.3, No.1; online at http://eiop.or.at/eiop/texte/1999 001a.htm.

Christiansen, T. and Kirchner, E. (eds), (2000) Committee Governance in the European Union (Manchester: Manchester University Press).

Christiansen, T., Wiener, A., and Jørgensen, K.E., (2001), 'Introduction', in T.Christiansen, A.Wiener and K.E.Jørgensen (eds) The Social Construction of Europe (London: Sage), pp.1-23.

Christiansen, T., G.Falkner, and Jørgensen, K.E., (2002) 'Theoretical Lenses on EU Treaty Reform: Beyond Bargaining and Diplomacy', Journal of European Public Policy, Vol.9, No.1.

Christoph, J., (1993) 'The Effects of Britons in Brussels: The European Community and the Culture of Whitehall', Governance, Vol.6, No.4, pp.518-537.

Church, C.H. and Phinnemore, D., (2006) Understanding the European Constitution. An Introduction to the EU Constitutional Treaty (London and New York: Routledge). 
Cini, M. (2000) 'Administrative Culture in the European Commission', in N. Nugent (ed.), At the Heart of the Union: Studies of the European Commission, 2nd end (Basingstoke: Macmillan), pp. 73-90.

Cini, M. (2001) The Politics of Reform: Responsibility and Good Governance in the European Commission, paper prepared for the ECPR Joint Sessions of Workshops (Grenoble).

Cini, M., (1995) Administrative Culture in the European Commission: the case of competition and environment, paper prepared for the 4th Biennial ECSA Conference, Charleston.

Closa, C., (2004) 'The Convention Method and the Transformation of EU Constitutional Politics', in E.O. Eriksen, J.E. Fossum and A.J. Menéndez (eds.). Developing a Constitution for Europe (London and New York: Routledge), pp.183-206.

Closa, C. (2007) Why convene referendums? Explaining choices in EU constitutional politics, Journal of European Public Policy, Vol. 14, No. 8, pp. 1311 - 1332.

Cohen, I.J., (1991) Structuration Theory (London: Macmillan).

Committee of Independent Experts (1999) First Report into Allegations regarding Fraud, Mismanagement and Nepotism in the European Commission (Brussels).

Coombes, D. (1970) Politics and Bureaucracy in the European Community: A Portrait of the European Commission (London: George Allen and Unwind).

Council of the European Union (1999) An Effective Council for an Enlarged Union: Guidelines for Reform and Operational Recommendations (Brussels).

Council of the European Union (2003) Multiannual Strategic Programme of the Council 2004-2006 (Brussels).

Council of the European Union Decision of the Secretary-General of the Council/High Representative for the CFSP on measures for the protection of information applicable to the 
General Secretariat of the Council (2000/C 239/01) (Brussels).

Council Presidency (1995) Progress Report from the Chairman of the Reflection Group on the 1996 Intergovernmental Conference (Madrid).

Cram, L. (1993) 'Calling the Tune without Paying the Piper? Social Policy Regulation: The Role of the Commission in European Community Social Policy', Politics and Policy Vol.21, No.3, pp.135-46.

Cram, L., (1994) 'The European Commission as a multi-organization: social policy and IT policy in the EU', Journal of European Public Policy, Vol.1, No.2, pp.194-217.

Crum, B., (2007) Can the EU Presidency make its mark on interstate bargains? The Italian and Irish Presidencies of the 2003-04 IGC, Journal of European Public Policy, Vol.14, No.8, pp. 1208 - 1226.

de Zwann, J., (1995) The Permanent Representatives Committee: Its Role in European Union Decision-Making (Amsterdam: Elsevier).

Dehousse, R., (1994) 'Community Competences: Are there Limits to Growth?', in R. Dehousse (ed.), Europe After Maastricht: An Ever Closer Union? (Munich: Law Books in Europe/C. H. Beck), pp. 103-125.

Dehousse, R., (1992) Does Subsidiarity Really Matter? (EUI Working Paper LAW No.92/32) (Florence: European University Institute).

Dehousse, R., and Majone, G., (1994) 'The Institutional Dynamics of European Integration: From the Single Act to the Maastricht Treaty', in S.Martin, The Construction of Europe (Dordrecht: Kluwer Academic Publ.), pp.91-112.

Dehousse, R., et al., (1992) Europe after 1992: New Regulatory Strategies (EUI Working Paper LAW No. 92/31) (Florence: European University Institute). 
Dehousse, R., Joerges, C., Majone, G., and Snyder, F., (1992) Europe after 1992: New Regulatory Strategies (EUI Working Paper LAW No. 92/31) (Florence: European University Institute).

Deloche-Gaudez, F., (2007) Traité réformateur : le veto, les peuples et les mots. Retrieved October 26, 2007, from http://www.portedeurope.org/IMG/pdf/euros_du_villagefin al1810.pdf

Deloche-Gaudez, F. (2005) "Le Secretariat de la convention europeenne: un acteur influent". In : Guy Milton et al.. The European constitution: its origins, negotiation and meaning. ( London: John Harper Publishing).

Dessler, D., (1989) 'What's at stake in the agent-structure debate?', International Organization, Vol.43, No.3, pp.441-473.

Dinan, D., (1997) 'The Commission and Enlargement', in J. Redmond and G. Rosenthal (eds), The Expanding European Union: Past, Present, Future (Boulder, CO: Lynne Rienner), pp. 17-40.

Dinan, D., (2000) 'The European Commission and the Intergovernmental Conference', in N. Nugent (ed.), At the Heart of the Union: Studies of the European Commission, 2nd edn (Basingstoke: Macmillan), pp. 250-69.

Dinan, D. and Vanhoonacker, S., (2000) 'IGC 2000 Watch', ECSA Review Vol.13, No.3, pp. 1-9.

Docksey, C. and Williams, K., (1994) 'The Commission and the Execution of Community Policy', in D. Edwards and G. Spence (eds), The European Commission (London: Longman), pp. 117-45.

Donnelly, B., (2007) 'Reform Treaty: small step or giant leap?' Federal Trust Policy Commentary.

Donnelly, M., and E.Ritchie, M., (1994) 'The College of Commissioners and their Cabinets', in G.Edwards and 
D.Spence (ed.), The European Commission (London: Longman), pp.31-61.

Donnelly, M., (1993) 'The Structure of the Commission and the Policy-Formation Process', in S.Mazey and J.Richardson, Lobbying in the European Coomunity (Oxford: OUP), pp.74-81.

Downs, A., (1967) Inside Bureaucracy (Washington: Little, Brown and Co.).

Drake, H. (1995) 'Political leadership and European Integration: The Case of Jacques Delors', West European Politics, Vol.18, No.1, pp.140-160.

Duff, A., (2007) True Guide to the Treaty of Lisbon. Retrieved December 11, 2007, from http://www.alde.eu/fileadmin/files/Download/True-GuideNEW.pdf.

Duke, S., (2005) The Linchpin COPS: Assessing the workings and institutional relations of the Political and Security Committee, paper prepared for the European Institute for Public Administration (Maastricht).

Edwards, G. and Spence, S., (1994) The European Commission (London: Longman).

Egeberg, M., (1995) 'Bureaucrats as Public Policy-Makers and their Self-Interest', Journal of Theoretical Politics Vol.7, No.2, pp.157-167.

Egeberg, M., (1999) 'Transcending Intergovernmentalism: Identity and Role Perceptions of National Officials in EU Decision-making', Journal of European Public Policy Vol.6, No.3, pp.456-474.

Egeberg, M., (1995) Organisation and Nationality in the European Commission Services, paper prepared for the ECPR Joint Session of Workshops, Bordeaux.

Ehlermann, D., (1994) 'Zur Wettbewerbspolitik und zum Wettbewerbsrecht der Europäischen Union', in E.Kantzenbach et al., Hamburger Jahrbuch für Wirtschafts- 
und Gesellschaftspolitik (Tübingen: J.C.B.Mohr), pp.255-280.

Eichener, V., (1992) Social Dumping or Innovative Regulation? (EUI Working Paper SPS No. 92/28), paper prepared for the European University Institute, Florence.

Ekengren, M., (2002) The Time of European Governance (Manchester: Manchester University Press).

Eriksen, E.O., Fossum, J.E., and Menéndez, A.J. (eds) (2004) Developing a Constitution for Europe (London and New York: Routledge).

Erk, J., (2007) Real Constitution, Formal Constitution and Democracy in the European Union, Journal of Common Market Studies, Vol.45, No.3, pp. 633- 652.

European Commission (1992a) Increased Transparency in the work of the Commission SEC(92) 2274 final (Brussels).

European Commission (1992b) An Open and Structured Dialogue between the Commission and Special Interest Groups SEC(92) 2272 final (Brussels).

European Commission (1993) Openness in the Community:

Communications to the Council, the Parliament and the Economic and Social Committee COM(93) 258 final (Brussels).

European Commission (1994) Report to the European Council on the Application of the Subsidiarity Principle, COM (94) 533 final (Brussels).

European Commission (1999a) Communication from Neil Kinnock to the European Commission: Some Strategic Reform Issues (SEC (99) 1917/2) (Brussels).

European Commission (1999b) Designing Tomorrow's Commission: A Review of the Commission's Organisation and Operation (Brussels).

European Commission (2000) Adapting the institutions to make a success of enlargement (COM(2000) 034) (Brussels). 
European Commission (2000) Reforming the Commission, White Paper (Brussels).

European Parliament (2000) Resolution on the outcome of the European Council on 7-11 December 2000 in Nice, 14 December 2000.

European Policy Centre (EPC) (2007a) Post-Summit Analysis: Over and done with - at last . Retrieved on October 22, 2007, from http://www.epc.eu/en/pub.asp?TYP=ER\&LV=294\&see=y\& $\mathrm{t}=15 \& \mathrm{PG}=\mathrm{ER} / \mathrm{EN} /$ detail $\& \mathrm{l}=\& \mathrm{AI}=749$

European Policy Centre (EPC) (2007b) Report - The Treaty of Lisbon - implementing the institutional innovations. Retrieved on November 29, 2007, from http://www.epc.eu/en/er.asp?TYP=ER\&LV=293\&see=y\&t $=2 \& \mathrm{PG}=\mathrm{ER} / \mathrm{EN} /$ detail $\& \mathrm{l}=\& \mathrm{AI}=760$

European Voice (1996) 'Secrecy report - sorry, it's secret', 3 October 1996.

European Voice (1997) 'Senior official criticised over recruitment', 20 March 1997.

European Voice (1999a) 'Staff dispute risks delaying EU reform', 1 April 1999.

European Voice (1999b) 'Commission Needs a "Cultural Revolution”", 29 July 1999, p. 5.

European Voice (1999c) 'Master of his brief', 9 December 1999

European Voice (2000a), 'De Boissieu's surprise intervention', 30 March 2000

European Voice (2000b) 'Top official attacks the way governments conduct EU business', 6 April 2000.

European Voice (2000c) 'Shake-up of staff causes friction in institutions', 12 October 2000.

European Voice (2000d) 'A calculated summit for Chirac's man', 21 December 2000. 
European Voice (2001a) 'Berlin backs steering body for convention', 14 March 2001, p.9.

European Voice (2001b) 'Leaked letter exposes 'split' in Kinnock camp', 29 March 2001, p.1.

European Voice (2001c) 'German MEPs will not ratify Nice until Laeken bears fruit', 25 April 2001, p.8.

European Voice (2001d) 'MEPs support call for a European Union constitution', 16 May 2001, p.6.

European Voice (2001e) 'Top officials wound Prodi in Delors think-tank attack', 17 May 2001, p.1.

European Voice (2001f) 'MEP's set for Court fight over 'illegal' Council security rules', 5 July 2001.

European Voice (2001g) 'Reform chief set for 'golden handshake", 12 July 2001, p.1.

European Voice (2002) 'Closing time may be near for the presidency merry-go-round', 24 January 2002.

Evans, P., et al., (1985) Bringing the State Back In (Cambridge: Cambridge UP).

Evers, T., (1994) 'Supranationale Staatlichkeit am Beispiel der Europäischen Union: Civitas civitatum oder Monstrum?', Leviathan, Vol.22, No.1, pp.115-134.

Falkner, G., (2002a) 'How Intergovernmental are Intergovernmental Conferences? The Maastricht Treaty Reform and the Europeanisation of Social Policy', Journal of European Public Policy, Vol.9, No.1, pp. 98-119.

Falkner, G., (2002b) 'Introduction', Journal of European Public Policy, Vol.9, No.1.

Farrell, H. and Héritier, A., (2003) 'Formal and Informal Institutions Under Codecision: Continuous ConstitutionBuilding in Europe', Governance: An International Journal of Policy, Administration, and Institutions, Vol. 16, No. 4, pp. 577-600. 
Farrell, H. and Héritier, A., (2004) 'Interorganizational Negotiation and Intraorganizational Power In Shared Decision Making' in Comparative Political Studies, Vol.37, No.10, pp. 1184-1212.

Financial Times (2000) 'EU Prepares to Streamline its Failing Diplomacy", 4 September 2000, p. 2.

Financial Times (2000) 'Prodi’s Progress', 18 January 2000, p. 9.

Financial Times (2002) 'Solana attacks decision-makers', 12 March 2002

Financial Times 'Blair and Schröder join forces on EU reform', 24 February 2002.

Flora, P., (1981) 'Stein Rokkan's Makro-Modell der Politischen Entwicklung Europas: Ein Rekonstruktionsversuch', Kölner Zeitschrift für Soziologie und Sozialpsychologie, Vol.33, No.3, pp.397-436.

Fossum, J.E., (2004) 'Still a Union of Deep Diversity? The Convention and the Constitution for Europe' in E.O. Eriksen, J.E. Fossum and A.J. Menéndez (eds). Developing a Constitution for Europe (London and New York: Routledge), pp.226-247.

Fouilleux, E., Maillard, J.de and Smith, A (2001) The Role of Council Working Groups in the Production of European Problems and Policies, paper prepared for the EIPA workshop 'Governance by Committee, the Role of Committees in European Policy-making and Policyimplementation, Brussels, 6 March 2001.

Friedland, R. and Alford, R., (1991) 'Bringing Society Back In: Symbols, Practices and Institutional Contradictions', in M.Powell and P.DiMaggio, The New Institutionalism in Organizational Analysis (Chicago: Chicago UP), pp.232-267.

Fuchs, G. (1995) 'The European Commission as a Corporate Actor? European Telecommunications Policy After Maastricht', in S. Rhodes and C. Mazey (eds), The State of 
the European Union, Vol.3 (Boulder, CO: Lynne Rienner), pp. 413-30.

Galloway, D., (2001) The Treaty of Nice and Beyond. Realities and Illusions of Power in the EU (Sheffield: Sheffield Academic Press).

García, S., (1993) European Identity and the Search for Legitimacy (London: Pinter).

Garret, G., (1992) 'International cooperation and institutional choice: the European Community's internal market', International Organiszation, Vol.46, No.2, pp.533-560.

Garret, G., (1995) 'The politics of legal integration in the European Union', International Organization, Vol.49, No.1, pp.171-181.

Gebhardt, W., (1992) 'Individualisierung, Pluralisierung und institutioneller Wandel. Für eine "kritische" Theorie der Institutionen', Der Staat, Vol.31, No.3, pp.347-366.

General Secretariat of the Council of the EU (2000) Basic Texts on Transparency concerning the activities of the Council of the EU (Brussels).

General Secretariat of the Council of the EU Basic Texts on Transparency concerning the activities of the Council of the $E U$ (Brussels: 2000).

George, S., (1995) The European Commission: Opportunities Seized; Problems Unresolved, paper prepared for the First UACES Research Conference, Birmingham.

Giddens, A., (1977) Studies in Social and Political Theory (London: Hutchinson).

Giddens, A., (1983) 'Comments on the Theory of Structuration', Journal for the Theory of Social Behaviour, Vol.13, No.1, pp.75-80.

Giddens, A., (1984) The Constitution of Society (Cambridge: Polity Press). 
Goetz , K.H., (2006) Temporality and the European Administrative Space, Paper presented at the CONNEX Thematic Conference 'Towards a European Administrative Space', London, 16-18 November 2006.

Grant, C., (1994) Delors: Inside the House that Jacques Built (London: Brealey).

Gray, A. and Stubb, M., (2001) 'The Treaty of Nice', in W.Wessels and Wiessala (ed.), JCMS Annual Review (Oxford: Blackwell).

Gray, M, (2002) 'Negotiating the Treaty of Amsterdam: The role and influence of the European Commission', in F.Laursen (ed.), The Treaty of Amsterdam (Odense: Odense University Press).

Gray, M., (2001) 'Negotiating the Treaty of Amsterdam: The role and influence of the European Commission', in F.Laursen (ed.), The Treaty of Amsterdam (Odense: Odense University Press).

Gray, M. and Stubb, A., (2002) 'The Treaty of Nice', in W.Wessels and W.Wiessala (ed.), JCMS Annual Review (Oxford: Blackwell).

Gray, M. and Stubb, A., (2001), 'The Treaty of Nice', in W.Wessels and G.Wiessala (ed.), JCMS Annual Review (Oxford: Blackwell).

Grendstad, G. and Selle, P., (1995) 'Cultural Theory and the New Institutionalism', Journal of Theoretical Politics, Vol.7, No.1, pp.5-27.

Greve, M. and K.E.Jørgensen, (2002) 'Treaty Reform as Constitutional Politics', Journal of European Public Policy, Vol.9, No.1, pp. 54-75.

Grey, S., (2000) Tackling Fraud and Mismanagement in the European Union, paper prepared for the Centre for European Reform, London.

Große Hüttmann, M., (2005) Reformen durch Regierungskonferenzen: Struktur und Wandel von 
Vertragsänderungen in der Europäischen Union (BadenBaden: Nomos Verlag).

The Guardian 'Security lapses in Brussels HQ cast doubt on EU defence plans', 19 February 2000

Haaland Matlary, J., (1997) 'Democratic Legitimacy and the Role of the Commission', in P. Koslowski and A. Foellesdal (eds), Democracy and the EU (Berlin: Springer).

Haaland Matláry, J., (1995) 'New Forms of Governance in Europe? The Decline of the State as the Source of Political Legitimacy', Cooperation and Conflict, Vol.30, No.2, pp.99-125.

Hagemann, S., (2007) EPC Commentary: Ratifying the Lisbon Treaty: what happens now?

Hammarskjöld, D., (1961) The International Civil Service in Law and Fact (Oxford: Clarendon Press).

Hayes-Renshaw, F. and Wallace, H., (1997) The Council of Ministers (London: Macmillan).

Heisenberg, D., (2005) 'The institution of 'consensus' in the European Union: Formal versus informal decision-making in the Council', European Journal of Political Research, Vol.44, No.1, pp.65-90

Héritier, A., (1997) 'Policy-making by subterfuge: interest accommodation, innovation and substitute democratic legitimation in Europe: perspectives from distinct policy areas', Journal of European Public Policy, Vol.4, No.2, pp. 171-189.

Herz, J., (1957) 'Rise and Demise of the Territorial State', World Politics, Vol.9, No.4, pp.473-493.

Herz, J., (1968) 'The Territorial State Revisited - Reflections on the Future of the Nation State', Polity, Vol.1, No.1, pp.1134.

Hix, S., (1995) 'Parties at the European Level as an Alternative Source of Legitimacy: The Party Federations and the EU 
Socio-Economic Agenda', Journal of Common Market Studies Vol.33, No.4, pp.527-54.

Hix, S., (1999) The Political System of the European Union (Basingstoke: Macmillan).

Hix, S., (2000) 'Executive Selection in the European Union: Does the Commission President Investiture Procedure Reduce the Democratic Deficit', in K. Neunreithner and A. Wiener (eds), European Integration after Amsterdam (London: Routledge), pp. 95-111.

Hoffmann, S., (1966) 'Obstinate or Obsolete? The Fate of the Nation-State and the Case of Western Europe', Daedalus, Vol.95, No.4, pp.862-915.

Hoffmann, S., (1982) 'Reflections on the Nation-State in Western Europe Today', Journal of Common Market Studies, No.1, pp.21-56.

Hollis, M., and Smith, S., (1991) 'Beware of gurus: structure and action in international relations', Review of Intrenational Studies, Vol.17, No.4, pp.393-410.

Hollis, M. and Smith, S., (1991) Explaining and Understanding International Relations (Oxford: Clarendon).

Hollis, M. and Smith, S., (1992) 'Structure and action: further comment', Review of Intrenational Studies, Vol.18, No.2, pp.187-188.

Holm, U., (1997) 'The French Garden is no longer what is has been', in K.E.Jørgensen (ed.), Reflectivist Approaches to European Integration (London: Macmillan), pp.128-145.

Holm, U., (1997) 'The French Garden is no longer what is has been', in K.E.Jørgensen, Reflectivist Approaches to European Integration (London: Macmillan)

Holman, O., (2001) 'The Enlargement of the European Union towards Central and Eastern Europe: The Role of Supranational and Transnational Actors', in A.Bieler and A.Morton (eds), Social Forces in the Making of the New Europe (Basingstoke: Palgrave), pp.161-184. 
Hooghe, L., (2000) 'A House with Differing Views: The European Commission and Cohesion Policy', in N. Nugent (ed.), At the Heart of the Union: Studies of the European Commission, 2nd edn (Basingstoke: Macmillan), pp. 91110 .

Hooghe, L., (ed.) (1996) Cohesion Policy and European Integration: Building Multilevel Governance (Oxford: Oxford University Press).

Jachtenfuchs, J., (1995) 'Theoretical Approaches to European Governance', European Law Journal, Vol.1, No.2, pp. 115-133.

Jacobs, F., (1999) Nominations and Appointments: An Evolving EU Model, paper prepared for the Biennial ECSA Conference, Pittsburgh.

Jacobs, F., (1995) The European Parliament's Role in Nominating the Members of the Commission: First Steps Towards Parliamentary Government of US Senate-Type Confirmation Hearings?, paper prepared for the Fourth Biennial International ECSA Conference, Charleston, SC.

Jørgensen, K.E., (1997) Reflective Approaches to European Governance (London: Macmillan).

Jørgensen, K.E., (1995) 'European Leviathans and Beyond: Differentiating Layers of International Transformation', in N.A.Soerensen (ed.), European Identites: Cultural Diversity and European Integration since 1700 (Odense: Odense University Press).

Jørgensen, K.E., (1996) 'Basic International Institutions, PseudoInstituions and Institutions called States', review article, Cooperation and Conflict.

Joerges, C., (1994) Die Beurteilung der Sicherheit technischer Konsumgüter und der Gesundheitsrisiken von Lebensmitteln in der Praxis des europäischen Ausschußwesens ("Komitologie") ZERP Discussion Paper (Bremen: Zentrum für Europäische Rechtspolitik). 
Joerges, C., (1996) 'Political Science and the Role of Law in the Process of European Integration', European Law Journal, Vol.2, No.1, pp.105-135.

Kassim, H. and Dimitrakopoulos, D., (2005) The European Commission's Role in the European Convention Paper presented at the ECPR Joint Session of Workshops, Granada.

Kassim, H. and Dimitrakopoulos, D., (2007) The European Commission and the future of Europe, Journal of European Public Policy, Vol. 14, No. 8, pp. 1249 - 1270.

Kenis, P. and Schneider, V., (1987) 'The EC as an International Corporate Actor: Two Case Studies in Economic Diplomacy', European Journal of Political Research Vol.15, No.4, pp.437-57.

Keohane, R. and Hoffmann, S., (1990) 'Conclusion: Community Politics and Institutional Change', in W.Wallace (ed.), The Dynamics of European Integration (London: Pinter), pp.276-300.

Kleine, M., (2007) Leadership in the European Convention, Journal of European Public Policy, Vol.14, No.8, pp. 1227 -1248 .

Koelble, T., (27) 'The New Insitutionalism in Political Science and Sociology', Comparative Politics, Vol.2, No.1995, pp.231-244.

Koelble, T., (27) 'The New Insitutionalism in Political Science and Sociology', Comparative Politics, Vol.2, No.1995, pp.231-244.

Kohler-Koch, B., (1996) 'Catching up with change: the transformation of governance in the European Union', Journal of European Public Policy, Vol.3, No.3, pp.359380 .

Kohler-Koch, B., (1996) 'Regionen als Handlungseinheiten in der Eurooäischen Politik', Welttrends, Vol.11, No.1, pp.7-35. 
Kurpas, S., Incerti, M. and Schonlau J. (2005) What Prospects for the European Constitutional Treaty? Monitoring the Ratification Debates, Results of an EPIN Survey of National Experts. Working Paper No.12/January 2005

Laffan, B., (1997) 'From Policy-Entrepreneur to Policy-Manager: The Challenge Facing the European Commission', Journal of European Public Policy Vol.4, No.3, pp.422-38.

Laffan, B., (2000) The Nice Treaty. The Irish vote. An analysis of the Irish "No", paper prepared for Fondation Notre Europe, Paris.

Lenaerts, K., (1991) 'Some Reflections on the Separation of Powers in the European Community', Common Market Law Review, Vol.28, No.1, pp.11-35.

Levy, R., (2000) 'Managing the Managers: The Commission's Role in the Implementation of Spending Programmes', in N. Nugent (ed.), At the Heart of the Union: Studies of the European Commission, 2nd edn (Basingstoke: Macmillan), pp. 206-29.

Lewis, J., (1998) 'Is the Hard Bargaining Image of the Council Misleading? The Committee of Permanent Representatives and the Local Election Directive', Journal of Common Market Studies Vol.36, No.4, pp.479-504.

Lewis, J., (2000) 'The Methods of Community in EU Decisionmaking and Adminstrative Rivalry in the Council's Infrastructure', Journal of European Public Policy Vol.7, No.2, pp.261-89.

Linz, J., (1993) 'State Building and Nation Building', European Review, Vol.1, No.4, pp.355-370.

Lipsius, J., (1995) 'The 1996 IGC', European Law Review Vol.20, No.3, pp.235-57.

Lipsius, J., (1995) 'The 1996 Intergovernmental Conference', European Law Review, Vol.3, pp.235-253.

Ludlow, P., (1991) 'The European Commission', in R.O.Keohane and S.Hoffmann, The New European Community - 
Decisionmaking and Institutional Change (Boulder, Co.: Westview), pp.88-132.

Macdonald, M., (2000) 'Identities in the European Commission', in N. Nugent (ed.), At the Heart of the Union: Studies of the European Commission, 2nd edn (Basingstoke: Macmillan), pp. 51-72.

MacMullen, A., (2000) 'European Commissioners: National Routes to a European Elite', in N. Nugent (ed.), At the Heart of the Union: Studies of the European Commission, 2nd edn (Basingstoke: Macmillan), pp. 28-50.

Magnette, P., (2004) 'Deliberation or Bargaining? Coping with Constitutional Conflicts in the Convention on the Future of Europe' in E.O. Eriksen, J.E. Fossum and A.J. Menéndez (eds.). Developing a Constitution for Europe (London and New York: Routledge), pp.207-225.

Majone, G., (1993) 'The European Community between Social Policy and Social Regulation', Journal of Common Market Studies, Vol.31, No.2, pp.153-170.

Majone, G., (1994) Independence v. Accountability? Non-Majoritarian Institutions and Democratic Government in Europe (EUI Working Paper SPS No. 94/3) (Florence: European University Institute).

Mak, J., (2004) 'Informality as an Asset? The Case of EMU', in T. Christiansen and S.Piattoni (ed.), Informal Governance in the European Union (Cheltenham, UK: Edward Elgar).

Mancini, F., (1989) 'The Making of a Constitution for Europe', Common Market Law Review, Vol.26, No.4, pp.595-614.

Mann, M., (1993) 'Nation-State in Europe and Other Continents: Diversifying, Developing, Not Dying', Daedalus, Vol.122, No.3, pp.115-140.

March, J.G. and Olsen, J.P., (1984) 'The New Institutionalism: Organizational Factors in Political Life', American Political Science Review, Vol.78, pp.734-739. 
March, J.G., and Olsen, J.P., (1984) 'The New Institutionalism: Organizational Factors in Political Life', American Political Science Review, Vol.78, pp.734-739.

Marks, G., (1992) 'Structural Policy in the European Community', in A.Sbragia, Euro-Politics (Washington, D.C.: The Brookings Institution), pp.191-224.

Marks, G., (1993) 'Structural Policy and Multilevel Governance in the EC', in A.W.Cafruny and G.G.Rosenthal (ed.), The State of the European Community (Boulder, Co.: Lynne Rienner),

Marks, G., et al. (1996) 'European Integration from the 1980s: State-Centric v. Multilevel Governance', Journal of Common Market Studies, Vol.34, No.3, pp.341-379.

Marks, G., Nielsen, F., Ray, L. and Salk, J. E., (1996) 'Competencies, Cracks, and Conflicts: Regional Mobilization in the European Union', Comparative Political Studies Vol.29, No.2, pp.164-91.

Marques, A., (1994) 'Regionalbeihilfen und Kohäsion. Tragweite und Grenzen gemeinwirtschaftlicher Maßnahmen', Raumforschung und Raumordnung, Vol.52, No.2, pp.127-137.

Mattli, W. and Slaugther, A.M., (1995) 'Law and politics in the European Union: a reply to Garret', International Organization, Vol.49, No.1, pp.183-190.

Mazey, S., (1992) 'Conception and Evolution of the High Authority's Administrative Services (1952-1956): From Supranational Principles to Multinational Practices', in E. Heyen with G. Melis, J.-L. Mestre, V. Wright and B. Wunder (eds), Jahrbuch der Europäischen Verwaltungsgeschichte, 4: Die Anfänge der Verwaltung der Europäischen Gemeinschaft (Baden-Baden: Nomos), pp. 31-47.

Mazey, S., (1995) 'The Development of EU Equality Policies: Bureaucratic Expansion on behalf of Women?', Public Administration Vol.73, No.4, pp..591-610. 
Mazey, S. and Richardson, J., (1994) 'The Commission and the Lobby', in D. Edwards and G. Spence (eds), The European Commission (London: Longman), pp. 169-201.

Mazzucelli, C., (1997) France and Germany at Maastricht (New York: Garland Publishing, Inc).

McGowan, L., (2000) 'Safeguarding the Economic Constitution: The Commission and Competition Policy', in N. Nugent (ed.), At the Heart of the Union: Studies of the European Commission, 2nd edn (Basingstoke: Macmillan), pp. 14769.

McGowan, L. and Wilks, S., (1995) 'The first supranational policy of the European Union: Competition policy', European Journal of Political Research, Vol.28, No.2, pp.141-169.

Mearsheimer, J., (1995) 'The False Promise of International Institutions', International Security, Vol.19, No.3, pp.5-19.

Mendrinou, M., (1996) 'Non-compliance and the European Commission's role in integration', Journal of European Public Policy, Vol.3, No.1, pp.1-22.

Metcalfe, L., (2001) 'Reforming the Commission', Journal of Common Market Studies, Vol.38, No.5, pp.817-842.

Meunier, S. and Nicolaides, K., (1999) 'Who Speaks for Europe? The Delegation of Trade Authority in the EU', Journal of Common Market Studies Vol.37, No.3, pp.477-501.

Milton, G. and Keller-Noëllet, J. with Bartol-Saurel, A. (2005) The European Constitution - its origins, negotiation and meaning (London: John Harper Publishing).

Milward, A., (ed.) (1992) The European rescue of the nation-state (London: Routledge).

Monar, J., (1997) 'The Finances of the Union's Intergovernmental Pillars: Tortuous Experiments with the Community Budget', Journal of Common Market Studies, 1997, Vol. 35, No.1, pp. 57-78. 
Moravcsik, A., (1999) 'A New Statecraft? Supranational Entrepreneurs and International Cooperation', International Organization Vol.53, No.2, pp.267-306.

Moravcsik, A. and K.Nicolaïdes, (1999) 'Explaining the Treaty of Amsterdam: Interests, Influence, Institutions', Journal of Common Market Studies, Vol.37, No.1, pp.59-86.

Moravcsik, A., (1991) 'Negotiating the Single Act: National Interests and Conventional Statecraft in the European Community', International Organisation, Vol.45, No.1, pp.19-46.

Moravcsik, A., (1993) 'Preferences and Power in the European Community: A Liberal Intergovernmentalist Approach', Journal of Common Market Studies, Vol.31, No.4, pp.473523.

Moravcsik, A., (1994) Why the European Community Strengthens the State: Domestic Politics and International Cooperation, paper prepared for the Conference of Europeanists, Chicago.

Münch, R., (1993) Das Projekt Europa. Zwischen Nationalstaat, regionaler Autnomie und Weltgesellschaft (Frankfurt/M.: Suhrkamp).

Neumann, I., (1992) Regions in International Relations Theory The Case for a Region-Building Approach (NUPI Research Report No.162) (Oslo: Norwegian Institute of International Affairs).

Neumann, I. and Welsh, J., (1991) "The "Other" in European identity: an addendum to the literature on international society', Review of International Studies, Vol.17, No.4, pp.327-345.

Nicolaïdis, K., (2004) 'We the Peoples of Europe...', Foreign Affairs, Vol.83, No.6, pp. 97-110.

Norman, P., (2005) The Accidental Constitution: The Making of Europe's Constitutional Treaty (Brussels: EuroComment). 
Nugent, N., ( 2000) At the Heart of the Union : Studies of the European Commission 2nd edn (London: Macmillan).

Nugent, N., (2001) The European Commission, Basingstoke: Palgrave.

Nugent, N., (1995a) 'The Leadership Capacity of the European Commission', Journal of European Public Policy, Vol.2, No.4, pp.603-623.

Nugent, N., (1995b) The Government and Politics of the European Union (London: Macmillan).

Nuttall, S., (1996) 'The Commission: The Struggle for Legitimacy', in C. Hill (ed.), The Actors in Europe's Foreign Policy (London: Routledge), pp. 130-47.

Olsen, P.J., (1995) The Changing Political Organization of Europe (Working Paper No.17) (Oslo: ARENA).

Onuf, N., (1990) World of Our Making: Rules and Rule in Social Theory and International Relations University of South Carolina Press).

Onuf, N., (1991) 'Sovereignty: Outline of a Conceptual History', Alternatives, Vol.16, No.4, pp.425-446.

Paasi, A., (1986) 'The institutionalization of regions: a theoretical framework for understanding the emergence of regions and constitution of regional identity', Fennia, Vol.164, No.1, pp.105-146.

Page, E., (1990) 'The Political Origins of Self-Government and Bureaucracy: Otto Hintze's Conceptual Map of Europe', Political Studies, Vol.38, No.1, pp.39-55.

Page, E. and Wouters, L., (1994) 'Bureaucratic Politics and Political Leadership in Brussels', Public Administration Vol.72, No.3, pp.445-459.

Palmer, J., (2007) "Perspectives for the European Union after the Lisbon European Council" Federal Trust Policy Commentary. Retrieved in October 2007 from 
http://www.fedtrust.co.uk/uploads/Commentary2_October -07.pdf

Party of European Socialists, (2000) PES Summit in Biarritz, Press release, 3 October 2000.

Peters, G., (1992) 'Bureaucratic Politics in the European Community', in A. Sbragia (ed.), Euro- politics: Institutions and Policymaking in the 'New' European Community (Washington, DC: Brookings Institution).

Peters, G., (2000) 'The Commission and Implementation in the European Union', in N. Nugent (ed.), At the Heart of the Union: Studies of the European Commission, 2nd edn (Basingstoke: Macmillan), pp. 190-205.

Peters, G., (1992) 'Bureaucratic Politics in the European Community', in A. Sbragia (ed.), Euro- politics: Institutions and Policymaking in the 'New' European Community (Washington, DC: Brookings Institution).

Peterson, J., (1999) 'The Santer Era: The European Commission in Normative, Historical and Theoretical Perspective', Journal of European Public Policy, Vol.6, No.1, pp.46-65.

Peterson, J., (2000) 'Romano Prodi: Another Delors?', ECSA Review, Vol.13, No.1, pp.1-8.

Peterson, J., (1995) 'Decision-making in the European Union: towards a framework for analysis', Journal of European Public Policy, Vol.2, No.1, pp.69-93.

Petite, M., (2000) 'The European Commission and the IGC', in E.Best, M.Gray, and A.Stubb (ed.), Rethinking the European Union (Maastricht: European Institute of Public Administration).

Philip Morris Institute for Public Policy Research, (1995) What future for the European Commission (Brussels).

Philpott, D., (1995) 'Sovereignty: An Introduction and Brief History', Journal of International Affairs, Vol.48, No.2, pp. 353-368. 
Pierson, P., (1996) 'The Path to European Integration - A Historical Institutionalist Analysis', Comparative Political Studies, Vol.29, No.2, pp.123-163.

Poggi, G., (1990) The State, Its Nature, Developments and Prospects (Stanford: Stanford UP).

Pollack, M., (1994) 'Creeping Competence: The Expanding Agenda of the European Community', Journal of Public Policy Vol.14, No.2, pp.95-145.

Pollit, C., (1988) 'Bureaucracy and Democracy', in D. Held and C. Pollit (eds), New Forms of Democracy (London: Sage), pp. $158-191$.

Powell, M. and DiMaggio, P., (1991) The New Institutionalism in Organizational Analysis (Chicago: Chicago UP).

Presidency of the European Union (1999) Presidency Conclusions of the Helsinki European Council (Brussels).

Presidency of the European Union (2000) Presidency Report on Strengthening the Common European Security and Defence Policy to the Lisbon European Council (Brussels).

Presidency of the European Union (2007) Declaration on the occasion of the fiftieth anniversary of the signature of the Treaties of Rome (Berlin)

Prodi, R., (2001) 'For a strong Europe, with a grand design and the means of action', speech held on 29 May 2001 at the Institut d'Etudes Politiques (Paris).

Puetter, U., (2007) Intervening from outside: the role of EU finance ministers in the constitutional politics, Journal of European Public Policy, Vol. 14, No. 8, pp.1293 - 1310.

Rasmussen, H., (1988) 'Between Self-Restraint and Activism: A Judicial Policy for the European Court', European Law Review, Vol.13, No.1, pp.28-38.

Reh, C., (2007a) Pre-cooking the European Constitution? The role of government representatives in EU reform, Journal of European Public Policy, Vol.14, No.8, pp.1186 - 1207. 
Reh, C., (2007) The Politics of Preparation: Delegated Decisions, Arguing and Constitutional Choice in Europe, $\mathrm{PhD}$ Thesis defended at the European University Institute, Florence, Italy

Rhinard, M. and Vaccari, B., (2005) 'The Study of the European Commission', Journal of European Public Policy, Vol.12, No.2, pp. 387-395.

Richardson, J.J., (1982) Policy Styles in Western Europe (London: Allen \& Unwin).

Richardson, J.J., (1995) 'Actor-Based Models of National and EC Policy-Making: Policy Communities, Issue Networks and Advocacy Coalitions', in H.Kassim and A.Menon, The EU and National Industrial Policy Policy (London: Routledge).

Richardson, J.J., (1996) 'Policy-making in the EU: Interests, ideas and garbage cans of primeval soup', in J.J.Richardson (ed.), European Union: Power and Policy-making (London: Routledge).

Rokkan, S., (1973) 'Cities, States and Nations: A Dimensional Model for the Study of Contrasts in Development', in S.N.Eisenstadt and S.Rokkan (ed.), Building States and Nations (London: Sage), pp.73-97.

Ross, G., (1994) Jacques Delors and European Integration (Cambridge: Polity Press).

Ruggie, J.G., (1989) 'International Structure and International Transformation: Space, Time and Method', in E.O.Czempiel and J.N.Rosenau (ed.), Global Changes and Theoretical Challenges (Lexington, Ma.: Lexington Books), pp.21-36.

Sasse, C., (1975) Regierungen, Parlamente, Ministerrat: Entscheidungsprozesse in der Europäischen Gemeinschaft (Bonn: Europa Union Verlag).

Scharpf, F.W., (1994) Optionen des Föderalismus in Deutschland und Europa (Frankfurt/M.: Campus). 
Scheinmann, L., (1966) 'Some Preliminary Notes on Bureaucratic Relationships in the European Economic Community', International Organisation Vol.20, No.4, pp.750-773.

Schink, G., (1992) 'Kompetenzerweiterung im Handlungsystem der Europäischen Gemeinschaft: Eigendynamik und "policy-entrepreneure", unpublished Ph.D. thesis, Florence.

Schmidt, S., (2000) 'Only an Agenda-Setter?', European Union Politics Vol.1, No.1, pp.37-61.

Schmitter, P., (1992) 'Representation and the Future Euro-Polity', Staatswissenschaften und Staatspraxis, Vol.2, No.3, pp.379-405.

Secretary-General of the Council of Ministers (1999) Operation of the Council with an Enlarged Union in Prospect (Brussels).

Shaw, J., (2000), 'Process and Constitutional Discourse in the European Union', in C. Harvey, J. Morison and J. Shaw (eds), Voices, Spaces, and Processes in Constitutionalism (Oxford: Blackwell), pp.4-37.

Sherrington, P., (2000) The Council of Ministers: Political Authority in the European Union (London: Pinter).

Smith, A., (1993) 'A Europe of Nations - or the Nation of Europe?', Journal of Peace Research, Vol.30, No.2, pp.129-135.

Smith, A., Fouilleux, E. and de Maillard, J, (2005) ' Technical Or Political? The Working Groups of the EU Council of Ministers, Journal of European Public Policy, Vol.12, No.4, pp.609-623.

Smith, B.P.G., (2002) Constitution-Building in the European Union: The Process of Treaty Reforms (The Hague: Kluwer).

Smith, M., (1994) 'The Commission and external relations', in G.Edwards and D.Spence (ed.), The European Commission (London: Longman), pp.249-286. 
Snyder, F., (1993) Soft Law and Institutional Practice in the European Community (EUI Working Paper LAW No. 93/5) (Florence: European University Institute).

Snyder, F., (1990) New Directions in European Community Law (London: Weidenfled and Nicolson).

Somsen, H., (1995) 'Subsidiarity and the Enforcement of EC Environmental Law', in U.Collier et.al.(eds), Subsidiarity and Shared Responsibilities: New Challenges for EU Environmental Studies (London: Routledge).

Sozialdemokratische Partei Deutschlands, (2001), Leitantrag 'Verantwortung für Europa' für den SPD-Bundesparteitag in Nürnberg, 19.11. - 23.11.2001 (Berlin)

Spence, D., (1994) 'Structure, Functions and Procedures in the Commission', in D. Edwards and G. Spence (eds), The European Commission (London: Longman), pp. 97-114.

Spence, D., (2000) 'Plus ca change, plus ca meme chose? Attempting to reform the European Commission', Journal of European Public Policy, Vol.7, No.1, pp.1-25

Stein, E., (1986) 'Uniformity and Diversity in a Divided-Power System: The United States Experience', Washington Law Review, Vol.61, No.4, pp.1081-1092.

Stone, A., (1994) 'The New Constitutional Politics of Europe', Comparative Political Studies, Vol.26, No.4, pp.397-420.

Stone, A. and Sandholtz, W., (1997) 'European integration and supranational governance', Journal of European Public Policy, Vol.4, No.3, pp.1-24.

Stubb, A., (2002) Negotiating Flexibility in the European Union Amsterdam, Nice and Beyond (Basingstoke: Macmillan).

Stubb, A., (1998) Flexible Integration and the Amsterdam Treaty: Negotiating Differentiation in the 1996-97 IGC (London: London School of Economics, $\mathrm{PhD}$ dissertation).

Sverdrup, U., (2000) 'Precedents and present events in the European Union - an institutional perspective on treaty 
reform', in K.-H.Neunreither and A.Wiener (ed.), European Integration after Amsterdam - Institutional Dynamics and Prospects for Democracy (Oxford: OUP), pp.241-265.

Sverdrup, U., (2002) 'An Institutionalist Perspective on Treaty Reform', Journal of European Public Policy, Vol.9, No.1, pp.120-140.

Taylor, P., (1980) The Limits of European Integration (London: Croom Helm).

Thelen, K. and Steinmo, S., (1991) 'Historical institutionalism in comparative politics', in S.Steinmo et al. (ed.), Structuring Politics (Cambridge: Cambridge UP), pp.1-32.

Therborn, G., (1995) European Modernity and Beyond. The Trajectory of European Societes, 1945-2000 (London: Sage).

Therborn, G., (1997) 'Europe in the 21 Century: The World's Scandinavia', Irish Studies in International Affairs, Vol.8, pp.21-34.

Tietje, C., 'The Concept of Coherence in the Treaty on European Union and the Common Foreign and Security Policy', European Foreign Affairs Review, Vol.2, No.2 (1997) pp.211-233, for a discussion of the implications of coherence in the making of CSFP.

Tilly, C., (1975) The Formation of National States in Europe (Princeton, NJ.: Princeton University Press).

Tilly, C., (1984) Big Structures, Large Processes, Huge Comparisons (New York: Russell Sage Foundation).

Tranholm-Mikkelsen, J., (1991) 'Neofunctionalism: Obstiinate or Obsolete? A Reappraisal in the Light of the New Dynamism of the EC', Millennium, Vol.20, No.1, pp.1-22.

Trondal, J., (2001) The 'Parallel Administration' of the European Commission, Paper presented at the ECPRJoint Sessions of Workshops, Grenoble, April 2001. 
Trondal, J., (2001) The 'Parallel Administration' of the European Commission National Officials in European Clothes?, ARENA Working Papers WP 01/25 (Oslo: ARENA, 2001) for a discussion of secondment in the EU.

Tsakatika, M., (2005) 'Claims to Legitimacy: The European Commission between Continuity and Change', Journal of Common Market Studies, Vol.43, No.1, pp.193-220.

Wæver, O., (1990) 'Three Competing Europes: German, French, Russian', International Affairs, Vol.66, No.3, pp.477-493.

Wæver, O., (1991) Territory, Authority and Identity, paper prepared for the 1st General Conference of the European Peace Research Association, Florence.

Wæver, O., (1994) Europe's Three Empires - A Watsonian interpretation of post-wall European security CPCR Working Paper No.8/94) (Copenhagen: Centre for Peace and Conflict Research).

Wæver, O., (1995) 'Identity, Integration and Security. Solving the Sovereignty Puzzle in EU Studies', Journal of International Affairs, Vol.48, No.2, pp.389-431.

Walker, N., (2004) The Legacy of Europe's Constitutional Moment, Constellations, Vol. 11, No. 3, pp. 368-392.

Wallace, H., (1985) 'The Presidency of the Council of Ministers of the European Community: Tasks and Evolution', in C. O. Nuallain (ed.), The Presidency of the European Council of Ministers: Impacts and Implications for National Governments (London: Croom Helm), pp. 1-21.

Wallace, H., (1993) 'A Critical Assessment of the Styles, Strategies and Achievements of the Two Presidencies', in E. Kirchner and A. Tsagkari (eds), The EC Council Presidency: The Dutch and Luxembourg Presidencies (London: UACES), pp. 45-51.

Wallace, H., The Council of Ministers (London: Macmillan, 1997). 
Wallace, W. and Smith, J., (1995) 'Democracy or Technocracy? European Integration and the Problem of Popular Consent', West European Politics Vol.18, No.3, pp.137-157.

Wallace, W., (1983) 'Less than a Federation, More than a Regime: The Community as a Political System', in H.Wallace et al. (ed.), Policy Making in the European Community 2nd edn (Chichester: Wiley), pp.403-436.

Wallström, M., (2007) Debate on the preparation of the European Council and the situation with regard to the revision of the Treatie. Speech held at the European Parliament, Brussels, 7 June 2007.

Wallace, W., (1983) 'Less than a Federation, More than a Regime: The Community as a Political System', in H. Wallace et al., Policy Making in the European Community 2nd Edn (Chichester: Wiley), pp.403-436.

Weiler, J., (1981) 'The Community System: the Dual Character of Supranationalism', Yearbook of European Law, Vol.1, pp.267-305.

Weiler, J., (1991) 'The Transformation of Europe', The Yale Law Journal, Vol.100, No.8, pp.2403-2843.

Weiss, T., (1982) 'International Bureaucracy: the myth and reality of the international civil service', International Affairs, Vol.58, No.2, pp.287-306.

Wendt, A., (1987) 'The agent-structure problem in international relations theory', International Organization, Vol.41, No.3, pp.335-370.

Wendt, A., (1991) 'Bridging the theory/meta-theory gap in international relations', Review of International Studies, Vol.17, No.4, pp.383-392.

Wendt, A., (1992) 'Levels of analysis vs. agents and structures: part III', Review of International Studies, Vol.18, No.2, pp.181-185.

Wessels, W. (1980) Der Europäische Rat (Bonn: Europa Union Verlag). 
Wessels, W., (1990) 'Administrative Interaction', in W. Wallace (ed.), The Dynamics of European Integration (London: Pinter), pp. 229-41.

Wessels, W., (1991) 'The EC Council - The Community's Decisionmaking Center', in R.O.Keohane and S.Hoffmann (ed.), The New European Community - Decisionmaking and Institutional Change (Boulder, Co.: Westview), pp.133-154.

Wessels, W., (1992) 'Staat und (westeuropäische) Integration', in M.Kreile (ed.), Die Integration Europas (Opladen: Westdeutscher Verlag), pp.36-61.

Westlake, M., (1994) The Commission and the Parliament: Partners and Rivals in the European Policy-making Process (London: Butterworth).

Westlake, M., (1995) The Council of the European Union (London: Catermill).

Wilterdink, N., (1990) Where Nations Meet: National Identities in an International Organisation (EUI Working Paper SPS No. 90/3) (Florence: European University Institute).

Wincott, D., (1995) 'Institutional Interaction and European Integration: Towards an Everyday Critique of Liberal Integrovernmentalism', Journal of Common Market Studies, Vol.33, No.4, pp.597-610.

Wind, M., (1996) The Structuration Theory of European Legal and Political Integration, paper prepared for the Workshop on Sociology of European Union Law, Florence.

Wishlade, F., (1993) 'Competition Policy, Cohesion and the Coordination of Regional Aids in the European Community', European Competition Law Review, Vol.14, No.4, pp.143-150.

Wishlade, F., (1994) 'Achieving Coherence in European Community Approaches to Area Designation', Regional Studies, Vol.28, No.1, pp.79-97. 
Wright, S., (2007) A virtual European public sphere? The Futurum discussion forum, Journal of European Public Policy, Vol. 14, No. 8, pp. $1167-1185$.

Woolcock, S., (2000) 'European Trade Policy', in H. Wallace and W. Wallace (eds), Policy-making in the European Union, 4th edn (Oxford: Oxford University Press), pp. 373-400.

Zürn, M., (1996) 'Über den Staat und die Demokratie im europäischen Mehrebenensystem', Politische Vierteljahresschrift, Vol.37, No.1, pp.27-55. 